$$
\text { UNIVERSIDADE DE SÃO PAULO }
$$

FFCLRP - DEPARTAMENTO DE PSICOLOGIA E EDUCAÇÃO PROGRAMA DE PÓS-GRADUAÇÃO EM PSICOLOGIA

\title{
Consumo problemático de bebidas alcoólicas por mulheres: discursos e histórias
}

Clarissa Mendonça Corradi-Webster

Tese apresentada à Faculdade de Filosofia, Ciências e Letras de Ribeirão Preto da USP, como parte das exigências para a obtenção do título de Doutor em Ciências, Área: Psicologia 



\section{Consumo problemático de}

\section{bebidas alcoólicas por mulheres: discursos e histórias}

Orientadora: Profa. Dra. Regina Helena Lima Caldana

Tese apresentada à Faculdade de Filosofia, Ciências e Letras de Ribeirão Preto da USP, como parte das exigências para a obtenção do título de Doutor em Ciências, Área: Psicologia 
Autorizo a reprodução e divulgação total ou parcial deste trabalho, por qualquer meio convencional ou eletrônico, para fins de estudo e pesquisa, desde que citada a fonte.

FICHA CATALOGRÁFICA

Corradi-Webster, Clarissa Mendonça

Consumo problemático de bebidas alcoólicas por mulheres: discursos e histórias. Ribeirão Preto, 2009.

185 p.; $30 \mathrm{~cm}$

Tese de Doutorado, apresentada à Faculdade de Filosofia, Ciências e Letras de Ribeirão Preto/USP. Área de concentração:

Psicologia.

Orientador: Caldana, Regina Helena Lima

1. Bebidas alcoólicas. 2. Mulheres. 3. Construcionismo social. 4. Análise do discurso. 
Nome: CORRADI-WEBSTER, Clarissa Mendonça

Título: Consumo problemático de bebidas alcoólicas por mulheres: discursos e histórias

Tese apresentada à Faculdade de Filosofia, Ciências e Letras de Ribeirão Preto da USP, como parte das exigências para a obtenção do título de Doutor em Ciências, Área: Psicologia

Aprovado em:

Banca Examinadora

Prof. Dr.

Instituição: Assinatura:

Prof. Dr.

Instituição: Assinatura:

Prof. Dr.

Instituição: Assinatura:

Prof. Dr. Instituição: Assinatura:

Prof. Dr. Instituição: Assinatura: 

A todas as Mirians e Anas 



\section{AGRADECIMENTOS}

"Generosidade não é uma coisa, é uma forma de se relacionar que demanda ao menos duas pessoas - uma que oferece e outra que acolhe a oferta e a embeleza. O poder generativo desta forma de relacionamento permite que ambos sejam mais do que foram antes."

Murilo Moscheta (2009)

Em meu percurso tive inúmeros encontros, inúmeros momentos e relações generosas. $\mathrm{Na}$ impossibilidade de relatar todos os encontros que proporcionaram a história aqui narrada, nomeio e agradeço alguns deles.

A Deus, pela possibilidade da diversidade de histórias... sobre Deus, sobre mim, sobre a vida.

Às colaboradoras deste estudo, em especial à Miriam e Ana, por compartilharem suas histórias e possibilitarem este trabalho.

Aos meus pais, José Pompeo e Cleide, e a minha irmã Júlia, pelos momentos de descontração compartilhados, pelas palavras de encorajamento e confiança e por estarem sempre presentes. Obrigada por tudo.

Ao meu sempre companheiro Martin, por cuidar tão bem de mim enquanto eu tinha os olhos só voltados para a tese. E também por compartilhar de outras tantas diferentes vozes e discursos que os meus e com isto me possibilitar o aprendizado pela diversidade. Obrigada por tudo.

À Profa. Dra. Ana Maria Pimenta Carvalho, por compartilhar comigo reflexões, por confiar em meu trabalho, por me dar liberdade para fazer escolhas, por incentivar e legitimar minhas escolhas profissionais, por possibilitar um relacionamento que prima pela igualdade. Neste trabalho conjunto venho desconstruindo e reconstruindo posicionamentos enquanto psicóloga, professora e pesquisadora.

À Profa. Dra. Regina Helena Lima Caldana, por sua generosidade em me acolher como orientanda, por sua confiança em meu trabalho e por me lembrar da importância de manter o diálogo aberto com os diferentes interlocutores. 
À Profa. Dra. Sheila McNamee, por ter possibilitado tantos diálogos interessantes durante o meu trabalho e por ter meu incentivado ao uso do modo subjuntivo (E se...) em meu texto, em meus relacionamentos e em minha vida.

À Profa. Dra. Carla Guanaes, que vem gentilmente me acompanhando desde o início deste estudo, legitimando meu trabalho, fazendo sugestões, orientações, leituras e proporcionando espaço para o aprendizado.

Ao Prof. Dr. Emerson F. Rasera, por me lembrar que a ciência também é uma construção narrativa. Agradeço pelos importantes comentários e sugestões feitos em diferentes momentos de meu trabalho.

À Profa. Dra. Margarita Antonia Villar Luis, por legitimar e incentivar minha escolha por uma pesquisa qualitativa, pelas sugestões dadas sobre meu projeto e por me proporcionar inúmeras experiências de aprendizado no campo.

Ao Prof. Dr. Erikson F. Furtado, que muito vem contribuindo para minha construção como pesquisadora e terapeuta da área de álcool e outras drogas. Em minha formação enquanto terapeuta destacou a importância do relacionamento e da criatividade ao invés dos protocolos, técnicas e diagnósticos. Em minha formação enquanto pesquisadora chamou a atenção para a importância do aprofundamento no estudo dos temas trabalhados e para o compromisso da ciência com a transformação social.

À Profa. Dra. Marisa Japur, que me auxiliou em momentos de tomada de decisões importantes neste estudo e me possibilitou espaço de interlocução para refletir sobre as diversas questões abordadas aqui. E também por ter me chamado a atenção para os efeitos das histórias contadas e para a possibilidade de contar outras histórias.

À Profa. Dra. Ana Cristina Nassif Soares, pela gentileza de aceitar o convite para participar como membro de minha banca de defesa.

À Profa. Dra. Toyoko Saeki e Profa. Dra. Eucia Beatriz Lopes Petean, coordenadoras dos programas de Pós Graduação em Enfermagem Psiquiátrica e em Psicologia (respectivamente), pela compreensão quanto a mudanças ocorridas no decorrer de minha pós-graduação.

À Profa Dra. Edilaine Cristina da Silva e ao Prof. Dr. Rodrigo O. Moretti-Pires, pelos importantes convites de parceria, com os quais venho aprendendo muito. 
Ao Prof. Dr. Manoel Antônio dos Santos, pelos diálogos e oportunidades abertas.

À Profa. Dra. Rosalina Aparecida Partezani Rodrigues, pela oportunidade de crescimento na interdisciplinaridade e por me incentivar e apoiar em momento de decisão importante durante o processo de meu doutorado.

Ao Murilo Moscheta, pela generosidade com que vem me proporcionando sentidos sobre a teoria, sobre a arte, sobre a terapia, sobre a vida.

À Adriana C. F. Caldana, Alexandre Favero Bulgarelli, Claúdia Mara Pedrosa e Laura Vilela e Souza pelo gostoso diálogo e constantes trocas em nossos grupos de estudo. No nome deles agradeço também a todos os outros colegas com quem venho compartilhando grupos de estudo.

À Celiane Camargo-Borges, pelas leituras e diálogos sobre meu trabalho.

À Cristiane Reis e Paula Fabiana, queridas amigas, militantes feministas, com alma de artista e artista, que sempre me convidam ao olhar respeitoso para questões relacionadas à mulher.

À Flavia Abade, amiga que vive torcendo por mim e apostando em meu trabalho.

À Larissa Horta Esper, por dividir comigo histórias e conversas sobre estas e outras colaboradoras.

Aos amigos Maria Rosa, Rapeti, Fabio, Érika, Roberto, Karen, Marcos, Jane, Francesca, Luis, Mariana, Ricardo, Theresa, Paul, pela amizade em minhas constantes ausências.

Aos colegas da Escola de Enfermagem de Ribeirão Preto - USP, com quem, por meio de uma bela relação de interdisciplinaridade, venho me construindo como pesquisadora e psicóloga. Como tenho pouco espaço para agradecer a todos, nomeio aqui alguns: Ana Carolina, Andreia, Cheila, Fernanda Titareli, Juliana, Karina, Lívia, Miyeko e Paulo.

À Adriana (DEPCH-EERP), Kethleen (EERP) e Isilda (FFCLRP), queridas secretarias de programas de pós-graduação que pacientemente me ajudaram em diversos momentos importantes. 

Não sei... Se a vida é curta Ou longa demais pra nós, Mas sei que nada do que vivemos Tem sentido, se não tocamos o coração das pessoas.

Muitas vezes basta ser: Colo que acolhe, Braço que envolve, Palavra que conforta, Silêncio que respeita, Alegria que contagia, Lágrima que corre, Olhar que acaricia, Desejo que sacia, Amor que promove.

E isso não é coisa de outro mundo, É o que dá sentido à vida. É o que faz com que ela Não seja nem curta, Nem longa demais, Mas que seja intensa,

Verdadeira, pura... Enquanto durar 



\section{RESUMO}

CORRADI-WEBSTER, C. M. Consumo problemático de bebidas alcoólicas por mulheres: discursos e histórias. 2009. 185 f. Tese (Doutorado) - Faculdade de Filosofia, Ciências e Letras de Ribeirão Preto, Universidade de São Paulo, Ribeirão Preto, 2009.

Este estudo foi realizado com o uso do discurso construcionista social. De acordo com este discurso, a construção de sentidos sobre o mundo e sobre o homem se dá através da linguagem, nos relacionamentos. As construções são também circunscritas ao contexto histórico e cultural. A linguagem está institucionalizada através de discursos que produzem determinados efeitos, construindo modos de ser e de agir no mundo. No campo de estudos de álcool e outras drogas temos diversos discursos que regulamentam - consumo destas substâncias. O discurso construcionista social nos convida a problematizar estes discursos, assumindo postura crítica frente a eles. A literatura científica apresenta diversos discursos que auxiliam a construir sentido sobre o consumo de bebidas alcoólicas por mulheres. São destacados aqui os discursos epidemiológicos, biomédico, sociológico e psicológico, refletindo sobre efeitos destes discursos. Deste modo, o objetivo deste estudo foi fazer uma aproximação do discurso construcionista social para o campo de estudos do consumo de bebidas alcoólicas por mulheres, mais especificadamente, problematizar o vocabulário disponível na área para a significação das situações referentes ao uso de álcool; analisar as implicações identitárias dos discursos tradicionais da área; produzir interpretações alternativas relativas às questões de uso do álcool (individual e social). O estudo foi realizado em um serviço ambulatorial para tratamento de farmacodependências. Participaram do estudo duas mulheres que fizeram tratamento neste serviço, recebendo diagnóstico de síndrome de dependência de álcool (Miriam e Ana). Os instrumentos utilizados foram caderno de campo e entrevista de história de vida. A análise foi realizada em dois momentos: 1. Imersão no caderno de campo, onde foram identificados discursos, vozes e posicionamentos; 2. Imersão nas entrevistas, onde foi utilizada a ferramenta da análise do discurso, identificando discursos e efeitos destes para construção de versões identitárias e de práticas sociais. $\mathrm{Na}$ conversa com Miriam, construímos uma narrativa saturada pelo problema. Com o uso de alguns discursos (ex. papéis sociais de gênero, psiquiátrico, motivação interna) a versão construída da história de Miriam é a de alguém que está impotente frente ao consumo. Na conversa com Ana, construímos uma narrativa de sucesso. Com o uso de alguns discursos (ex. papéis sociais de gênero, autonomia) a versão construída da história de Ana é de alguém que não tem problema com o consumo de bebidas. Entretanto, este posicionamento é colocado em questão pelas vozes dos filhos. A partir de relatos de exceção, são oferecidas histórias alternativas às histórias dominantes. Os discursos produzem diferentes efeitos que só podem ser conhecidos com seu uso. É no relacionamento que os sentidos são construídos e que se abrem as possibilidades de mudança. A postura flexível, responsiva e de co-responsabilidade é sugerida para a abordagem da questão do consumo de bebidas alcoólicas por mulheres, considerando, nos relacionamentos, quais discursos possibilitam a construção de uma relação de ajuda.

Palavras-chave: Bebidas alcoólicas. Mulheres. Construcionismo social. Análise do discurso 



\begin{abstract}
CORRADI-WEBSTER, C. M. The problematic consumption of alcoholic beverages by women: discourses and stories. 2009. 185 p. Thesis (Doctorate) - Faculty of Philosophy, Sciences and Letters of Ribeirão Preto, University de São Paulo, Ribeirão Preto, 2009.
\end{abstract}

This study was carried out with the use of the social constructionist discourse. According to this discourse, the construction of meaning about the world and the being is through language in relationships. Constructions are also constrained by the historical and cultural context. Language is institutionalized through discourses that produce certain effects, constructing ways of being and acting in the world. In the field of study of alcohol and other drugs there are several discourses that regulate the use of these substances. The social constructionist discourse invites us to question these discourses, taking a critical stance towards them. The scientific literature presents several discourses that help to construct meaning about the consumption of alcohol by women. The epidemiological, biomedical, sociological and psychological discourses are highlighted here, reflecting on the effects of these discourses. Thus, the objective of this study was to bring the social constructionist discourse to the field of study of alcohol consumption by women, more specifically, to question the available vocabulary in the area used to make meanings of the situations regarding alcohol use; to analyze the identity implications of the traditional discourses in the area; to produce alternative interpretations concerning the issues of alcohol use (individual and social). The study was conducted in an outpatient clinic for substance abuse treatment and included two women who were treated in this service and had received diagnoses of alcohol dependence syndrome (Miriam and Ana). The instruments used were a field notebook and life story interview. The analysis was conducted in two parts: 1 . Immersion in the field notebook, which identified discourses, voices and positioning; 2 . Immersion in interviews, where discourse analysis was used, identifying discourses and the effects of these to construct versions of identity and social practices. In conversation with Miriam, we constructed a problem saturated narrative. With the use of some discourses (e.g. social roles of gender, psychiatric, internal motivation) a version of the story of Miriam as someone who is powerless against alcohol consumption was constructed. In conversation with Ana, we constructed a narrative of success. With the use of certain discourses (e.g. gender roles, autonomy) the version constructed of Ana's story is of someone who has no problem with drinking. However, this position is questioned by the voices of her children. From the reports of exception, alternative stories to the dominant stories are offered. Discourses produce different effects that can only be known through their use. It is in the relationship that the meanings are constructed and possibilities for change open up. A flexible, responsive and co-responsible approach is suggested to address the issue of alcohol consumption by women, considering, within the relationship, which discourses enable the construction of a therapeutic relationship.

Keywords: Alcoholic beverage. Women. Social Constructionism. Discourse Analysis 



\section{LISTA DE ANEXO E APÊNDICE}

APÊNDICE 1 - Termo de Consentimento Livre e Esclarecido ANEXO 1 - Autorização do Comitê de Ética 



\section{SUMÁRIO}

APRESENTAÇÃO.

01

CAPÍTULO 1. CONVITES CONSTRUCIONISTAS SOCIAIS PARA O CAMPO DE

ESTUDO DE ÁLCOOL E OUTRAS DROGAS.

CAPÍTULO 2. DISCURSOS DA LITERATURA CIENTÍFICA A RESPEITO DO

CONSUMO DE ÁLCOOL POR MULHERES

OBJETIVOS

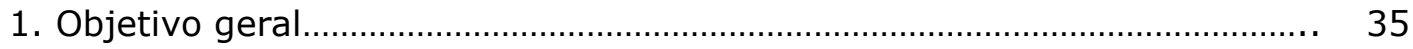

2. Objetivos específicos.................................................................................... $\quad 35$

CAPÍTULO 3. PERCURSO METODOLÓGICO

1. Delineamento teórico-metodológico da pesquisa........................................... 39

2. Local do estudo........................................................................................ 41

3. Colaboradoras do estudo................................................................................. 42

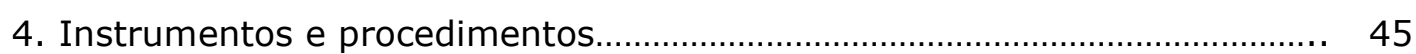

5. Considerações éticas...................................................................................... $\quad 50$

6. Análise do corpus..................................................................................... $\quad 50$

CAPÍTULO 4. HISTÓRIAS SOBRE O FAZER PESQUISA NESTA ÁREA.................. 57

CAPÍTULO 5. HISTÓRIAS DE MIRIAM

1. Diferentes formas de narrar a historia de Miriam........................................ 73

2. Convites feitos a partir da conversa com Miriam......................................... 99

3. Convite para construir outra versão para a história de Miriam................... 111

CAPÍTULO 6. HISTÓRIAS DE ANA

1. Diferentes formas de narrar a história de Ana............................................... 119

2. Convites feitos a partir da conversa com Ana............................................. 145

3. Convite para construir outra versão para a história de Ana........................ 153

CAPÍTULO 7. DISCURSOS E HISTÓRIAS............................................................... 155

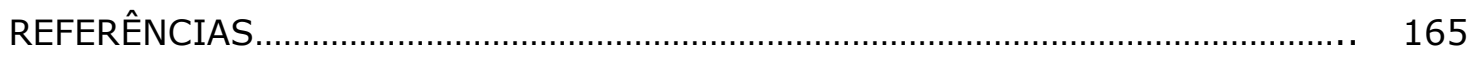

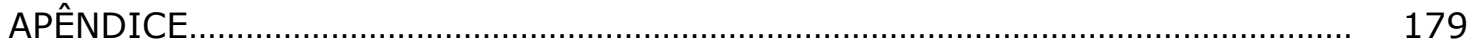

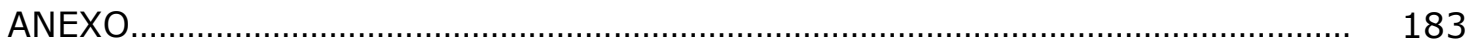



Apresentação 

Para Lieblich, Tuval-Mashiach e Zilber (1998) os seres humanos são contadores de histórias. Epston, White e Murray (1998) nos dizem que contando histórias as pessoas organizam suas experiências e dão sentido a elas e com isto podem ampliar ou restringir as possibilidades existenciais. Deste modo, inicio este trabalho contando um pouco de minha história e, com isto, busco organizar minhas experiências dentro do campo de estudo em que esta pesquisa se insere, contextualizando-a e, junto ao leitor, construindo um sentido a ela.

O campo de estudos de álcool e outras drogas vem ganhando muito atenção nos últimos anos. É crescente a preocupação com o manejo de questões relacionadas a este tema, tanto na pesquisa quanto na assistência. Na graduação já havia realizado alguns trabalhos preventivos com adolescentes que abordavam a questão das drogas, sob a supervisão da Profa. Rosalina Carvalho da Silva. Interessada pelo trabalho com adolescentes, depois de formada fiz estágio de aprimoramento profissional em psiquiatria e psicoterapia da adolescência no HCFMRP - USP (1998-2000), sob supervisão do Prof. Erikson F. Furtado. Neste período, seu grupo de pesquisa vinha realizando um estudo com líderes comunitários investigando as principais preocupações destes em relação aos adolescentes do bairro. O consumo de drogas apareceu em primeiro lugar (FURTADO, 1997). Comecei então a trabalhar como colaboradora de pesquisa em projetos, coordenados pelo Prof. Erikson, que tratavam sobre a identificação de fatores de risco para o consumo de substâncias entre adolescentes e modos de preveni-los (CORRADI; FURTADO, 1999; CORRADI; FIGUEROA; FURTADO, 2000). Em 1999, organizamos nossa primeira capacitação voltada para profissionais de saúde de um centro de puericultura com o objetivo de disseminar conhecimentos sobre drogas e fatores de risco, visando prevenir estes eventos. Foi um período de muita leitura, planejamento e trabalho, que resultou na proposta do PAI-PAD - Programa de Ações Integradas para Prevenção e Atenção ao Uso de Álcool e Drogas na Comunidade (FURTADO, CORRADI, FIGUEROA, 1999). Meu interesse na época era compreender porque algumas pessoas usavam drogas, porque algumas pessoas tinham problemas devido a este uso e como fazer para preveni-los. Curiosa pelo tema, em 2001, realizei um estágio em pesquisa na Universidade de Pittsburgh - PA, junto a Profa. Ada Mezzich, do CEDAR (Center for Education and Drug Abuse Research). Acompanhei estudos longitudinais, que buscavam, durante o desenvolvimento, fatores de risco para o uso de substâncias. Nesta ocasião fui apresentada ao tema "comorbidade". De volta ao Brasil, continuei meu trabalho de colaboradora de pesquisa, investigando entre adultos, a ocorrência de doenças psiquiátricas e uso de drogas (MACEDO; CORRADI; FURTADO, 2002). No ano de 2002, tive a oportunidade de participar, como consultora, de uma reunião de trabalho promovida pela Organização Mundial de Saúde na Espanha para discutir a implementação de estratégias de identificação precoce e intervenções breves para 
problemas relacionados ao álcool no Brasil (WORLD HEALTH ORGANIZATION, 2002). Com esta oportunidade, minhas leituras, pesquisas e trabalhos foram se focando no uso de drogas legais, mais especificadamente, no consumo de bebidas alcoólicas. Envolvida com as atividades de pesquisa e extensão relacionadas a este projeto, saí a campo conversando com profissionais da atenção primária sobre a temática, conhecendo como esta se apresentava e como era manejada nestes serviços. Junto a outros colegas do PAI-PAD, planejamos cursos de educação continuada, voltados para profissionais de saúde não especializados nesta área, dando início ao trabalho de implementação de estratégias de prevenção de problemas relacionados ao consumo de bebidas alcoólicas. Este trabalho me ajudou a compreender o conceito de droga de modo mais amplo, para além das drogas ilegais, algo que até então não era muito abordado. Ajudou-me também a refletir sobre o papel de profissionais não especializados na abordagem da questão e, com isto, a compreender o tema "drogas" para além do mundo "psi". Paralelamente, nos anos de 2003 e 2004, realizei, no Departamento de Medicina Social - FMRP - USP, meu mestrado que abordava o consumo de bebidas alcoólicas por pessoas em tratamento para transtornos psiquiátricos, sob orientação dos Profs. Erikson F. Furtado e Milton R. Laprega (CORRADI-WEBSTER; LAPREGA; FURTADO， 2009; CORRADI-WEBSTER; LAPREGRA; FURTADO, 2005). Este foi um período de muito aprendizado, pois além de meu envolvimento com o projeto de mestrado, trabalhava também no projeto PAIPAD/OMS e supervisionava psicólogos e psiquiatras em dois estágios de aprimoramento profissional (psiquiatria e psicoterapia da adolescência; atendimento em farmacodependências- HCFMRP-USP) (BATISTA et al., 2006). Pude aprender muito sobre epidemiologia, políticas de saúde e saúde pública, e aplicar o conhecimento das disciplinas nos projetos de pesquisa e extensão em que estava envolvida (FURTADO; CORRADI-WEBSTER; LAPREGA, 2008; MINTO et.al, 2005; CORRADI-WEBSTER et al, 2005). Entretanto, algo me incomodava. Na coleta de informações de meu mestrado, utilizei um questionário. Na análise dos resultados, tive muita vontade de poder ouvir aquelas pessoas um pouco mais e, mesmo fazendo uso dos critérios sugeridos para garantir a validade e confiabilidade das pesquisas quantitativas, tive dificuldades de considerar aquelas informações como "dados reais e objetivos". Com a experiência de ensino de profissionais de saúde, também fui percebendo que o tema álcool era construído de diversas maneiras, havendo, entretanto, certo discurso hegemônico e dicotômico, onde o consumo de bebidas alcoólicas era considerado como muito mais seguro do que qualquer droga ilegal (convidando à tolerância) e, ao mesmo tempo, como substância que destruía indivíduos e famílias (convidando à intolerância). Com a experiência de supervisão clínica, fui me abrindo para a riqueza do contar e construir histórias sobre/com outras pessoas. 
Neste mesmo período (2004), participei de uma disciplina de pós-graduação oferecida na FFCLRP-USP pelas Profas. Marisa Japur e Sheila McNamee (Universidade de New Hampshire) sobre práticas psicológicas e construcionismo social. Este novo discurso que se apresentava vinha legitimar o desconforto frente a meus dados do mestrado e oferecia-me ferramentas para refletir sobre o fazer pesquisa e sobre meu campo de estudos.

Em 2005, fui trabalhar na Escola de Enfermagem de Ribeirão Preto - USP (EERP), onde pude dar continuidade ao trabalho no campo de álcool e outras drogas, e aprofundar minha interlocução com profissionais de outras áreas. Envolvi-me com atividades de pesquisa e extensão do PROCURA - Programa de Reabilitação e Cuidados aos Usuários de Substâncias Psicoativas, coordenado pela Profa. Margarita A. Villar Luis, e com o curso de especialização "Formação de Pesquisadores para Álcool e outras Drogas", atualmente uma parceria da EERP com a SENAD (Secretaria Nacional de Políticas sobre Drogas). Estas foram oportunidades de novamente ampliar o olhar para todas as drogas (lícitas e ilícitas), para a assistência, e para questões relacionadas ao contexto macrossocial (políticas internacionais, contexto social e econômico). No PROCURA me envolvi com o atendimento de familiares e usuários de substâncias, sendo sensibilizada para a questão do sofrimento relacionado a esta temática. Esta sensibilização também ocorreu devido a minha inserção como supervisora de estágio de alunos de Enfermagem Psiquiátrica junto ao Caps-ad (Centro de Atenção Psicossocial Álcool e Drogas). No curso de especialização, como professora e orientadora, tive a oportunidade de expandir a troca com outros profissionais. Este curso recebe alunos do Brasil, da América Latina e de países africanos de língua portuguesa. São profissionais com formações diversas (advogados, enfermeiros, assistentes sociais, médicos, psicólogos, pedagogos, sociólogos, filósofos,...), vindos de diferentes contextos, possibilitando a expansão do aprendizado e de reflexões dentro deste campo de estudo. Ainda dentro do campo de álcool e outras drogas, junto a Profa. Sandra Cristina Pillon, envolvi-me com projetos de extensão junto a Secretaria de Assistência Social do município de Ribeirão Preto, ministrando workshops e supervisionando atividades de prevenção realizadas por acadêmicos de enfermagem junto a grupos de adolescentes (CORRADI-WEBSTER; ESPER; PILLON, 2009)

Em 2006, fui convidada pelo Prof. Rodrigo O. Moretti-Pires (na época docente da UFAM), para participar da implementação de estratégias de prevenção de problemas relacionados ao álcool no interior do Amazonas, o que me proporcionou a possibilidade de conhecer como este tema é abordado em um contexto diferente do interior de São Paulo e trocar experiências com profissionais que atuam neste contexto e com moradores 
locais (MORETTI-PIRES; CORRADI-WEBSTER; FURTADO， 2009 ${ }^{1}$; MORETTI-PIRES; CORRADI-WEBSTER, 2009²). Em 2007, supervisionei um grupo de alunos da EERP em atividades de extensão junto ao Projeto Rondon. Ficamos por 15 dias em Ribamar Fiquene, município do interior do Maranhão. Naquela oportunidade, trabalhamos, junto aos profissionais de saúde e educadores, o tema "consumo de bebidas alcoólicas". Foram conversas importantes, onde o consumo misturava-se a prazeres, rotina, vulnerabilidades e necessidades.

Como servidora da EERP também tive a oportunidade de participar do momento de construção de uma nova proposta político-pedagógica, que convida ao diálogo as diferentes disciplinas, visando abordar a questão do cuidado dentro de princípios do Sistema Único de Saúde, com grande foco na integralidade. Com isto, pude rever e reconstruir o que havia aprendido durante meu mestrado em saúde pública e, no trabalho com profissionais de outras áreas, rever-me e reconstruir-me enquanto psicóloga.

Também na EERP, comecei a trabalhar junto à Profa. Ana Maria Pimenta Carvalho, docente de disciplinas da área de psicologia. Acompanhando seu trabalho fui sendo convidada a me envolver em um movimento crítico-reflexivo e senti-me legitimada para rever conceitos, teorias e práticas (CORRADI-WEBSTER, CARVALHO; 2009³). Tive também a oportunidade de dividir com ela uma disciplina no curso de Especialização em Saúde Mental, onde junto aos alunos (enfermeiros psiquiátricos e psicólogos), refletimos sobre construções realizadas na área de psiquiatria e psicopatologia. Nesta parceria fui também apresentada para a linha de pesquisa que trata sobre saúde mental da mulher, onde este projeto de pesquisa se insere. Um dos estudos coordenados pela Profa. Ana Maria trata-se de levantamento de mulheres que passaram por tratamento psiquiátrico em serviço ambulatorial e seleção de algumas destas mulheres para entrevista, a fim de compreender as construções feitas por elas sobre a doença e o tratamento. Dentro deste contexto, decidimos pelo aprofundamento neste trabalho, do estudo sobre mulheres que passaram por tratamento devido ao consumo de bebidas alcoólicas. Fui incentivada a adotar o referencial teórico no qual já vinha fazendo aproximações e a construir este estudo/história de modo que refletisse parte de nossas inquietações junto a alguns discursos da saúde.

\footnotetext{
${ }^{1}$ MORETTI-PIRES, R.O.; CORRADI-WEBSTER, C.M.; FURTADO, E.F. Consumo de álcool e atenção primária no interior da Amazônia: sobre a formação de médicos e enfermeiros para assistência integral. Revista Brasileira de Educação Médica, 2009. (artigo encaminhado para apreciação)

${ }^{2}$ MORETTI-PIRES, R.O.; CORRADI-WEBSTER, C.M.; Validação do Alcohol Use Disorder Identification Test (AUDIT) para população ribeirinha do interior da Amazônia. Revista Latino-Americana de Enfermagem, 2009. (artigo encaminhado para apreciação)

${ }^{3}$ CORRADI-WEBSTER, C.M.; CARVALHO, A.M.P. Diálogos da Psicologia com a Enfermagem em tempos de transição paradigmática. Revista da Escola de Enfermagem da USP, 2009. (artigo encaminhado para apreciação)
} 
Com isto, apesar de já ter participado de leituras e disciplinas que tratavam sobre o discurso construcionista social, ao começar o doutorado, resolvi buscar outros interlocutores que poderiam me ajudar a refletir sobre a pesquisa e sobre a prática. Em 2007, comecei a participar de grupos de estudo coordenados pela Profa. Marisa Japur (FFCLRP), realizando posteriormente (2008), estágio de pesquisa na Universidade de New Hampshire, junto a Profa. Sheila McNamee. Dando continuidade a estes estudos, em 2009, comecei a participar de grupo de estudo coordenado pela Profa. Carla Guanaes, da FFCLRP. Junto a estes interlocutores (e a todos os outros colegas participantes dos grupos de estudo) pude desconstruir e reconstruir significados para os conceitos utilizados no campo, para minhas experiências na formação de profissionais e para minha atuação clínica. Foram novas e importantes vozes inseridas ao conjunto de outras tantas importantes vozes que me ajudam a construir significados sobre este temática.

Os leitores perceberão que este estudo constrói o objeto "consumo problemático de bebidas alcoólicas por mulheres" dentro de um campo maior, que é o de "álcool e outras drogas". Isto se deu por entender não ser possível construir sentidos sobre o consumo feito por mulheres, desconsiderando construções feitas no campo de álcool e outras drogas. Portanto, buscou-se problematizar e refletir sobre o vocabulário utilizado neste campo de estudos.

Trabalhando com um tema que vem causando tanta preocupação atualmente, sou solicitada para o diálogo constante com os diversos atores sociais (mídia, equipes de saúde, segurança, educação, serviço social, conselhos de representação profissional e população geral). Nestes encontros, sou geralmente convidada a me posicionar como 'representante da batalha contra as drogas', posicionamento este que venho tentando recusar e, ao invés disto, convidar meus interlocutores para a reflexão. Apesar de aceitar o posicionamento de 'profissional do campo de álcool e outras drogas', não aceito o posicionamento (talvez o mais conhecido pelo público em geral para os atores sociais que trabalham neste campo) de 'alguém que batalha contra as drogas'. Em minhas diversas imersões (em serviços de saúde, equipamentos sociais, visitas domiciliárias, congressos nacionais e internacionais da área, leituras, conversas e pesquisas) me agrada o convite para a reflexão sobre como este tema vem sendo construído e sobre quais outros discursos poderiam ser utilizados para esta construção. Com isto, parece-me que ficamos mais instrumentalizados e sensibilizados para ajudar pessoas que se sentem oprimidas frente às construções organizadas ao redor desta temática. Deste modo, gostaria de convidar os leitores a olharem para este tema de modo crítico, pensando-o para além do discurso alarmista da imprensa/literatura leiga (e muitas vezes também da científica).

Assim, este estudo é uma construção realizada no diálogo com diferentes vozes e discursos, de pesquisadores do campo de álcool e outras drogas, de pesquisadores construcionistas sociais, de profissionais especializados e não especializados, de pessoas 
que tiveram seu consumo construído como problemático e de outras que não tiveram. E é este o convite deste estudo. Trazer diferentes vozes e discursos para construir sentidos sobre este campo, entendendo que é pela flexibilidade no uso de discursos e vozes que podemos construir diferentes possibilidades de diálogo, e assim dar sustentação para políticas de saúde, para projetos de prevenção e tratamento.

Deste modo, no Capítulo 1, são apresentadas as premissas básicas do discurso construcionista social, utilizando-as para refletir sobre conceitos do campo de estudo de álcool e outras drogas. No Capítulo 2, são apresentados os discursos utilizados pela literatura científica na construção de sentidos sobre o consumo de bebidas alcoólicas por mulheres, sendo também discutidos alguns possíveis efeitos destes discursos. Este capítulo também traz os objetivos deste estudo.

O Capítulo 3 apresenta o percurso metodológico. No Capítulo 4, a partir de anotações de meu caderno de campo, trago reflexões sobre o fazer pesquisa na área de álcool e outras drogas. No Capitulo 5, apresento diferentes versões da história de Miriam, convidando o leitor a refletir sobre alguns temas que me pareceram pertinentes após o trabalho de análise da entrevista. No Capítulo 6, apresento versões da história de Ana, fazendo outros convites à reflexão. O Capítulo 7 tem como objetivo fazer colocações que possibilitem um movimento dialógico e reflexivo, com base nos discursos e histórias apresentados nos capítulos anteriores.

Convido o leitor a pensar nos discursos e histórias que constroem seu entendimento sobre a temática e a colocá-los em diálogo com os discursos e histórias apresentados. 
Capítulo 1

Convites construcionistas sociais para o campo de estudo de álcool e outras drogas 

Este primeiro capítulo tem como objetivo apresentar as premissas básicas do discurso construcionista social e utilizá-las para refletir sobre o campo de estudo de álcool e outras drogas.

O discurso construcionista social é compartilhado por vários autores, de diferentes disciplinas, com algumas posições diversas (GERGEN; GERGEN, 2003; BURR, 2003). Chamaremos aqui de discurso construcionista social e não de teoria construcionista social, seguindo a sugestão de Guanaes (2004) de que a palavra "teoria" traz a idéia de algo que representa a realidade e que explica de modo válido e fidedigno a natureza do mundo e das pessoas. Como veremos adiante, estas não são propostas construcionistas sociais, já que os autores entendem que as teorias são legitimadas apenas dentro de um contexto histórico e cultural definido. Ao chamarmos de discurso construcionista social, convidamos o leitor a não aceitá-lo como verdade, mas como uma forma de construir um entendimento sobre o mundo e sobre as pessoas. Hosking e McNamee (2009) sugerem que o discurso construcionista seja entendido como um discurso das ciências humanas que oferece uma orientação geral sobre processos relacionais, incluindo a pesquisa.

Os autores construcionistas estão sempre nos convidando a refletir sobre o mundo e sobre como entendemos este mundo. Diante da afirmativa: "a embriaguez causa prejuízos ao homem", o discurso construcionista nos convida a pensar sobre o contexto histórico e cultural em que esta afirmativa foi feita; 1 ) sobre a qual homem a afirmativa se refere - a todos? ao sexo feminino? ao sexo masculino? ao pobre? ao bem sucedido? ao que cumpre todos seus deveres? ao que não contribui para o sistema capitalista?; 2) sobre quais situações causam prejuízo - na festa de formatura? em um boteco qualquer em um dia qualquer? em uma cerimônia religiosa? no dia em que recebeu uma promoção no emprego? quando está em casa se sentindo só? quando perdeu um ente querido? na festa de casamento da filha?; 3) sobre as ações advindas desta descrição - prevenir a embriaguez? punir quem se embriaga? continuar se embriagando pois nunca teve prejuízos? esconder-se quando embriagado?; 4) e sobre formas de descrever a embriaguez - doença?; caráter?; linguagem?

O discurso construcionista social propõe que ao afirmarmos algo sobre o mundo, estamos construindo esta realidade no mundo e não a representando. Não há algo dado no mundo que passivamente relatamos ao fazermos uma descrição. Mesmo quando pensamos em nossas experiências pessoais, elas existem apenas dentro do discurso. Isto não significa que não houve um "algo que aconteceu". Mas ao falarmos sobre este "algo que aconteceu", ao descrevê-lo, já estamos entrando no campo da linguagem e do discurso. Desta forma, o discurso construcionista social é ontologicamente mudo, ou seja, não se preocupa em se aproximar do fenômeno e sim em conhecer como as pessoas constroem significado sobre este (GERGEN, 1999). 
Ao questionar a existência de uma verdade única e universal, ele nos convida a conhecer o que é tomado por verdade, a pesquisar como se deu esta construção e a pensar alternativas a ela. Um exemplo é o estudo Spink, Lisboa e Ribeiro (2009) que descreve como se deu a construção do tabagismo como problema de saúde pública. Os autores propõem que isto só aconteceu devido ao aumento de estudos científicos que buscavam comprovar os malefícios do cigarro, associado ao novo discurso da saúde pública de controle comportamental para prevenir fatores de risco e também ao cenário político transnacional advindo do pós-guerra, que resultou na criação de instituições com objetivos de organizar políticas mundiais, como a Organização das Nações Unidas e a Organização Mundial de Saúde. Desta forma, os autores não naturalizam o tabagismo como problema de saúde pública, mas analisam como esta construção ocorreu em um contexto histórico e cultural definido.

As pesquisas construcionistas terão como foco o estudo do processo de como as pessoas descrevem o mundo e a si mesmo (GERGEN; GERGEN, 2003), ou seja, como elas constroem significados, organizam suas ações e nomeiam suas experiências, suas emoções, sua identidade. Considera-se que há diferentes formas de descrever os eventos e que cada uma destas descrições construirá uma verdade. Entretanto, entende-se que algumas descrições serão mais legitimadas que outras pelos processos sociais, sendo estas então consideradas "a verdade".

Para estudar o processo de construção significados, é importante conhecer o contexto histórico e cultural no qual os sentidos são construídos. A forma como conhecemos o mundo e como damos significados às nossas experiências variam de acordo com este contexto, sendo dependente de arranjos econômicos e sociais prevalentes naquela cultura naquele período. Percebemos então, que os significados não são construídos individualmente. Os sentidos sobre o mundo são criados em nossas interações sociais, em nosso "compartilhar o mundo". Quanto a isto, Nutt (2009) chama a atenção para como a legislação e as políticas que regulam o consumo de drogas são feitas. Para o autor, as classificações utilizadas na área para, por exemplo, definir quais drogas são legais ou ilegais, ou definir a severidade da punição que o portador da substância será alvo, não estão relacionadas apenas com os danos que as drogas causam. Por trás de uma política, há pressões externas vindas do público, da mídia, de especialistas da área, de grupos organizados, de políticos e de parceiros internacionais. Desta forma, classificar ou não uma droga como ilegal não está diretamente relacionado com os danos que esta pode causar. Nutt também classificou 20 substâncias de acordo com a possibilidade de causarem danos físicos, sociais e dependência. Nesta classificação o álcool é colocado como a $5^{a}$ substância mais danosa, perdendo apenas para a heroína, cocaína/crack, barbitúricos e metadona. Outras drogas legais como os benzodiazepínicos são colocados em 70 lugar, o tabaco em 90 lugar e drogas ilegais como a maconha 
aparece em $11^{\circ}$ lugar, o LSD em $14^{\circ}$ lugar e o ecstasy em $18^{\circ}$ lugar. Entretanto, muitas vezes estas informações não são colocadas para o público em geral, que fica alarmado frente a qualquer consumo de droga ilegal e percebe as legais como drogas mais fracas. Ser ou não uma droga legal é uma construção social, com diversas variações na história e nos diferentes contextos.

As pessoas, ao negociarem certas formas de conhecer o mundo, negociam também formas de agir sobre ele. (BURR, 2003). No campo de estudo de álcool e outras drogas temos um interessante exemplo: estudos indicam que a metadona causa mais dependência e efeitos adversos do que a heroína, entretanto a primeira é tratada como eficiente medicamento para a dependência da segunda, uma droga ilegal. Tratar a heroína como droga ilegal faz com que esta seja distribuída por traficantes, enquanto tratar a metadona como medicamento leva à distribuição desta por serviços de saúde. Desta forma, o "drogado" torna-se "paciente" e a "dependência", torna-se "tratamento". Esta negociação de sentidos leva-nos a descrever o dependente de heroína como criminoso, anti-social e drogado, assim como o leva a agir como tal. Por outro lado, o dependente de metadona é descrito como paciente e cidadão disciplinado a caminho da recuperação, agindo também como tal (BOURGOIS, 2000).

Da mesma forma, compreendendo que os arranjos sociais não são apenas ditados por leis e políticas, mas também negociados em pequenos grupos (MACRAE, 2009), usuários de heroína consideram os usuários de metadona como 'pessoas no fim do trilho', que por estarem com a saúde frágil e/ou sem condições de ganharem o dinheiro necessário para comprar a heroína, recorrem à dependência de metadona (BOURGOIS, 2000).

Ampliando a questão para outras substâncias, uma pessoa que bebe e embriagase aos finais de semana, vivendo em uma família evangélica, poderá ser considerado pelos familiares como tendo problema com bebida, enquanto outra pessoa, que também bebe e embriaga-se aos finais de semana, mas que participa de um meio familiar onde todos se encontram aos finais de semana para fazerem churrasco, grandes almoços e beberem, sua embriaguez será considerada como algo normal.

Vemos então, que as descrições sobre o mundo são resultados de ações coordenadas entre os homens, sendo no contexto relacional que determinada palavra ou sentido ganhará inteligibilidade. Uma afirmação não traz um sentido em si, seu sentido só será revelado quando o outro responder a ela. O sentido então é construído na coordenação de um enunciado com a resposta a ele (GERGEN, 2007). Desta forma, quando falo sobre "uso problemático de álcool" com meus colegas pesquisadores da área, entendemos este uso como um consumo de bebidas alcoólicas que pode trazer conseqüências ao individuo (ex. acidente automobilístico, dependência). Ao falar sobre "uso problemático de álcool" para membros de uma religião onde o consumo de bebidas 
alcoólicas é proibido, este pode ser entendido como qualquer consumo de álcool. Para alguns usuários de bebidas alcoólicas, o "uso problemático de álcool" pode ser considerado o consumo de etanol puro ou o fato da pessoa ter que pedir dinheiro para comprar bebidas. Caso estes três grupos conversem sobre o consumo de bebidas de determinada pessoa, esta pessoa será classificada de modo diferente por cada um deles. O sentido de "uso problemático de álcool" será construído de modos diferentes dentro de comunidades discursivas diferentes. O significado das palavras variam de acordo com quem as usa, para quem estão direcionadas e em qual contexto (DE SHAZER, 1994).

Percebe-se então, que os relacionamentos humanos têm papel central na produção e na sustentação de determinado conhecimento, incluindo o científico. $O$ conhecimento não é dado pela natureza e também não é produto de uma mente individual, ele é construído dentro de uma comunidade que compartilha modos de compreender e dar sentindo ao mundo, sendo portanto, de natureza relacional. Falar do significado como algo relacional implica em tirar o foco do indivíduo, de suas motivações internas, de seus desejos inconscientes e de suas crenças pessoais para centralizar em como as pessoas coordenam suas ações. A construção de significados é assim entendida como resultado de uma ação conjunta (MCNAMEE, 2004). Ao fazer um enunciado, o indivíduo sempre estará em interação com outras pessoas, que podem estar presentes ou presentificadas como vozes internas (SPINK, 2004).

O conceito de vozes foi trabalhado pelo filósofo e crítico literário russo Mikhail Bakhtin. Para este autor, cada voz é formada em um processo contínuo de antecipação e resposta a outras vozes, sendo que cada voz contém vozes de outros. Para ele, as vozes das pessoas estão sempre permeadas por vozes de outros. Cada voz resiste e contesta outras vozes, assim como também acata outras. Para Bakhtin a vida requer o diálogo e estar fora do diálogo significa estar morto (FRANK, 2005). Sendo assim, conhecer com quais vozes o indivíduo dialoga ao construir determinado significado pode nos ajudar a conhecer como se deu este processo de construção. No trabalho clínico de um profissional da área de álcool e outras drogas, somos diversas vezes procurados por pessoas preocupadas com o consumo de substância de um familiar. Na conversa podemos identificar algumas vozes que são trazidas para construir este consumo como problema ou para construir o sentimento de ambivalência frente $a$ isto. $O$ familiar pode trazer a voz de um professor dizendo que o consumo é prejudicial, de um policial dizendo que esta substância pode ser a porta de entrada para outras, de um vizinho que dizia que o consumo de drogas é um caminho sem volta, de um colega da faculdade que diz que não há problema neste uso, de um cantor que defende sua legalização, dentre outras.

Nos relacionamentos, as palavras ganham significados através de "jogos de linguagem" (WITTGENSTEIN, 2003). Os jogos de linguagem dizem respeito ao modo 
como as palavras são utilizadas, de modo continuado e padronizado, tendo significado compartilhado pelo grupo. Desta forma, ao usarmos o termo "dependência de álcool", poderíamos pensar que este se refere ao um padrão de consumo que sempre existiu na história da humanidade, independente de ter sido descrito pela medicina. Entretanto, de acordo com o proposto por Wittgenstein, este termo não descreve certo padrão de consumo existente, mas constitui as características deste. Ao se descrever tal consumo como dependência de álcool, constrói-se a dependência, com todos significados que esta tem para o grupo em questão.

Desta forma, a linguagem em ação é também considerada uma prática discursiva, referindo-se à forma como a pessoa cria, transforma e ressignifica os fenômenos. A linguagem não só diz como é o mundo, como também o constitui (GRACIA, 2004). Alguns autores nomeiam esta característica da linguagem como "papel performático da linguagem" (GUANAES, 2006; SPINK, 20004; BURR, 2003; POTTER; WETHERELL, 1987). Cada descrição e explicação sustentam e suportam alguns padrões de exclusão e convidam a outros. Alterar descrições significa deixar de lado algumas ações e convidar outras. Sendo assim, as diferentes formas de descrever o mundo levam a diferentes formas de agir sobre o mundo (RASERA; JAPUR, 2005). Como profissionais da área de álcool e drogas, ao descrevermos tal comportamento como "dependência de álcool", convidamos a pensar sobre doença, prejuízos, sofrimento, mudança, tratamento e a não pensar sobre diversão, prazer, opção, benefícios.

Ao pensar a linguagem como prática social, somos convidados a pensar sobre a utilidade de nossas descrições. Diferentes construções do mundo sustentam diferentes tipos de ação social (BURR, 2003). Se ao usarmos a linguagem para descrevermos algo, construímos determinado fenômeno, abrimos e fechamos possibilidades de interação com este, nossas descrições estão sendo úteis ou não? Ao que elas vêm nos levando? Que possibilidades abrem? Que possibilidades fecham? Fazermos um diagnóstico de "dependência de álcool" abre a possibilidade para que a pessoa procure ajuda? Para que a família procure apoio? Ou desempodera a pessoa frente à dependência? Faz com que a família fique culpada e se esconda?

Entretanto, apesar da linguagem proporcionar mudanças, ela também está institucionalizada através dos discursos. Os discursos são um conjunto de significados, metáforas, representações, imagens, histórias e afirmações que produzem uma versão particular de um objeto (POTTER; WETHERELL, 1987). É a linguagem vista a partir das regularidades (SPINK, 2004). Sendo assim, ao redor de um objeto há uma variedade diferente de discursos e cada um nos conta uma história diferente do objeto em questão. Eles não estão disponíveis igualitariamente, havendo discursos mais hegemônicos ou unitários, que assumem o status de fato e são considerados verdade, ou seja, descrições acertadas sobre o objeto. Alguns autores defendem que atualmente, o discurso médico, 
mais especificamente o discurso do diagnóstico psiquiátrico, vem se mostrando como um poderoso discurso hegemônico que funciona de modo a determinar critérios de normalidade, definir posições de sujeito assimétricas para os que estão implicados no encontro clínico e para definir o que é um conhecimento válido, quem tem acesso a ele, como este conhecimento deve ser comunicado e mostrado (AVID, 2005). Compreendendo que os discursos são recursos culturais que podem abrir ou fechar possibilidades de ação (WALTON, 2007), o diagnóstico psiquiátrico é exemplo de um discurso poderoso, que de um lado pode limitar o espectro de possibilidades de entendimento de um problema e do outro lado pode colocar as dificuldades psicológicas como localizadas dentro do indivíduo, podendo ajudar a construir uma identidade patológica e tirar da pessoa seu agenciamento (AVID, 2005). O discurso da dependência enquanto doença está ancorado aos discursos médico e psiquiátrico. Alguns autores questionam os efeitos deste discurso, que pode desempoderar a pessoa que deseja parar de usar uma substância, mas se sente fraca frente a esta doença crônica (BURR, 2003).

Há uma tendência dos discursos permanecerem no tempo, apesar de existir a possibilidade de mudança (SPINK, 2004). Nos relatos, estes discursos estarão presentes, influenciando o modo como as pessoas constroem significados e constroem sua identidade (BURR, 2003). Entretanto, os discursos devem ser compreendidos em uso, já que o mesmo discurso pode levar ao empoderamento em uma situação e enfraquecer em outra. O discurso da dependência enquanto doença pode ser libertador, tirando o julgamento moral, e também pode aprisionar, vitimizando o dependente. Desta forma, os discursos devem ser entendidos dentro do processo conversacional e devem ser contextualizados a ele.

Para o discurso construcionista social, o papel da linguagem é tão central que alguns autores afirmam que a pessoa não pode pré-existir à linguagem, já que é na linguagem que a pessoa é construída (BURR, 2003). Com isto, querem dizer que a linguagem nos oferece uma forma de estruturar nossas experiências do mundo e de nós mesmos. Segundo Burr, isto nos leva a duas reflexões: 1) O que pensamos constituir o ser humano (personalidade, motivações, desejos, sentimentos) não é intrínseco a ele. São descrições que aparecem nos relacionamentos a partir da linguagem, a fim de nos auxiliar a organizar nossas experiências. 2) Como estas características não são intrínsecas ao homem, podem ser construídas de modo diferente, ou seja, há possibilidades alternativas de construção do self e dos eventos.

Entretanto, como já foi tratado anteriormente, as construções não são individuais e isto inclui as construções a respeito do self. O self é entendido como produto da linguagem e das interações humanas. Sendo assim, é visto como algo fluido, que passa por mudanças constantes dependendo de com quem a pessoa está, em quais circunstâncias, e fazendo o quê. A idéia do ser humano unificado, coerente e com uma 
personalidade é descartada. E se é na linguagem que os selves são criados e mantidos, é também pela linguagem que se podem promover mudanças. Para ilustrar, trago o relato de um programa produzido pela TV Record no ano de 2008 e reprisado em 2009. É um reality show chamado "Troca de Família". Neste programa, duas mulheres vindas de locais diferentes e que não se conhecem, passam uma semana na casa da outra, tendo que assumir algumas responsabilidades da dona da casa original. Em um dos episódios deste programa, uma das mulheres é descrita inicialmente como "de bem com a vida", muito sociável, alegre, extravagante, batalhadora, boa mãe, esposa companheira e responsável. Ela é o marido são jornalistas de um município no interior de Minas Gerais e são conhecidos pelos eventos que produzem, por serem boêmios e polêmicos. Esta mulher vai passar uma semana em um apartamento em São Paulo, em uma casa extremamente organizada, onde a mulher é uma dona de casa orgulhosa por sua dedicação exclusiva ao lar. Convive com seu marido e filhas, com uma rotina e com valores completamente diferentes dos seus. Começa a ser descrita por esta nova família como irresponsável, imatura, difícil de relacionar, descontrolada e alcoólatra. Com novas vozes, novas descrições de self foram apresentadas, que em conflito com as vozes e descrições que tinha, levaram-na ao que foi considerado como surto psicótico devido a uma situação de estresse e à internação psiquiátrica. Neste episódio percebe-se que uma vez que a pessoa é retirada de seus relacionamentos, as descrições sobre o self perdem o sentido. Desta forma, os autores construcionistas compreendem que traços de personalidade são descritos em função de circunstâncias culturais, históricas e relacionais (BURR, 2003).

Com isto, pensamos que as pessoas não possuem um self, mas múltiplos selves, ou seja, múltiplas formas de se descreverem e serem descritas, variando de acordo com suas relações. Entretanto, temos em nossa sociedade uma percepção de continuidade no espaço e no tempo, percepção esta que nos tranqüiliza. Situações em que esta percepção é rompida são identificadas por nós como problema e assim podem trazer sofrimento ao indivíduo (HARRÉ; LANGENHOVE, 1999). Cooperando com este senso de unidade, aparece o nome próprio. Para Bordieu (1986), as narrativas socialmente bem aceitas preservam a unificação do eu, institucionalizado em nossa sociedade através no nome próprio, que seria "um ponto fixo num mundo que se move", ajudando assim a construir a idéia de identidade. O nome próprio asseguraria a constância através do tempo e a unidade através dos espaços sociais nos quais o indivíduo se apresenta das mais diversas formas e assume os mais diferentes papéis, preservando, entretanto sua idéia de unicidade e individualidade.

O discurso construcionista social pode ser útil para refletirmos sobre o campo de estudo de álcool e outras drogas. Autores construcionistas apontam que uma das premissas deste discurso é assumir uma postura crítica diante das afirmativas científicas 
que são tomadas como certas, ou seja, como óbvias. Convidam-nos a problematizar o conhecimento que é tomado como objetivo e a refletir sobre o modo como entendemos o mundo e a nós mesmos. Entendendo que as construções ocorrem em um contexto histórico e cultural definido, este discurso nos convida a refletir sobre algumas construções feitas no campo de estudo de álcool e outras drogas. Classificações utilizadas no campo, como legais e ilegais, leves e pesadas, medicamentosas ou recreacionais são construções históricas, culturais e relacionais. Ao contrário do que muitas vezes entendido pelo público em geral, estas descrições constroem a realidade e não a descreve. São feitas através da linguagem e, a partir destas, realidades diferentes são construídas. Desta forma, diferentes construções podem levar a descrições de usuáriopaciente ou usuário-drogado ou usuário-bon vivant e assim, construir diferentes possibilidades de ser no mundo.

De acordo com este entendimento, as pesquisas científicas são também processos relacionais, inseridas em um contexto histórico e cultural. Também criam "verdades" e não representam "verdades". Para Foucault (2004), a ciência é atualmente uma das principais instituições de produção de "verdades". Deste modo, neste estudo, trataremos os resultados descritos na literatura científica como discursos da ciência, compreendendo que estes apresentam versões do mundo e que, as diferentes versões, terão diferentes efeitos na constituição dos mundos.

Como o foco deste estudo é o uso de álcool por mulheres, o capítulo seguinte dará continuidade a este diálogo reflexivo, apresentando discursos da literatura sobre este consumo e discutindo alguns possíveis efeitos produzidos por estes discursos. 
Capítulo 2

Discursos da literatura científica sobre o consumo de bebidas alcoólicas por mulheres 

Desde o Iluminismo, no século XVIII, a ciência vem sendo considerada importante instituição na produção da "verdade". Através do desenvolvimento de métodos, a ciência vem buscando garantir que esta "verdade" seja acessada com o máximo de objetividade e de neutralidade possíveis. Nesta busca pela verdade, muitas vezes rejeita formas de inteligibilidade que não as científicas e, assim como a religião, utiliza a retórica da exclusão, sendo a "verdade" usada como instrumento repressor. Desta forma, apesar de clamar pela liberdade de pensamento, suas instituições são muitas vezes tão dogmáticas como as instituições religiosas (GERGEN, 2007).

Utilizando esta reflexão como pano de fundo e o convite do discurso construcionista social de assumir uma postura crítica em relação ao conhecimento tomado como óbvio, este capítulo traz uma apresentação e reflexão sobre alguns discursos científicos a respeito do consumo de álcool por mulheres. De modo didático, serão nomeados aqui alguns discursos amplos (epidemiológico, biomédico, sociológico e psicológico). Entretanto, como nos lembra Iñiguez (2004), todo discurso é dependente de outros, ou seja, estão ancorados em outros discursos. Deste modo, veremos que a literatura apresentada também traz o discurso psiquiátrico, o discurso dos papéis sociais de gênero, o discurso psicanalítico, o discurso do feminismo, dentre outros.

O campo de estudo sobre o uso de álcool entre mulheres parece ser novo, apesar do consumo de bebidas alcoólicas fazer parte da vida social de homens e mulheres há muitos anos. Na década de 70 apareceram os primeiros estudos sobre o uso de álcool entre mulheres, onde o foco era o uso durante a gestação, entretanto, a preocupação destes estudos era o feto e não a mulher. Nos últimos anos o número de estudos vem aumentando, sendo este aumento apontado pela literatura como influenciado pelos seguintes fatores: papel da mulher como reprodutora e como agente de socialização, início das pesquisas feministas e aumento do consumo de álcool entre as mulheres ocidentais. O uso de álcool entre as mulheres parece também ter se tornado foco de atenção pública a partir do momento em que elas começaram a reivindicar aumento do status, do poder e de recursos financeiros (AHLSTRM, $1995^{4}$ apud ALLAMANI, 2008).

Iniciaremos a apresentação dos discursos da literatura pelo discurso epidemiológico. De acordo com este discurso, é preciso conhecer como determinado evento se apresenta na população a fim de planejar políticas de saúde. Em relação ao consumo de bebidas alcoólicas, a literatura epidemiológica vem mostrando que as mulheres consomem bebidas alcoólicas em menor quantidade que os homens, sendo estes números confirmados pelos diferentes estudos realizados na área. Um levantamento domiciliar sobre o uso de álcool e outras drogas realizado no Brasil em 2001, apresentou que a prevalência de dependência de álcool entre os homens foi de

\footnotetext{
${ }^{4}$ AHLSTRM, S. Cultural differences in women's drinking. Contemporary Drug Problems, v. 22 , p. 393-451, 1995.
} 
$17,1 \%$ e entre as mulheres foi de 5,7\%, em uma razão de 3:1 (CARLINI et al., 2002). Números apresentados pela Organização Mundial de Saúde (OMS) sobre países classificados como America B, onde o Brasil está incluído, apontaram que $75 \%$ dos homens eram consumidores regulares de bebidas alcoólicas enquanto esta porcentagem entre as mulheres era de 53\% (WILSNACK; WILSNACK; OBOT, 2005). Em 2007, foi realizado o mais recente levantamento sobre o uso de álcool no Brasil. Nas diversas questões feitas aos participantes, os homens afirmaram em maior freqüência que as mulheres fazer o consumo de álcool. Em relação à abstinência ou ao beber menos do que uma vez ao ano, o número entre as mulheres foi maior do que entre os homens ( $59 \%$ das mulheres e $35 \%$ dos homens). Neste mesmo estudo, $11 \%$ dos homens e $2 \%$ das mulheres afirmaram consumir bebidas alcoólicas diariamente. Em relação ao binge drinking (consumo de 05 ou mais doses de bebidas alcoólicas em uma ocasião), 38\% dos homens e $17 \%$ das mulheres disseram fazer este tipo de consumo. Em questões que investigavam a associação entre o consumo de álcool e problemas, esta associação foi encontrada em $37 \%$ dos homens e em $11 \%$ das mulheres. Na classificação utilizada para pontuar "uso nocivo", $5 \%$ dos homens e $1 \%$ das mulheres preencheram estes critérios e na classificação para "dependência", 14\% dos homens e $4 \%$ das mulheres foram considerados como dependentes (LARANJEIRA; PINSKY; ZALESKY, 2007)

Em países com a economia desenvolvida, como os Estados Unidos da América (EUA), a literatura também apresenta números que indicam que o consumo entre as mulheres é menor. De acordo com o "National Comorbidity Survey", 38,6\% dos homens e $19,7 \%$ das mulheres preencheram pelo menos um critério utilizado para classificar a dependência de álcool. Ainda, segundo este levantamento, foi estimado que em algum momento da vida, $12,5 \%$ dos homens e $6,4 \%$ das mulheres preencheriam os critérios necessários para classificar consumo abusivo de álcool e 20,1\% dos homens e $8,2 \%$ das mulheres preencheriam todos os critérios necessários para classificar como dependência de álcool (KESSLER et al., 1994). Apesar de tanto os números produzidos no Brasil (país em desenvolvimento econômico) como os produzidos nos EUA (país desenvolvido) indicarem que as mulheres consomem menos bebidas alcoólicas do que os homens, a literatura nos diz que quanto maior a equidade social em relação ao gênero no país, mais próximo será o modo como os homens e as mulheres consomem estas bebidas. Um estudo realizado na Europa concluiu que a menor diferença de consumo de álcool entre os gêneros foi nos Países Nórdicos, seguida pelos da Europa Ocidental e Central, sendo que as maiores diferenças foram encontradas nos países com economia em desenvolvimento (BLOOMFIELD; GMEL; WILSNACK, 2006). Fica uma pergunta: será que nestes países as mulheres bebem mais ou será que, devido a maior equidade de gênero, se sentem mais à vontade para responder afirmativamente às questões da pesquisa? 
Sendo assim, o discurso da literatura epidemiológica constrói o consumo de álcool como algo marcado pelas diferenças de sexo, em que pessoas do sexo feminino beberiam menos do que as do sexo masculino. Um dos possíveis efeitos deste discurso é a estigmatização das mulheres que bebem, principalmente em contextos onde as relações de gênero são menos igualitárias. Ao consumirem bebidas alcoólicas tornam-se diferentes da norma, do comportamento esperado de uma mulher. Se este consumo for diário, provavelmente será apontado pelas pessoas ao redor como uso problemático, já que há poucas mulheres com o mesmo hábito. Este discurso pode construir na mulher que bebe sentimentos de culpa e vergonha, levando-a a responder negativamente quando questionada sobre seu consumo (minimizando os dados epidemiológicos) e a escondê-lo de outras pessoas e de profissionais de saúde. Deste modo, o número de mulheres que consomem bebidas alcoólicas seria maior do que o preconizado pela literatura epidemiológica. Neste caso percebe-se que o discurso epidemiológico tem uma influencia grande do discurso dos papéis sociais de gênero, sendo que um auxilia na constituição do outro.

Outro discurso que vem sendo muito valorizado pela literatura no campo de estudo de álcool, é o discurso biomédico. O discurso biomédico ajuda a construir explicações biológicas para os eventos, sendo muito utilizado em questões que envolvem o sexo feminino (VIEIRA, 2002), e legitimar o discurso de dependência enquanto doença. No campo de estudos de álcool, Midanik e Room (2005) colocam que quanto mais o discurso biomédico ganha força, mais a questão do consumo é tratada de modo individualizante e menos se consideram os aspectos relacionados ao ambiente.

De acordo com este discurso, após consumir bebidas alcoólicas, as mulheres teriam níveis maiores de álcool no sangue do que os homens. A concentração de álcool no sangue estaria relacionada com o índice de massa corporal e com a quantidade de água no corpo, sendo ambas menores nas mulheres do que nos homens, causando uma difusão mais lenta e aumentando a concentração de álcool no sangue da mulher. A atividade da enzima álcool-desidrogenase também parece ser menor nas mulheres que nos homens fazendo com que uma maior quantidade de álcool ingerida chegue até o fígado, causando prejuízos mais rapidamente (MANCINELLI; BINETTI; CECCANTI, 2007). Além disto, autores sugerem que a atividade desta enzima varia de acordo com a idade, sendo que em mulheres de 20 a 40 anos a atividade é mínima, já entre os 40 e 60 anos ela atinge seu máximo e decresce após os 60 anos (PARLESAK et al, 2002). De acordo com a literatura biomédica, estes fatores levariam as mulheres a sentirem os efeitos das bebidas alcoólicas com maior rapidez e intensidade do que os homens, precisando de menores quantidades de álcool para conseguir os mesmos efeitos. Em relação aos efeitos, também sugere que as mulheres sentiriam mais os efeitos negativos do álcool, 
como dores de cabeça, e por isto, beberiam menos que os homens (WILSNACK; WILSNACK; OBOT, 2005).

Os autores apontam que as mulheres desenvolvem a dependência mais rapidamente que os homens, assim como, devido a maior vulnerabilidade dos tecidos, elas teriam maior tendência a terem cirrose hepática e miocardiopatias (NOLENHOEKSEMA, 2004; MADRIGAL, 1993). Um estudo realizado em Ribeirão Preto - SP, relatou que a média do tempo de alcoolismo para o aparecimento de cirrose hepática nas mulheres foi de 14,62 anos, sendo que entre os homens foi de 21,10 anos (DANTAS, 1985). É o que a literatura chama de "efeito telescópio", nome dado ao processo de adoecimento rápido que relata acontecer com as mulheres dependentes de álcool quando comparadas com os homens dependentes. Isto as levaria a procurar tratamento mais rapidamente que os homens. Ao chegarem para o tratamento, comparando-as aos homens, mesmo que tenham bebido por menos tempo que eles, os danos seriam iguais (HERNANDEZ-AVILA; ROUNSAVILLE; KRANZLER, 2004; KINGA; BERNARDY; HAUNER, 2003).

A literatura também sugere que o cérebro da mulher seria mais vulnerável à toxidade do álcool que o dos homens. Pesquisadores disseram ter encontrado algumas alterações no cérebro de mulheres alcoolistas que não se apresentavam no cérebro de mulheres não alcoolistas. Estas mesmas alterações não foram encontradas no cérebro de homens alcoolistas (MANCINELLI; BINETTI; CECCANTI, 2007). Relata também que as mulheres sofrem maiores prejuízos cognitivos (na resolução de problemas, em testes neuropsicológicos e motores) devido ao uso de álcool que os homens, ou então, que estes prejuízos ocorreriam mais rapidamente que em homens (NOLEN-HOEKSEMA, 2004).

Desta forma, o discurso biomédico, constrói o consumo de bebidas alcoólicas por mulheres como mais danoso do que o consumo feito por homens. Os estudos apresentados aqui explicam que devido a diferenças fisiológicas, os prejuízos físicos seriam maiores e mais rápidos nas mulheres, além de que estas desenvolveriam a dependência mais rapidamente. Assim, as mulheres beberiam menos que os homens por sentirem mais rapidamente os efeitos negativos. Um dos efeitos deste discurso é a criação de políticas de prevenção voltadas especialmente para o público feminino, considerado mais vulnerável.

Algo que não foi encontrado na literatura biomédica analisada aqui diz respeito à rede social da mulher que bebe de modo considerado problemático. Quantas pessoas há ao redor de um homem que bebe? É comum encontrarmos uma esposa preocupada, que obriga o marido a se alimentar bem, cuida para que ele tenha uma certa rotina e até dá uma desculpa para que ele não seja despedido do trabalho. Ou então uma mãe que freqüenta grupos de auto-ajuda, ou filhas que querem saber como podem ajudar o pai, 
ou filhos que buscam o pai embriagado e protegem-no de brigas. Quantas pessoas há ao redor de uma mulher que bebe? É muito raro encontrar um marido que já não a tenha abandonado, ou uma mãe que já não a tenha renegado, ou um filho que não a culpe por não ser boa mãe. Nossa experiência nos mostra que geralmente estas mulheres estão tendo que se cuidar sozinhas e, muitas vezes, cuidar também do esposo que bebe. Será que esta questão poderia influenciar o "efeito telescópio"? Entretanto, um dos possíveis efeitos do discurso biomédico é o de individualizar as causas do consumo e do adoecimento, colocando-as como conseqüência da constituição do corpo da mulher. Corpo este já tradicionalmente tratado como mais frágil e a mercê de alterações hormonais. Desta forma, as políticas públicas voltadas para esta população provavelmente serão individualizadoras e colocarão como responsabilidade da mulher tomar conta de seu corpo.

Para aguçar esta discussão, proponho um olhar sobre as idéias de Vieira (2002). A autora, estudando a medicalização do corpo feminino, coloca que a biologia vem sendo historicamente utilizada no controle do corpo feminino e na definição do papel social da mulher. Desta forma, desde o século XIX, a medicina vem investindo na educação das mulheres para se tornarem boas reprodutoras e formar boas mães, garantindo a sobrevivência e saúde das crianças. A autora também coloca que o discurso da medicina vem amparado por estudos da ciência positivista, que busca mostrar-se de modo neutro e objetivo. Entretanto, na teia que se forma entre medicina e sociedade, produz-se conhecimentos embasados e para embasar os projetos de sociedade.

Isto talvez nos ajude a entender o que foi apresentado no início deste capítulo, sobre o número extenso de estudos sobre o uso de álcool pela mulher em que o foco é o feto e não a mulher. Os estudos apontam para os danos que o álcool pode causar à saúde reprodutiva e à prole. A literatura coloca que exatamente no período em que a mulher está fértil (entre os 20 e 40 anos) seria também o período onde a enzima álcool desidrogenase tem atividade mínima, aumentando a exposição da mulher e do feto aos efeitos tóxicos do álcool. Além disto, estudos descrevem que o uso abusivo de álcool reduz a fertilidade entre mulheres e aumenta o risco de deformidades e complicações ao feto (NOLEN-HOEKSEMA, 2004). Existe ampla literatura descrevendo a Síndrome Alcoólica Fetal (SAF), causada pelo consumo de álcool durante a gestação. No recém nascido, a SAF teria manifestações craniofaciais (como microcefalia), no sistema nervoso central (como anormalidades neurológicas) e no crescimento (como baixo peso e/ ou retardo no crescimento). A criança com SAF teria o desenvolvimento prejudicado, podendo ter retardo mental, déficit da performance de habilidade verbal, dificuldades de concentração, diminuição da captação de informações, hiperatividade e déficit cognitivo (SOKOL; CLARREN, 1989). Frente a estas descrições, pesquisadores sugerem que atenção especial seja dada à gestante em relação ao consumo de bebidas alcoólicas, no 
intuito de prevenir o impacto de danos à gestante e ao bebê (PINHEIRO; LAPREGA; FURTADO, 2005). Com base nestes discursos, são oferecidas capacitações a profissionais de saúde que lidam diretamente com gestantes, para que saibam identificar o consumo de álcool e saibam como manejar os casos positivos (PAI-PAD, 2009). Mostrando que estes discursos chegam até as mulheres, um estudo relatou que as mulheres consideradas alcoolistas, preocupadas com o consumo durante a gestação, afirmaram que o momento da vida em que tiveram maior controle sobre o beber foi no período da gravidez e da amamentação dos filhos (CESAR, 2006).

Além de estudos que produzem discursos sobre causas e conseqüências clínicas do uso de álcool por mulheres, a literatura também apresenta discursos sociológicos, que buscam compreender o consumo de álcool por mulheres através do estudo das influências do meio e das relações sociais. Este aparece muitas vezes ancorado ao discurso dos papéis sociais de gênero, que constroem um conjunto de comportamentos considerados masculinos e femininos e também ao discurso feminista, que segundo Pinto (2004, p. 108) refere-se a "sentidos produzidos por posições ideológicas colocadas em jogo na luta contra as desigualdades entre homens e mulheres" (WILSNACK et al, 2000; ETTORE, 2007; ETTORRE, 1997).

Com o uso do discurso dos papéis sociais tradicionais de gênero, alguns estudos apontam que as mulheres beberiam menos que os homens por se sentirem mais incomodadas que estes com a idéia de perderem o controle sobre seus comportamentos e de se colocarem em risco, evitando portanto, o consumo de álcool que as expusesse a estas situações (WILSNACK; WILSNACK; OBOT, 2005). A literatura descreve os homens como sendo mais motivados que as mulheres a assumirem riscos, seja por sentirem mais prazer no risco do que as mulheres ou porque ao se colocarem em risco têm a oportunidade de provarem sua masculinidade. O consumo de álcool ajudaria os homens nesta empreitada, encorajando-os a aderir a outros comportamentos de risco, como o envolvimento em brigas (NOLEN-HOEKSEMA, 2004).

De acordo com estes discursos, o consumo de álcool seria algo usado em diversas sociedades para diferenciar e regular os papéis de gênero (ETTORRE, 2007; WILSNACK; WILSNACK; OBOT, 2005). Sendo construído como uma demonstração de masculinidade em algumas sociedades, o uso de álcool seria visto como fazendo parte do mundo dos homens. Sua proibição entre as mulheres também simbolizaria a submissão destas, sendo um modo de controle de seus comportamentos e ajudando a prevenir uma maior autonomia sexual da mulher que poderia resultar da intoxicação. A literatura coloca que tanto homens como mulheres teriam expectativas de que o álcool melhoraria seu desempenho sexual e deixa-los-ia mais liberados sexualmente. Desta forma, em sociedades em que o consumo é considerado símbolo da masculinidade, força e camaradagem haveria uma tendência de não se preocupar tanto com os problemas 
decorrentes do uso excessivo (WILSNACK; WILSNACK; OBOT, 2005). A literatura destaca que ao simbolizar o poder dos homens sobre as mulheres, o álcool se tornaria um emblema da superioridade masculina, um privilégio reservado a eles e negado às mulheres, mostrando o status privilegiado dos homens frente às mulheres. Além disto, diz que nas construções de gênero de nossa sociedade, é papel da mulher cuidar da casa e da família, tendo uma função importante para a socialização, para a organização da estrutura familiar e com isto, da sociedade. Deve, portanto estar sóbria e consciente de seus atos e responsabilidades, não podendo consumir álcool em quantidades excessivas (AMES; REBHUN, 1996). Somando-se a isto, em algumas sociedades, a literatura observa que é esperado que a mulher assuma o papel de controle do consumo de álcool de seus maridos, tendo portanto mais motivos para permanecerem sóbrias (ALLAMANI, 2008).

Um dos efeitos destes discursos é a construção do consumo de álcool por mulheres como modo de se emanciparem, de conquistarem os mesmos direitos dos homens, tornando-se donas de seus corpos e gerentes de seus comportamentos. Neste caso, o consumo poderia ganhar o sentido de busca por igualdade de gênero. Como ilustração trago uma experiência de coordenação de uma oficina de gênero ocorrida em 2005, em Ribeirão Preto. Naquela ocasião, foi preparada uma atividade de aquecimento com mulheres do acampamento, a fim de trabalhar questões relacionados ao gênero. Diversos objetos foram levados, foram feitos dois círculos no chão e pediu-se que colocassem objetos que representavam os homens no círculo da esquerda, as mulheres no círculo da direita e ambos no centro. Entre os objetos havia uma garrafa de pinga. Uma das mulheres pegou a garrafa e ficou em dúvida de onde colocá-la, decidindo pelo círculo da esquerda (homens). Foi imediatamente repreendida por suas colegas, que disseram que a garrafa deveria ser colocada no centro, alegando que beber também era um direito das mulheres. Ficaram muito bravas com a colega que havia sugerido o círculo dos homens e disseram que poder beber pinga era uma conquista que tinham alcançado como parte de suas lutas. Com isto, percebemos um novo discurso sendo construído, o discurso de consumo de álcool como igualdade de gênero.

Entretanto, este discurso parece não ser hegemônico. A mulher que abusa de bebidas alcoólicas sofre mais discriminação social que os homens, principalmente as mais velhas, sendo também mais rejeitadas pela família (ETTORRE, 2007; ALLAMANI et al., 2000). Este julgamento social rígido estaria relacionado com os efeitos indesejáveis socialmente, como apetite sexual aumentado ou diminuído e maior vulnerabilidade para o abuso sexual. Como estes efeitos são incompatíveis com o discurso dos papéis sociais esperados para as mulheres, estas ficariam mais vigilantes em relação ao consumo de álcool (KERR-CORRÊA et al, 2007). Para Ettorre (1997), socióloga feminista, é como se a sociedade dissesse "Uma boa menina não bebe muito!" e ao consumir, a mulher estaria 
dizendo um grande "Não!" para a sociedade e fazendo o que é inaceitável: perdendo o controle. A sociedade então a encararia como se ela tivesse fracassado como mulher. Com medo de ser punida, perder a custódia de seus filhos ou ficar longe devido a uma internação, a mulher restringiria o consumo a situações mais privadas e escondidas.

A fim de identificar a percepção das mulheres sobre as sanções sociais, um estudo perguntou a mulheres sobre como seria a desaprovação social de um homem ou de uma mulher intoxicada. Dentre as participantes, 50\% achavam que outras pessoas desaprovariam que uma mulher ficasse intoxicada em uma festa, enquanto $30 \%$ achavam que o mesmo ocorreria caso fosse um homem (WILSNACK, $1996^{5}$ apud NOLENHOEKSEMA; HILT, 2006).

O casamento, a maternidade e o emprego também são descritos como tendo um efeito desencorajador sob o consumo de álcool das mulheres, enquanto o fato de serem solteiras, divorciadas, estarem desempregadas e não terem filhos parecem aumentar o risco para o consumo abusivo. Com isto, alguns autores concluem que quanto menos papéis sociais a mulher tiver que desempenhar e menos responsabilidades tiver, maior será o risco de fazer uso problemático de álcool (VOGELTANZ; WILSNACK, $1997^{6}$ apud KERR-CORRÊA et al., 2007).

Através da análise destes estudos, percebe-se que o discurso dos papéis sociais de gênero também tem outro efeito: ao construir o consumo de bebidas alcoólicas como comportamento masculino, constrói em algumas mulheres que bebem o sentimento de culpa e vergonha, levando-as a evitar o consumo público e a esconder este comportamento de outras pessoas.

Apesar das conseqüências físicas causadas pelo consumo de álcool e de todas as sanções sociais que buscam controlar o consumo entre as mulheres, parece que este vem aumentando nos últimos anos. Para compreender este aumento, a literatura utiliza o discurso dos fatores de risco, que afirma que existem alguns fatores associados ao aumento do risco de se desenvolver determinada doença.

Alguns autores sugerem que os padrões hormonais das mulheres representam um importante papel no aumento da vulnerabilidade destas ao álcool (MANCINELLI; BINETTI; CECCANTI, 2007), trazendo indicações de que o consumo de álcool pode variar de acordo com o ciclo menstrual, havendo um aumento do consumo de bebidas alcoólicas entre as mulheres alcoolistas durante o período pré-menstrual. Como efeito deste discurso, é recomendado aos profissionais de saúde que assistem essas mulheres a ficarem atentos a maiores possibilidades de recaídas neste momento (ALLEN, 1996).

\footnotetext{
${ }^{5}$ WILSNACK, S. C. Women's perceptions about the social acceptability of women's versus men's drinking. Unpublished raw data. University of North Dakota School of Medicine and Health Sciences. Grand Folks, ND, 1996.

${ }^{6}$ VOGELTANZ, N.; WILSNACK, S. 1997. Alcohol problems in women: risk factors, consequences, and treatment strategies. In: GALLANT, S.; KEITA, G.; ROYAK-SCHALER, R. (eds.). Health Career for Women: Psychological, Social, and Behavioral Influences. Washington: American Psychological Association, p. 75-96.
} 
Entretanto, esta posição não é unânime, já que alguns estudos não encontraram associação entre o aumento do consumo de álcool com os sintomas da síndrome prémenstrual (SVIKIS et al, 2006).

Influenciado pelo discurso médico-psiquiátrico, outro fator muito estudado na literatura refere-se às comorbidades psiquiátricas. Entre as mulheres destaca-se a associação do álcool com sintomas de depressão, de ansiedade e transtornos alimentares (KERR-CORRÊA et al., 2007; PINHEIRO; LAPREGA; FURTADO, 2005; KINGA; BERNARDY; HAUNER, 2003). Uma das explicações para isto seria a de que as mulheres consumiriam bebidas alcoólicas a fim de aliviar estes sintomas, já que elas parecem apresentar problemas psiquiátricos antes do tratamento para a dependência de álcool (HERNANDEZAVILA; ROUNSAVILLE; KRANZLER, 2004).

Entretanto, o fato do álcool ser utilizado como medicamento para um transtorno ou sintoma psiquiátrico vem começando a ganhar certo respaldo da literatura. Para Éttorre (1997), todas as sociedades têm seus processos de amortecimento, ou seja, modos como as pessoas lidam com o estresse indesejável. Em nossa sociedade este processo seria preservado pela venda legal e ilegal de substâncias, aditivas ou não. Para a autora, atualmente tornou-se prática comum tomar algo para aliviar o estresse, a tristeza e a ansiedade do dia a dia, devendo portanto ser aceito que a mulher consuma bebidas para se sentir melhor. Nesta mesma direção, Van Tilburga \& Vingerhoets (2002) apontam que alguns experimentos feitos com mulheres mostram que o consumo de álcool parece ter efeitos ansiolíticos e reduzir o impacto emocional do estímulo estressor, além de melhorar o humor, trazendo, a curto prazo, alívio para qualquer estado de humor negativo. Isto reforçaria na mulher o hábito de beber quando exposta a uma situação estressante. Os autores destacam que o humor negativo (depressão e ansiedade) é construído, em nossa sociedade, como doença, enquanto o humor positivo estaria associado à saúde. Com isto sugerem que, trazendo alívio para a ansiedade e melhorando o modo como a mulher aproveita sua vida, o consumo de álcool pode ser construído como tendo um efeito positivo sobre a sua saúde. Concluem dizendo que o consumo moderado poderia ser construído como um modo legítimo de regular as emoções e lidar com o estresse.

O discurso médico-psiquiátrico vem ancorado ao discurso da medicalização, que define comportamentos e experiências humanas como problemas médicos, tendo, portanto, que ser tratados por um profissional de saúde (TESSER, 2006). Desta forma, o modo encontrado por estas mulheres para lidarem com o humor negativo não seria legítimado, já que apenas o médico estaria autorizado a indicar o uso de uma determinada droga. Para contribuir nesta reflexão trago um exemplo utilizado por Foucault sobre os peregrinos de Lourdes. O autor coloca que podemos considerar esta peregrinação como resíduo de crenças arcaicas que ainda não desapareceram, mas 
sugere olhar para elas como uma forma de resistência difusa ao discurso da medicalização, que de modo autoritário e com o uso de mecanismos que o legitimam como "verdade", vem controlando corpos e pessoas. Podemos utilizar este exemplo de Foucault par refletir a respeito do discurso da comorbidade? O efeito do discurso da comorbidade seria aproximar a mulher que bebe de profissionais de saúde que the diriam quais substâncias pode consumir para lidar com suas emoções. Este efeito pode ser libertador, diminuindo o sofrimento de mulheres que se sentem estigmatizadas por consumirem bebidas alcoólicas, possibilitando que estas se insiram socialmente com o uso de outras substâncias que ganham legitimidade por serem recomendadas por um médico. Entretanto, pode também aprisionar a mulher a uma outra substância ou tratamento, que a descreverá como alguém que não tem controle e agenciamento, precisando ser cuidada por outros.

O histórico de violência também vem sendo apontado como uma dos fatores de risco para o consumo abusivo. A literatura sugere que mulheres que sofreram maus tratos e violência na infância e na vida adulta parecem ter mais problemas com bebidas alcoólicas (KERR-CORRÊRA et al., 2007; CESAR, 2006; NOLEN-HOEKSEMA, 2004). Mesmo entre mulheres grávidas, estudos mostram uma associação entre uso de álcool durante a gestação e ter sido violentada fisicamente no último ano. Esta relação é bastante discutida, já que o uso de álcool pode tanto ser feito em conseqüência da violência, como pode ter facilitado a violência (HAYNES; DUNNAGAN; CHRISTOPHER, 2003). Estudo realizado com lésbicas, também aponta que o abuso sexual na infância parece ser importante preditor para o abuso de álcool na idade adulta (HUGHES et al., 2007). Entretanto, alguns estudos contrapõem esta visão. Estudo realizado para detectar a associação entre vitimização sexual e o uso de álcool não encontrou dados que sustentassem esta afirmação. Os autores sugerem que "o uso pesado de álcool é relativamente estável no decorrer do tempo e a vitimização sexual não tem uma contribuição substancial independente para o consumo pesado entre mulheres da população geral" (TESTA; LINVINGSTON; HOFFMAN, 2007, p. 2936). Outra observação encontrada na literatura sobre os estudos que apontam esta relação diz que a violência associada ao uso de álcool vem sendo tratada em seus aspectos genéricos, sem especificar a gravidade, a freqüência ou nível de comprometimento dos papéis sociais (SIMÃO et al., 1997; TESTA; PARKS, 1996).

A influência dos parceiros também aparece descrita como importante fator de risco no consumo de álcool entre as mulheres. As mulheres seriam influenciadas por seus parceiros que abusam de álcool para iniciar, aumentar e manter o consumo de bebidas, além de que estes poderiam desmotivá-las a procurar o tratamento (KERR-CORRÊA et al., 2007; BRASILIANO, HOCHGRAF; 2006; RUBIN; STOUT; LONGABAUGH,1996). Deste 
modo, parece que em muitas situações é o homem quem autoriza ou desautoriza o consumo de álcool feito por mulheres.

Ainda com o uso do discurso dos fatores de risco, a literatura oferece diversos estudos que apontam fatores culturais. Aqui encontramos novamente o discurso dos papéis sociais de gênero, referindo-se, mais especificadamente, à mudança de alguns papéis sociais das mulheres. As mulheres estariam assumindo papéis que anteriormente cabiam apenas aos homens, como aqueles relacionados à ocupação do espaço público (ex. trabalho fora do lar). Estas mudanças poderiam ter encorajado as mulheres a adotarem também outros comportamentos que antes eram permitidos apenas aos homens, como o uso de bebidas alcoólicas (hipótese da convergência). Apesar das mulheres estarem assumindo estes novos papéis, continuariam geralmente com as tarefas domésticas, ficando com isto sobrecarregas e estressadas, o que a literatura também considera como fator de risco para o consumo de álcool (ROXBURGH, 1998; MADRIGAL, 1993). Entretanto, este argumento não é um consenso na literatura. Ames \& Rebhun (1996) ponderam que a visão do consumo de álcool por mulheres deve ser considerada dentro de um contexto maior de subordinação política e social, em que os pesquisadores, assim como seus objetos de estudo, são influenciados. Para estes autores isto se refletiria na literatura que muitas vezes, ao teorizar sobre a mulher, o álcool e o trabalho, assume uma postura moralizante, "tanto ao tratar qualquer consumo como danoso à mulher como ao afirmar que o trabalho fora de casa aumentaria as chances de consumirem álcool (por ser algo tão diferente à mulher causaria estresse ou a aproximaria do mundo profano dos homens)." (AMES; REBHUN,1996, p. 1650). Os autores relatam que há alguns estudos que mostram que o consumo de álcool entre as mulheres também parece ter aumentado entre aquelas que continuam no espaço privado do lar, em atividades predominantemente domésticas e que mesmo entre o grupo de mulheres com atividades similares às masculinas, o consumo ainda é menor que entre os homens. Para Möller-Leimkühler et al. (2002), o fato de ser dona de casa pode ser fator de risco para algumas mulheres enquanto para outras, trabalhar fora pode ser um fator protetor. Parece não ser possível afirmar que o trabalho fora do lar influencia no modo como as mulheres bebem, já que existem outros fatores influenciando além do trabalho (familiares, étnicos, culturais...). Mesmo considerando-se apenas o trabalho, a literatura destaca que não é apenas o fato de trabalhar fora que influencia, mas a cultura do ambiente de trabalho. Os autores também sinalizam que este argumento deve ser tratado com cuidado, já que pode servir para a manutenção do papel da mulher restrito ao lar.

Há outras hipóteses na literatura que buscam utilizar o discurso dos papéis sociais de gênero para compreender o uso de álcool. Uma delas entende que a identificação com os papéis sociais tradicionais de gênero feminino seria um fator protetor, já que a mulher 
estaria longe do mundo dos homens e do álcool. A outra hipótese percebe a questão de forma inversa, vendo que esta identificação seria um fator de risco. Frente às mudanças ocorridas na sociedade, estas mulheres teriam poucas habilidades de enfrentamento, tendo dificuldades para lidarem com as demandas atuais de autonomia e usando o álcool a fim de aumentar a auto-estima e compensar os déficits de enfrentamento. De acordo com esta hipótese, a identificação com papéis sociais tradicionalmente masculinos poderia ser um fator protetor ao consumo de álcool (MÖLLER-LEIMKÜHLER et al, 2002). Ettorre (1997) destaca dois significados relacionados à palavra dependência: subordinação e adição. Enquanto o primeiro sempre foi incentivado para as mulheres, o segundo foi condenado. Entretanto, coloca que o segundo pode ser causado pelo primeiro. Frente a isto, com o maior acesso às bebidas alcoólicas e com maior liberdade para consumi-las, o consumo entre as mulheres pode ser considerado como um aspecto positivo, representando a liberação destas de estruturas sociais opressivas (MÖLLERLEIMKÜHLER et al, 2002).

O discurso psicológico, que tradicionalmente vem sendo utilizado para estudar comportamentos e processos mentais, também aparece presente na literatura, descrevendo algumas características psicológicas das mulheres que fazem uso abusivo de álcool. Elas são descritas como tendo auto-imagem negativa, lócus de controle externo, grande autocrítica e consumindo bebidas alcoólicas em momentos em que se sentem inadequadas e desempoderadas (MOOS; MOOS; TIMKO, 2006; AUBRY et al, 2004). Elas teriam mais histórico de tentativas de suicídio e usariam menos drogas ilícitas que os homens (HOCHGRAF; ZILBERMAN; ANDRADE, 1995).

Para Ettorre (1997), as mulheres que bebem de modo abusivo tendem a ter dificuldades para confrontar suas emoções frente ao estigma social. A mulher dependente teria uma "vergonha internalizada", já que quanto mais ela se torna dependente, mais difícil é para ela resolver seus problemas e olhar para si sem sentir vergonha. Para a autora, a sociedade as consideraria como "aleijadas emocionalmente". Apesar dos homens também sofrerem este estigma, ele é maior entre as mulheres, já que a sociedade espera que as mulheres saibam lidar com suas emoções e sentimentos, saibam controlá-los e suportem pressões e dificuldades. As mulheres que abusam de álcool seriam, portanto, mulheres fracassadas. A autora lembra que no discurso da feminilidade, a mulher é colocada como aquela que é sensível e aberta a si mesmo e a sua família, falando mais sobre suas emoções e sendo mais emotiva. A emotividade feminina explicaria sua força e suas fraquezas, estando ligada a sua capacidade de lidar com as dificuldades do dia a dia e de ser a cuidadora da casa. É como se a mulher que bebesse demais estivesse falando um grande "Não!" para a sociedade no que se refere ao seu papel de saber lidar com as emoções. Só que o modo escolhido traria mais 
humilhação, desempoderaria e alienaria, construindo descrições de sentimentos de culpa e vergonha.

Quanto à vida social destas mulheres, elas são descritas como tendo dificuldades de estabelecer relações saudáveis e significativas, com destaque para dificuldades no relacionamento na infância e na adolescência, principalmente com outras mulheres, entre elas a mãe. A literatura aponta que estas têm sentimentos de isolamento, de não pertencimento, de desligamento de pares e de grupos sociais. Por não se sentirem amadas por seus familiares teriam grande necessidade de se sentir queridas, cuidadas e amadas, necessidades estas que influenciariam no abuso de substâncias (MASTERS; CARLSON, 2006).

Os danos causados pelo uso abusivo de álcool para a vida social das mulheres são descritos como inúmeros. Ettorre (1997) coloca que o uso de álcool parece afetar o relacionamento com o companheiro, com filhos, com pais, com vizinhos, dentre outros. Além disto, também constrói diversos sentimentos e comportamentos nas pessoas ao redor. Estes sentimentos podem incluir raiva, desprezo, nojo, dó e empatia e as respostas podem vir como silêncio, críticas, conselhos e rejeição. As pessoas próximas sentem que não podem fazer nada para ajudar na mudança e dizem que ela precisa encontrar forças dentro dela para parar de beber.

Entretanto, os relacionamentos familiares onde existe coesão, harmonia, pouca discordância verbal e pouco conflito são descritos como fatores protetores (JENNISON; JOHNSON, 2001. NEVE et al, 1996). Além disto, acreditar que o uso de álcool pode afetar negativamente o relacionamento conjugal parece inibir o consumo entre as mulheres, já que estas tenderiam a zelar pelos relacionamentos (KELLYA; HALFORDB; YOUNG, 2002).

Um dos efeitos do discurso psicológico é o convite a refletir sobre o consumo de álcool como algo relacionado a características da personalidade, que precisam ser trabalhadas para que o consumo cesse. Miller e Rollnick (2001) destacam que muitos grupos e profissionais que trabalham com usuários de álcool compreendem que alcoolistas têm alguns traços específicos de personalidade. Os autores apontam para a influência do discurso psicodinâmico compreendendo os problemas com álcool como sintomáticos de um transtorno de personalidade, descrevendo os alcoolistas como pessoas que utilizam excessivamente alguns mecanismos de defesa primitivos, como negação, racionalização, regressão e projeção. Para os autores, um dos efeitos deste discurso é a estigmatização desta população, que passa a ser considerada como diferente das "pessoas normais". Sendo diferentes, podem receber atendimento diferenciado. Esta construção levou a criação de estratégias confrontacionais agressivas para a abordagem desta população, como meio de quebrar estas defesas. Recentemente, a mídia vem divulgando espaços que oferecem assistência a usuários de álcool e outras drogas que utilizam estratégias altamente agressivas, que nunca seriam aceitas para uso com outros 
pacientes. Entre profissionais de saúde também há diversos estudos que mostram que o atendimento oferecido a esta população é diferente do oferecido a população geral, por entenderem que pessoas que bebem têm características de personalidade duvidosas e que talvez, sendo mal atendidos, farão alguma mudança.

O discurso da literatura psicológica analisada pode ser um convite à construção de outros modos de se relacionar e ser no mundo ou ser um convite a cristalizar descrições identitárias, dificultando as mudanças.

Os discursos utilizados pela literatura a respeito do consumo de álcool por mulheres apontam para a riqueza do tema. Como dito anteriormente, os discurso têm uma característica chamada por Iñiguez (2004) de intertextualidade, ou seja, não estão sozinhos, são ancorados a outros discursos. Deste modo, vemos que a literatura nos apresenta uma teia, onde os diferentes discursos se entremeiam e se constroem. Entretanto, o discurso dos papéis sociais de gênero aparece associado aos diversos outros, dentre eles ao epidemiológico, médico-psiquiátrico e psicológico.

Nesta riqueza de descrições, o mesmo aspecto aparece construído por diferentes perspectivas (ex. relação entre violência e consumo, relação entre trabalho e consumo). Entretanto, percebemos a tendência, mesmo nos estudos feministas, de narrar sobre mulheres vitimizadas pela vida, estigmatizadas pelo consumo, criticadas por familiares e amigos e envergonhadas. É assim que a literatura constrói o objeto "mulheres que consomem bebidas alcoólicas". Talvez pelos estudos privilegiarem a inclusão de mulheres que tiveram o consumo de bebidas alcoólicas construído em seus relacionamentos como um problema. São, muitas vezes, mulheres que encontramos nos serviços especializados para o manejo de problemas relacionados ao uso de álcool e outras drogas, em grupos de auto-ajuda, em ambulatórios psiquiátricos, em hospitais gerais e em equipamentos do serviço social. São mulheres que merecem a atenção, já que relatam sofrimento e, muitas vezes, desejo de fazer mudanças. Entretanto, este não é o único jeito de descrever mulheres que consomem bebidas alcoólicas. No campo de estudos de álcool e outras drogas, há uma tendência dos pesquisadores de abordarem a questão sempre como problema. Kuhn (2003) nos proporciona uma importante discussão a respeito dos paradigmas científicos, apontando que as diferentes práticas científicas oferecem modelos que são disseminados e criam formas particulares de tradições na pesquisa científica. Desta forma, ao assumir determinado paradigma, o pesquisador se torna membro de uma comunidade científica em particular, que terá critérios estabelecidos para a escolha das questões de pesquisa, para o processo de investigação destas questões e para a forma como elas serão respondidas.

No campo de estudo de álcool e outras drogas, observamos que são raras as questões de pesquisa que buscam conhecer possíveis benefícios advindos do consumo, como por exemplo, como o álcool pode ajudar algumas pessoas a resolver questões 
importantes em suas vidas. Dentro do paradigma adotado por nossa comunidade científica, as pesquisas relacionadas ao uso de álcool concentram-se predominantemente em conhecer os prejuízos causados por ele e em como prevenir e tratar este consumo e estes prejuízos.

Nutt (2009) aponta para a dificuldade de se obter financiamento para estudos que sugerem que determinada substância pode também trazer benefícios ou não causar tantos prejuízos como os preconizados. Sem financiamento, estudos não podem ser realizados e a impressão passada para o público em geral, é a de que todo e qualquer consumo é problemático. Desta forma, a literatura deixa de lado mulheres que são bem sucedidas profissionalmente e bebem, mulheres que vivem um relacionamento feliz e bebem, mulheres que bebem e não se envergonham disto. Este é um campo de estudo praticamente desconhecido. Entretanto, nossas práticas nos mostram que estas mulheres também existem, entretanto, não existem para a literatura. Há uma tendência entre os pesquisadores, a abordar a questão tomando como ponto de partida o problema. Os estudos parecem já iniciar com as questões: "vamos descobrir as causas deste problema", "vamos estudar as conseqüências deste problema", "vamos conhecer a extensão deste problema", "vamos planejar como prevenir este problema", "vamos conhecer o impacto deste problema". Em nossa sociedade atual, o consumo de álcool, ou de outra substância psicoativa (com exceção das de uso medicamentoso) parece já ter sido construído pela ciência como problemático.

Vemos na prática clínica, diversas pessoas que sofrem e desejam mudar o modo como consomem substâncias, entre elas, mulheres que querem parar de beber ou, que querem parar de sofrer. Poderíamos nos beneficiar com estudos que buscassem, entre mulheres que não têm o consumo construído como problema, os discursos que legitimam e regulam este consumo. Para isto, precisamos, no campo de estudo de álcool e outras drogas, passar pelo que Kuhn (2003) chamou de "transição paradigmática", reconstruindo o campo de estudo, abrindo espaço para que outras vozes e outros discursos contribuam para a discussão da questão e deste modo, auxilie na abertura de novas possibilidades. Enquanto pesquisadores, temos que nos engajar em um processo reflexivo, analisando os discursos que estamos utilizando e refletindo sobre em quais outros discursos estes se ancoram. Será que estão ancorados no discurso biomédico, no discurso dos papéis sociais de gênero, no discurso da moral, no discurso religioso, no discurso psicológico,...? Compreendendo a linguagem como construtora da realidade, quais efeitos podem ser causados por nossos discursos? Estão sendo generativos? Estão nos abrindo possibilidades de ampliar reflexões sobre o campo? Estão nos aproximando dos usuários? 



\section{OBJETIVOS}

O discurso construcionista social vem contribuindo para o estudo das construções de sentidos em saúde, mostrando-se como um discurso útil para auxiliar na abertura de novas possibilidades de construção dos fenômenos e convidando os pesquisadores e leitores a questionarem o conhecimento tomado como óbvio. O campo de estudos sobre o consumo de bebidas alcoólicas por mulheres ainda é novo, necessitando de estudos que tenham sensibilidade para as questões de gênero e que se comprometam a produzir um conhecimento que seja útil às mulheres usuárias de álcool, contribuindo para a diminuição dos estigmas e ajudando no empoderamento destas. Com este estudo, propomos um diálogo entre o discurso construcionista social e o campo de estudo de uso de álcool por mulheres, tendo como interlocutores deste diálogo a literatura da área e entrevistas com mulheres que fizeram tratamento pelo consumo de álcool. Para orientar esta proposta, contamos com os seguintes objetivos:

\section{Objetivo geral:}

Fazer uma aproximação do discurso construcionista social para o campo de estudos do consumo de bebidas alcoólicas por mulheres.

\section{Objetivos específicos:}

- Problematizar o vocabulário disponível na área para a significação das situações referentes ao uso de álcool.

- Analisar as implicações identitárias dos discursos tradicionais da área.

- Produzir interpretações alternativas relativas às questões de uso do álcool (individual e social). 

Capítulo 3

Percurso metodológico 



\section{Delineamento teórico-metodológico da pesquisa}

Este estudo foi realizado de modo qualitativo, descritivo, tendo como referencial teórico o discurso construcionista social. A escolha do método qualitativo se deu por este ser ideal para a coleta de informações lingüísticas e textuais, havendo menos chance de descontextualizar a experiência e os relatos dos participantes (BURR, 2003). Além disto, o campo de estudo de álcool e outras drogas parece ainda carente de literatura que explore qualitativamente e com profundidade o tema, trazendo para discussão uma posição simpática/empática (ETORRE, 2007).

Ao usar o discurso construcionista social como referencial teórico deste estudo, esta pesquisa teve como foco a linguagem, entendendo-a como construtora da realidade (BURR, 2003). Com o uso da linguagem as pessoas constroem versões do mundo social e de si mesmas, sendo estas construções relacionais (POTTER, WETHERELL;1987). Entende-se, portanto, que existem múltiplas formas de descrever algo, múltiplas realidades. Desta forma, a pesquisa é vista como um processo que implica na construção e reconstrução de descrições da vida social, sendo uma co-produção entre o pesquisador e o pesquisado, considerados aqui como pessoas imersas em outros múltiplos relacionamentos, trazendo para a pesquisa seus diálogos (MCNAMEE, 2009). De Shazer, falando sobre a linguagem, nos diz que ao invés de olhar para além das palavras, devemos olhar as palavras. De acordo com ele, nem o autor, nem o falante (speaker), nem o leitor, nem o ouvinte podem dizer que sabem com certeza o que está sendo 'realmente' dito, já que cada um traz para o encontro suas experiências prévias e constroem os significados na interação. Desta forma, o significado é negociado em contextos específicos.

E é com a perspectiva de convite ao diálogo que a pesquisa construcionista trabalha. Pretende-se com o estudo propiciar um diálogo contínuo através do qual os participantes vão sendo construídos, deixando ao leitor, a possibilidade de fazer outras construções (FRANK, 2005).

O pesquisador construcionista social, ao selecionar um tema de estudo, assume que está ajudando a construir este tópico, estando, portanto atento às implicações do processo, desde a coleta de dados até a divulgação dos resultados.

Com isto, torna-se responsabilidade do pesquisador a descrição e a exploração plena do contexto da pesquisa, garantindo a indexicalidade, ou seja, a vinculação da pesquisa ao contexto (SPINK, 2004). Potter \& Wetherrel (1987) ilustram a indexicalidade com o seguinte exemplo: a afirmação "o dia está bonito hoje!" pode ser usada para chamar a atenção para um dia ensolarado ou, de modo irônico, para um dia chuvoso. Para os autores, grande parte de nossas expressões são indexais, ou seja, têm significados diferentes de acordo com o contexto ou ocasião de uso. Quando partilhamos 
de uma mesma cultura, tendemos a pensar que nossas conversações estão ocorrendo naturalmente de modo harmonioso, entretanto, para os autores, estamos o tempo todo engajados em um trabalho interpretativo, levando em consideração o conhecimento do contexto, a fim de construirmos esta conversação harmoniosa.

O pesquisador deve também explicitar como se deu o processo de escolha dos participantes, explorando as conseqüências desta escolha, garantindo com isto a visibilidade do processo de construção do corpus da pesquisa (SPINK, 2004). Para a seleção dos participantes, é utilizado um conceito de generalização diferente do das pesquisas influenciadas pelo paradigma positivista. O conceito de generalização utilizado aqui é o de "generalização analítica", que significa que caberá ao leitor verificar e validar os conhecimentos produzidos pelo estudo em seu contexto clínico e profissional, testando assim sua aplicabilidade (LYONS; COYLE, 2007; TURATO, 2005). Spink (2004) sugere que a generalização ocorra utilizando-se o que foi produzido no estudo como exemplos de possibilidades existentes nos processos de produção de sentidos

De acordo com a perspectiva adotada aqui, não é possível que o pesquisador esteja neutro na pesquisa, sendo este influenciado por suas leituras prévias, diálogos, experiências profissionais e de vida. Estas influências estarão presentes na definição do objeto a ser estudado, na escolha dos interlocutores com quem compartilhará suas idéias durante o processo, na coleta de dados, na análise e na redação do trabalho final (TAYLOR, 2008; HOSKING; MCNAMEE, 2009). Com todas estas influências, como garantir que o estudo mantenha sua cientificidade? A proposta de diversos autores para esta questão é a de que o pesquisador assuma que não é neutro e explore como suas experiências influenciaram na forma como o fenômeno foi definido, dando visibilidade a estas informações (COYLE; LYONS, 2007; WILLIG, 2005; SPINK, 2004). Willig (2005) propõe o conceito da reflexividade, chamando a atenção para o cuidado que o pesquisador deve ter em conhecer e analisar sua influência no processo de construção do objeto de pesquisa e dos significados produzidos nesta. A autora diferencia a reflexividade pessoal da reflexividade epistemológica, conceituando-as como a seguir. A reflexividade pessoal diz respeito ao pesquisador, a como seus valores, experiências, interesses, crenças, posições e objetivos vão moldando sua pesquisa. A reflexividade epistemológica busca responder questões referentes ao modo como o objetivo da pesquisa delimitou a construção do objeto estudado, assim como as delimitações feitas pelo desenho do estudo, pelas questões da entrevista e pela técnica de análise. A reflexividade nos ajuda a refletir sobre como este objeto poderia ser construído caso fossem escolhidos outros caminhos.

A ética na pesquisa construcionista social vai além de aprovações em comitês de ética e leitura de termos de consentimento. Tomando-se a pesquisa como uma prática social, o pesquisador deve ter em mente que seus resultados estarão produzindo algo na 
sociedade e deve, portanto refletir sobre as possíveis conseqüências destes resultados (SPINK, 2004; HOSKING; MCNAMEE, 2009). O pesquisador também deve estar alerta à sua influência e à da pesquisa na vida dos colaboradores, desde o convite feito a eles para a participação, até o encontro para a coleta de dados. Para o construcionismo social todas as pesquisas provocam algo nos participantes. Desta forma, o pesquisador deve estar atento a todos os passos da coleta de dados, para que este "algo" seja generativo para quem colabora com o estudo.

A "utilidade" do que está sendo produzido e o fato de "ser generativa" são critérios importantes na pesquisa construcionista, auxiliando o pesquisador na tomada de decisões (BURR, 2003). Desta forma, é possível selecionar um colaborador ou uma entrevista por considerá-la mais generativa que a outra. Ser útil ou ser generativa diz respeito ao potencial de abrir novas possibilidades de diálogo. As pesquisas construcionistas trazem a preocupação de explorar outras formas de descrever o fenômeno, de propor novas possibilidades de construir e pensar aquele objeto, auxiliando na transformação social (HOSKING; MCNAMEE, 2009). O pesquisador construcionista deve estar engajado na questão: de que outro modo posso ver este objeto, diferente do que já foi produzido?

Para concluir, frente aos desafios encontrados no fazer ciência, o rigor da pesquisa construcionista está definido como "a possibilidade de explicitar os passos da análise e da interpretação de modo a propiciar o diálogo" (SPINK, 2004).

\section{Local do estudo}

As colaboradoras deste estudo foram usuárias da um serviço ambulatorial para o tratamento de farmacodependências de um hospital. Este serviço se caracteriza por oferecer assistência psiquiátrica em nível ambulatorial, disponível para a rede pública através do SUS, obedecendo a uma orientação atual voltada para os objetivos de hierarquização da assistência, em que o hospital está identificado com o nível de atenção terciária à saúde.

$\mathrm{Na}$ época do estudo, esta unidade contava com uma equipe de residentes em psiquiatria e médico psiquiatra. As abordagens terapêuticas oferecidas eram: psicofarmacoterapia, grupo de psicoeducação para alcoolistas e grupo de familiares.

Foi solicitada a concordância do responsável pela unidade para a realização das entrevistas e este foi favorável à realização do estudo neste serviço. 


\section{Colaboradoras do estudo}

A seleção das colaboradoras do estudo foi feita de modo intencional, seguindo o proposto por Turato (2005) para pesquisas qualitativas ("busca proposital de indivíduos que vivenciam o problema em foco e/ou tem conhecimento sobre ele"). No mês de março de 2006 , solicitei ao hospital uma lista com os números dos prontuários de mulheres que fizeram tratamento na Unidade de Farmacodependências (UF) durante o período de 2000 a 2005. Foram identificados 110 prontuários.

No período de junho a agosto de 2007, realizei leituras minuciosas de 71 prontuários, anotando em meu diário de campo informações relevantes sobre todas as consultas realizadas por estas mulheres na UF. De posse destas anotações, utilizei os critérios de exclusão, justificados a seguir:

- ter falecido - por ser uma pesquisa na qual precisaria entrevistar a participante.

- não ter registro de realização de tratamento na UF - a falta de registro no prontuário de passagem pelo serviço parece ter ocorrido devido a erro do funcionário ao registrar a unidade em que a mulher seria atendida, já que foi encontrado registro de tratamento no serviço em questão, só que em outras unidades, não havendo registro de uso indevido de álcool.

- freqüentar o serviço como participantes de grupo de familiares de alcoolistas algumas mulheres que são esposas ou mães de usuários do serviço freqüentam a UF participando do grupo de familiares, não fazendo tratamento para uso de álcool.

- realizar tratamento para outras drogas que não o álcool - o foco deste estudo era sobre o consumo de álcool, portanto foram excluídas mulheres em tratamento para outras substâncias, como tabagismo ou crack.

- não morar em Ribeirão Preto - SP - como seriam realizadas entrevistas face-aface, optou-se por selecionar apenas moradoras de Ribeirão Preto, facilitando assim a locomoção para os encontros.

- ter prejuízos severos devido ao consumo de álcool - optou-se por excluir mulheres onde se encontrou relato de transtornos psicóticos e demência alcoólica que poderia levar a dificuldades de comunicação. A opção do estudo era por mulheres que vivenciaram a problemática com álcool mas no entanto tinham uma vida razoavelmente preservada, conseguindo manter atividades domésticas, familiares, de auto-cuidado, dentre outras. A importância dada aos registros que indicavam que a paciente mantinha uma boa comunicação se deu pelo fato da coleta de dados utilizar como instrumento a entrevista.

- ter freqüentado o serviço em apenas uma consulta - um dos objetivos iniciais deste estudo foi compreender como mulheres que fizeram tratamento por álcool 
construíram este consumo como problema. A usuária que freqüentou apenas uma consulta e deixou o tratamento pode tê-lo feito por não ter construído o consumo como problema, desta forma, optou-se por excluí-las.

Com a utilização dos critérios de exclusão foram selecionadas 07 mulheres. Destas, não consegui fazer contato com 02, por mudança no número do telefone. Fiz contato com 05 mulheres, entretanto, uma concordou em participar, mas não compareceu na entrevista. Desta forma, realizei ao todo 04 entrevistas, com total de 07 horas e 45 minutos de duração. A primeira delas não foi selecionada para compor o corpus deste estudo, já que diferentemente das outras, não pedi que me narrasse a história de sua vida e apenas segui o roteiro que havia preparado, como uma entrevista estruturada. Deste modo, o texto final produzido por nossa conversa foi muito diferente do produzido nas entrevistas seguintes, quando adicionei o outro instrumento. A quarta entrevista também não foi selecionada já que a participante não tinha diagnóstico de dependência de álcool e sim relato de consumo de risco. Nesta entrevista, sua narrativa focou-se no consumo de álcool feito por seu esposo, e embora tivesse conteúdos generativos, estes desviavam dos objetivos deste estudo. Com isto, 02 entrevistas foram selecionadas para compor o corpus deste trabalho.

É importante destacar que os critérios utilizados para a seleção das colaboradoras influenciou no modo como este texto foi construído. Miriam e Ana são mulheres que tiveram seu consumo de bebidas alcoólicas construído como um problema, entretanto, mesmo sendo oprimidas por estas construções, desempenham diversas outras atividades e conseguem se inserir socialmente sem serem diretamente posicionadas como dependentes de bebidas. As duas colaboradoras também têm em comum o fato de terem passado por tratamento no serviço selecionado e não terem parado de beber. Caso outras mulheres fossem selecionadas, provavelmente a história contada neste estudo seria outra. Isto não invalida nossos resultados, já que estes não pretendem ser generalizados para todas as mulheres que passam por tratamento por consumo problemático de álcool. Compreendemos que as discussões possibilitadas pelas conversas com Miriam e Ana podem ser generativas e nos ajudar a refletir sobre este campo de estudo. 
Quadro 01. Descrição de seleção das colaboradoras na pesquisa. Ribeirão Preto, 2009.

\begin{tabular}{|l|c|}
\hline & Total \\
\hline Total de registros levantados pelo hospital (2000-2005) & 110 \\
\hline Número de prontuários consultados & 71 \\
\hline Excluídas por razão de óbito & 09 \\
\hline Excluídas por não terem registro no prontuário de passagem pelo UF & 33 \\
\hline $\begin{array}{l}\text { Excluídas por freqüentarem o serviço como participantes de grupo de } \\
\text { familiares de alcoolistas }\end{array}$ & 05 \\
\hline $\begin{array}{l}\text { Excluídas por realizarem tratamento para outras drogas que não o } \\
\text { álcool }\end{array}$ & 06 \\
\hline Excluídas por não morarem em Ribeirão Preto - SP & 06 \\
\hline Excluídas por terem prejuízos severos devido ao consumo de álcool & 02 \\
\hline Excluídas por terem freqüentado o serviço em apenas uma consulta & 03 \\
\hline $\begin{array}{l}\text { Selecionadas, portanto não entrevistadas, por não ter conseguido } \\
\text { fazer contato no período destinado para a coleta de dados }\end{array}$ & 02 \\
\hline $\begin{array}{l}\text { Selecionada, portanto não entrevistada, por ter sido convidada a } \\
\text { participar, porém não ter comparecido }\end{array}$ & 01 \\
\hline Entrevistadas & 04 \\
\hline Selecionadas para compor o corpus do estudo & 02 \\
\hline
\end{tabular}

A fim de proteger a identificação das colaboradoras do estudo, o nome destas foi trocado. Segue abaixo uma breve descrição de dados de identificação destas colaboradoras:

- Miriam: negra, 54 anos, solteira, sem filhos, mora com pai, Ensino Médio Completo, funcionária pública - área: serviços gerais, diagnóstico de Síndrome de Dependência ao Álcool, queixa inicial: "não consigo parar de beber, não sou eu", usuária do UF no período da entrevista, em tratamento neste serviço há 04 anos e 09 meses. (entrevista com 2h de duração)

- Ana: branca, 63 anos, divorciada, 02 filhos, mora com uma sobrinha, aposentada área: telefonia, Ensino Fundamental Incompleto, diagnóstico de Síndrome de Dependência ao Álcool, queixa inicial "quero parar de beber devido à insistência de minha filha", desistiu do tratamento, ficou em tratamento no UF por 08 meses. (entrevista com 3h de duração) 


\section{Instrumentos e procedimentos}

Os instrumentos utilizados para a coleta de informações que compuseram o corpus deste trabalho foram: entrevista de história de vida e caderno de campo.

A entrevista de história de vida é um recurso já muito utilizado na literatura, inclusive com usuários de drogas (TOLVANEN; JYLHÄ, 2005; LIEBLICH; TUVALMASHIACH; ZILBER, 2004; MACRAE, 2004; SILVA, 2003), sendo considerada como um instrumento importante para o trabalho com informações que passariam desapercebidas em metodologias mais generalizantes (MACRAE, 2004). Na tradição das ciências sociais, a entrevista de história de vida é uma estratégia de investigação que pressupõe a existência de uma verdade, ou seja, de uma vida que será relatada na entrevista. Dentro da perspectiva do discurso construcionista social, a entrevista de história de vida é compreendida como uma narrativa, que se caracteriza por focar nos significados que o indivíduo dá às suas experiências, significados estes negociados na relação com o entrevistador, sendo, portanto, relatos únicos. Nessa perspectiva, a produção de sentidos leva em conta as dimensões básicas do discurso construcionista: estará permeada pelos quatro tempos (longo, vivido, curto e prospectivo), pela noção de linguagem como construtora das experiências relatadas e de pessoa que se posiciona e é posicionada na relação com seus interlocutores. Desta forma, neste estudo compreendemos que as narrativas de história de vida foram construídas no tempo curto (momento da entrevista) pela entrevistadora e entrevistada; trouxeram vozes presentificadas durante o tempo vivido, ou seja, de diversos interlocutores que cruzaram em diferentes momentos os caminhos da entrevistadora e da entrevistada; trouxeram discursos e repertórios utilizados social e culturalmente no tempo longo; assim como perspectivas futuras do tempo prospectivo (SPINK, 2004; ROSSETI-FERREIRA; AMORIM; SILVA, 2004).

Neste encontro de tempos, vozes e discursos, o indivíduo produz o sentido de suas experiências, e na presença e com a participação do ouvinte, constrói-as e reconstrói-as. (HERMANS, 2007). Sendo assim, ouvinte (listenner) e falante (speaker) se engajam na criação de um relato, construindo a história final. Desta forma, é através das narrativas que as pessoas vivem e estruturam suas vidas e seus efeitos podem ampliar ou restringir suas possibilidades existenciais (GRANDESSO, 2000).

Lieblich, Tuval-Mashiach e Zilber (1998) têm um extenso trabalho com entrevistas narrativas e afirmam que as pessoas são contadoras de história. As histórias dão coerência, continuidade e sentido para as experiências pessoais e têm um papel central na comunicação com outros. Para autores construcionistas, as narrativas oferecem aos pesquisadores um modo de conhecer como as pessoas constroem sua identidade (GERGEN, 2006). Ao se contar histórias, as pessoas criam, recriam, revêem, contam e recontam a vida. Lieblich, Tuval-Mashiach e Zilber argumentam que as histórias são 
construídas ao redor de eventos ocorridos na vida, entretanto as pessoas selecionam, dão ênfase, adicionam e interpretam estes eventos de diferentes maneiras ao construir suas narrativas.

Desta forma, neste estudo compreendemos que a história de vida produzida em uma entrevista é uma das possíveis versões de si e de sua história, construída no tempo curto (durante a entrevista), levando-se em consideração diálogos presentes e presentificados. Ao estudar e analisar histórias de vida, o pesquisador pode conhecer como o indivíduo produz o sentido de si, o sentido de sua história de vida, de seu mundo social e cultural.

Para a realização das entrevistas de história de vida, foram explicados os objetivos da pesquisa e, com a concordância da colaboradora em participar, era pedido que ela contasse a história de sua vida (SILVA, 2003). Trabalhei com a hipótese de que ao explicar o objeto de estudo da pesquisa, eu já estaria posicionando a colaboradora frente a este tema (uso de álcool), sendo este então tratado com certa ênfase durante o relato. Além disto, a fim de atingir os objetivos propostos no estudo, preparei um roteiro com alguns temas que eram trazidos para a conversa, quando percebia que havia espaço para isto. Este recurso se aproxima de outro descrito na literatura como "história de vida temática", utilizado em outros estudos na área de saúde mental (PEGORARO; CALDANA, 2008; PEGORARO; CALDANA, 2006; OLIVEIRA, CALDANA; 2004).

É importante destacar que o roteiro apresentado aqui não foi seguido como um questionário. Ele foi preparado antes das entrevistas e auxiliou a refletir sobre temas importantes de serem conversados e sobre formas de fazer perguntas durante a conversa, sendo coerente com os objetivos deste estudo e com o discurso construcionista social, que entende que o momento da entrevista não é apenas momento para colher dados, mas para construir realidades. Deste modo, pareceu-me importante refletir sobre questões que poderiam ser utilizadas para trazer novas vozes para a conversa e expandir as possibilidades de descrição. Este roteiro não foi levado para as entrevistas, mas inspirou posições, perguntas e intervenções feitas durante esta, favorecendo maior aprofundamento no tema deste estudo e abrindo novos e importantes direcionamentos para a conversa.

O Quadro 02 apresenta este roteiro, que foi composto por 07 temas. Abaixo de cada um deles, há algumas questões que ilustram como estes temas foram abordados.

O roteiro foi construído levando-se em consideração o discurso construcionista social que compreende pesquisa como prática social. Ao fazermos uma entrevista estamos, dentre outras coisas, colaborando para construir a realidade da entrevistada, inserindo nossa voz ao seu conjunto de vozes que a ajudará a compor sua história. Desta forma, durante todas as entrevistas, houve a preocupação de não posicionar a colaboradora como dependente, alcoolista ou usuária abusiva de bebidas. Este cuidado 
se deu por entender que estas descrições poderiam cristalizar as versões identitárias e posicionar as colaboradoras como pessoas doentes ou frágeis, o que não era desejado.

Algumas questões foram feitas de modo a convidar as colaboradoras a olharem para o álcool como algo externo a elas, quase personificado, sendo tratado como algo com o que elas se relacionam. Este tipo de abordagem foi proposta por White e Epston (1990) e é chamada de "externalização do problema". A externalização é uma abordagem terapêutica que convida as pessoas a "coisificarem" e, quando necessário, personalizarem o problema que as aflige. Os autores afirmam que geralmente as pessoas consideram os problemas inerentes a elas, relacionando-se com eles de modo rígido, tendo uma visão saturada por eles (Tomm, 1994). Ao tratar o problema como uma entidade separada, a pessoa pode permitir-se olhá-lo de outras maneiras, articulando novas possibilidades para resolvê-lo. Com isto, os relatos que geralmente dominam, podem ser deixados um pouco de lado, abrindo espaço para que a pessoa identifique aspectos antes ignorados, chamados por White e Epston como "acontecimentos extraordinários". Os autores sugerem que o entrevistador e/ou terapeuta, ao deparar-se com algum acontecimento extraordinário, estimule o entrevistado e/ou paciente a desenvolver novos significados em relação a ele e com isto, construir uma história alternativa.

Partindo do princípio de que o problema não estava dentro das mulheres, além de externalizar o tema de uso de álcool, as questões ilustradas no roteiro procuraram investigar o enquadramento discursivo do problema (MACHADO; MATOS, 2007), levando-se em consideração seus aspectos contextuais e relacionais. Ao entender que os enunciados feitos pelas colaboradoras eram compostos por vozes (de médicos com os quais já conversaram, de familiares com quem convivem, de vizinhos, dentre outros) e não a representação de um pensamento ou sentimento interno e individual, a entrevistadora preocupou-se em conhecer melhor quais eram estas vozes e como estas participavam para a composição dos enunciados e dos significados dados às experiências. Esta preocupação refletiu-se nas questões que investigavam o que elas imaginavam que médicos, familiares e vizinhos pensavam sobre o relacionamento que tinham com bebidas alcoólicas.

Considerando-se que as descrições sobre o uso de álcool poderiam variar não apenas de acordo com a quantidade e a freqüência do uso, mas com o contexto de vida e de consumo, foram feitas algumas questões em que o convite era para que elas refletissem sobre os diferentes momentos no relacionamento com o álcool. Este convite estendeu-se também para pensar a mudança, mais especificamente, o que acontecia em suas vidas nos momentos em que desejavam mudar e como se descreviam nestes momentos. Para White e Epston (1990), questões deste tipo ajudam o entrevistando a refletir sobre como suas relações influenciam "a vida" do problema. 
Outra preocupação ocorrida durante as entrevistas foi a de posicionar as colaboradoras na posição de "experts". Este é um cuidado realçado pelo discurso construcionista social que vem de encontro com as posições atuais do SUS para a relação profissional e usuário do serviço (AYRES, 2004; MCNAMEE, 2004). Ao final das entrevistas, era pedido às colaboradoras que imaginassem que tivessem que dar orientações para profissionais que queriam montar um serviço para mulheres usuárias de álcool. Pedia então para que elas descrevessem estas sugestões. Além disto, foi pedido que dessem sugestões para as mulheres que buscassem ajuda para mudar seu padrão de consumo de álcool.

Durante toda a entrevista, foi também dada atenção aos aspectos dialógicos, valorizando o engajamento do pesquisador. De acordo com Frank (2005), a pesquisa dialógica se preocupa em ouvir as histórias dos participantes de modo engajado, levando-se em consideração o modo como questões específicas podem instigar autoreflexões, propiciando não apenas um relato da vida, mas uma mudança na vida. Respeitando-se os cuidados éticos, ao final da entrevista era perguntado às colaboradoras sobre o que a entrevista havia despertado nelas e como estavam indo embora depois da conversa.

Em relação ao contato com as colaboradoras, este foi feito inicialmente pelo telefone. Nesta ocasião, apresentei-me como psicóloga, pesquisadora de um projeto com mulheres que fizeram tratamento ambulatorial psiquiátrico no serviço em questão (destaca-se que este projeto de doutorado está inserido dentro de um projeto maior coordenado pela Profa. Dra. Ana Maria Pimenta Carvalho da EERP - USP - "Mulheres, mães, portadoras de transtorno mental: características sócio-demográficas e vivenciais" onde mulheres em tratamento por diferentes diagnósticos psiquiátricos foram selecionadas e convidadas a colaborar em uma entrevista. Desta forma, optei por não mencionar o tratamento por problemas com álcool e sim dizer sobre o tratamento no serviço ambulatorial psiquiátrico). Expliquei que eu e outra colega havíamos pedido para o serviço uma lista com o número dos prontuários de todas as mulheres que fizeram tratamento psiquiátrico e que estávamos fazendo contato com algumas destas mulheres para conversarmos um pouco mais sobre a vida delas, sobre o tratamento em que participaram e sobre o problema que as levou a procurar este. Assim, convidei-as a participar, deixando como opção a realização da entrevista no domicílio destas ou no meu local de trabalho. As duas colaboradoras optaram por ir até meu local de trabalho. Deste modo, as entrevistas foram conduzidas em uma sala fechada, garantindo a privacidade necessária para a conversa. Foi pedido autorização para realizar a áudiogravação da conversa, assim como fizemos a leitura em conjunto do Termo de Consentimento Livre e Esclarecido, iniciando a conversa somente após a concordância das colaboradoras. 
Quadro 02. Exemplos de temas e questões abordadas na entrevista. Ribeirão Preto, 2009.

1. Histórias diferentes e possíveis sobre o álcool em sua vida:

Queria que você me contasse histórias que mostrem os aspectos bons do álcool em sua vida.

Conte-me histórias que você imagina que as pessoas próximas contariam sobre seu relacionamento com o álcool.

Imagine dois médicos conversando sobre o seu relacionamento com bebidas alcoólicas. O que você imagina que eles estariam falando?

Você conversa com alguém sobre seu relacionamento com bebidas alcoólicas? Com quais pessoas e o que?

2. Momentos diferentes no seu relacionamento com bebidas alcoólicas:

Agora eu queria que você pensasse nos momentos de sua vida em que bebeu mais. O que estava acontecendo na sua vida naqueles momentos? O que você imagina que pode ter influenciado para que você bebesse desta maneira?

Agora vamos pensar nos momentos em que você bebeu pouco ou não bebeu. O que estava acontecendo na sua vida naqueles momentos? O que você imagina que pode ter influenciado para que você bebesse desta maneira?

Já aconteceu de você propor que queria mudar o modo como se relacionava com bebidas alcoólicas? O que estava acontecendo na sua vida neste momento?

Você conseguiu cumprir com esta proposta? O que ajudou a cumprir e o que não ajudou?

O que você considera como um sucesso no seu relacionamento com bebidas alcoólicas? O que poderia te atrapalhar alcançar este sucesso? O que poderia te ajudar a alcançar este sucesso?

3. Pessoas próximas a você:

Como é para você ouvir o que pessoas próximas falam sobre seu relacionamento com bebidas alcoólicas?

Se você tivesse a oportunidade de conversar com estas pessoas sobre este relacionamento com BA, o que você diria?

\section{Momentos difíceis com o álcool}

Agora eu queria que você contasse algum momento mais desagradável de seu relacionamento com BA. O que tornou este momento tão desagradável?

O que você faz para não ter mais momentos como este?

5. Percepções sobre o consumo de bebidas alcoólicas

Porque você imagina que as pessoas bebem?

Quando você imagina que uma pessoa tem problemas com bebidas alcoólicas?

6. Opiniões da especialista

Com a sua experiência, se você tivesse que dar um conselho para uma mulher que está consumindo bebidas alcoólicas e acha que tem problemas, que conselho você daria?

Se fossemos montar um serviço voltado para mulheres que gostariam de mudar o modo como bebem e convidássemos você para nos dar uma supervisão ou uma orientação sobre como montar este serviço, que sugestões você daria?

7. Você acha que esta conversa teve alguma utilidade para você? 
Para composição do corpus, foram utilizadas também as notas de meu caderno de campo. Neste caderno registrei informações sobre: prontuário das colaboradoras (anotações do médico sobre as consultas realizadas, diagnóstico e conduta); conversas informais com profissionais que tiveram contato com algumas delas; processo de construção dos instrumentos de coleta de dados, de convite, realização de entrevistas e da análise.

As leituras dos prontuários foram realizadas entre junho a agosto de 2007 e as entrevistas entre setembro e novembro de 2007. As transcrições foram feitas logo após o término do período de entrevistas.

\section{Considerações éticas}

Este projeto foi encaminhado para análise e obteve aprovação do Comitê de Ética da instituição onde foi realizada a pesquisa (10/01/2007, processo no. 13420/2006).

Todas as entrevistas foram realizadas respeitando-se os critérios éticos da resolução no 196 de 10 de outubro de 1996. Os objetivos da pesquisa eram inicialmente explicados às colaboradoras, seguindo-se pelo pedido de autorização para a gravação destas. O local das entrevistas foi escolhido por elas, sendo privativo. Foi garantida a confidencialidade das informações, havendo o compromisso de proteger a imagem e evitar a estigmatização. As colaboradoras tiveram autonomia para decidir sobre a participação, sendo que a entrevista só ocorreu após elas terem assinado o Termo de Consentimento Livre e Esclarecido. Além disto, elas levaram uma cópia do termo de consentimento, onde constava meu telefone e e-mail para, caso sentissem a necessidade, pudessem entrar em contato comigo.

\section{Análise do corpus}

A análise do corpus foi dividida em dois momentos: 1) Imersão no caderno de campo; 2) Imersão nas entrevistas.

\subsection{Imersão no caderno de campo}

Motivada pela generatividade das anotações do caderno de campo, dediquei o início da análise à discussão e reflexão sobre o fazer pesquisa no campo de álcool e outras drogas, dando visibilidade às decisões do estudo.

A escolha da inserção deste texto no corpo de análise se deu motivada pela discussão de Coyle (2007) sobre a reflexividade pessoal do pesquisador. Para ele, há 
diferentes formas para que o pesquisador dê visibilidade às suas posições, sendo que alguns optam por fazê-lo em um capítulo introdutório, ou então como um anexo. Entretanto, ele aponta que quando estes dados são tratados desta maneira, podem passar a impressão de que esta discussão não é tão importante ou de que "contaminará" o estudo. Neste estudo, entende-se que os resultados são construções narrativas do pesquisador em interação com suas múltiplas vozes (colaboradoras, literatura, pesquisadores, amigos, ...) e com os diferentes discursos presentes na sociedade. Dentre as diversas construções possíveis, o pesquisador fez opções no decorrer do estudo, e entende-se aqui que estas opções podem ser utilizadas para propiciar diálogos com os leitores.

\subsubsection{Análise do caderno de campo}

Realizei a leitura dos registros digitais e manuais feitos durante o período da entrevista, destacando os momentos que poderiam ser utilizados para este primeiro momento da análise. Relatei estes momentos, destacando discursos, vozes e posicionamentos na composição do texto.

\subsection{Imersão nas entrevistas}

Para a análise das entrevistas, fui orientada pela proposta de Etorre $(1997,2007)$ de produção de material de pesquisa que não fosse sobre mulheres, mas para mulheres. Adotei o que a autora chama de "posição sensível à mulher", que leva em consideração que a mulher não é apenas prejudicada pelo álcool, mas também pela falta de entendimento a respeito do seu consumo. Com isto, minha proposta é a de construir descrições que não estigmatizem ou enfraqueçam as mulheres, mas que convidem o leitor ao diálogo, com o olhar para o empoderamento destas.

Dentro da perspectiva deste estudo, as histórias de vida descritas não representam as histórias verdadeiras, mas são construções realizadas pelas participantes no tempo presente, ou seja, no diálogo com a entrevistadora. Neste diálogo participam também as vozes presentificadas pela colaboradora e pela entrevistadora, pertencentes ao tempo vivido, assim como os discursos sociais, partes do tempo longo.

Estas descrições tornam-se possíveis através da linguagem, na construção das histórias e do jogo de posicionamentos presentes no momento da entrevista. Foi considerado, portanto, que ao narrarem suas histórias de vida, as colaboradoras estavam dando significado às suas vivências, além de estarem selecionando quais vivências ganhariam significado. Desta forma, o relato de história de vida foi entendido como modelador de suas vidas (WHITE; EPSTON, 1993). 
Para realizar a análise, inspirei-me na análise do discurso, segundo proposta por Potter e Wetherell (1987), Willig (2001) e Burr (2003).

\subsubsection{Análise do discurso}

Discurso é um conceito polissêmico, assim como a análise do discurso traz diferentes sentidos, tradições e práticas. Os discursos são um conjunto de significados, metáforas, representações, imagens, histórias e afirmações que produzem uma versão particular de um objeto (POTTER; WETHERELL, 1987). Neste estudo, compreendemos discursos concordando com Foucault, de que estes são práticas que constroem os objetos sobre os quais falam (WILLIG, 2001). Os discursos são práticas sociais, e a função do analista de discurso seria revelar os efeitos destes e o modo como estes efeitos constroem o mundo, a fim de despertar uma atitude crítica sobre o tema estudado (IÑIGUEZ, 2004).

De acordo com esta perspectiva, os discursos legitimam estruturas sociais e institucionais, ao mesmo tempo em que estas estruturas suportam e validam os discursos. Neste estudo, a análise do discurso é compreendida junto à noção de linguagem como construtora da realidade. Uma pesquisa que utiliza da análise do discurso compreende que também é influenciada por discursos compartilhados pelo seu contexto. Frente a isto, a literatura sugere que o analista mantenha um diálogo com os leitores, dando visibilidade ao modo como construiu seu texto e convidando os leitores para realizarem outras construções. Para Iñiguez (2004, p.145) "a análise do discurso se converte em um exercício mais de negociação do que de exposição, no sentido de estar sempre aberta ao debate e à discussão das interpretações realizadas". Ao revelar e identificar práticas discursivas, o objetivo da análise do discurso seria abrir caminhos para outras possibilidades de entendimento, levando à transformação.

A análise do discurso vem crescendo dentro das ciências humanas e sociais, ganhando espaço cada vez maior na psicologia social. Dentro desta disciplina, a análise do discurso vem sendo considerada como um convite à transformação, sendo uma alternativa a impasses ocorridos neste campo, que vem recebendo críticas por se aproximar do controle social, ao estabelecer normas de comportamento e de saúde, apoiando-se em um discurso científico construído como saber inquestionável (NOGUEIRA, 2008).

A análise do discurso realizada neste trabalho aproxima-se do proposto por Willig (2001), nomeada como análise de discurso foucaultiana. Compreendendo que diferentes construções trazem diferentes conseqüências, esta análise busca conhecer os discursos que estão sendo utilizados para construir determinado fenômeno e os efeitos destes para as práticas e para a construção de versões identitárias. Não há discursos verdadeiros ou 
falsos, mas busca-se compreender como que, historicamente, se produzem efeitos de verdade no interior dos discursos (FOUCAULT, 2004).

Deste modo, neste estudo, foram identificados discursos utilizados em nossa conversa. A partir da identificação destes discursos, foram analisados os possíveis efeitos destes, tanto para a construção de versões identitárias, como para a abertura de possibilidades de ação no mundo. Compreende-se que os modos como as pessoas se apresentam e como agem no mundo estão relacionados com os discursos utilizados. 0 discurso da dependência como doença pode ser usado como um exemplo aqui. Ele nos disponibiliza o posicionamento de 'paciente' e não o de 'sem-vergonha', posicionamento este disponibilizado pelo discurso da dependência como problema moral. Com o discurso da dependência como doença, uma das possibilidades de ação disponibilizadas é a procura por tratamento, algo que não ocorreria com o uso do discurso da dependência como problema moral.

De acordo com esta perspectiva de análise, os discursos auxiliam a construir modos de ser no mundo. Lembramos que o discurso construcionista social não considera que temos uma personalidade central, nuclear e coerente. Desafia-nos a pensar em como ficariam as características que identificamos nas pessoas, como timidez, avareza, generosidade e inveja caso estas pessoas não estivessem em uma relação. Autores construcionistas propõem que estas características não são intrínsecas as pessoas, mas são construídas nos relacionamentos. Como alternativa para esta questão, os pesquisadores Langenhove e Harré (1999) propuseram a "teoria do posicionamento". Ela foi descrita como sendo dinâmica, diferente do conceito estático de "papéis". De acordo com esta teoria, as pessoas usam posições fluidas para lidarem com as situações sociais. As posições podem aparecer naturalmente em um contexto conversacional ou serem dirigidas por discursos dominantes, que pré-estabelecem algum tipo de relação. Uma posição assumida inicialmente pode ser mudada durante a relação/diálogo. Quando duas pessoas estão em relação, elas posicionam o outro ao mesmo tempo em que se posicionam e são posicionadas. Desta forma, ao se posicionarem, estão posicionando o outro e ao posicionarem o outro, estão se posicionando. É um movimento dinâmico e na maioria das vezes não intencional.

Nestes jogos de posicionamentos, criam-se e restringem-se possibilidades, ampliando ou não as possibilidades de versões identitárias (OLIVEIRA; GUANAES; COSTA, 2004). Quando a pessoa se engaja em uma relação, ela traz, de suas histórias prévias, posições já assumidas, convidando o interlocutor a sustentar estas posições. Caso isto ocorra, colaborará para o sentimento de continuidade do ser.

O conceito de pessoa utilizado neste estudo parte então da noção de relação, ou seja, a pessoa está a todo o momento negociando com suas vozes, produzindo seus sentidos na interação com outros e se posicionando de acordo com seus interlocutores. 
Considera também que estes posicionamentos dependerão dos discursos utilizados nos diálogos, que disponibilizam e restringem modos de ser.

Como os outros são múltiplos, múltiplas são as vozes que compõem seu mundo social e múltiplas são as posições que ocupa nos diferentes contextos, frente aos diferentes interlocutores e com o uso de diferentes discursos. Podemos então dizer que a pessoa é múltipla e devido à construção cultural de unicidade e permanência do self, temos este sentimento de identidade, de ser único (ROSSETI-FERREIRA; AMORIM; SILVA, 2004).

\subsubsection{Análise das entrevistas}

Realizei pessoalmente a transcrição literal de todas as entrevistas, e a fim de diferenciar a minha fala e a da colaboradora, ao início das falas coloquei nossas iniciais (Clarissa - C; Miriam - M; Ana - A). O registro de pensamentos e sentimentos que tive durante a entrevista, assim como o tom emocional da colaboradora, foi feito entre parênteses (ex. chorosa). Os momentos em que eu ou a colaboradora dávamos uma pausa após dizer algo, utilizei o recurso dos três pontos (...). Ao final das transcrições, revi todas as entrevistas a fim de trocar os nomes das colaboradoras, familiares, profissionais e locais, garantindo assim o anonimato. As linhas das entrevistas foram numeradas, do início ao final, e ao final de cada extrato utilizado, foram colocados os números das linhas referentes a este.

Com as entrevistas transcritas, realizei diversas leituras destas, assim como escutei novamente as áudio-gravações, a fim de reviver emoções sentidas durante a conversa, ganhar familiaridade com o conteúdo e destacar momentos marcantes.

Preparei então, tabelas, com duas colunas. Na primeira, coloquei as entrevistas e na segunda, identifiquei discursos, posicionamentos e vozes que ajudavam a construir as narrativas sobre a experiência com o consumo de bebidas alcoólicas e também a construir versões identitárias. Esta análise inicial me proporcionou uma visão geral dos discursos mais utilizados e das versões identitárias que foram construídas durante nossa conversa.

Inspirada pela análise do discurso foucaultiana, proposta por Willig (2001), revi os discursos identificados, atenta ao modo como estes construíam algumas imagens sobre os objetos aos quais se referiam e, com isto, orientavam algumas ações e tornavam disponíveis determinadas posições. Estas posições abriam a possibilidade para algumas ações e fechavam para outras, construindo, em nossa conversa, uma versão de si das colaboradoras.

Utilizando as versões identitárias das colaboradoras que se tornavam disponíveis a partir de minha leitura dos discursos e dos posicionamentos que apareceram durante a 
nossa conversa, escrevi uma história sobre a vida destas, procurando preservar o tom emocional que foi mais marcante para mim durante a conversa. Esta história foi recortada em diversas partes, que no texto aparecem dentro de quadros marcados com bordas finas. Foi a partir dos recortes desta história, que realizei a edição dos trechos que ilustrariam a análise, dando visibilidade aos momentos da conversa que inspiraram minha história. Desta forma, logo após os recortes da história (quadros de bordas finas), são apresentados extratos de nossa conversa.

A fim de dar visibilidade para a análise realizada, após cada extrato da conversa, inseri quadros com bordas grossas, onde descrevo discursos, posicionamentos e vozes presentes no extrato, atenta à análise proposta por Willig (2001), observando como os discursos disponibilizam certos posicionamentos e orientam ações.

É importante ressaltar que a cada extrato ilustrado aqui poderiam ser apresentadas diferentes análises, sendo que cada qual criaria algumas possibilidades de entendimento e, ao mesmo tempo, marginalizariam outras (AVID, 2005).

Os resultados da análise aparecem divididos em dois capítulos: Capítulo 05 apresento os resultados da análise da conversa com Miriam; Capítulo 06 - apresento os resultados da análise da conversa com Ana. Ao final de cada um, destaco convites que podem ser feitos a partir das análises. É um diálogo com a análise realizada e com a literatura, onde pontuo reflexões para o campo de estudo de álcool e outras drogas.

Em seguida, inspirada pelas reflexões levantadas, ao final de cada um destes capítulos, disponibilizo uma carta, endereçada à Miriam e à Ana. Este tem o intuito de oferecer uma outra versão da história destas duas mulheres. Esta carta não foi enviada para as colaboradoras. Foi um exercício de reflexão a fim de chamar a atenção do leitor para a possibilidade de construirmos diversas histórias sobre os eventos. As narrativas apresentadas por Miriam e Ana em nossa conversa, trazem alguns discursos e posicionamentos dominantes, que muitas vezes enfraquecem estas mulheres. Por outro lado, alguns posicionamentos que as fortaleceriam e contribuiriam para a mudança são marginalizados durante nossa conversa. Desta forma, a carta foi usada como ilustração para destacar como, com o uso destes posicionamentos marginalizados, podemos construir outras histórias sobre a vida destas mulheres e, com isto, abrir novas possibilidades de ser e agir no mundo. Esta carta foi inspirada nos trabalhos de David Epston e Michael White (ESPTON; WHITE; MURRAY, 1998) de terapia de re-autoria, em que os autores consideram que a vida das pessoas será direcionada pelas histórias que contam sobre ela e, que assim, criam significados sobre suas experiências. Nesta perspectiva, o terapeuta pode auxiliar o cliente a reescrever sua vida, a construir novos sentidos para suas experiências e assim, abrir-se a novas possibilidades. Os autores afirmam que as pessoas que procuram tratamento geralmente têm algumas narrativas que são dominantes e que dão sentido para suas experiências e vidas. Estas narrativas 
muitas vezes são saturadas pelo problema, impedindo as pessoas, e até o terapeuta, de olharem para além deste problema. Entretanto, para estes autores, o ouvido atento às narrativas ajuda a identificar "acontecimentos extraordinários", ou seja, relatos que podem abrir outras possibilidades para narrar estas experiências, mas que se encontram à margem da narrativa dominante. Esta carta teve como objetivo destacar alguns acontecimentos extraordinários e oferecer alguns posicionamentos diferentes dos utilizados durante nossa conversa. Entretanto, trago aqui a lembrança de Grandesso (2000), de que temos o compromisso ético de não construir nossas práticas como verdades e situá-las dentro de nossas experiências. Desta forma, ressalto que esta é apenas uma outra possibilidade de reconstrução da história de Miriam e de Ana, possibilidade esta circunscrita a meu mundo discursivo. Talvez o leitor considere que minhas cartas mostrem apenas "um lado"/construção da história. Entretanto, considero que "outros lados"/construções já foram apresentados nos quadros de bordas finas e grossas. A proposta aqui é exercitar para a possibilidade de contarmos diferentes histórias sobre a conversa e assim construirmos identidades e realidades. Deste modo, caso o leitor leia apenas os quadros de bordas finas, terá uma versão sobre a história das colaboradoras. Caso opte por ler apenas os extratos da conversa, construirá outra versão sobre a história destas. Caso leia apenas minha carta, terá ainda outra versão. Convido o leitor, participante de outros mundos discursivos, a construir outras histórias e, quando o fizer, a pensar no potencial generativo destas. Para isto, sugiro ter em mente as questões: "Como seria se eu descrevesse assim... que efeito isto teria? Que possibilidades seriam disponibilizadas?". 
Capítulo 4

Histórias sobre o fazer pesquisa nesta área 

Durante a realização deste estudo, tomei algumas decisões que influenciaram no desenho metodológico previsto, sendo que estas mudanças tiveram relação com o tema estudado. Estas experiências foram registradas em meu caderno de campo e ilustram discursos presentes em nossa sociedade. Devido a isto, pareceu-me importante começar a análise do material pelas notas do caderno de campo, com o intuito de expandir o diálogo sobre o fazer pesquisa na área de álcool e outras drogas.

No início do estudo, tinha a idéia de reunir um grupo de mulheres, que foram usuárias de um serviço ambulatorial para tratamento de dependência de álcool, para conversar sobre suas experiências como usuárias de bebidas alcoólicas e como pacientes de uma unidade de farmacodependências. Preparei um roteiro de entrevista grupal e a fim de testar este roteiro, propus montar um grupo com amigas que consomem bebidas alcoólicas.

Procurei algumas amigas que sabiam de meu trabalho na área da prevenção e terapia voltada ao uso problemático de álcool, assim como de meu projeto de doutorado com mulheres e consumo de álcool. Expliquei que havia montado um roteiro de entrevista para fazer com as participantes do estudo e que gostaria de testá-lo. Para isto queria montar um grupo com amigas para conversarmos sobre as experiências destas com bebidas alcoólicas. Conversei com quatro amigas, em momentos distintos, explicando minhas intenções e convidando-as a participar. A reação de todas foi a mesma:

Clá, você acha que eu estou bebendo demais? Você está me chamado de alcoólatra? Você tem percebido algo em mim? Porque eu?

Ao receberem um convite de uma amiga especialista na área de álcool e outras drogas para participarem de uma entrevista piloto em um estudo sobre mulheres e consumo de álcool, minhas amigas sentiram-se observadas, analisadas e julgadas como possíveis usuárias problemáticas de álcool. Sentiram-se posicionadas como 'mulheres com problemas com bebidas alcoólicas'. Foi como se eu apresentasse a elas uma descrição que elas até então não tinham sobre si mesmas e questionaram este posicionamento: "Por que eu?".

Alguns meses após este ocorrido, eu recebi um convite de um pesquisador que mora no mesmo prédio que eu para participar de sua pesquisa. Ele me explicou que o estudo se tratava de felicidade e relacionamento conjugal. A idéia que me passou foi a de que ele deveria ter observado como eu e meu marido somos felizes e temos um bom relacionamento e, portanto, nos convidou para a pesquisa. Recebi o convite como um elogio, aceitei este posicionamento e fiquei satisfeita em poder contribuir. Afinal, queria ser identificada e posicionada como "esposa feliz". 
As questões levantadas por minhas amigas, assim como minha concordância imediata em participar de um estudo sobre felicidade e relacionamento conjugal, me levaram a pensar sobre a (não) neutralidade das pesquisas. A ciência positivista vem tentando reafirmar que seus estudos são inócuos e que ao convidar uma pessoa para participar da pesquisa, não estará influenciando em nada em sua vida. Por estas duas experiências relatadas aqui percebemos que as pessoas percebem-se posicionadas pelos pesquisadores.

Outra reflexão despertada por estas situações refere-se ao modo como meu objeto de estudo vem sendo construído. Como as questões relativas ao uso de álcool são construídas em nossa sociedade? Como nós, profissionais de saúde atuantes na área de álcool e outras drogas, ajudamos na construção desta questão? Estamos atentos aos jogos de posicionamento presentes em nossas relações com os participantes de pesquisas?

Enquanto pesquisadores, quando dialogamos com nossos pares, através da literatura, temos como principal foco de nossos estudos os problemas relacionados ao uso de álcool. Encontramos vasta literatura sobre fatores de risco para o uso de álcool, danos causados pelo consumo, prevenção do consumo e tratamento deste. Quando somos convidados a dialogar com o público em geral, através de palestras ou da mídia, procuramos organizar nossos discursos de modo que sensibilizem os ouvintes a não iniciar o consumo de álcool ou para estarem alertas aos problemas que este pode causar. Representamos 'os que dizem Não!', 'os que dizem 'Cuidado!'.

A literatura destaca modelos teóricos que vêm sendo utilizados para compreender o consumo de bebidas alcoólicas. Consideraremos aqui estes modelos como discursos, que produzem efeitos e criam realidades. O discurso da moral nos diz que as pessoas consomem e perdem o controle sobre o consumo devido à falha no caráter ou por serem fracas. O discurso biomédico utiliza-se da identificação de causas biológicas e hereditárias, que fogem ao controle do indivíduo, construindo este consumo como uma doença. O discurso psicológico apresenta características de temperamento e de personalidade de risco e discute a aprendizagem de comportamentos mal-adaptados, construindo o consumo como resposta mal adaptada do indivíduo a situações do cotidiano. O discurso ecológico utiliza o modelo de doença causada por múltiplos fatores de risco, construindo o consumo problemático como uma doença que pode ser prevenida, a partir da identificação e eliminação dos fatores de risco (PILLON, LUIS; 2004).

Dando suporte à construção do consumo de bebidas alcoólicas como problema de saúde, temos também a literatura epidemiológica que associa o álcool a doenças físicas, acidentes automobilísticos, violência doméstica, baixa produtividade no trabalho, entre outros. Com o uso de discursos que constroem o consumo de bebidas alcoólicas como potencial causador de danos à saúde, a literatura recomenda que os profissionais façam 
busca ativa de casos-problema, identifiquem precocemente o consumo e intervenham sobre ele, orientando o usuário a reduzir ou a deixar de beber, apoiando-se nos danos presentes ou possíveis (BABOR. 2003). Utilizando apenas estes discursos, enquanto profissionais, somos convidados a compreender o consumo de bebidas alcoólicas dentro da perspectiva do problema. Com isto corremos o risco de nos posicionarmos como 'porta-vozes do discurso de consumo de bebidas como problema' ou como 'profissional que batalha contra as drogas'. Será que estes posicionamentos nos aproximam das pessoas que bebem? Será que eles nos ajudam a manter o diálogo aberto?

Além dos discursos da literatura científica sobre a saúde, compartilhamos de discursos construídos por outros atores sociais, como por exemplo, da mídia publicitária. Ela nos diz que o consumo de bebidas alcoólicas ajuda na socialização, auxilia a esquecer as preocupações, a aproveitar mais a vida e a ser mais feliz. Estas são construções que em nossa sociedade estão relacionadas à saúde, ao bem estar e ao prazer. No mundo atual, espera-se que as pessoas se saiam bem socialmente, controlem seus níveis de estresse, cumpram suas responsabilidades ao mesmo tempo em que aproveitam a vida (carpe diem). O discurso da mídia publicitária é o discurso de álcool como prazer e de álcool como saúde, enquanto o discurso dos profissionais é o de álcool como problema e de álcool como doença. Prazer X Problema. Saúde X Doença. Com discursos assim tão dicotômicos, encontramos com freqüência o uso de termos como "combate" e "guerra", importantes repertórios na construção do campo de batalhas onde o tema se insere. Nesta batalha, nós, profissionais de saúde, somos muitas vezes colocados na linha de frente. Enquanto a mídia seduz para as delícias do consumo de bebidas alcoólicas, fazemos nosso trabalho de "formiguinha", na tentativa de mostrar o que vai além dos prazeres (CORRADI-WEBSTER et al, 2008).

O discurso da redução de danos (IHRA, 2009) parece ser uma opção dentro do campo para integrar estes diferentes sentidos sobre o consumo de bebidas alcoólicas. Construído em parceria com o discurso dos direitos humanos e com o discurso da saúde pública, não busca prevenir ou eliminar o consumo de substâncias, mas sim eliminar ou prevenir os danos causados por este consumo. Para isto, convida ao diálogo pessoas que continuarão a consumir substâncias, compreendendo que, pelos mais diversos motivos, algumas têm dificuldades para parar enquanto outras simplesmente não querem parar. As perguntas feitas pelo discurso de redução de danos são: 1. Quais são os principais danos causados pelo consumo desta substância? 2. O que leva a estes danos? 3. O que pode ser feito para preveni-los? É um discurso que considera os sentidos construídos como positivos ao mesmo tempo em que considera os sentidos construídos como negativos. Com o uso deste discurso o profissional permanece posicionado como 'profissional envolvido em trabalhos preventivos' ao mesmo tempo em que mantém abertura para o diálogo com os usuários. Outro convite feito por este discurso é o de 
compreender o consumo dentro de um contexto sócio-ecônomico-cultural. Deste modo, ele também convida a ações que vão para além das orientações individuais, como controle de propagandas, maior controle sobre os pontos de venda (ex. venda para crianças e adolescentes) e regulamentação de algumas práticas (ex. beber e dirigir).

Minhas amigas, ao ouvirem meu convite, entenderam-no como sendo resultado de uma avaliação feita por mim do consumo que faziam de bebidas alcoólicas. Com isto, me posicionaram como 'profissional de saúde da área de álcool' e não como uma 'amiga que precisa de ajuda para o doutorado'. Ao me posicionarem como 'profissional de saúde da área de álcool', virei representante do discurso de álcool como problema, fazendo com que estas se sentissem posicionadas como 'mulheres com problemas com bebidas alcoólicas'. Elas questionaram este posicionamento, perguntando "Porque eu?". Expliquei que o convite não tinha relação com o consumo que faziam, já que eu precisava de mulheres que bebiam, para que as questões pudessem fazer algum sentido, mas que não estava levando em consideração se este consumo era problemático ou não. Disse que o objetivo era testar as questões da entrevista, ter um retorno sobre o potencial generativo destas e sentir-me mais segura para no futuro coordenar o grupo com mulheres que fizeram tratamento pelo consumo de bebidas alcoólicas. Com esta explicação questionei a posição de 'profissional de saúde da área de álcool' e procurei o posicionamento de 'amiga que precisa de ajuda no doutorado'.

Esta situação me levou a refletir sobre os posicionamentos que gostaria de assumir no decorrer da pesquisa. Durante as entrevistas, procurei deixar de lado a posição de 'representante dos que dizem Não!' e com isto, não construir o consumo de álcool como problema. Esta opção ocorreu a fim de não posicionar minhas colaboradoras como 'pessoas que fazem uso abusivo' ou 'dependentes'. Não queria que se sentissem avaliadas por mim e pela situação da entrevista, evitando que saíssem de lá se sentindo culpadas e envergonhadas. Isto não significa que, como entrevistadora, fui uma figura neutra. Pelos anos de trabalho na área estou inundada de vozes e discursos que constroem o consumo de álcool como problema e por mais que tentasse evitar alguns posicionamentos, eles aparecem na entrevista.

A fim de ter maior flexibilidade no uso dos discursos, precisei inserir novas vozes ao meu estudo. Por diversos momentos, desde o preparo do roteiro de entrevista até a análise destas, valorizei o diálogo com pesquisadores e literatura de outras áreas, que por não compartilharem dos mesmos discursos que eu, ajudaram-me a construir outras possibilidades. Dentro do campo de álcool e outras drogas, também me envolvi na busca por outros discursos que não o dominante (biomédico), dialogando com autores da terapia de família, feministas, cientistas sociais e redutores de danos. 
Como profissionais, na relação com nossos pacientes, poderíamos também inserir outras vozes que não a 'dos que dizem Não!', a 'dos que dizem Cuidado!' e com isto ampliar as possibilidades de diálogo e de sucesso terapêutico.

Nos diversos congressos da área em que participo, muito se fala sobre a complexidade do tema "uso de substâncias". Entretanto, apesar de todos concordarem com sua complexidade, o tema é muitas vezes abordado dentro de apenas alguns vértices (ex. problema, doença). Com isto, os ouvintes podem ter a impressão de que estas descrições são "verdades". Discute-se pouco como são criadas estas "verdades". A literatura ainda é tímida em relação aos convites feitos para pensarmos a instituição "ciência" (Langenhove; Harré, 1999). Percebe-se que em todos os campos, esta é controlada por alguns grupos que se alinham aos discursos dominantes (no nosso campo o discurso biomédico), que ajudam a determinar o destino dos recursos financeiros investidos em pesquisas (levando a inúmeros trabalhos que focam no discurso dominante), a determinar a escolha dos palestrantes nos congressos científicos (apesar de termos por todo o Brasil pesquisadores investigando o tema, apenas alguns grupos ganham espaço em congresso de álcool e drogas de grande porte) e assim, a criar "verdades" sobre o tema. Percebe-se então que a ciência também funciona com características mercadológicas. Langenhove e Harré (1999) destacam que a ciência ainda é compreendida como um espaço onde cientistas constroem sobre o que já foi produzido antes, reforçando paradigmas e trazendo algumas novidades a estes. Entretanto, este esforço só é legitimado caso os cientistas consigam tornar público seus estudos, através de publicações e apresentações em eventos. Como já dito anteriormente, a seleção de apresentações em eventos segue alguns critérios que permitem a entrada de alguns enquanto excluem outros. As publicações também. As revistas mais valorizadas na área também têm critérios para suas publicações e seguem determinados paradigmas. Percebe-se a valorização de pesquisas quantitativas, que utilizam o discurso biomédico e que constroem o consumo apenas como problema. Por outro lado, publicações nestas revistas legitimam o pesquisador e seu estudo, auxiliando a construir a compreensão de "verdade". Com isto, Langenhove e Harré (1999) destacam que, na atualidade, pesquisadores precisam também compreender estratégias de marketing a fim de conseguirem inserir seu "produto" no mercado de verbas para pesquisa, publicações e participações em eventos.

Parece-nos, portanto, que nossas "verdades" andam ancoradas a outros discursos e práticas sociais. Deste modo, apostamos aqui que, a relativização da "verdade" pode nos ajudar a ser mais tolerantes, a abrir e a manter o diálogo com o outro.

Com o discurso da tolerância e da abertura ao diálogo, convido também a pensarmos em nossas orientações em saúde. Conseguimos cumprir todas nossas 
orientações? Prática de exercícios físicos regulares, alimentação balanceada, postura adequada ao sentar-se no sofá para assistir tv, não se envolver com o trabalho a ponto de ficar estressado, consumir bebidas alcoólicas dentro dos limites preconizados, escovar os dentes e usar fio dental após todas as refeições, ser assertivo nos relacionamentos, tomar corretamente os medicamentos receitadas pelo médico. Nunca, mas nunca, extrapolar! ("literalmente ninguém está a salvo de que 'sua conduta' não seja associada a uma enfermidade no próximo número do The Lancet" - CASTIEL; DIAZ, 2007, p. 32) Quais são os limites de nossos discursos preventivos?

Em meio a estas reflexões tive o prazer de dialogar com os escritos de Luis Davi Castiel sobre a saúde persecutória (CASTIEL; DIAZ, 2007, CASTIEL; DARDET, 2007; CASTIEL; GUILAM, 2007). Este autor nos convida a avaliar a efetividade de propostas individualistas de promoção de saúde (denominadas por ele de "saúde persecutória"), adotando o 'estranhamento' a fim de problematizar discursos dominantes que parecem naturalizados, buscando gerar novos olhares. Ele nos lembra que discursos sobre saúde nunca se referem apenas à saúde, mas trazem consigo a ordem econômica, política e social em que são gerados. Desta forma, coloca que são vinculados também a outros interesses. O discurso científico hegemônico sobre álcool e outras drogas coloca estas substâncias como algo a ser evitado, como algo que trará problemas. Macrae (2004) nos lembra que a partir do final do século XIX o controle sobre o consumo de substâncias passa da religião à medicina, priorizando aspectos farmacológicos e compreendendo-as como potenciais criadoras de dependência. O autor nos alerta sobre a falta de estudos que buscam compreender esta questão considerando aspectos culturais. $\mathrm{Na}$ área da saúde, muitas vezes, já iniciamos nossos estudos motivados pela busca de problemas. Quando iniciei este estudo, querendo conversar com mulheres que bebiam, sem pestanejar busquei usuárias de um serviço de tratamento para o uso de álcool. Poderia ter conversado com mulheres que bebiam, trabalhavam, tinham família e amigos e não eram posicionadas como 'usuárias problemáticas'? Pesquisadores (MACRAE, SIMÕES, 2009) escolheram conversar com professores universitários que fumam maconha, optando por estudar "consumidores socialmente incluídos e integrados que não se propõem a abrir mão de seu consumo, já que suas práticas de consumo, mesmo passíveis de estigmatização, não se mostram incompatíveis com seus papéis e seus controles sociais" (VALENÇA, 2008). Ao selecionar participantes que não são posicionados socialmente como 'problemáticos' parece que fazemos outros convites aos leitores: É possível consumir sem ter problemas? Que tipo de consumo é legitimado? 0 que ajuda nesta legitimação? Com isto flexibilizamos nossos discursos e as drogas deixam de ser algo terrível a ser combatido por nós, profissionais de saúde quixotescos (CASTIEL; DIAZ, 2007), e passam a ser compreendidas dentro de um contexto sócio cultural, que legitima algumas ações e marginaliza outras. 
Ao nos tornarmos representantes 'dos que dizem Não!', 'dos que dizem Cuidado!', enquanto profissionais de saúde normatizamos o modo de vida das pessoas. Caso queiram viver de modo diferente, estão se colocando em riscos e possivelmente sofrerão conseqüências. Dizemos o que é certo e o que é errado e trabalhamos com o poderosíssimo mecanismo de culpa. Castiel e Diaz (2007) nos coloca que a culpa pressupõe que haja um julgamento de alguém, uma desaprovação em relação a alguma falha. Além disto, em nossa sociedade valorizamos esta construção, marginalizando os que não se constrangem frente a ela (ex. a ausência de sentimento de culpa é um dos critérios para o diagnóstico de transtorno de personalidade anti-social). No campo da responsabilidade pessoal pela saúde, assumimos nexos causais entre as ações das pessoas e os eventos de saúde, mesmo sem estarmos certos destas conexões. Com isto, individualizamos a questão e construímos o sentimento de culpa pelos eventos (no campo de álcool e outras drogas um exemplo comum é a conexão entre uso de maconha e esquizofrenia ou ainda entre o beber e não ter dinheiro).

E é com base no discurso da responsabilidade pessoal e da culpa que muitas vezes planejamos nossas intervenções preventivas. Segundo Castiel e Diaz (2007, p. 41) "os médicos já não diagnosticam e tratam somente doenças, mas diagnosticam e tratam também riscos... uma grande parte da demanda sanitária é, na atualidade, induzida pela medicalização dos futuros - circunstância que afeta a autonomia". Os autores colocam que além de diagnosticarmos os riscos, também multamos pré-delitos. Um exemplo é a 'lei seca', que pune motoristas por dirigirem embriagados, antes mesmo que estes sofram qualquer acidente ou cometam qualquer delito. Percebemos como nossos discursos em saúde estão inseridos dentro de um discurso maior de individualização e de tentativas de controlar o futuro.

E para encerrar esta discussão, volto às perguntas feitas anteriormente: Conseguimos cumprir com todas nossas orientações? É possível viver assim? E novamente dialogo com Castiel e Diaz (2007) que brincam com o conhecido termo estatístico "estimação de riscos". Os autores propõem inverter este termo para "riscos de estimação", dizendo que todos nós temos nossos riscos de estimação e que estes fazem parte de nossas descrições identitárias. E que, portanto, é preciso cuidar deles com carinho, com cuidado, cientes de que a eliminação abrupta destes pode trazer conseqüências negativas. Chamam também a atenção para o fato de conversarmos tão pouco a respeito do preço pago pela supressão de importantes fontes de prazer e trazem a questão: saúde é sinônimo de segurança?

Este convite a tolerância muitas vezes é aceito no caso de orientações em saúde que não são seguidas, como no caso das dietas. Entretanto, percebe-se uma dificuldade maior em tolerar o não seguimento de orientações que envolvem o consumo de bebidas alcoólicas. Quais os impactos para a saúde de uma dieta não realizada ou da não redução 
do consumo de álcool? A literatura também vem mostrando que as condições de trabalho atuais, com alto nível de competitividade, salários não suficientes para sustentar os padrões de vida almejados, pouca estabilidade e alta exigência, podem levar a situações de estresse, que causam adoecimento, interferindo no indivíduo e na família. Por mais que façamos orientações de saúde visando reduzir o estresse, somos condescendentes com pessoas que continuam a trabalhar sob estas condições. Entretanto, temos mais dificuldades de sermos condescendentes com pessoas que não diminuem ou não interrompem o consumo de bebidas de acordo com o orientado. No primeiro exemplo, utilizamos o discurso de trabalho como responsabilidade, o discurso de cidadania, o discurso religioso, dentre tanto outros, que legitimam o não cumprimento da orientação. Entretanto, no caso das bebidas, utilizamos o discurso da moral, o discurso da motivação interna e outros tantos que culpabilizam pelo não cumprimento da orientação. Como afirmaram Castiel e Diaz (2007), os discursos sobre a saúde dizem respeito também a outras coisas que não apenas saúde.

Com todas estas questões em mente, durante o estudo me perguntei: Como pesquisadora, que posição quero assumir? Entendendo a pesquisa como prática social, ou seja, entendendo que os resultados desta pesquisa não representarão uma realidade e sim ajudarão a criar realidades, resolvi, no decorrer das entrevistas assumir qual realidade gostaria de ajudar a construir. Não me posiciono aqui como 'os que dizem Não!' ou como pesquisadores da área de álcool e outras drogas que trabalham em uma perspectiva proibicionista. Em relação ao tema (álcool e outras drogas), me posiciono como curiosa/afeiçoada pela questão, compreendendo que o consumo não é positivo ou negativo por si só, mas que a legitimação deste se dá nos relacionamentos, dentro de um contexto histórico, social e cultural definido. Também me posiciono como profissional e pesquisadora que respeita os "riscos de estimação" e que, consciente de sua longa imersão em ambientes e literatura que se aproximam das proibicionistas, vem buscando o diálogo com autores que tratam a questão da saúde e de álcool e outras drogas de uma perspectiva compreensiva. Além disto, instigada pelas conversas com minhas colaboradoras, mulheres que trouxeram narrativas doloridas de vida, que se emocionaram ao falar sobre elas, e que se posicionaram como lutadoras e até vencedoras, resolvi que minha pesquisa teria o compromisso de não construir mulheres doentes, vítimas, fracas, desempoderadas. Interlocutora importante neste tomada de decisão foi a socióloga feminista inglesa Elizabeth Ettorre, que nos convida a produzir pesquisas com mulheres usuárias de substâncias que construam imagens de mulheres fortes, imagens estas que as ajudem no processo emancipatório e libertário (ETTORRE, 1997, 2007). Desta forma, fui assumindo no decorrer deste estudo, a posição de "pesquisadora comprometida com o empoderamento das mulheres", posição esta que influenciou diversos momentos da pesquisa. 
Um dos momentos em que esta posição foi importante foi no preparo do material para ser levado para a primeira entrevista. Imprimi duas cópias do termo de consentimento, uma para trazer comigo e outra para deixar com a colaboradora, onde constava meu nome e telefone, caso esta quisesse entrar em contato comigo no futuro. Ao imprimi-las, atentei-me para o nome dado ao estudo que vinha encabeçando o termo de consentimento: "Dependência de álcool: construção do problema na vida de mulheres". Imaginei que ao entregar este termo e fazer a leitura deste com as colaboradoras, estaria posicionando-as como 'dependentes de álcool'. Este convite não me pareceu ético, entendendo que este posicionamento poderia Ihes causar mal estar, vergonha e culpa, descrições que a literatura aponta como sendo comuns em mulheres que recebem diagnóstico de dependência de álcool (ETTORRE, 2007, ALLAMANI et al., 2000). Frente a isto, o título presente no termo de consentimento foi reformulado: "Mulheres e consumo de bebidas alcoólicas: mudanças no decorrer da vida".

Com estes posicionamentos, espero que este estudo seja uma voz, no conjunto de vozes da literatura, que dialoga para contribuir na diminuição dos preconceitos e dos estigmas existentes em relação às pessoas que consomem substâncias, mais especificadamente, às mulheres que consomem bebidas alcoólicas, refletindo teoricamente sobre modos possíveis de compreender suas experiências com as bebidas e em possibilidades de ajudá-las enquanto terapeuta. 

Capítulo 5

Histórias de Miriam 

"FUNDAMENTAL É MESMO O AMOR, É IMPOSSÍVEL SER FELIZ SOZINHO..." TOM JOBIM 



\section{Diferentes formas de narrar a história de Miriam}

Miriam foi nascida e criada em Ribeirão Preto, em uma família de seis irmãos e irmãs.

C: E você nasceu aonde?

M: Em Ribeirão Preto, eu mudei pra minha casa que eu moro hoje faz uns 50 anos, eu nunca mudei de casa.

C: Olha...

M. No mesmo lugar. Moro com meu pai, sou solteira, não tenho filhos.

C. Você mudou pra lá com 4 anos então? E na época foi você...

M. Minha família

C. Tua família...Teu pai, tua mãe, Você tem mais irmãos?

M. Uma irmã mais velha. Depois nasceu os outros. Então, quando eu fui pra lá num tinha nem luz, nada, agora ficou um lugar gostoso, porque Ribeirão Preto cresceu muito.

C. Ai vocês são em quantos irmãos?

M. Seis. Cinco mulheres e mais um homem.

(Linhas 07-16)

Este extrato refere-se ao início de nossa conversa. Pedi que ela me contasse a história de sua vida e, como ela ficou em dúvida de por onde começar, perguntei sua idade e o local onde havia nascido. Provavelmente influenciada pelo discurso dos papéis sociais de gênero em nossa sociedade ocidental, que constroem a normalidade da mulher adulta a partir do casamento e da maternidade, ela se posiciona como 'Miriam que nunca mudou de casa', 'Miriam que mora com o pai', 'Miriam que é solteira', 'Miriam que não tem filhos'. Estes posicionamentos nos contam que Miriam não construiu uma família para si, portanto, constroem a descrição de uma mulher que não desempenha os tradicionais papéis sociais de gênero. Com o uso deste discurso Miriam parece uma mulher que não deu certo. Por outro lado, durante a entrevista percebemos que o modo encontrado por ela para construir-se como mulher em consonância com o discurso dos papéis sociais de gênero, foi posicionar-se como "Miriam cuidadora do pai idoso". Entretanto, no decorrer da entrevista, um dos efeitos do discurso dos papéis sociais de gênero será a desvalorização da posição de "Miriam cuidadora do pai idoso" em prol das posições "Miriam que não casou" e "Miriam que não teve filhos". Em nossa conversa, estes posicionamentos ajudarão a construí-la como uma mulher que fracassou, que ficou solitária e que precisa de mudanças em sua vida, sendo também construídos como parte de seu problema.

Tinha uma mãe que apesar de doente era muito trabalhadora e seu pai, exigente e de pouca conversa, quase não ficava em casa e tinha um caso com outra mulher. 
C. Esta foi uma experiência boa então, que você lembra. Uma experiência legal. E uma experiência ruim é de fazer xixi.

M. E outra de tomar sopa. Que eu num gosto de sopa até hoje.

C. E era obrigada a tomar de merenda?

M. A gente não tomava café da manhã. E assim uniforme era se ganhava. Minha mãe era muito doente, vivia mais no hospital do que...

C. Ah, é, o que ela tinha?

M. Bronquite aguda. Meu pai era trabalhador, muito exigente, muito ali na chincha, né?

... chegou uma época que a gente num tinha nem calcinha para ir na escola, uma precisava emprestar uma pra outro. Foi muito difícil.

C. De tanta dificuldade financeira...Teu pai trabalhava ou não?

M. Trabalhava.

C. Mas o dinheiro num dava pra família toda?

M. Até que dava, a grosso modo, arroz e feijão, roupa a gente se virava. Minha mãe lavava roupa pra fora... mesmo doente carregava roupa assim na cabeça. É, foi uma fase assim muito difícil.

(linhas 42-57)

Neste extrato estamos conversando sobre suas experiências quando criança na escola. Ela constrói estas experiências posicionando-se como 'Miriam que teve uma infância difícil'. Este posicionamento irá ajudar a construí-la como uma pessoa que teve uma infância sofrida, que teve que se adaptar às faltas, dividir com os irmãos tudo o que tinha e criar poucas expectativas em relação à vida.

Em casa, Miriam ajudava bastante e na escola, era uma garota tímida e inteligente.

C. E aí como é que era, na escola?

M. Na escola, (risos), ai... na escola foi terrível.

C. Ah, é, porque?

M. Fazia xixi, de medo.

C. É, medo de que?

M. De pedir pra professora ir na casinha.

C. Entendi.

M. Tava lá estudando e de repente o xixi escorria.

C. No meio da sala?

M. É...

C. E aí, como é que era?

M. Foi terrível. Os amigos riam...

C. Isto aconteceu mais de uma vez?

M. Muitas vezes... uma coisa também que eu recordo de pequeninha é que a professora chegou lá, eu num tinha rádio, num tinha tv, nada, tinha 7 anos e ela perguntou o que que era "indubitavelmente" e eu sem querer falei assim "sem dúvida" e ela falou "parabéns" e eu até hoje não sei porque (risos)

C. (risos) Você nunca esqueceu esta palavra na vida...

M. Não, não sei da onde que saiu, aflorou.

(linhas 23-41) 
Neste extrato, ao relatar sobre a escola, dá ênfase ao relato de uma situação embaraçosa, posicionando-se como 'Miriam criança tímida', posição importante na construção de Miriam como uma pessoa solitária. Relata uma situação de sucesso, posicionando-se como 'Miriam criança esperta', mas desvaloriza-a em seguida, como se não tivesse méritos por isto, como se não tivesse a ver com ela, dando crédito ao acaso para seu sucesso. Esta passagem ajudará a construí-la como uma pessoa para a qual as coisas acontecem em sua vida sem que ela perceba, sem que tenha tido responsabilidade ou crédito. Esta passagem também ilustra um jogo de posicionamentos que aparecerá outras vezes na entrevista, onde ela apresenta dois posicionamentos, um que a constrói de modo negativo e outro que a constrói de modo positivo, e o positivo é desvalorizado em função do negativo.

O pai trabalhava, mas o salário não era suficiente para sustentar a família, portanto, Miriam começou a trabalhar de doméstica aos 10 anos.

C. Você começou a trabalhar com quantos anos?

M. 10 anos.

C. 10 anos, fazendo o que Miriam?

M. Trabalhava de doméstica. Depois dos 14 aos 18 eu tomei conta de uma criança. Nos 18 eu arrumei um serviço de fazer café e estudava, né?

C. O tempo todo você trabalhava e tava estudando também?

M. E ajudava em casa. Se comprava uma roupa tinha que comprar pra todo mundo, sabe.

C. Sei. E ai você trabalhou cuidando de uma criança até os 18 anos e depois disto você foi fazer o que?

M. O que?

C. Foi trabalhar com que depois disto?

M. Fui fazer café numa firma.

C. Ah, numa firma. E você ficou muito tempo nesta firma?

M. Não fiquei 6 meses, ai a gerente desta firma, pediu se eu não queria trabalhar, aprender a trabalhar. Daí um mês eu já tava registrada. Aí não parei mais.

(linhas 109-123)

Neste extrato, Miriam posiciona-se como 'Miriam responsável', 'Miriam preocupada com a família' e 'Miriam trabalhadora'. Estes posicionamentos ajudarão a construí-la como uma mulher que sempre fez de tudo pela família, que sempre cumpriu bem suas responsabilidades no trabalho, que nunca foi egoísta e sempre pensou nos familiares. Entretanto, estes posicionamentos que a fortalecem não ganham papel central em sua narrativa, sendo desvalorizados frente a outros que a vitimizam, como ser sozinha ou ser uma mulher com problemas com bebidas alcoólicas. Deste modo, alguns posicionamentos que poderiam ser usados para compô-la como uma mulher 
forte, bondosa e que venceu na vida são colocados à margem.

Caso a última fala deste extrato fosse mais explorada, poderíamos dialogar com a 'Miriam que cresceu dentro da firma', 'Miram que mostrou seu potencial', 'Miriam que fez um bom trabalho' e com isto buscar construir narrativas que a fortalecessem.

Morava em uma casa bem simples e sempre ouvia sua mãe dizendo do sonho que tinha em ter uma casa melhor. Desta forma, desde que começou a trabalhar, batalhava muito para juntar dinheiro e realizar o sonho da mãe de reformar a casa. Seu pai era contra a idéia e Miriam tinha medo de falar sobre isto com ele.

M. É. E a gente morava numa casa muito simples, então tinha aquela vontade de... fui criada em 2 cômodos... então tinha vontade de melhorar de vida, então não pensava nada... minha mãe falava que tinha o sonho de ter uma casinha boa, não tinha piso, não tinha nada. Então eu comecei a batalhar, batalhar, trabalhava....

C. Você começou a trabalhar com quantos anos?

M. 10 anos.

(linhas 105-110

Neste extrato, Miriam posiciona-se como 'Miriam que queria melhorar de vida', 'Miriam que tinha um sonho', 'Miriam que batalhava pelo sonho' e com isto, constróise como alguém que desde criança assumiu as responsabilidades por um sonho sonhado junto a sua mãe.

Por volta dos 30 anos, com dinheiro para iniciar a reforma, resolveu enfrentá-lo e realizar o sonho da mãe. Então, quando estava tudo pronto, sua mãe faleceu.

C. Ficou nesta firma um tempo...

M. Fiquei. E sempre tentando, querendo reformar minha casa. Mas não tinha como. O medo era tão grande né, e ele não deixava, não deixava. Por fim, quando eu comecei mexer, foi quando ele xingou muito e tal, e neste meio de tempo que tava tudo engrenado minha mãe faleceu.

C. Ah, e faz quanto tempo isto?

M. 20 anos.

C. Nossa, tua mãe faleceu muito nova, então.

M. Com 55.

(linhas 125-132) 
Neste extrato, ela posiciona-se como 'Miriam persistente', 'Miriam que tinha medo do pai', 'Miriam que enfrentou o pai para realizar seu sonho e de sua mãe'. Em seu relato, a realização deste sonho aparece como o maior objetivo de sua vida, desde que tinha 10 anos até a morte da mãe, quando Miriam já tinha passado dos 30 anos.

Ficou tão triste, o choro não saia mais e não conhecia mais sua voz.

C. Nossa. E foi na época você tava conseguindo reformar tua casa...

M. É, e nisto eu já tinha ajudado um monte de gente se casar. Sabe, eu não vivia pra mim... Eu acho que meus problemas começaram quando eu quis cair em mim, quando eu procurei chão pra me encontrar e não achei. Isto eu tô te falando agora porque eu fiz muita psicoterapia, senão não taria nem aqui, não daria nem pra falar.

C. De tão difícil...

M. E, eu nem chorava, vinha até aqui e descia. Não conhecia nem minha voz... Eu fiquei assim depois que eu vivi sozinha com meu pai. Meu pai e uma irmã.

(linhas 133-140)

Neste extrato, estávamos falando sobre a morte de sua mãe. Ela posiciona-se como 'Miriam que sempre viveu pelos outros', 'Miriam que não vivia para si', 'Miriam que não teve apoio quando precisou', 'Miriam que passou a viver sozinha com o pai'. Estes posicionamentos nos contam um pouco sobre a mudança que a morte da mãe representou em sua vida, já que havia passado os últimos 20 anos sonhando o sonho da mãe, e com sua morte, este parece ter perdido o sentido. Apesar de já ter dito em outros momentos que vivia pela família, aqui é a primeira vez que ela constrói esta experiência como negativa, dizendo que não vivia para si. A seguir, constrói a morte da mãe como o momento em que, apesar de viver com o pai e a irmã, passou a viver sozinha. A "Miriam que sempre viveu pelos outros" agora é descrita como a "Miriam sozinha". É a partir deste posicionamento que ela explica o início de seus problemas, que ganharão o nome de crises de pânico e posteriormente, dependência de álcool. Neste extrato as vozes dos psicoterapeutas também aparecem, ajudando a posicionála como "Miriam que ficou sozinha" e com isto, construir o sentido para o início de seus problemas.

Com a morte da mãe e os irmãos já casados, começou a assumir diversas responsabilidades na casa, desde relacionadas ao inventário até cuidados com a casa e com o pai. Na mesma época, ficou desempregada, tendo que fazer bicos para conseguir se manter. 
C. Então eu vou tentar fazer assim uma síntese.

M. Tá certo.

C. Então você me contou que com 4 anos você mudou pra casa, com teus irmãos, 6 irmãos, tua mãe e teu pai, que vocês tiveram uma vida dura, tua mãe ficava muito no hospital, tiveram problemas financeiros, teu pai ficava muito fora, tinha outras mulheres, e tua mãe ficava no hospital, teu pai tinha outra mulher, que engravidou, ela teve um filho, esta mulher morreu, tua irmã foi criada com vocês na casa de vocês, a tua mãe depois veio a falecer, teus irmãos mudaram e você ficou morando, você, teu pai e tua irmã, depois que tua mãe morreu tua irmã tava grávida, o que foi uma bomba, você teve que ajudar a segurar dentro da sua casa, por causa do teu pai, depois nasceu tua sobrinha, vocês ficaram lá até que tua irmã casou e mudou de casa. E ...

M. Quando eu fiquei sozinha, não achei chão.

C. E foi nesta época que tua irmã mudou e saiu que casa que você se sentiu sem chão.

M. Só que até o momento eu tava com ela, eu não bebia. Era social. Ai juntou o desemprego, é, o inventário da casa que ficou tudo nas minhas costas pra eu resolver, o meu pai, também, o processo dele tudo eu tinha que resolver, minha mãe era curadora, a gente não sabia, meu pai sofreu um acidente em 70 e ficou em coma, quase morreu e a mãe desta, desta minha irmã, a mãe dela foi uma das mulheres que ele teve.

C. Entendi, e então assim, esta época foi uma época muito estressante, desemprego, sua mãe faleceu, sua irmã saiu de casa. Você com teu pai, todas estas coisas pra você ter que resolver.

M. O trabalho sobrecarregado...

C. Sobrecarregado, você tendo que lidar com este tanto de coisa.

M. E meu povo sumiu...

(linhas 744-767)

Este extrato foi retirado do final da entrevista, quando faço uma síntese de nossa conversa. Eu a posiciono como 'Miriam que segurou muitas barras da família'; ela posiciona-se como 'Miriam que ficou abandonada à própria sorte'; e então, associamos seu sentimento de solidão e abandono com o momento em que sua irmã saiu de casa. E esta mudança que Ihe trouxe solidão, é associada com a mudança no seu modo de beber, até então considerado como uso social. Deixa de construir seu consumo de álcool como social a partir do momento em que se posiciona como alguém que ficou sozinha. Com fazer uso social na solidão?

Após dois anos, passou em um concurso para trabalhar na área de serviços gerais em um hospital e iniciou o novo trabalho. Sempre foi muito responsável e sempre gostou de realizar seu trabalho da melhor maneira possível.

C. Foi depois?

M. Foi depois, eu fiquei sozinha, onde eu estava trabalhando lá na... era muito serviço e era muito corrido e eu acho que eu já tinha um quadro de ansiedade que eu nem sabia o que era isto, não sabia. Então eu vivia cansada. Se eu recebia um dinheiro eu tinha que pagar no mesmo dia a pessoa, sabe? Hoje eu sei o que é isto, né.

(linhas 182-186) 
Neste extrato, Miriam vinha me contando sobre o início das crises de pânico e pergunto se estas começaram depois que começou a trabalhar na instituição em que estava empregada no momento da entrevista. Posiciona-se como 'Miriam solitária', 'Miriam que trabalhava muito', 'Miriam que ficava ansiosa pra fazer as coisas', 'Miriam que vivia cansada', 'Miriam que tinha que resolver tudo na hora'. Com estes posicionamentos, descreve em nossa conversa, a versão identitária da Miriam que teve crises de pânico: uma mulher só, procurando cumprir suas responsabilidades da melhor maneira, sentindo-se cansada.

O diagnóstico de síndrome de pânico levou-a a um tratamento que provavelmente ajudou-a no controle de seu mal estar e também inseriu vozes de diferentes médicos e fortaleceu o discurso médico-psiquiátrico, presente aqui quando constrói a experiência de querer pagar rapidamente uma dívida como traço de ansiedade, ao invés, de responsabilidade.

Com todas as responsabilidades assumidas, foi sentindo que seu corpo começou a mudar, sua pressão subiu, ela descontrolou-se, sentiu-se sem chão e sozinha e soube então que tinha crises de pânico. Começou um tratamento no hospital.

M. Aí entrei na (instituição em que trabalhava no momento da entrevista). Foi uma coisa muito diferente, muito serviço, muito diferente daquilo que eu tava acostumada a fazer. Que que aconteceu? Meu corpo começou a mudar e um dia sem mais sem menos a minha pressão subiu, eu me descontrolei, não sabia o que era e depois de muita tentativa descobriram que era síndrome de pânico.

C. Ah, tá.

M. Onde que eu entrei pra fazer tratamento na psiquiatria.

C. Ah, tá. Você começou a fazer tratamento pra síndrome do pânico então: você já tinha tido várias crises?

M. Já. É terrível.

(linhas 163-171)

Neste extrato, as posições de Miriam foram: 'Miriam que começou emprego novo', 'Miriam que assumiu novas responsabilidades', 'Miriam que sentiu o corpo mudar', 'Miriam que foi diagnosticada com síndrome do pânico'. Neste relato, estas posições complementam outras já assumidas anteriormente e ajudam a construir sentido para seu diagnóstico de síndrome do pânico. Deste modo, até aqui, a síndrome do pânico foi construída como resultado do novo emprego e das novas responsabilidades, de ter ficado sozinha e de não ter encontrado apoio e foi descrita como mudanças no corpo, aumento da pressão arterial e descontrole. A partir de então, Miriam tem outro posicionamento: 'Miriam paciente de ambulatório de psiquiatria'. 
Após alguns anos de tratamento, a médica disse que poderia tomar um pouquinho de cerveja e disto passou a tomar mais e sem se dar conta, estava tomando todos os dias. Assim também foi com seu pai, que começou a beber por recomendação médica para curar a tontura e bebe até hoje.

C. E quando foi a primeira vez que você tomou bebida alcoólica?

M. Devia ter uns 18 anos.

C. Você tomou na sua casa, tomou fora?

M. Eu nunca tinha tomado na minha casa, tomei fora...

C. Foi fora? E na época que você tomou, você tomava sempre, de vez em quando? Como é que era..

M. Não era todo dia não, só se tivesse um casamento, alguma coisa, aí ia descendo... Aí eu fiz tratamento pro pânico, fiquei um bom tempo sem tomar. Aí falou que podia tomar um pouquinho. Mas do pouquinho, foi um poucão, quando eu me dei conta, eu tava tomando todo dia.

C. Que foi mais ou menos nesta época que você começou tava fazendo tratamento pro pânico?

M. Depois, 4 ou 5 anos depois.

C. Lá pelos anos 2000 então? Até então você não tomava?

M. Não, só se ia num bar, alguma coisa, tomava ali...

(linhas 194-207)

C. E teu pai, esta violência, esta agressividade dele era recorrente ou era de vez em quando?

M. Não dava muito tempo, ele num ficava em casa, ele saía, tinha outras mulheres. Com 10 anos ele tinha uma mulher que tava com a barriga grande e era filho dele, filha. $\mathrm{E}$ a gente ia pra minha tia, que minha mãe tava internada e então passava e eu via aquela mulher gorada. Ela perguntava "Quantos irmãos vocês tem?" "Cinco" e ela "Não, vem vindo mais um." Então estas coisas marcou.

C. Teu pai bebia, Miriam?

M. Não, começou a beber depois dos 40 anos, porque ele sentiu mal...

C. Ele começou a beber depois dos $40 .$. Porque ele sentiu mal, como é que foi?

M. Tontura. Ai o médico falou toma um golinho antes, que passa. E tá até hoje...

C. Que era pra melhorar a tontura...

(linhas 94-104)

No primeiro extrato, conversamos sobre o início de seu consumo de bebidas alcoólicas. Miriam começa a descrever seu consumo diferenciando o modo como bebia antes do tratamento para síndrome do pânico (uso social) e o modo como passou a beber depois do tratamento (uso problemático). Para compor o uso social ela indica que bebia fora de casa, em ocasiões especiais, como casamento. Entretanto, posiciona-se como 'Miriam que sempre gostou de beber', ao dizer "aí ia descendo...". O uso problemático aparece descrito como tendo acontecido alguns anos depois do inicio do tratamento para síndrome do pânico, e é caracterizado como beber dentro de 
casa, beber em grande quantidade, beber todos os dias. Neste trecho, Miriam também se posiciona como 'Miriam que não se dava conta do aumento do consumo'.

No segundo extrato, ela descreve o consumo de bebidas feito pelo pai. Este trecho segue uma conversa sobre o modo como seu pai era violento e batia nos filhos e esposa. Neste momento, ela utiliza o discurso psicológico sobre a influência dos traumas da infância na constituição da personalidade adulta e posiciona-se como 'Miriam que ficou marcada pelas experiências da infância'. Esta posição também ajudará a construir a explicação para a síndrome do pânico e posterior uso problemático de álcool. Motivada pelos discursos sobre a associação da violência com consumo de bebidas alcoólicas entre homens, pergunto se seu pai bebia. Ela constrói o consumo de bebidas alcoólicas do pai como algo não associado às situações de violências, já que aconteceu quando este era mais velho, utilizando o discurso de álcool como terapia medicamentosa, dizendo que este passou a consumir como prescrição médica. Novamente o consumo de álcool é descrito como algo que aconteceu gradualmente, sem que seu pai se desse conta.

Nos dois extratos ela insere a voz do médico legitimando o consumo de bebidas alcoólicas e com isto, sendo co-responsável por este consumo. Descreve o consumo aumentando natural e gradualmente, sem que ela ou o pai tivessem consciência e responsabilidade sobre isto.

Seu pai é hoje sua única família, mas sente que tem muitas responsabilidades com ele. Gostaria que seus irmãos a ajudassem a cuidar dele, mas cada um tomou seu caminho e ela ficou na reserva.

C. Entendi... E neste momento você foi criticada pela tua irmã, ou não?

M. Não.

C. Quando que você sente que você ta sendo criticada, Miriam?

M. Quando a pessoa vem e fala..

C. Mas em que situações que as pessoas te criticam?

M. Assim, como se você tivesse bebendo, "Você é culpada", entendeu? Te culpando.

"Você pára de beber porque senão você vai acabar com a tua vida".

C. Eles te culpam porque você tá fazendo isto. E você acha que a tua família poderia te ajudar de que forma?

M. De que forma? Acho que participando mais, né. Mas eu tenho que por na minha cabeça que minha família agora sou eu e meu pai. Eu achava que eram os irmãos, porque eles casaram, tem a família deles, filhos, então que eu fiquei bem na reserva.... eu queria também que eles se colocassem no meu lugar também, né? Eles falam que não tem culpa que eu não casei.

C. Silêncio....

M. Porque eu deixei tomar, isto foi culpa minha, toda a responsabilidade sobre o meu pai, eu abracei e agora ninguém quer saber. Outro dia eu fiz uma reunião e desci a lenha, né? Aí todo mundo chiou. Aí deu uma melhorada, aí já relaxou outra vez.

C. E quais são as tuas responsabilidades com seu pai? 
M. Ah, eu levo ele no médico, eu cuido da roupa, da comida dele. Ah, ele não tem ajuda de ninguém, nem financeira, nem ninguém se preocupa com o que ele ta precisando. Entendeu? Ele tem uma promessa de domingo, faz 50 anos que ele tem esta promessa de ir na 7 Capelas de domingo, aí eu falei pra ele conversar com a santa e alterar porque todo domingo ter que levar, é duro, não. Porque eu também tô pagando a promessa. Fala pra santa, já passou tanto tempo, agora é era de comunicação, né? Fala com a santa que não tem problema não.

(linhas 439-463)

Este trecho segue uma conversa em que Miriam me conta que foi viajar com a irmã e que beberam durante a viagem. Anteriormente, ela havia me dito que sua irmã criticava-a por consumir bebidas alcoólicas, resolvo então perguntar se isto também aconteceu durante a viagem. Ela diz que não, dando a entender que para a irmã, beber durante uma viagem não era problema. Tento explorar a construção contextual do uso de álcool como problema, perguntando em quais situações é criticada. Ela traz a voz da irmã, que utiliza o discurso de responsabilidade individual pela saúde para abordar o assunto com ela. Com o uso deste discurso, Miriam é posicionada como 'Miriam que tem culpa pelo consumo de bebidas alcoólicas', 'Miriam que vai acabar com sua vida', 'Miriam que é a única responsável por sua saúde'. A fim de buscar possibilidades menos individualizantes, pergunto sobre como sua família poderia ajudá-la, e ela diz que ajudariam se participassem mais. Entretanto, em seguida, posiciona-se como 'Miriam que não tem família' e 'Miriam que ficou na reserva', inserindo novamente a voz dos irmãos que a responsabilizam por não ter casado. $A$ posição 'Miriam que é a única culpada por não ter se casado' irá dar espaço para seu próximo posicionamento de 'Miriam que assumiu todas as responsabilidades pelo pai'. Neste trecho, a versão identitária de Miriam que vem se construindo, com o auxílio das vozes dos irmãos e do discurso da responsabilidade individual, é a de uma pessoa que é a única culpada por sua vida (pelo consumo problemático de bebidas, por não ter casado, por ter assumido as responsabilidades com o pai, por não ter com quem dividir a responsabilidade por seus problemas) e como alguém que está sozinha com sua culpa. Em seguida, descreve uma situação em que tentou posicionar-se diferente, como 'Miriam que precisa de ajuda para cuidar do pai', mas relata que os irmãos não aceitaram este posicionamento. 
Às vezes cansa-se com isto, gostaria que sua vida mudasse, que tivesse uma nova paixão e que pudesse recomeçar em uma casa nova.

C. E era uma pessoa que você gostava?

M. Apaixonada. Só de ver... quase morria... estas emoções.... eu num tenho mais... era tão bom, né?

C. E aí, aconteceu. Então você tá precisando se apaixonar de novo, né?

M. Ah, eu acho tão difícil se apaixonar...

(linhas 568-572)

C. E o que que você acha que tava acontecendo na tua vida nos momentos que você bebeu mais, ou menos.

M. Acho que faz tanto tempo que não acontece alguma coisa interessante que eu não tô preocupada. Queria que acontecesse alguma coisa pra mudar (dá ênfase). Podia mudar de casa né?

C. Já pensou nisto, de mudar de casa?

M. Não tenho coragem.

C. Não? Porque é uma mudança grande, mesmo, né? É uma mudança que pode ser boa, também, né?

M. Ai, Clarissa, teve uma época, eu nunca pensava na dureza que eu passei de pequena. Hoje eu tô muito bem em relação a isto, hoje eu já comprei minha casa. Mas na hora que foi pra mudar, ele, meu pai não quis ir comigo. E eu tenho certeza que lá sozinha eu não ia ficar legal. Como é que eu vou viver lá com a cabeça aqui?

C. Então você tem uma casa?

M. Tenho.

C. E teu pai não mudaria com você pra outra casa?

M. Ele acha um absurdo eu querer ir, não respeita.

C. Então você optou por ficar lá.

M. É, tem hora que dá vontade de largar tudo, sabe, sumir, viver minha vida, não pensar em pai, em nada, deixa os outros se virar. Mas eu não consigo.

(linhas 479-498)

O primeiro extrato vem de um trecho de nossa conversa onde ela me contava sobre seu primeiro beijo e sua primeira paixão. Ao falar sobre o passado, posiciona-se como 'Miriam que era apaixonada' e 'Miriam que tinha fortes emoções' e contrapõe estas experiências com o presente, posicionando-se como 'Miriam que não tem fortes emoções', 'Miriam que não se apaixona mais'. Estas posições irão ajudar a construir a descrição de uma mulher que não tem mais paixões na vida, não tem emoções que impulsionem sua vida, que não tem motivação para mudar.

O segundo extrato vem de um trecho de nossa conversa onde busco explorar os contextos em que consome bebidas alcoólicas, buscando construções para o aumento ou diminuição do consumo. Ela posiciona-se como 'Miriam entediada com a vida', 'Miriam desesperançosa', 'Miriam que anseia por mudanças'. Estes posicionamentos irão ajudar a construir a descrição de uma mulher que está entediada e que precisa 
de algo que Ihe dê motivação. Instigada por este convite, pergunto se já pensou em mudar de casa, ao que ela se posiciona como 'Miriam que não tem coragem para mudar', seguida por 'Miriam que venceu as dificuldades financeiras' ao dizer que tem casa própria, e 'Miriam que não moraria sozinha', 'Miriam que se preocupa com o pai', 'Miriam a quem o pai não respeita as vontades'. Entendendo que estas posições poderiam construir a descrição de uma mulher que é vitima de suas circunstâncias procuro utilizar o discurso da autonomia e posiciono-a como 'Miriam que optou por não se mudar'. Frente a isto, ela mostra a tensão entre dois posicionamentos: um posicionamento abafado - 'Miriam que tem vontade de mudar' e um posicionamento já muito utilizado - 'Miriam que não consegue deixa de pensar na família'.

No jogo de posicionamentos presente nestes extratos, a descrição de uma mulher que já teve paixões e que já venceu as dificuldades financeiras, descrição esta que poderia empoderá-la para fazer mudanças em sua vida, é abafada pela descrição de uma mulher que não se apaixona mais, que está entediada, que se preocupa demais com seu pai e que não tem coragem para mudar, descrição esta que a imobiliza e invalida possibilidades de mudança.

No segundo extrato, Miriam apresenta um sonho: mudar de casa. Como seria se neste momento eu tivesse aproveitado a abertura dada por ela de falar sobre sonhos e tivesse explorado isto ainda mais: "Miriam, vamos pensar que você acorda um dia e percebe que um milagre aconteceu. Você mudou de casa. Qual seria a primeira coisa que você notaria de diferente naquele dia e que the indicaria que o milagre aconteceu? Como seria este seu dia? O que você estaria fazendo? Que pessoas notariam esta diferença? O que elas perceberiam diferente em você que as diria que este milagre aconteceu?" Estas são questões sugeridas pela Terapia Focada na Solução a fim de convidar o cliente a construir o futuro desejado e a construir alternativas para seu problema. Será que com o uso destas questões poderia ter aberto outras possibilidades?

Mas não vê muita saída, não tem com quem conversar e aos 54 anos mora com o pai, é solteira e não tem filhos. Sente-se sozinha. 
C. Você continua fazendo acompanhamento no hospital então?

M. Tô, tô, só que tô faltando. Eu quero voltar lá quando eu tiver, é, falta esforço meu. Entendeu?

C. É, você sente isto? Porque Miriam?

M. Chega lá eu prometo um monte de coisa, saio de lá e dá tudo errado.

C. Então, mas o que é que acontece quando você sai de lá, o que você acha?

M. Eu me tranquei de um jeito tão grande dentro de casa, que eu não consigo sair e fazer aquilo que eu fazia antes. Eu gostava de dançar, eu... eu sempre fui uma pessoa de poucos amigos, vinha da escola sozinha, então isto daí já é uma coisa minha, eu, eu acho que piorou.

C. E você tá mais fechada ainda...

M. As pessoas que eu poderia assim ter, ter um grupo de amigo, não tenho, eu tinha antes, mas cada um casou, foi tomar conta de sua vida, então eu perdi assim aquela referência que eu tinha

C. Entendi. E desta forma você acaba ficando mais em casa...

M. E, é o que eu falei pros médicos lá: eu entrei dentro de uma toca, eu vou trabalhar, e tudo, mas aquela parte, aquela outra Miriam, que precisava ressociar que fala?

(linhas 215-230)

Este extrato é parte de nossa conversa sobre o tratamento que faz no serviço ambulatório, logo após ela dizer que estava desanimada com o tratamento. Ela utiliza o discurso psicológico da motivação interna, de que o tratamento só funciona quando a pessoa quiser mudar e para explicar sua falta de motivação com o tratamento, posiciona-se como 'Miriam que não se esforça'. Peço que ela me explique melhor este posicionamento, ao que ela se posiciona como 'Miriam que promete, mas não cumpre'. Convido-a a refletir sobre o contexto deste posicionamento e ela se posiciona como 'Miriam que se isolou' em contraposição com a 'Miriam que saia e gostava de dançar'. Entretanto, utiliza-se do discurso psicológico da construção da personalidade na infância e posiciona-se como 'Miriam que sempre teve poucos amigos', somando à sua construção de pessoa sozinha o relato de que as pessoas que Ihe eram próximas casaram e foram tomar conta de suas vidas, posicionando-se como 'Miriam que perdeu suas referências'. Com isto, constrói seu pedido aos médicos: precisa se ressocializar!

No início deste extrato, seus posicionamentos constroem-na como alguém que não se esforça no tratamento e que promete coisas que não cumpre, construções estas que estão relacionadas com o discurso da motivação interna e da responsabilidade pessoal. Com estas construções, as possibilidades de mudança ficam limitadas, ela se desanima e falta do tratamento. Entretanto, traz para a conversa um posicionamento do passado, que Ihe constrói como alguém que já teve amigos e que gostava de sair. Com isto, faz um pedido que parece promissor na construção da mudança: precisa de novos interlocutores, precisa expandir seu mundo social. 
Procurou companhias nos tratamentos, estando há aproximadamente 10 anos em serviços ambulatoriais. Neste tempo, teve lindos encontros, com pessoas que a acolheram, entregaram-se às conversas, ajudaram-na a se sentir a pessoa mais maravilhosa do mundo.

C. E se a gente fosse montar um serviço pra trabalhar com mulheres, que sugestão você daria? Se a gente chamasse, Miriam, com a experiência que você tem, tudo, ajuda a gente a pensar, o que não poderia faltar neste serviço, como este serviço deveria ser?

M. Ah, qualquer serviço que mexe com a auto-estima, que faz a pessoa crescer, se sentir. Eu já senti isto.

C. Isto é uma coisa importante?

M. Já senti isto nos tratamentos que eu fiz.

C. Sentiu?

M. Me senti a pessoa mais maravilhosa do mundo!

(linhas 608-616)

C. Não é? E quando você vai no hospital você sente que o pessoal te ouve?

M. Ouve. Mas tem muita gente que num ouvia, tem gente que mais identificação né?

C. E o tratamento que você fez lá, você teve no ambulatório, você fez psicoterapia, né?

M. 1 ano.

C. 1 ano?

M. Com um médico que eu fiquei doida, ele foi embora para João Pessoa e eu queria ir atrás dele. Foi meu ídolo.

C. Olha só.

M. É, pelo nome dele eu descobri o telefone.

C. Como que ele chama?

M. Pedro.

C. Conheço o Dr. Pedro.

M. Conhece, como?

C. De quando ele tava aqui, eu estudava psicologia na época. Eu perguntei o nome dele porque você falou João Pessoa e eu lembro que ele era de João Pessoa.

M. Aquele homem me tirou eu do chão. Porque ninguém acertava os remédio, menina, foi assim uma coisa muito bonita, no fim do ano ele chorou, eu chorei e do jeito que ele me pegou, assim, do jeito quando acabou, sabe?

C. Ele é uma pessoa muito especial né? Eu também, depois que ele foi embora pra João Pessoa, eu não o vi mais, mas eu tive com um colega meu a semana passada que mora em João Pessoa e perguntei, né, um colega psicólogo, e ele falou, olha, Clarissa, eu também não vejo, mas eu ouço falar muito dele em João Pessoa, é uma pessoa que está...

M. Muito humano.

(linhas 636-658)

O primeiro extrato tem início com um convite que faço a Miriam, posicionando-a como 'Miriam que tem experiência para dar sugestões', para que descrevesse como deveria ser um serviço voltado para o público feminino. Sem pestanejar, ela sugere um serviço que trabalhe com a auto-estima e que ajude a pessoa a desenvolver seus potenciais. Ao dizer que já esteve em tratamentos assim, posiciona-se como 'Miriam que já se sentiu bem', 'Miriam que já se sentiu a pessoa mais maravilhosa do mundo'. 
Seguindo as sugestões da Terapia Focada na Solução (PICHOT, SMOCK; 2009; de SHAZER, 2004), poderia ter perguntado aqui: Como seria sua vida se você estivesse se sentindo como a pessoa mais maravilhosa do mundo? ou O que você estaria fazendo se estivesse se sentindo a pessoa mais maravilhosa do mundo? ou Pense nos momentos em que você se sentiu a pessoa mais maravilhosa do mundo. O que você fez para se sentir assim?

O segundo extrato acompanha um diálogo em que ela diz se sentir bem por ter sido ouvida por mim na entrevista. Na busca de explorar outros contextos de escuta possíveis, pergunto sobre seus espaços de tratamento. Para descrever o tratamento de sucesso, ela foca na sua relação com o médico, que se tornou seu ídolo. Apesar da descrição de 'ídolo' remeter a alguém que está distante e inacessível (o que aconteceu ao término do tratamento), ao descrever a relação que teve com o terapeuta aponta para um relacionamento próximo, posicionando-o como 'terapeuta muito humano', 'único terapeuta que acertou sua medicação', 'terapeuta que chorou com ela ao se despedir'. Avalia este tratamento como sendo de sucesso, já que saiu dele de modo diferente do que entrou.

E também conheceu médicos que Ihe davam tarefas e exercícios que não compreendia bem e que the disseram que tinha que andar sozinha. Às vezes acha que vem passando pela vida dormindo.

C.... ô Miriam, e nesta época que você fez tratamento aqui, você tá em tratamento ainda, né, se a gente pudesse pensar, o que você acha que foi melhor no teu tratamento, sabe, o que você acha assim, "olha isto é legal no tratamento, faz bem, isto eu não gostei de fazer no tratamento, não foi bom."

M. O que eu não gostei no tratamento? Foi de fazer esta lista diária, o que você bebe, quais as vantagens e desvantagens.

C. Isto você não gostava? Não tava dando certo? Porque, o que é que era que eles pediam pra você fazer. Uma lista...

M. Qual a vantagem do uso de álcool e as desvantagens. Até hoje eu não consigo assimilar os dois.

C. Entendi, você tinha dificuldade de pensar o que é vantagem e desvantagem. O que é que você escrevia?

M. O que eu escrevia? Uma das vantagens é que eu ficava assim leve, a bebida sempre me deixou, assim mais... se eu fosse num baile dançar, eu tomava uma coisinha pra ficar mais solta.

C. E isto você colocava como uma vantagem então, e o que você colocava como desvantagem?

M. Como desvantagem? Ir num baile e sair já meio alegrinha, isto é desvantagem.

C. Você tem ido a baile?

M. Não.

C. Depois desta época que você falou que você começou a se fechar, você parou de ir? E faz quanto tempo?

M. 6 anos. 
C. Tá, então você me contou uma vantagem e uma desvantagem de 6 anos atrás, de quando você ia no baile. E você coloca isto até hoje no papelzinho das vantagens e desvantagens?

M. Eu num ponho, nem pego mais o papel.

(linhas 499-524)

C. E, ô, Miriam, depois você voltou no serviço mais alguma vez?

M. Fui com Dr. Luis. Mas não vale a pena...

C. Porque seria legal, né?

M. Ele falou que eu tenho que me virar sozinha, andar com minhas próprias pernas.

C. Porque eu tô pensando que você falou assim, que faz tempo que você não conversa com alguém, que seria bom ter alguém pra escutar, né? Então eu fiquei pensando se não seria bom você procurar alguma psicoterapia de novo...

M. Não.

C. Não? Porque não?

M. Ah, já fiz bastante.

C. É, foram eles que falaram ou foi você que pôs isto na cabeça?

M. Foi eles que falou (risos nervosos)

C. Ah, é, né? Você que tá pondo isto na cabeça...

M. Você começa ver coisas... Mas tem muita gente que passa pela vida e tá dormindo e isto é verdade, né....

(linhas 687-701)

No primeiro extrato, convido-a a pensar sobre o tratamento, avaliar os pontos positivos e negativos deste. Ela começa a descrever o que não gostava no tratamento, referindo-se a um exercício (balança motivacional) muito utilizado e recomendado pela literatura de álcool e outras drogas que visa eliciar a motivação do paciente para mudar seu comportamento através da listagem das vantagens e desvantagens do consumo. Estas devem ser colocadas de lados opostos da balança, que deverá ser mais pesada no lado das desvantagens do consumo, auxiliando o paciente a visualizar a importância de mudar o modo em que bebe e assim, aumentar sua motivação neste sentido. Miriam justifica não ter gostado desta atividade por não compreendê-la. Pergunto o que ela escrevia e ela me diz que uma das vantagens de beber era sentirse mais leve, remetendo este sentimento a quando saía para dançar. Para construir a vantagem, utiliza o discurso de álcool como facilitador das relações sociais, entretanto, esta descrição refere-se a algo que ficou no passado. Pergunto sobre o que colocava como desvantagem, ao que ela descreve uma situação que ilustra o discurso de álcool levando a falta de controle comportamental, situação esta que também faz parte de seu passado. Questiono o uso de discursos e situações que não se aplicam mais a sua vida atual e ela logo se explica: "eu num ponho, nem pego mais o papel". Ao não realizar as atividades propostas no tratamento, os posicionamentos que se tornam disponíveis são 'Miriam que é resistente ao tratamento', 'Miriam que precisa se esforçar mais', 'Miriam que primeiro precisa 
decidir mudar para depois voltar ao tratamento'. Este trecho nos auxilia a compreender um pouco a origem de suas descrições enquanto paciente e as descrições feitas a mim por um profissional do serviço ao saber de meu interesse em entrevistá-la.

O segundo extrato vem após o relato sobre seu tratamento de sucesso, em que se sentiu a pessoa mais maravilhosa do mundo. Motivada por estas descrições, pergunto se ela deu continuidade ao tratamento no serviço em questão. Ela responde afirmativamente, dizendo-me o nome do novo médico e descreve esta experiência como algo que não valeu a pena. Pensando o tratamento como uma opção de espaço de escuta, inundada pelo discurso da medicalização, que transforma o serviço de saúde como espaço para a resolução de todos os problemas, digo que voltar para o tratamento seria uma opção interessante. Ela traz a voz do médico que a recebeu, dizendo que precisava se virar sozinha, andar com as próprias pernas. Esta voz nos diz que o serviço já ofereceu o que podia, que é hora dela procurar ajuda em outro lugar. Só que Miriam não sabe onde procurar.

A Miriam que acabou de sair de um tratamento onde descreve o terapeuta como sendo muito humano e acolhedor, construindo-se como 'Miriam, a pessoa mais maravilhosa do mundo', entra em uma nova relação onde foi posicionada como 'Miriam que já fez muita terapia', dando sustentação para 'Miriam que precisa andar sozinha', construindo-se como 'Miriam que vem passando pela vida dormindo'. Este é o tratamento avaliado como não valendo a pena, já que se sente sozinha, acuada e sem opções.

Sente que tem um inimigo dentro de si, com quem é muito difícil lutar, portanto, melhor aceitar.

C. O Miriam, e aí, é, neste dia então, você passou mal e você decidiu que não ia beber e você não bebeu. E neste dia então, você acha que você sentiu falta da bebida?

M. Não muito pelo contrario.

C. Você acha que fez bem pra você?

M. É uma luta que eu tenho comigo, né. Ai, ai, o único inimigo que eu aceito é este. É tão difícil lutar com ele.

C. E este inimigo é o que? O que você tá chamando de inimigo?

M. Tá aqui dentro, dentro de mim mesmo.

C. Ô, Miriam, e antes da semana passada, você lembra de algum outro período que você ficou uns dias sem beber, ou você diminuiu...

M. Que eu diminui... só se tiver uma coisa muito importante que eu tiver que fazer e ter que dirigir (diz isto com ênfase).

C. Então você não bebe... Se você tem que dirigir, você não bebe. Ou quando tem uma coisa muito importante, o que é uma coisa muito importante? Ah, um aniversário de algum sobrinho e tudo. Ai eu olho pro carro... (risos) 
Neste extrato, eu procurava explorar os momentos em que ela não havia consumido bebidas alcoólicas, procurando conhecer como estes eram construídos. Ela relata que na semana anterior havia ficado um dia sem beber, já que havia passado mal no dia anterior. Utilizo o discurso médico da síndrome de abstinência, ao perguntar se ela não havia sentido falta da bebida. Ela diz que se sentiu bem sem beber e de posse do discurso bélico, muito usado na área de álcool e drogas (luta contra o álcool, guerra contra o álcool, batalha contra o álcool) e do discurso psicológico da motivação individual, ela se posiciona como 'Miriam que é mais fraca que o inimigo', 'Miriam que perdeu a batalha', construindo-se como uma pessoa fraca, derrotada, sem forças para agenciar sua vida, estando nas mãos deste forte inimigo que está dentro dela. E se neste momento, eu tivesse perguntado: "Miriam, o que você fez neste dia em que ficou sem beber? Vamos recordar este dia, desde a hora em que você acordou?" Será que ela falaria sobre estar nas mãos do inimigo ou poderíamos explorar os recursos que utiliza quando não quer beber?

Continuei a explorar a possibilidade de outros relatos de momentos em que não consomiu bebidas alcoólicas e ela explica que não bebe em ocasiões importantes em que terá de dirigir, dando como exemplo, o aniversário do sobrinho. Neste relato, posiciona-se como 'Miriam que não bebe em ocasiões importantes', 'Miriam que não bebe se tiver que dirigir', abrindo a possibilidade de construir-se como alguém que tem agenciamento, que tem controle sobre o consumo, que tem força. Ela poderia beber e não ir ao aniversário do sobrinho, caso estivesse nas mãos do inimigo que está dentro dela. Ela deixa de beber se isto valer a pena e se tiver algo importante para fazer. Ela deixa de beber se tiver que dirigir. Ela mostra agenciamento e controle. E se neste momento, eu tivesse dado ênfase ao seu relato de exceções? "Miriam, você está me dizendo que tem controle sobre a bebida. Isto é muito legal. Em ocasiões importantes para você, que você não quer perder e sabe que terá que dirigir, como no aniversário de um sobrinho, você não bebe. Isto mostra que você tem controle sobre seu inimigo. Quais outras ocasiões são assim importantes para você?"

Aos finais de tarde, sai para passear, cada dia em um mercado diferente, pois já sentiu o preconceito ao comprar suas latinhas de cerveja. Volta para casa, senta em sua cozinha, ouve seus cds e deixa a cabeça vagar, sem pensar em nada. 
C. A que horas do dia geralmente que você toma?

M. À tarde.

C. À tarde... À tarde depois do almoço?

M. Não, 6 horas, 7 horas.

C. E como é que é? Você tá na tua casa, vai lá, pega uma latinha...

M. Não, não. Eu vou buscar a latinha, ainda tem esta.

C. Ah, tá. Você vai comprar, volta.

M. É como seu eu fizesse um passeio, né

C. Entendi. Todo dia você vai e compra.

M. Que é a hora que eu não tô pensando na minha vida

C. A hora que você dá um passeio. E você vai aonde comprar?.

M. Cada dia vou num lugar, pra não marcar muito (risos nervosos)

C. Marcar o que?

M. O preconceito. Eu mesmo tenho preconceito de comprar. (risos nervosos)

C. Ah, você se sente mal de fazer isto? Já aconteceu alguma situação de alguém te falar alguma coisa?

M. Já, já.

C. Quem te falou?

M. O dono do bar mesmo.

C. E o que você acha que o dono do bar pensa do jeito que você bebe?

M. Eu não procurei saber não.

C. Mas o que você imagina, do que ele te falou?

M. Tava criticando, né? Não sei se é por bem ou por mal.

C. E o que você respondeu pra ele quando ele falou isto?

M. Não falei nada, falar o que? Só não voltei mais.

C. E ai, então, você faz isto, você vai em vários lugares diferentes... Mas aí, Miriam, você vai, compra a latinha, volta pra casa e você toma tua cerveja fazendo o que, limpando a casa?

M. Não, não. Ouvindo o rádio. Radio, não. Cd! As musicas ...

C. Você senta aonde?

M. Na cozinha.

(linhas 263-292)

Neste extrato, quero conhecer como o consumo de bebidas alcoólicas está inserido em sua rotina. Ela descreve que bebe aos finais de tarde, posicionando-se como 'Miriam que sabe a hora de beber' e constrói sua saída para comprar a cerveja como seu passeio diário, o momento em que não está pensando em sua vida. Esta construção quase bucólica, é interrompida pelo relato de que cada dia compra cerveja em um local diferente, trazendo para a entrevista a voz do dono do bar que a criticou por comprar cerveja todos os dias. Posiciona-se então como 'Miriam envergonhada', 'Miriam que está fazendo coisa errada', 'Miriam que precisa disfarçar seu consumo'. Estes posicionamentos ajudarão a construí-la, em nossa conversa, como uma pessoa que faz coisa errada, que tem culpa por isto e que é inferior aos outros.

Continuo a conversa sobre sua rotina de consumo e pergunto se bebe enquanto limpa a casa. Ela rapidamente me diz que não, e novamente dá um tom romântico ao consumo, dizendo que senta em sua cozinha, fica ouvindo suas músicas e bebendo. A bebida alcoólica é construída aqui como uma companhia, para uma mulher que a todo o momento descreve-se como solitária. 
Fez uma limpeza em sua cabeça. Não se lembra dos bailes, nem do primeiro beijo, nem de quando respondeu certo à professora na escola. Foram acontecimentos que não sabe bem explicar ou que de tão efêmeros, parece que nem existiram. Não tem mais estas emoções e acredita que as pessoas precisam ter paixão por alguma coisa. Será que depois de tantos anos sozinha toleraria um sapo, um príncipe, alguém que viesse para salvá-la, que a tirasse dali e oferecesse a felicidade eterna?

C. Isto é uma coisa que te estressa também, né?

M. É muito cansativo. Nestes 20 anos que minha mãe faleceu foi muita coisa...

C. Muita coisa....

M. A morte de um sobrinho meu também, que eu era super ligada, aconteceu nesta época também, eu tava trabalhando, tava de experiência no hospital, então foi um choque..... Você quer falar alguma coisa, uma felicidade que eu tive na minha vida?

C. Fala

M. Só falar coisa ruim não dá. Eu tinha 18 anos quando eu dei o primeiro beijo, eu não dormi de tanta felicidade (risos)

C. Ah, é?

M. Mas o cara já era noivo...

C. Era noivo...

M. Ai, isto pra mim foi...

C. E era uma pessoa que você gostava?

M. Apaixonada. Só de ver... quase morria... estas emoções... eu num tenho mais... era tão bom, né?

C. E aí, aconteceu. Então você tá precisando se apaixonar de novo, né?

M. Ah, eu acho tão difícil se apaixonar...

C. Você já se apaixonou muito na vida, ou não?

M. Já, pelas pessoas mais erradas que você pode imaginar...

C. Errada por que, Miriam?

M. Ah, todo mundo na minha casa casou, os namorados que eu arrumei era tudo problemático.

C. E hoje, você gostaria de arrumar um namorado?

M. Eu acho que eu vou ser muito exigente, passou muito tempo. Muito tempo sozinha, eu não sei se eu vou saber ficar dando satisfação... mas pode acontecer, né? Tô esperando... um sapo... príncipe, eu não sei. Sabe que eu fiquei muito tempo esperando, né? Acreditava que vinha um. Que viesse alguém me salvar, me tirar dali, e que eu ia ser feliz pra sempre. Mas a gente tem que ser feliz sozinha primeiro, né?... Mais alguma coisa?

C. Eu tô pensando assim, quando você falou que você senta lá no teu banquinho, tomando tua cerveja, ouvindo tua musica, pra onde é que tua cabeça vai?

M. Onde é que vai? Pra lugar nenhum...

C. Mas a gente não consegue ficar sem pensar, é impossível, né?

M. Mas nada me lembra outra pessoa, fiz uma limpeza aqui pra cima, que....

(linhas 555-587)

Este extrato vem depois de uma conversa em que me conta que seu pai tem soluço crônico e que isto a deixa muito cansada. Posiciona-se como 'Miriam que teve uma vida difícil depois da morte da mãe' e relata a experiência da morte de um sobrinho. Estas descrições irão também explicar as crises de pânico que ocorreram em seguida. 
Então, Miriam me faz um convite: vamos falar sobre coisas felizes? Posiciona-se como 'Miriam que teve felicidades na vida' e conta sobre seu primeiro beijo, sobre sua primeira paixão. Entretanto, logo em seguida, posiciona-se como 'Miriam que escolheu errado sua paixão', ao dizer que este era noivo, e como 'Miriam que se decepcionou no amor', falando sobre seu sofrimento com a situação. Estas posições ajudarão a construí-la, em nossa conversa, como uma pessoa desiludida, sem paixões e sem emoções. Ofereço a ela uma nova posição 'Miriam que precisa se apaixonar' e ela, presa ao posicionamento de 'Miriam que escolhe errado sua paixão', justifica o porquê de não ter se casado, já que seus namorados eram todos problemáticos. Pergunto sobre o desejo de arrumar um namorado e ela posiciona-se como 'Miriam que ficou exigente', 'Miriam que se acostumou a ser sozinha' para dizer que provavelmente não conseguirá arrumar outro. E em seguida utiliza-se do discurso do amor romântico, posicionando-se como 'Miriam que está esperando outra paixão', 'Miriam que espera por alguém que a salve', 'Miriam que gostaria de ser feliz para sempre'. Este sonho é interrompido pelo discurso do individualismo, que diz que antes de arrumar um amor, a pessoa deve ser feliz sozinha. Como não sabe como ser feliz sozinha, fecha a possibilidade de encontrar novo amor. Sentindo-se em um beco sem saída, me pergunta: "Mais alguma coisa?" Insisto na construção de 'Miriam como alguém que sonha' e pergunto sobre seus devaneios quando senta para beber, ao que ela se posiciona como 'Miriam que não tem com quem sonhar'.

Para que sair de seu esconderijo?

C. Você continua fazendo acompanhamento no hospital então?

M. Tô, tô, só que tô faltando. Eu quero voltar lá quando eu tiver... é, falta esforço meu, entendeu?

C. É, você sente isto? Porque Miriam?

M. Chega lá eu prometo um monte de coisa, saiu de lá dá tudo errado.

C. Então, mas o que que acontece quando você sai de lá, o que você acha?

M. Eu me tranquei de um jeito tão grande dentro de casa, que eu não consigo sair e fazia aquilo que eu fazia antes. Eu gostava de dançar, eu... eu sempre fui uma pessoa de poucos amigos, vinha da escola sozinha, então isto daí já é uma coisa minha, eu, eu acho que piorou

C. E você tá mais fechada ainda...

M. As pessoas que eu poderia assim ter, ter um grupo de amigo, não tenho, eu tinha antes, mas cada um casou, foi tomar conta de sua vida, então eu perdi assim aquela referência que eu tinha

C. Entendi. E desta forma você acaba ficando mais em casa...

M. E, é o que eu falei pros médicos lá: eu entrei dentro de uma toca, eu vou trabalhar tudo, mas aquela parte, aquela outra Miriam, que precisava ressociar que fala?

C. Ressocialização.

M. Está escondida. 
C. Então, o Miriam, e assim, eu tô pensando, você falou que no momento tá reclusa e tudo. Tem alguma coisa, você procurou, algo que você gosta de fazer, o que você gosta de fazer?

M. Eu gosto de cinema, mas não tenho coragem de ir.

C. Porque não tem coragem?

M. Sozinha, tudo o que eu faço é solitário....

(linhas 817-821)

Em nossa conversa, os posicionamentos de Miriam descrevem uma mulher sozinha, que vive sem referências sociais e afetivas, e em sua narrativa, estas descrições ajudam explicar seu consumo de bebidas alcoólicas. Estas descrições também invalidam outras possibilidades de ação, já que constroem uma narrativa saturada pelo problema, onde não há espaço para outras possibilidades. Miriam diz que o que faria bem a ela seria ter relacionamentos, entretanto, não sabe como consegui-los. Procurou nas terapias, mas foi incentivada a andar sozinha pelos médicos. $\mathrm{Na}$ entrevista, também a incentivo a fazer as coisas que gosta sozinha. Está encurralada: sente-se triste e sozinha porque não tem companhia, mas por não ter companhia não sabe como sair de sua tristeza e solidão.

Como encontrar coragem para buscar sua felicidade sozinha, para pensar mais em si, para encontrar a fortaleza que está dentro dela, se faz tanto tempo que não acontece nada de interessante?

C. E já teve momento, Miriam, que você ficou sem beber uma semana, um tempo?

M. Já

C. O que tava acontecendo na tua vida neste momento, que você deu um tempo, parou de beber, diminuiu?

M. Eu não sei te falar. Mas quando eu não bebo, eu não sinto falta nenhuma, eu fico bem comigo mesmo. É uma bola de neve que não dá pra explicar.

C. Então, e no momento atual você ta bebendo?

M. Tô.

(linhas 372-379)

C. Você já conversou sobre isto com ele?

M. Sobre o que?

C. Sobre o teu relaciomento com bebida, com teu pai?

M. Não, ele sabe.

C. Então, ele sabe, mas vocês já conversaram sobre isto, quando ele fala "manera", você responde alguma coisa, ou não?

M. (ruído) ...remédios controlados...Tem uma irmã que me critica, mas vir alguém me acompanhar nunca veio alguém me acompanhar no médico. Eles falam, pára com isto, você quer morrer...

C. E você já falou isto pra ela, de ela vir no medico com você? 
M. Já

C. E o que que ela fala?

M. Falou que vem, mas ela tá brigada comigo, sabe. Porque meu pai falou uma coisa, ela mora em SP, ela tá aqui estes dias, meu pai falou alguma coisa que ela num gostou, ela ficou cozinhando aquilo. Ela tem muita mágoa dele, na hora que eu vejo que ela tá conversando com ele, você vê aquela coisa sufocada. Depois que eu fiz a psicoterapia eu revivi tudo aquilo, chorei outra vez, então eu acho que eu melhorei. Eu não posso mudar ele, mas eu posso mudar a mim, né?

C. E você percebe que você mudou você neste tempo?

M. A sim, porque eu carregava ele nas costas, achava tudo que era ele. Mas não é por ai não, tenho que pensar é ne mim.

(Silêncio longo)

(linhas 297-318)

C. E o que que você acha que tava acontecendo na tua vida nos momentos que você bebeu mais, ou menos.

M. Acho que faz tanto tempo que não acontece alguma coisa interessante que eu não tô preocupada. Queria que acontecesse alguma coisa pra mudar (dá ênfase). Podia mudar de casa né?

(linhas 479-483)

No primeiro extrato exploro momentos em que tenha ficado sem beber e ela diz que não sabe descrevê-los, mas diz que quando não bebe, não sente falta alguma da bebida, que se sente bem. Usa a metáfora da bola de neve para explicar seu consumo, metáfora esta que remete a algo que piora a cada dia que passa e a qual a pessoa não tem muito controle.

No segundo extrato, traz a voz da irmã, criticando-a por consumir bebidas alcoólicas. Ao trazer a voz da irmã, novamente usa o discurso da responsabilidade pessoal pela saúde. Entretanto, questiona este discurso e utiliza o discurso da importância do apoio familiar, dizendo que a irmã deveria acompanhá-la ao médico. Relata algumas desavenças familiares, posicionando-se, em contraposição à irmã, como 'Miriam que fez terapia e lida melhor com problemas familiares' e com o uso do discurso psicológico diz que se não pode mudar o pai, pode mudar a si mesma. Questiono este discurso, perguntando sobre a aplicabilidade deste em sua vida, ao que ela responde dizendo que antes fazia de tudo pelo pai, mas que agora precisa pensar mais em si. Depois desta conversa, fica um bom tempo em silêncio, parece que a pensar sobre o que foi falado. 
Como mudar, se tudo o que ela faz é solitário e se é na conversa com o outro que ela consegue se encontrar?

M. Eu acho que meus problemas começaram quando eu quis cair em mim, quando eu procurei chão pra me encontrar e não achei. Isto eu tô te falando agora porque eu fiz muita psicoterapia, senão não taria nem aqui, não daria nem pra falar.

C. De tão difícil...

M. E, eu nem chorava, vinha até aqui e descia. Não conhecia nem minha voz... Eu fiquei assim depois que eu vivi sozinha com meu pai. Meu pai e uma irmã.

(linhas 134-140)

M....olha, eu acordei 3 horas da manhã...

C. Quando?

M. Esta noite. Porque eu tinha que vir aqui.

C. Ah, e aí?

M. Eu falei o que será, né?

C. O que passou na tua cabeça?

M. Aí eu vim até cedo, mais cedo eu já tava aí.

C. O que passou na tua cabeça, Miriam, desde que eu te liguei?

M. Que ia ser amanhã, eu sou assim.

C. E você ficou pensando o que, Miriam?

M. Começou a transpirar a mão, as axilas...

C. E você ficou pensando o que a gente ia conversar?

M. Não. Era mais encontrar.

C. Encontrar?

M. Eu tenho problema com o desconhecido, meu problema é com o desconhecido, quero ter controle de tudo. Eu sempre fui assim uma pessoa que tentou controlar tudo.

C. Mas vamos pensar nesta situação também, né, Miriam, é uma situação que dá uma ansiedade, mesmo, né? Porque uma pessoa te liga, que você nunca viu na vida, e fala se você pode vir aqui me contar sua vida. Eu acho que não tem quem vai ficar tranqüilo, né? Vamos pensar, né, é uma situação que causa muita ansiedade mesmo né?

M. É. (risos)

C. A pessoa fala, nossa, vou lá, conversar com esta pessoa, o que ela vai querer saber, o que ela vai achar de mim?

M. Deu pra você tirar alguma coisinha assim, do que eu falei? Eu acho que eu tenho muita dificuldade de expor as coisas, tem gente que começa certinho, eu começo sempre de trás pra frente.

C. (risos) Cada um tem sua marca registrada, né?

M. Eu tenho uma amiga minha que ela começa a falar [...] isto não é do meu feitio.

(linhas $716-743)$

C. Você acha que esta conversa fez bem, fez mal, te fez pensar em alguma coisa, não fez...

M. É se olhar, né? Consegui olhar um pouquinho pra mim falando com você. Porque a gente fica sempre assim, né.... Porque tem outra coisa, os irmãos quando encontra com a gente, não senta e conversa "oi. Tô indo embora. Tchau", falta muito diálogo, né? De sentar, esperar. Quando o outro vai falar alguma coisa, já tá prontinho pra defender ou atacar. Tô certa?

C. É o que você falou, né. Às vezes as pessoas na correria, acaba até perdendo este costume de sentar, conversar, né. Tudo rapidinho, corrido, a gente acaba mesmo perdendo isto, e faz falta, né.

M. Faz falta.

(linhas 799-808) 
No primeiro extrato, Miriam constrói explicações para o início de seus problemas, a morte da mãe, o distanciamento dos irmãos, as novas responsabilidades que teve que assumir, os novos papéis, os novos posicionamentos. Não tinha com quem conversar, não conhecia mais sua voz. Procurou chão para se encontrar e não achou. A imagem do chão, de algo que a sustentasse, desse-Ihe firmeza, desse-Ihe segurança, aparece em contraposição com as descrições da crise de pânico e do uso problemático de álcool: descontrole, sentimento de estar sendo levada, de ter que encontrar o limite sozinha. Após a morte da mãe, passa a viver com o pai e uma irmã, mas descreve-se como vivendo sozinha. Ao falar sobre a morte da mãe, dá inicio a uma narrativa de solidão.

No segundo extrato conversamos sobre sua vontade de desistir do tratamento, já que continuava a beber. Disse que achava que devia voltar ao serviço só quando tivesse parado de beber, já que os médicos deviam estar cansados dela. Parece que se sentia posicionada por eles como 'Miriam paciente que tem que andar sozinha'. Neste contexto, falou sobre como foi sofrido para ela ir à entrevista. Dormiu mal durante a noite, chegou mais cedo, transpirou muito, teve medo do encontro. Como imaginou que seria posicionada? Ela explicou seu medo do encontro utilizando o discurso psicológico, dizendo ter ansiedade por medo do desconhecido e por ser controladora, posicionando-se como 'Miriam paciente ansiosa'. Não quis concordar com este posicionamento, e disse que o que sentiu foi normal, que qualquer outra pessoa sentiria a mesma coisa, posicionando-a como 'Miriam pessoa normal'. Ela riu e então se preocupou com minha opinião sobre ela.

No terceiro extrato, peço para que ela avalie a experiência da entrevista e ela a avalia positivamente, descrevendo-a como um momento em que pode se olhar: "consegui olhar um pouquinho pra mim falando com você". 



\section{Convites feitos a partir da conversa com Miriam}

A partir de nossa conversa, podemos construir algumas histórias sobre Miriam. Histórias estas construídas a partir dos discursos que utilizamos e dos efeitos destes na disponibilização de alguns posicionamentos. Histórias estas também construídas por posicionamentos negociados durante nossa conversa, onde vozes de outras pessoas foram incluídas nesta negociação.

Um discurso importante em nossa sociedade fala sobre os papéis sociais de gênero. Com este discurso, espera-se que mulheres adultas se casem e tenham filhos, e quando isto não ocorre, muitas mulheres descrevem-se fracassadas. Esta descrição parece ajudar a construir uma história de Miriam, descrita diversas vezes como uma pessoa que tomou decisões erradas e que por isto é solitária. Com o uso deste discurso, o posicionamento de 'filha que toma conta do pai idoso' aparece como um castigo por não ter constituído família própria.

Outro discurso muito presente nos dias atuais é o do individualismo, que gera discursos como o da responsabilidade pessoal e o do livre arbítrio. Este discurso nos diz que somos os únicos responsáveis por nossa felicidade e por nosso bem estar. Com o uso deste, desvalorizam-se as experiências de Miriam no cuidado com a família e sua expectativa de ter a família mais envolvida em sua vida. Com isto, durante seu relato, as posições que ganham maior destaque são aquelas que a constroem como uma pessoa que errou por viver pelos outros, que não soube cuidar de si mesma e que, portanto, terminou sendo solitária e infeliz. Entretanto, Castiel e Diaz (2007) nos lembram que para que uma pessoa seja responsável por algo ela deve ser capaz de prever antecipadamente o efeito de suas ações e, frente a isto, optar ou não por fazê-la. Ao cuidar da família Miriam não parecia estar escolhendo ficar sozinha ou ser infeliz, pelo contrário, parecia escolher ser uma boa filha, uma boa irmã, uma boa tia. Talvez esperasse ser reconhecida e valorizada por tudo o que fazia. Talvez esperasse ser amada por toda a família. Talvez esperasse nunca estar sozinha e nunca ser infeliz.

Mas os posicionamentos de 'Miriam boa filha', 'Miriam boa irmã', 'Miriam boa tia' são desvalorizados. Talvez ela não tenha acertado na sua previsão do futuro. E assim tornou-se a única responsável por seu presente. Estes discursos também ajudaram a construir descrições de culpa por ter deixado as coisas chegarem a este ponto, já que por ter escolhido namorados problemáticos, nunca se casou; por ter sempre vivido pela família, deixou-se assumir todas as responsabilidades com o pai. A descrição da culpa imobiliza-a e torna-a merecedora de punições (CASTIEL; DIAZ, 2007). Deixa-a sem saída. 
Em nossa conversa, o discurso médico-psiquiátrico aparece em sua vida em um momento de fragilidade e tristeza, após a morte da mãe. A posição disponibilizada por ele é a de 'paciente', ou seja, de alguém que fracassou em relação ao discurso do individualismo e não está conseguindo cuidar sozinha de sua própria vida, precisando, portanto, da ajuda de um profissional. Este discurso abre a Miriam a possibilidade de receber por aproximadamente 10 anos a ajuda de um serviço, de diferentes profissionais e de nomear experiências de sua vida, como a de querer pagar uma dívida rapidamente, como sintomas de doença psiquiátrica (ansiedade). Este mesmo discurso, aliado a outro discurso médico sobre a prevenção de riscos ligados ao consumo de bebidas alcoólicas (privar-se do consumo para evitar possíveis danos), ao discurso de gênero (mulheres adultas não devem beber todos os dias) e ao discurso da moral (é preciso domesticar impulsos hedonistas) somam-se para construir o consumo que faz de bebidas alcoólicas como algo problemático. Com isto, quando conversamos sobre seu consumo de bebidas alcoólicas, posições como 'Miriam que sabe a hora de beber', 'Miriam que não bebe se tem algo importante para fazer', 'Miriam que não bebe se tiver que dirigir' são desvalorizadas em prol de posições como "Miriam que tem culpa pelo consumo de bebidas alcoólicas', 'Miriam que não se esforça', 'Miriam que é fraca', 'Miriam que está nas mãos do inimigo'. A legitimação de alguns discursos em relação a outros refletem também os modelos utilizados por profissionais para lidar com pessoas que consomem substâncias. Vale lembrar que o discurso da abstinência é muito forte em nossa sociedade, embasando as ações de grupos de auto-ajuda, como os Alcoólicos Anônimos e de profissionais de saúde e pesquisadores, que compreendem que a abstinência é o único caminho para se evitar problemas com substâncias (BOURGOIS, 2000). Entretanto, MacRae (2009) nos lembra que as políticas de "tolerância zero" vêm fracassando ao longo do tempo, sendo necessário aprender a conviver da melhor maneira com o uso de substâncias. Este discurso, conhecido no campo da saúde como "redução de danos", vem sendo cada vez mais adotado como política, apesar de ainda não ser hegemônico e conviver com outros discursos, como o da "tolerância zero". De acordo com a redução de danos, os profissionais precisam conhecer as estratégias de autocuidado já utilizadas pelas pessoas que consomem substâncias e utilizá-las para a prevenção de efeitos indesejáveis (MACRAE, 2009). Com este discurso, valorizamos os posicionamentos de Miriam que se referem a não dirigir quando bebe, ou a beber apenas depois do trabalho ou quando não tem nada de importante para fazer.

Quando pensa em mudança, Miriam lembra-se novamente do discurso da responsabilidade pessoal, trazido para a conversa nas vozes de familiares e médicos, e culpa-se por estar prejudicando sua saúde, cobrando-se de ter que encontrar respostas dentro de si e de ter que encontrar a felicidade sozinha. Nas palavras de Castiel e Diaz (2007, p.46) "o fato de estas pessoas se exporem aos chamados riscos comportamentais 
já as coloca candidatas à pecha de 'irresponsáveis' - passíveis de receberem manifestações de crítica em termos morais por sua falta de autocuidado". Neste caso, parece que o discurso da responsabilidade pessoal culpabiliza-a e afasta-a das pessoas, inclusive dos serviços de saúde. Miriam nos diz que voltará ao tratamento apenas quando parar de beber, já que promete um tanto de coisa e dá tudo errado. Conclui dizendo que falta esforço pessoal. O discurso psicológico da motivação interna também ajudará a descrever-se como alguém que está em dívida com o tratamento, já que não consegue atingir os objetivos propostos neste. Segundo Fontanella (2000), as pessoas intrinsecamente motivadas ao tratamento teriam a percepção clara do problema da dependência, tendo mais chances de sucesso no tratamento. O autor ainda coloca que o leva uma pessoa a ser mais ou menos motivada internamente relaciona-se a fatores complexos da dinâmica psíquica, incluindo os benefícios primários ou secundários da dependência. Um dos efeitos deste discurso pode ser a responsabilização de Miriam por estar se beneficiando da dependência e por não se prevenir, em uma atitude, quase religiosa, de respeito e temor aos problemas que podem ser causados pela dependência de bebidas alcoólicas. Usa também o discurso bélico, relatando que tem que travar uma guerra contra seu desejo de beber e, com isto, posiciona-se como 'Miriam que perdeu a batalha' e 'Miriam que está nas mãos do inimigo'. Para MacRae (2009), mesmo deixando de ser controladas unicamente pela religião e passando para as mãos da medicina, as drogas continuaram a ser encaradas como potenciais causadoras de problema, agora não mais demoníacas, mas causadoras de dependência. Com isto ele observa que permanece "um processo de atribuição a essas substâncias de certos poderes de enfeitiçamento quase impossíveis de resistir pelo indivíduo" (p.01). Com este discurso, Miriam nos coloca que este é um inimigo que tem que aceitar, que não consegue lutar contra.

Busca ajuda no discurso da importância do apoio familiar para questionar o discurso da responsabilidade pessoal pela saúde e cobrar dos irmãos maior envolvimento em seu tratamento e em sua vida. Entretanto, este discurso parece não encontrar respaldo em seus relacionamentos para ser legitimado. O discurso da responsabilidade pessoal parece caminhar junto ao discurso da autonomia, discurso este super valorizado na saúde pública atual. Camargo-Borges, Mishima e McNamee (2009) problematizam este discurso, afirmando que este considera que a pessoa racionalmente faz julgamentos e avaliações, sendo responsabilidade dela as conseqüências destas apreciações. As autoras colocam que um dos efeitos deste discurso é simplificar o entendimento da questão, deixando de analisar outros fatores que influenciam naquele evento, responsabilizando apenas o indivíduo por suas escolhas. De posse deste discurso, o modo como Miriam consome bebidas é um problema apenas dela. Desconsidera-se a responsabilidade das pessoas próximas a ela na manutenção de seu modo de vida e dos diversos atores que disponibilizam discursos que constroem este consumo como 
problema. Ainda segundo o discurso da autonomia, McNamee (SOUZA et al, 2009) ${ }^{7}$ nos pergunta: "O que há de errado em dependermos uns dos outros?" Com isto, coloca que as pessoas podem ser estimuladas a cuidarem de si, mas também a entenderem que não há problema em buscarem ajuda nos outros quando precisarem. Sugere que trocando o "autocuidado" pelo "cuidado relacional", talvez patologizaríamos e estigmatizaríamos menos, já que a responsabilidade não seria apenas do outro, mas nossa também. 0 discurso do autocuidado é construído de modo que não implica outras pessoas no cuidado, apenas o indivíduo. Com isto convida à culpabilizaçao do outro. Entretanto, o discurso da responsabilidade pessoal parece mais hegemônico atualmente e, com isto, Miriam é posicionada como 'Miriam que não tem força de vontade' e 'Miriam que tem que mudar sozinha'. Não encontra apoio. Busca também ajuda no discurso do amor romântico, e espera que alguém apareça para lhe salvar e ajudar a mudar sua vida. Entretanto, este discurso, por colocar o amor como vocação da mulher e privilegiar as relações íntimas (NEVES, 2007), parece só aumentar seu sentimento de solidão e de fracasso pessoal.

Com isto, a história de Miriam construída em nossa conversa, é a de uma mulher solitária, sofrida, entediada e a mercê de seu destino. É a de uma pessoa sem sonhos, sem paixões e emoções, portanto, sem motivação para fazer mudanças em sua vida. 0 modo como se constrói, acompanhado por um tom de voz resignado e descomprometido, dificulta a abertura para novas descrições, já que as posições que a fortaleceriam, são colocadas à margem da narrativa.

A história que construímos sobre Miriam pode ilustrar o que White e Epston (1990) chamam de narrativa saturada pelo problema. Esta é uma descrição é muito utilizada no campo da terapia narrativa e trazida aqui para compreendermos um pouco mais sobre a história de Miriam construída em nossa conversa. Nesta perspectiva, compreende-se que as histórias constroem a experiência vivida, os diferentes posicionamentos e possibilidades futuras. Entretanto, algumas histórias parecem dominar as narrativas. Em alguns casos, estas histórias contam sobre uma vida que é dominada pelo problema. São chamadas "narrativas saturadas pelo problema". Estas narrativas limitam as possibilidades da pessoa ser e agir no mundo. No caso de Mirim, a narrativa saturada pelo problema faz com que a 'Miriam que tem vontade de mudar' seja deixada de lado em favor de um posicionamento antigo - 'Miriam que não consegue deixar de pensar na família'. Em outros momentos, a descrição de uma mulher que já teve paixões e que já venceu as dificuldades financeiras, é abafada pela descrição de uma mulher que não se apaixona mais e que está entediada a espera que algo Ihe aconteça.

7 SOUZA, L.V; SANTOS, M.A.; CORRADI-WEBSTER, C.M.; GUANAES, C. MOSCHETA, M.S. Social Construction and Health: An interview with Sheila McNamee. Revista Colombiana de Psicología, 2009. (artigo encaminhado para apreciação). 
O desafio aqui é: como trazer para o centro da conversa estas posições que ficaram à margem e assim construir diferentes descrições? Quais outros discursos poderiam ser usados para valorizar posicionamentos que a construiria como uma mulher forte, com recursos, com possibilidade de fazer mudanças? Será que nossas práticas terapêuticas não vêm auxiliando a marginalizar estes posicionamentos? De acordo com Avdi (2005), a identidade patológica é um processo recursivo, que envolve o afunilamento dos repertórios de narrativas disponíveis e a dominação de significados saturados pelo problema, que são tipicamente associados ao discurso médico. 0 tratamento mais utilizado no campo de álcool e outras drogas é o focado no problema do consumo. Desta forma, primeiramente é preciso conhecer bem os sintomas, a história clínica, a história familiar e, com isto, listar os problemas encontrados e fazer um diagnóstico. O seguimento muitas vezes se dá registrando o consumo da última semana até o momento da consulta, as situações que favoreceram este consumo e as estratégias que poderiam ser utilizadas para lidar com estas situações. O consumo de álcool é o foco, é o tema central da consulta. Esta estratégia funciona com muitos, mas no caso de Miriam, parece não ter funcionado. Seus posicionamentos frente ao tratamento e frente ao consumo de álcool é o de alguém que perdeu a batalha.

Com estas questões em mente, a conversa com Miriam nos convida a refletir sobre o tratamento. Proponho a reflexão em duas perspectivas:

1.) Função e limites do tratamento: nesta perspectiva, ela nos convida a olhar para o tratamento de modo mais amplo e integrado ao discurso da medicalização. Apesar dos diagnósticos de síndrome de pânico e de dependência de álcool legitimarem os quase 10 anos de tratamento em ambulatório de psiquiatria e serviço de psicoterapia, Miriam constrói, em sua narrativa, o problema que Ihe aflige: solidão. Com isto, parece que o pedido que faz aos médicos pode ser descrito como de companhia. Neste percurso, encontra profissionais que aceitam seu pedido, seguram-na pelas mãos e caminham junto a ela por determinado tempo. Mas também encontra profissionais que têm como objetivo ajudá-la a diminuir os sintomas de seus diagnósticos e que entendem que ela está há muito tempo em tratamento e que precisa andar sozinha. É importante lembrar que estamos nos referindo a um serviço público, referência para casos mais graves e com uma fila de espera grande. Dentro deste contexto, compreendemos a preocupação do médico para que Miriam procurasse outros caminhos. Entretanto, aqui se faz a questão: em uma sociedade medicalizada, que transforma aspectos da vida cotidiana em objeto da medicina a fim de garantir conformidade às normas sociais (TESSER, 2006), onde a cada dia que se passa criamos novos diagnósticos e tecnologias, e apresentamos imensa literatura científica e leiga que constrói emoções, comportamentos e pensamentos como diagnósticos médicos, oferecendo como possibilidade de mudança a procura por um serviço de saúde, quais outros recursos, quais outros discursos, estão 
disponíveis para uma mulher de 54 anos, que não se casou ou teve filhos, que sempre viveu para cuidar da família, que se sente sozinha, que se sente entediada? Nesta história, percebemos a dificuldade de pensar em recursos fora do tratamento, tanto por parte da entrevistada como da entrevistadora. Durante a entrevista, mobilizada pelo pedido por companhia, por espaços de escuta, sugiro a busca por psicoterapia. Não seria a hora de nós, profissionais e pesquisadores de saúde, entendermos os limites de nosso campo de ação e começarmos a valorizar outras práticas, outros discursos? Se profissionais e pesquisadores em saúde ajudarem a legitimar outros discursos, que falem sobre jeitos de viver ao invés de diagnósticos, poderíamos fortalecer outros recursos sociais como potenciais espaços para mudança? Encontraríamos a Miriam envolvida em outras atividades e grupos, consumindo bebidas alcoólicas em contextos não considerados problemáticos, ao invés de tê-la há 10 anos em um ambulatório de psiquiatria, sendo posicionada como uma paciente resistente, que não se desenvolve e que precisa andar sozinha? Ou será que o discurso da medicalização é tão forte em nosso mundo atual de modo que nossa sociedade está organizada em volta dele, não havendo outros espaços de escuta? Para McNamee (2002), o discurso do individualismo e da medicalização vem destruindo nossos vínculos com a comunidade, com nossas tradições e rituais. Há 30 anos Illich (1975) já tecia críticas e chamava a atenção para o que nomeou "iatrogênese da medicina institucionalizada" (iatrogenia - termo utilizado em medicina para se referir à produção de danos à saúde devido à ação médica), destacando três aspectos: 1) iatrogênese clínica, referindo-se aos danos causados pelo diagnóstico ou terapêutica médicas; 2) iatrogênese social, referindo-se à medicina causando danos sociais, impactando sobre o indivíduo e seu grupo social, gerando perda de autonomia e de controle do meio, construindo o doente como passivo e dependente do médico; 3 ) iatrogênese cultural, referindo-se à destruição dos recursos culturais para lidar com enfermidades, problemas, doenças e morte (TESSER, 2006). Na história de Miriam, o diagnóstico passou a fazer parte de sua identidade e ela passou a ser posicionada, por familiares, amigos e por mim, como alguém que precisa de terapia e tratamento.

2.) Estratégias para o tratamento - nesta perspectiva a conversa com Miriam nos convida a olhar para o que acontece dentro do tratamento e para como, enquanto profissionais de saúde, ajudamos a construir histórias de vida com nossos discursos e com nossas práticas. O tratamento de sucesso foi o que a ajudou a construir-se como a pessoa mais maravilhosa do mundo. Este tratamento é descrito com foco no relacionamento paciente e terapeuta. É importante lembrar que este tratamento teve como molde a psicoterapia de orientação psicanalítica, foi realizado com peridiocidade semanal durante um ano, tendo como ponto de partida o olhar para a pessoa de modo integral, e como objetivo o desenvolvimento de recursos pessoais para o enfrentamento cotidiano. Desta forma, é descrito por ela como um tratamento que a fez crescer, no qual 
ela saiu de modo diferente do que entrou, apontando os indicadores de sucesso o fato do médico ter acertado sua medicação, ter se envolvido a ponto de chorar com ela e ter ajudado-a a descrever-se como alguém que tem a auto-estima elevada. Esta experiência aparece em contraposição à outra, que a ajudou a construir-se como uma pessoa que passa pela vida dormindo, como alguém que não se esforça, como alguém que está em dívida com o tratamento, como alguém resistente, como alguém que não adere às atividades e aos objetivos propostos. Vale lembrar que o tratamento em questão tem como molde o tratamento psiquiátrico ambulatorial, dentro de uma unidade de farmacodependências, tendo como ponto de partida o diagnóstico psiquiátrico e como objetivo o controle da sintomatologia. Para isto, seguindo orientações da literatura científica no campo de álcool e outras drogas, adota estratégias motivacionais, composta por técnicas e exercícios que visam sensibilizar o paciente para as conseqüências negativas de seu comportamento e, com isto, mobilizá-lo para envolver-se em mudanças comportamentais. Este tratamento foi o considerado por ela como algo que the trouxe a sensação de fracasso, de não se esforçar, de estar em dívida. Como indicadores para o fracasso deste tratamento ela aponta não conseguir cumprir com os objetivos propostos, não compreender e não realizar as atividades sugeridas e faltar às consultas. Esta reflexão não visa propor que o tratamento de orientação psicanalítico seja melhor do que o tratamento psiquiátrico ambulatorial com foco na motivação para mudança. Uma das mulheres entrevistadas, cuja entrevista não foi selecionada para compor o corpus deste estudo, recebeu o tratamento psiquiátrico ambulatorial e relatou ter sido muito beneficiada com este. A literatura também relata diversas experiências nas quais o uso de estratégias motivacionais é potente e transformador (MILLER; ROLLNICK, 2001). Com esta reflexão gostaria de problematizar a supremacia de determinadas teorias e técnicas dentro do campo de estudo de álcool e outras drogas, que por serem legitimadas em congressos científicos da área e em inúmeros artigos internacionais, aparecem como sendo a única opção para a abordagem de pessoas que consomem bebidas alcoólicas de modo considerado problemático. Além disto, na tentativa de sermos pragmáticos e diretivos, muitas vezes, passamos a idéia para o público que participa de congressos e capacitações na área, de que é preciso apenas seguir algumas técnicas. Esquecemos-nos de falar da relação. Com isto, munidos por diagnósticos, protocolos e estratégias de trabalho, estamos nos se esquecendo, nas palavras de Ayres (2004, p.585), que "há em toda ação terapêutica, em qualquer escala que se as pense, um autêntico encontro entre sujeitos, no qual inalienáveis interesses de compreensão e simultânea construção do si mesmo e do outro estarão presentes". E neste encontro de sujeitos, a valise da tecnologia leve (MERHY, 2000), aquela tecnologia produzida na relação profissional \& paciente, através da escuta, do vínculo e da construção conjunta das necessidades de saúde deve ser mais valorizada e utilizada. A entrevista motivacional, assim como outras 
estratégias utilizadas na área (dentre elas: entrevista de anamnese, uso de questionários, treinamento de habilidades sociais, intervenções breves, prevenção de recaídas, redução de danos, terapia focada na solução) podem trazer interessantes ferramentas para o trabalho terapêutico, entretanto, não devemos deixar que estas tomem o lugar da relação. Ao estudar o discurso da entrevista motivacional, algo que às vezes passa despercebido, é que os autores chamam a atenção para características do terapeuta, colocando que estas são mais importantes para um tratamento efetivo do que a escola de pensamento a que estão afiliados (MILLER; ROLLNICK, 2001). Estes autores falam sobre empatia, acolhimento e autenticidade. Entretanto, o que mais se divulga sobre a entrevista motivacional são avaliações e exercícios. São técnicas. Não podemos deixar que nossas técnicas e procedimentos fiquem entre nós e nossos clientes, impedindo-nos de ser responsivos (SOUZA et al, 2009; AYRES, 2004). Um estudo realizado com mulheres que fizeram tratamento para o consumo de bebidas alcoólicas relata que elas deram grande importância para a postura do conselheiro, valorizando aqueles que mostravam ter preocupação com elas, ouvindo-as e oferecendo suporte. Destacaram como características importantes dos conselheiros a dignidade, o respeito e a preocupação genuína. Os conselheiros descritos como ruins eram aqueles que ouviam pouco, que tinham pouco tempo a oferecer, que mostravam pouco respeito ou compaixão por elas e que tinham inabilidade de individualizar o plano de tratamento. O estudo narra que a experiência de ser ouvida por um "bom conselheiro" foi associada a ficar no tratamento e até a atingir a sobriedade, enquanto a experiência de ser atendida por um "mal conselheiro" foi associada com o abandono do tratamento.

O pedido construído por Miriam durante a entrevista não foi o de parar de beber, foi sair da solidão, mudar sua vida. Como estamos ajudando nossos pacientes na construção e execução de seus projetos de felicidade (AYRES, 2004)? Trago o desafio proposto por Ayres para o campo de estudos em álcool e outras drogas: Como planejarmos um tratamento que busque a totalidade existencial, permitindo dar significados e sentidos não apenas à saúde, mas ao projeto de vida? Quando nossas técnicas e recursos passam a ser protocolos de atendimento, perdemos a oportunidade de explorar com o paciente outras histórias, outras descrições de si, outros posicionamentos, outras relações que poderiam gerar cuidado e felicidade. Se mantivermos, como regra, o foco de nossas consultas no uso de álcool, perderemos a oportunidade de co-conhecer/co-construir o projeto de vida e de felicidade de nosso interlocutor, fortalecendo o vínculo e dando sentido para o manejo da saúde.

Ainda sobre o tratamento, Miriam nos diz ter tido 'insights'. Hoje ela sabe qual a origem de seu problema: ter se sentido sozinha no momento em que mais precisou de ajuda. Entretanto, conhecer a origem de seu problema não parece ter ajudado-a a buscar soluções. Nossas práticas psicoterápicas são altamente influenciadas pelos 
discursos médico e psicológico, que embora priorizem coisas diferentes, têm poder explicativo grande (AVDI, 2005). O discurso médico localiza o agenciamento dentro dos sintomas, que são representados como manifestações da doença e abstraídos da vida e do contexto do indivíduo. Parte do discurso psicológico coloca o terapeuta como um detetive, que deve buscar a verdade escondida por trás de relatos, comportamentos e sintomas, acreditando que não há nada aleatório na vida psíquica ou interpessoal. É preciso chegar à verdade, falar sobre ela, revivê-la, para poder ressignificá-la e, assim, obter a cura. Com isto, ambos convidam o paciente a falar sobre o problema.

De acordo com o entendimento de linguagem utilizado neste estudo, linguagem como construtora da realidade, ao conversarmos sobre o problema, estamos ajudando a construí-lo. de Shazer (1994) conversou com terapeutas que utilizaram 45 minutos da sessão explorando, junto aos pacientes, os problemas que Ihes afligiam. Ao final da sessão, os terapeutas relatavam sentirem-se desgastados com a conversa e preocupados com o prognóstico do caso. Conversou também com terapeutas que utilizaram 45 minutos da sessão conversando sobre as expectativas positivas que os pacientes tinham com o tratamento, sobre recursos que já vinham utilizando para conquistarem seus desejos e sobre como seria suas vidas caso um milagre acontecesse e eles alcançassem o que esperavam. Ao final da sessão, os terapeutas relatavam sentirem-se animados com o atendimento e esperançosos com o prognóstico. A questão levantada por de Shazer foi: se os terapeutas se sentiram assim, como se sentiam os pacientes?

Desta forma, as mudanças são vistas como acontecendo dentro da linguagem. Sobre o que nós falamos e como nós falamos sobre algo é o que faz diferença (DE SHAZER, 1994). Assim, nomear o problema de dependência de álcool, ou de transtorno de ansiedade, ou de solidão, levam a diferentes caminhos. Assim como, não nomear problemas e sim nomear sonhos, também leva a diferentes caminhos.

Compreendemos que em um encontro terapêutico, cliente e terapeuta estão juntos construindo uma história, que pode tanto ampliar como restringir as possibilidades existenciais. Se aceitarmos o convite de Grandesso (2000) e assumirmos, enquanto terapeutas, nossa responsabilidade na construção destas narrativas ao invés de supor que há uma verdade por trás da história do cliente, podemos nos perguntar qual narrativa queremos ajudar a construir.

A fim de mudar perspectivas e abrir outras possibilidades de construção de sentidos, podemos também descentralizar o discurso dominante do diagnóstico, apresentando outras formas de contar a história ou de fazer perguntas, de modo que subvertam este discurso.

Miriam recebeu dois diagnósticos psiquiátricos: primeiramente de um transtorno de ansiedade e depois de um transtorno de dependência de álcool. O discurso do diagnóstico está inserido dentro de um discurso maior, o discurso individualista de déficit 
(MCNAMEE, 2002). Individualista, pois considera que o problema esteja dentro do indivíduo, de sua mente individual. De déficit, pois olha para o que está errado, para o que está faltando. Tem foco no problema. O discurso do diagnóstico psiquiátrico também representa uma situação onde o discurso médico está poderosamente implicado na construção da identidade pessoal (AVID, 2005). Miriam nos relata que se sentiu mal quando a mãe morreu e percebeu-se só. Procurou um serviço de saúde e recebeu um diagnóstico. E se naquele momento, sua família tivesse se unido para lidar com as questões surgidas após a morte de sua mãe? E se ela tivesse deixado a família, deixado o pai e a casa sob cuidado dos irmãos? Teria ela recebido tais diagnósticos? Este exercício busca nos lembrar que a Miriam não é uma pessoa ansiosa ou uma pessoa dependente de álcool. Estes diagnósticos não estão dentro dela. Foram construídos naquela situação de sua vida, dentro de um contexto discursivo maior. Entretanto, após recebê-los, Miriam utiliza estes diagnósticos diversas vezes para se descrever e para justificar seus comportamentos. Passam a fazer parte de sua identidade e de sua história. Ela nos conta que é ansiosa e é dependente. Nesta situação parece que o diagnóstico ajudou a engessar posicionamentos e a construir narrativas saturadas pelo problema. Além disto, com estes fortes discursos presentes em nossa sociedade, compreendemos também porque Miriam não consegue o apoio da família. Para o discurso do diagnóstico psiquiátrico, se a pessoa tem algum problema, é ela quem deve se cuidar, é ela quem deve se tratar. Este discurso impossibilita outras descrições e reifica a doença mental. Muitos profissionais já se engajam em uma relação em busca de critérios estabelecidos em classificações diagnósticas e, ao fazer um diagnóstico, reduz a pessoa a ele. A partir daí, tudo o que for dito ou feito pelo paciente será interpretado como algum sinal ou sintoma deste diagnóstico. Nas palavras de Gergen e Kaye (1998; p.207) "independente da complexidade, sofisticação ou valor do relato do cliente, ele será inevitavelmente substituído por uma narrativa criada antes de sua entrada na terapia, e sobre cujos contornos ele não tem nenhum controle".

Um discurso alternativo a este é o do engajamento relacional (McNamee, 2002). Ele nos convida a prestar atenção ao "que fazemos juntos". Nossa realidade não é dada, assim como nossa personalidade também não é algo que temos dentro de nós. São construções relacionais e contextuais. Desta forma, se Miriam descreve-se a partir dos diagnósticos, é porque tem estas posições sustentadas por discursos e pelos seus relacionamentos. As vozes dos profissionais afirmam seu diagnóstico; as vozes da família afirmam que por ser doente, tem que se tratar sozinha; eu afirmo que por se sentir só, seria beneficiada com a terapia; e assim por diante. Estamos inundados por discursos que individualizam e que prendem Miriam aos seus diagnósticos e ao seu tratamento.

$\mathrm{Na}$ conversa com Miriam, não valorizei os posicionamentos que estavam marginalizados. Dialoguei com a 'Miriam que não conseguiu parar de beber' e não com a 
'Miriam que exerce controle sobre o consumo'. Aceitei seu convite de construir uma narrativa saturada pelo problema. Com esta reflexão, destaco que também tive responsabilidade pela construção desta história. Estar atento ao que fazemos juntos é considerarmos que, nos relacionamentos, também somos responsáveis pela construção das histórias. Estar atentos ao que fazemos juntos é refletir sobre como auxiliamos nestas construções e com isto, buscarmos novas formas de nos relacionar, a fim de mantermos o diálogo aberto e construirmos uma relação de ajuda. Estar atentos ao que fazemos juntos é não trazer narrativas prontas para a conversa (diagnósticos, teorias, experiências), é não rotular a pessoa com um diagnóstico e compreendê-la apenas a partir deste, é não colocar no outro toda a responsabilidade pela mudança.

Para finalizar, a conversa com Miriam também nos convida a pensar questões éticas da pesquisa. Ao convidarmos alguém para participar de uma entrevista, estamos interferindo em sua vida, criando expectativas, sonhos e medos. Miriam nos lembra que nenhuma pesquisa é inócua e que nossa responsabilidade enquanto pesquisadores é grande. Com isto, voltamos às questões levantadas por pesquisadores construcionistas sociais sobre a ética em pesquisa (SPINK, 2004; HOSKING; MCNAMEE, 2009). Minha colaboradora dorme mal à noite na expectativa da entrevista. Acorda cedo, vem até meu trabalho e conversa comigo por duas horas, contando sobre sua vida. Permite que eu grave a conversa e que a use para minha pesquisa. Meu compromisso ético é grande. Do mesmo modo como ela passou a noite anterior pensando na entrevista (e provavelmente dias, desde que fiz o primeiro contato telefônico), ela também passará outros dias pensando em nossa conversa. Frente a isto, autores construcionistas nos convidam a borrar as fronteiras entre pesquisa e intervenção, a pensar que o momento de pesquisa é também um momento de intervenção, de construção de significados e de realidades. Com isto, fica a pergunta: que realidade queremos construir enquanto pesquisadores (ex. no contato com os colaboradores, em nossas publicações)? 



\section{Convite para construir outra versão para a história de Miriam}

Miriam,

Em nossa conversa, pedi que você me contasse a história de sua vida. E você me contou que desde criança sempre se preocupou muito com sua família, mostrando que para você sua felicidade sempre andou junto com o desejo de ver sua família feliz. Sabia que a felicidade de sua mãe seria ter a casa reformada e, desde cedo, você se doou para a realização deste sonho. $E$ isto foi algo que você conseguiu e mesmo que ela não possa ter estado presente para compartilhar esta vitória, tenho certeza de que a reforma que você conseguiu fazer de sua casa foi oferecida à memória dela. Você também sempre se mostrou gentil com seus irmãos, quando criança, dividindo as roupas com eles e, depois de adulta, ajudando-os a casar e a criar os filhos. Esta mesma generosidade você mostrou quando resolveu cuidar de seu pai e, mesmo tendo recordações ruins de sua infância com ele, você passou por cima de tudo, mostrou quão grande é sua generosidade e dispôs-se a ajudá-lo no cuidado com a alimentação, vestuário e até, a pagar sua promessa dominical. Só uma pessoa com muito amor dentro de si e com muita sensibilidade para a necessidade do outro, poderia doar-se como você vem doando-se. Deve ter aprendido com sua mãe a ser generosa assim, aceitando em casa e chamando de irmã, a filha que seu pai teve com outra mulher e sendo importante na vida dela, já que ficou ao seu lado quando esta teve que enfrentar o pai dizendo que estava grávida.

Ler nossa conversa me leva a pensar também em responsabilidade. Esta é outra característica que anda junto de você desde criança. Quando tinha um dinheiro para comprar roupas, comprava para você e para os irmãos, procurando contribuir com sua parte para as necessidades e bem estar de sua família. Desde que começou a trabalhar, saiu-se muito bem em seus empregos, e sempre batalhou por uma boa colocação, por um emprego que lhe oferecesse estabilidade. Teve sucesso nisto, conseguindo passar em um concurso público, garantindo assim um emprego estável. Mostra sua responsabilidade quando me conta também que sempre que assume uma dívida, preocupa-se em pagá-la rapidamente. Quando sua mãe faleceu, mesmo sentindo-se triste e sozinha, encontrou forças para correr atrás do inventário e de todos os documentos e papéis que foram necessários. Sua responsabilidade também é demonstrada quando você me conta que evita situações em que após beber, terá que dirigir e, nestas ocasiões, prefere não beber. Conhece os riscos desta situação e faz de tudo para evitá-los.

Percebo em sua história que você também é uma pessoa romântica. Por ser assim tão romântica, acaba acreditando em príncipe encantado. E aí, quando vê defeitos nos namorados que teve, acha que eles eram todos problemáticos. Entretanto Miriam, me 
parece que eram apenas homens normais, com seus defeitos e qualidades. Assim também são teus irmãos, sobrinhos, pai, médicos, eu e até você mesma, pessoas com defeitos e qualidades. Sabe Miriam, homens perfeitos e famílias perfeitas existem apenas em alguns filmes e romances.

Você me parece uma mulher sonhadora e uma mulher capaz de realizar os sonhos. Fiquei impressionada quando você me disse que conseguiu comprar uma casa para você. Pense no que você teve que fazer para realizar este sonho. Tenho certeza que não foi fácil e que não aconteceu de uma hora para outra. Mas tendo o sonho como pano de fundo, você utilizou sua responsabilidade, organização e trabalho para conseguir realizá-lo. Ah, Miriam, tenho certeza que você deve ter mil histórias para contar sobre esta vitória que foi a compra de sua casa. Isto me leva a pensar, que você é o tipo de pessoa que consegue vencer os desafios e realizar os sonhos. Qual será seu próximo desafio? Qual teu próximo sonho?

Esta conversa sobre sonhos e desafios, me fez lembrar também quando você tirou carta para dirigir. São poucas as mulheres que com 38 anos se aventuram a aprender a dirigir. E mais uma vez você conseguiu. E pelo jeito deve ser uma ótima motorista, já que fica super concentrada quando dirige.

Outro aspecto que me chama a atenção ao ler nossa conversa é sobre sua curiosidade. Você me parece uma pessoa bem curiosa. Só uma pessoa curiosa gosta tanto de fazer psicoterapia como você. Você tem aquela curiosidade de se conhecer mais, de explorar e de querer entender como as coisas acontecem. Tem pessoas que passam pela vida dormindo, mas você não é uma delas. Você é curiosa e você é capaz de realizar sonhos. Entretanto, há muito tempo vem usando sua curiosidade para conhecerse fazendo psicoterapia e me diz que está cansada disto. A psicoterapia é um modo de nos conhecermos, mas não é o único. Podemos também nos conhecer ao fazermos coisas diferentes, nos envolvermos com outras pessoas, explorarmos mundos que estão fora da gente.

Com toda correria que sempre foi sua vida, me parece também que você não gosta muito do tédio. Gosta de sentir emoções fortes, gosta de se apaixonar (por pessoas, por sonhos, por idéias). Novamente faço um desafio: pense sobre os sonhos que você tem, sobre coisas que gostaria de fazer, sobre coisas que gostaria de ver, e invista nisto. Você é uma mulher do século 21: trabalha, tem seu dinheiro, tem suas vontades, tem seus sonhos.

Continue cuidando sempre bem de você. Ou melhor, cuide ainda melhor de você! Use sua criatividade e força, e cuide de seus sonhos!

Sua vida é um exemplo de generosidade, responsabilidade e esforço para a realização dos sonhos. 
Agradeço por ter compartilhado um pouco de sua vida comigo e por ter me mostrado que mulher valorosa você é. Tenho certeza de que o mundo seria melhor, se tivéssemos mais pessoas como você.

Clarissa 

Capítulo 6

Histórias de Ana 

"Yes, We SUFFer PAIN, We BECOME ILL, WE DIE. BUT WE ALSO HOPE, LAUGH, CELEBRATE; WE KNOW THE JOY OF CARING FOR ONE ANOTHER; OFTEN WE ARE HEALED AND WE RECOVER BY MANY MEANS. WE DO NOT HAVE TO PURSUE THE FLATTENING OUT OF HUMAN EXPERIENCE." 



\section{Diferentes formas de narrar a história de Ana}

Ana, 62 anos, nascida no interior de São Paulo, na zona rural. Cabelos curtos e avermelhados, voz firme e controladora, vestido estilo indiano. Poderia ser a personagem de um filme sobre a luta armada brasileira na década de 70, ou uma intelectual feminista falando sobre gênero e poder, mas estava ali por ser selecionada como uma ex-paciente de um ambulatório de tratamento para alcoolistas e foi convidada a contar sua história de vida.

A. Depois você deixa eu ouvir só um pedacinho...

C. Lógico... Então, pra gente começar nossa conversa. Então, eu tava te falando que os objetivos é a gente entender como é o relacionamento da mulher com bebida alcoólica e como o relacionamento vai mudando no decorrer da vida da mulher. Então, Ana eu queria que você me contasse um pouquinho da tua vida.

A. Em que sentido você diz, do todo ou só da parte de...

C. Da bebida?

A. Da bebida.

C. Como você prefere?

A. Se for pra contar tudo, aí, já viu, então nós vamos ficar aqui o dia todo...

(Linhas 01-10)

Neste extrato apresento os objetivos da pesquisa e posiciono-a como 'Ana que tem relacionamento com bebida alcoólica', pedindo para que ela me conte um pouco sobre sua vida. Ana então se posiciona como 'Ana que tem outras posições', perguntandome se gostaria de ouvir sobre toda a sua vida ou apenas sobre seu consumo de bebidas alcoóllicas. Nesta fala, ela dá indícios de como se construirá durante a entrevista, como uma mulher que tem uma história de vida rica e complexa, tendo passado por dificuldades e lutas que vão além do consumo de bebidas alcoólica. Com isto, também damos indícios de como o assunto "bebidas alcoólicas" seria abordado durante a entrevista: com seu silêncio e minhas tentativas recorrentes de abordar o tema.

Sua mãe separou-se do pai quando Ana era recém-nascida e contou-Ihe que o pai, jogador inveterado, havia apostado a filha no carteado e perdido. Com medo de ter que entregar a filha para um casal de estrangeiros, a mãe fugiu com ela. 
C. Você não chegou a conversar com ele, então?

A. Não, eu não tinha contato com ele. E minha avó, por sua vez ruim, não deixava. Então às vezes um amigo que tava perto dele me chamava pra dar uma balinha. Alguma coisa, mas nunca passou de balinha. Então eu não conheci ele. Mas a história que eu conheço, eu sei uma versão, não sei a outra. Que ele era jogador de baralho, e que ele perdia tudo. Numa ocasião ele perdeu no jogo, diz que perdeu o enxoval da minha mãe, e no final tem uma história que ele jogou a mim numa banca.

C. Logo que você nasceu?

A. Eu era pequena, né, porque foi depois daí que minha mãe fugiu e foi pra casa da minha avó. Porque diz que ele jogou a mim numa mesa de jogo e foi um casal alemão que ganhou a aposta e eles não tinham filhos. E eles queriam. Só que um irmão do meu pai ficou sabendo disto, correu na casa do meu avô, porque minha mãe diz que morava na casa do meu avô e minha avó e tinha este irmão dele, o nome dele era Oscar e ele ficou sabendo desta história, porque a conversa logo se espalhou, então ele correu na casa do pai para avisar minha mãe do que tinha acontecido. Inclusive diz que meu avô ajudou a minha mãe a fugir comigo.

C. O teu avô pai dele?

A. Pai dele.

C. Ele também considerava que isto não era certo?

A. Não era certo, e outra, ele não concordava porque ele também já tinha explorado muito o pai e o pai tinha dado muito dinheiro e ele não arrumava a vida dele, ia só pra casa do jogo, parece também que houve muita desavença entre eles, mas as desavenças do lado de lá eu não lembro, porque eu devia estar entre os 5 ou 6 meses ou do dia que nasci até o 6 meses e, porque o que eu sei é que se separaram quando eu tava com 6 meses.

(Linhas 50-73)

Neste extrato Ana inicia a construção de sua história de vida, que como um bom drama, tem início com uma situação forte e chocante: o pai apostou-a no jogo quando era recém nascida. Os posicionamentos que aparecem aqui são: 'Ana que não conheceu o pai', 'Ana que foi usada como moeda pelo pai no carteado', 'Ana que foi protegida pela família'. Este relato ajudará a construí-la como uma mulher que enfrentou muitas dificuldades, desde o seu nascimento.

Foi então criada pela mãe, no sítio da avó e dos tios. A família trabalhava na roça dia e noite e aos finais de semana, embalados pela cachaça, discutiam o trabalho, entravam em conflitos, e distribuíam vassouradas e porradas. Para que ela não assistisse as brigas, sua avó colocava-a para dormir, ninando-a com um pouco de pinga com açúcar.

C. Como você prefere?

A. Se for pra contar tudo, aí, já viu, então nós vamos ficar aqui o dia todo... O problema é o seguinte: $\mathrm{Eu}$, que eu me lembro bem eu tinha os meus 4/5 anos, então tinha, quase as pessoas todas da família bebiam, meus tios bebiam, a gente morava num sítio, meus tios, minhas tias, minha avó, minha mãe, porque o meu pai e minha mãe se separaram eu tinha 6 meses de idade e ai eu passei a viver com minha avó e com minha mãe. E lá era assim, eram muitas brigas, de pancadaria mesmo, de um machucar outro, de tirar 
sangue do outro, era violência e quando eu me apavorava muito, o que eles faziam? Eles me davam pinga com açúcar numa xícara de chá para mim comer aquele açúcar, beber aquela pinga docinha, pra mim poder dormir pra não chegar ao fim da baixaria. Então era assim... as brigas muitas vezes começavam porque a dona do dinheiro era minha avó, né, todos trabalhavam pra ela.

C. Trabalhavam fazendo o que?

A. Na roça.

C. A roça era dela?

A. A roça era dela. Sitiante na época que chamava. Hoje ou é fazendeiro, ou é trabalhador rural. E era minha avó que pagava eles, dava dinheiro.

C. Eles eram os filhos dela?

A. Os filhos dela. Então sempre tinha aqueles que trabalhava mais, que achava que tinha direito a mais, o outro que não concordava, então sempre começava, mas isto já começava porque tava todo mundo travado, todo mundo pra lá de Bagdá...

C. Ah, então era por isto que começavam as brigas?

A. Começavam as brigas

C. E as pessoas lá, tua vó, teus tios, bebiam de fim de semana ou durante a semana?

A. Só no fim de semana. Mas sábado e domingo era...

C. Ta. Tua mãe também?

A. Também.

C. E como era em relação aos cuidados com você, Ana, se tava todo mundo alcoolizado? Porque você tinha uns 4-5 anos.

A. Quanto a isto eles me tratavam bem, não me batiam não me judiavam, isto eu não posso reclamar não. Mesmo ruim do jeito que estavam minha avó se preocupava de me por na cama, me dar comida, minha mãe. Meus tios também, porque eu era, como diz, acho que no tempo deles acho que eles achavam que eu era a coitadinha, né, porque a mãe separou do meu pai aos 6 meses, né. Eu nem cheguei a conhecer meu pai. E neste meio de tempo, que... porque minha mãe foi lá pro sitio da minha avó e meu pai de verdade, a família dele morava em (cidade do interior), e então começou o trâmite do divórcio, divórcio não, porque naquela época era desquite, mas nunca que meu pai tenha me mandado uma bala, um presentinho e quando ia se lá para acerto, para alguma conversa sobre o desquite e tudo, aí ia aquele monte de homem, advogado, amigo, pai dele, irmão dele, aquele monte de homem. Eu só sabia que ele tava ali naquele meio porque minha mãe se preocupava em me dar um banho, me trocar bonitinha, mas eu olhava assim no meio de todos. Eu não sabia quem era quem, quem era meu pai.

(linhas 09-49)

Como parte da construção de sua narrativa dramática sobre a infância, neste extrato Ana conta como se deu o início de seu consumo de bebidas alcoólicas. Posiciona-se como "Ana que era alimentada com bebidas alcoólicas pelos familiares na infância". Este posicionamento, aliado ao discurso psicológico sobre a aprendizagem social, de que comportamentos aprendidos na infância influenciarão a vida adulta, será importante para a construção do problema com bebidas alcoólicas para Ana. Durante a entrevista esta experiência será usada na construção de uma mulher que foi marcada desde a infância para o consumo de bebidas alcoólicas e que não pode fazer nada para mudar. Construirá uma narrativa onde mágoa, revolta e impotência frente ao problema serão descritos. No final deste extrato, influenciada pelo discurso de que adultos alcoolizados agem com negligência no cuidado das crianças, pergunto sobre 
como era tratada. Ela se posiciona como 'Ana que era bem cuidada pelos familiares'. Estes dois posicionamentos ('Ana que era alimentada com bebidas alcoólicas pelos familiares na infância' e 'Ana que era bem cuidada pelos familiares') ilustram a ambivalência com que irá construir em sua narrativa seus sentimentos em relação à família, ora grata por estes terem-na protegido e ora magoada por terem-na exposto a riscos.

Aos 7 anos, preocupada em colocar-Ihe na escola, sua avó vendeu o sítio e mudaramse para cidade. Ana ficou super feliz com a mudança e com a possibilidade de estudar.

C. E como foi pra você mudar pra cidade? Você queria, não queria?

A. Ah, naquela época criança não tinha muito querer, né, bem? Era aquele negócio, olhava e você já abaixava o rabinho e pronto, caia no mundo.

C. Mas você lembra de ter gostado ou não?

A. Ah, eu gostei, porque eu sempre gostei muito de estudar, então cada palavra que eu aprendia era uma dádiva pra mim.

C. Ai que delícia! E você começou a estudar na cidade?

A. Na cidade.

(linhas 227-234)

C. O que você sente, como é pra você isto?

A. Não sei te explicar. Silêncio

C. Tá.

A. E o sentimento que eu sinto eu não sei definir. Ai eu fui ficando mocinha e tudo, ai eu cresci, depois minha avó vendeu o sitio e foi pra cidade, aí já mudou, já não existia, existia assim o vinhozinho, a cervejinha e tudo, mas já não era como no sítio.

C. Ah, quando foi pra cidade mudou?

A. Mudou, aí já começaram a ser mais social, a bebida já começou a ser mais social.

C. Porque você acha que teve esta mudança?

A. Não sei, não sei se porque lá no sítio era só família e longe, porque um sítio era longe do outro, então ele num tinham ninguém para ouvir, interceder ou pra reclamar das baixarias, né. Mas quando foi pra cidade mudou.

C. Porque você imagina que eles bebiam desta forma no sítio?

A. Ah, num sei te explicar. Porque a mãe da minha avó eu não conheci. Eu conheci da minha avó pra frente, minha avó, minha mãe, eu e os que vieram depois de mim. E da parte do meu pai eu conhecia algumas tias, mas avô, avó da parte dele eu não cheguei a conhecer.

C. E você sabe se na família do teu pai o pessoal também tinha este costume de beber?

A. A sim, todo mundo sempre foi de beber, mas como dizem, bebiam socialmente, mas eu não sei o que é beber socialmente, porque se bebe um litro de whisky, não sei, mas acho que já não é um beber social.

C. Este consumo que a tua família tinha, você acha que era um beber social?

A. Não, não era social

C. Porque que não era social?

A. Porque eles bebiam demais, Mas eles beberem eu não me importo. A única revolta que eu tenho é eles fazerem o que faziam, de me dar pinga com açúcar, quer dizer, eu já tinha genética, aí eu provando, consumindo, porque na verdade eu consumia.

C. E isto é uma coisa que você fica brava de pensar nisto.

A. Fico brava, chateada (chorando). 
No primeiro extrato, Ana se posiciona como 'Ana que respeitava os adultos na infância', construindo-se como alguém que recebeu uma educação rígida na infância, que aprendeu a respeitar as figuras de autoridade (aqui representada pela família) e que, portanto, recebeu boa educação. Posiciona-se também como 'Ana que adorava estudar', posicionamento que ajudará a construí-la em nossa conversa como uma pessoa curiosa, que gosta de aprender coisas novas e aprimorar-se.

O segundo extrato também diz respeito à mudança da família para cidade. Pergunto sobre o que sente ao me contar sobre as brigas dos familiares quando estavam alcoolizados e ela me conta sobre a mudança que aconteceu no padrão de consumo da família quando estes mudaram para a cidade. Neste extrato ela negocia sentido para o consumo social e consumo problemático, apontando que o consumo de bebidas alcoólicas feito pela família mudou quando estes foram para a cidade, utilizando como explicação o fato de terem que se preocupar com a opinião dos vizinhos, com o uso do discurso de que o consumo de bebidas alcoólicas pode ser regulado pelo meio social. Este discurso será importante na construção de seu consumo de álcool, que apesar de tê-la acompanhado durante quase toda sua vida, será construído como problemático apenas nos últimos anos, quando não é legitimado pelos filhos adultos. Utiliza também o discurso da genética para explicar o consumo, posicionando-se como 'Ana que tem genética para o alcoolismo'. Este discurso, associado ao discurso da aprendizagem social, ajudarão a compor seu consumo de bebidas alcoólicas como algo que foi determinado genética e psicologicamente, narrando impotência frente a isto e mágoas de sua família.

Desta forma, o consumo social é descrito como aquele regulado pelo contexto social, com consumo em quantidades menores e sem levar a violência.

Além dos estudos, ajudava financeiramente vendendo verdura para a avó. Sonhava em ter uma máquina de costura e guardava todo seu dinheiro para isto. Sua mãe casou-se novamente e o padrasto, apesar de ser um homem bom, vivia pedindo dinheiro emprestado a Ana, usando todas suas economias. Ana, sempre preocupada em não dar trabalho ou atrapalhar, resolveu deixar a escola aos 11 anos para poder apenas trabalhar.

C. A tua avó achava isto?

A. Porque minha mãe fazia doce, meu padrasto tinha bar e eu ficava a manhã inteira... eu entrava no grupo escolar a uma e meia da tarde e ficava até a uma hora lavando louça, forninho, canudinho e num tinha uma pia... era uma baciona e você ficava o dia inteiro naquela posição e uma torneira. E minha avó achava que eu era empregada doméstica dele, porque se ele fosse pagar uma empregada, "quanto custa a empregada?" porque "ela tá fazendo os serviço da empregada" e ele "não, porque a 
senhora tem dinheiro, a senhora pode pagar", nisto eu entrei, porque nunca fui de ficar escutando conversa, porque a olhada da minha avó é terrível e da minha mãe também, mas este dia eu parei porque eu vi que eles tavam discutindo, "não a senhora tem pagar porque tem dinheiro", "não ela é empregada tua", e eu entrei no meio dos dois e falei, "olha, ninguém tem que brigar por causa de mim, como eu não posso trabalhar e estudar, eu vou trabalhar e não vou estudar. E ninguém vai precisar me sustentar".

C. Ai você tava com quantos anos?

A. Uns 10 pra 11

C. Foi outro momento de mudança...

A. Foi outra mudança, isto eu sinto até hoje (chorando) porque minha irmã formou, é professora formada, meu irmão é engenheiro civil e eu não estudei. A minha irmã nunca exerceu a profissão, mas num lembra, num sabe nem as mudanças que existem no mundo, quer dizer, completamente desligada.

C. Você já pensou em voltar a estudar, Ana?

A. Hoje não, já tive vontade, mas é aquele negocio, a idade vai chegando, a gente vai ficando meio cansada.

C. É... porque de repente é uma coisa que você podia fazer, voltar agora pra quinta serie.

A. Hoje não, o que eu tinha que ter aprendido na época, não aprendi. Hoje minha cabeça não ajuda mais não... Aí, comecei a trabalhar, foi uma coisa e outra e outra.

C. Você continuou morando com ele?

A. Continuei, continuei lavando, trabalhando do mesmo jeito, limpando, tudo do mesmo jeito. Porque eu me revoltei e falei que eu tinha que trabalhar, mas a minha obrigação dentro de casa tinha que ser feita. Nunca queixei, nunca briguei, nunca reclamei.

C. Aí nesta época que sua mãe casou de novo, tua mãe bebia nesta época?

A. Não, aí parou durante uns tempos e aí depois já começou de novo, mas aí também era o seguinte: o meu padrasto bebia e ele pegava e ele levava lá dentro pra ela, porque ele tinha bar e ele levava pra dentro pra ela. Porque ele num permitia nem que ela chegasse na porta do reservado. Ele era muito ciumento. Então era ele que ia buscar as bandejas de doce que ela fazia, os pernis na cozinha, minha mãe não ia pra lugar nenhum, o único lugar que ela ia era numa farmácia se precisasse tomar uma injeção, ainda assim se o farmacêutico pudesse ir em casa...

C. Ele não deixava ela sair na rua...

A. Não deixava... e aí começou, ela ficava lá dentro socada o dia inteiro, trabalhando o dia inteiro e de noite ele mandava os copos de caipirinha, os copos de vinho.

C. E como ela ficava nesta época, Ana?

A. Ai, sozinha, ela ia deitar, numa boa. Não brigava com ele, não brigava comigo, não tinha ninguém pra brigar.

(linhas 307-349)

No inicio deste extrato, Ana conta que seu padrasto e sua avó haviam discutido para decidir quem deveria pagar pelos estudos de Ana. Ela então se posiciona como 'Ana que teve que parar de estudar para trabalhar', posicionamento este que a deixa muito triste e que irá ajudá-la a construir-se em nossa conversa como filha que não teve os mesmos privilégios que os irmãos e como alguém que teve que deixar coisas que eram importantes para ela em função do trabalho. Em relação aos irmãos, também se diferencia destes, dizendo que a irmã, apesar de ter estudado, é desligada das coisas que acontecem no mundo. Deixa implícito aqui que apesar de não ter completado os estudos, é uma pessoa mais culta do que sua irmã. Convido-a a pensar na possibilidade de voltar a estudar, ao que ela se posiciona como 'Ana que 
está velha para voltar a estudar'. Ao contar sobre o conflito entre a avó e o padrasto, novamente se posiciona como 'Ana que respeita as figuras de autoridade' e diz que parou de estudar e trabalhava para o padrasto. Aqui novamente constrói-se como alguém que recebeu boa educação. Pela descrição dada por ela do padrasto como um homem rígido, pergunto sobre o consumo de bebidas alcoólicas feito por sua mãe depois de casada. Ela relata que a mãe continuou a beber, com a permissão do padrasto que tinha um bar e lhe dava bebidas. O consumo aqui é descrito como algo que acalentava o trabalho e a solidão da mãe. Mais tarde, ao narrar seu consumo, este também aparece construído como companheiro de trabalho e de solidão.

Conheceu um rapaz mais velho, gostou dele e esperou ansiosamente completar 16 anos para poderem se casar. Dias antes do casamento, Ana ficou sabendo que seu noivo resolveu the fazer uma surpresa: convidou seu pai para vir à cerimônia e levála ao altar! Como ele poderia ter feito isto, se ela nunca teve contato com o pai, se este nunca se preocupou em apresentar-se a ela? Como ela diria ao padrasto que ele não a levaria ao altar? Não pode retrucar ao noivo, afinal, sabia que devia respeitá-lo, mesmo sentindo imensa mágoa por ter sido tratada com tamanho desrespeito. Seu pai veio, entrou com ela na igreja e sua mãe e padrasto não foram assisti-la casar.

C. Você acha que ele fez isto pra te dar um presente?

A. Não acredito que foi com boas intenções, porque boas intenções a gente faz quando percebe que a pessoa tem o desejo e eu nunca disse que eu queria conhecer o meu pai. Porque um pai que nunca manda um cartão de Natal, uma bala que fosse, não é pai. Porque pai é quem cria, então o pouco que eu convivi com meu padrasto eu acho que ele é mais meu pai do que o outro, a minha avó foi mais meu pai.

C. E como foi teu casamento, teu pai chegando...

A. Pra mim num tive emoção nenhuma, pelo contrário, senti revolta, tinha vontade de mandar todo mundo embora, mas como diz a boa educação você tem que engolir sapo, né. Então só chorei bastante quando fui na minha mãe e contei e ela falou "já estou sabendo, nós não vamos no casamento". Pra mim acabou. Meu pai entrar comigo na igreja?

C. E ele entrou?

A. Entrou, entrou. Isto daí eu não perdôo, eu posso viver 200 anos que eu não vou perdoar.

C. Não perdoa teu ex-marido?

A. Não. 
Neste extrato Ana vinha me contando sobre o convite que o noivo fez ao pai para vir ao casamento deles. Perguntei sobre a possibilidade de construir este convite como um presente que o noivo queria dar a ela. Ela não aceitou esta construção, posicionando-se como 'Ana que nunca foi cuidada pelo pai', posição que legitima sua mágoa do marido por tê-la colocado nesta situação. Ao relatar seu casamento, novamente posicionou-se como 'Ana que respeita figuras de autoridade', aqui representada pelo noivo. Este posicionamento, aliado ao discurso dos papéis sociais de gênero, que posicionam a mulher como obediente ao marido, ajudam-na a construir-se em nossa conversa como uma mulher de respeito, que recebeu boa educação e que aceitava seu lugar social.

Entretanto, sua obediência descomedida terminou na primeira semana de casamento. Foi visitar a mãe e quando chegou em casa, apanhou do marido, pois não deveria ter saído. Sabendo que seu casamento tinha terminado no altar, enfrentou o marido, dizendo que iria todos os dias visitar sua família! E com isto, cúmplice da mãe e da avó, conhecedora das dores do mundo adulto, num importante ritual de passagem, sem ter do que se esconder, passou pelo bar, comprou cachaça e preparou uma caipirinha para tomar com a mãe. Só bebendo para agüentar este casamento mais um pouco! Com isto, apesar de dormir com o carrasco, podia passar suas tardes em família.

C. Logo que vocês casaram?

A. Logo depois da primeira surra, porque ele me bateu por ir na casa da minha mãe. Eu falei "ah, não vai ter jeito, só uma bebida pra conseguir levar este negocio um pouco mais!"

C. E você lembra a primeira vez que você bebeu?

A. Lembro.

C. Como é que foi?

A. Foi... eu fui pra casa da minha mãe, e meu padrasto tinha lá, nesta época ele tinha loja de calçado, ele era dono de bar, mas ele não era de beber em bar, ele bebia em casa e ele comprava e deixava lá pra beber. Aí, depois, já no outro dia eu falei pra ele, "você me bateu porque eu fui na casa da minha mãe, eu fui uma vez só, porque a gente casou e eu não fui lá mais. Agora só vou te falar uma coisa, eu vou todo dia na casa dela porque eu tenho direito de ver a minha mãe, eu não nasci de chocadeira". "Se você vai eu vou te bater todo dia". "Então vamos ver". Aí tinha uma irmã mais velha dele e um cunhado e eu fui lá e falei, "olha, aconteceu isto e isto, ou vocês conversam com ele ou ele vai me matar porque eu decidi que vou todo dia na casa da minha mãe. E ele falou que vai me bater todo dia". Ai ela falou "não você vai e vamos ver se ele vai te bater, ele pode até te bater por outro motivo, mas porque você foi na casa da tua mãe, não". Ai no dia seguinte que eu fui na casa da minha mãe, eu não tive vergonha, parei na frente e falei, "me dá um copo de pinga que eu vou fazer caipirinha pr mim e pra minha mãe". Ai eu fiz caipirinha e fiz e tomei eu e minha mãe. Daí pra frente, bem... 
Este extrato foi retirado de um momento da conversa onde perguntei se ela bebia depois de casada. Ela conta que apanhou logo na primeira semana de casada e em diálogo como 'Ana que respeita figuras de autoridade' e 'Ana mulher de respeito', diz que era preciso beber para agüentar o casamento. O consumo de bebidas alcoólicas é descrito aqui como comportamento que Ihe ajudava a tolerar situações difíceis. Em outros momentos, diz que não podia se divorciar já que ficaria "falada" com isto. Com o forte discurso dos papéis sociais de gênero apontando para o respeito da esposa ao marido e ao casamento, Ana parece negociar, em nossa conversa, construções que legitimem seus comportamentos de modo que continue sendo descrita como mulher de respeito. Desta forma, constrói a narrativa sobre seu consumo de bebidas alcoólicas como algo que ajudava a manter seu posicionamento de 'Ana mulher de respeito', já que com isto continuaria casada e subjugada ao marido. Ao relatar que enfrentou o marido, dá legitimidade a seu posicionamento de 'Ana mulher de respeito' ao utilizar o discurso dos vínculos familiares, priorizando o relacionamento com a mãe. Esta legitimidade é também sustentada por sua cunhada que Ihe apóia em sua decisão.

Engravidou logo depois do casamento e teve dois filhos. Se não fosse por eles, provavelmente teria enfrentado a sociedade da época e pedido o divórcio. Mas, graças a Deus, o marido era caminhoneiro e ficava pouco em casa. Também contribuía pouco financeiramente em casa. Mas Ana se virava, fazendo pequenos artesanatos para vender e contando com a colaboração de amigos.

C. Você tem os 2 filhos?

A. Só os 2. Aí depois, com as crianças, você vai dando um tempo. Toda vez que eu falei "vou largar, porque eu apanhei a vida inteira...'. A vida inteira, porque ele bateu aos 12 dias de casado, tomou o gosto pela coisa e continuou. E a gente naquela época tinha que apanhar e falar "Amém", não tinha o direito de se revoltar, de tomar atitude. Cada vez que falava em separar, a criança começava a chorar, a ficar doente, chorava na escola o tempo todo, abaixava o rendimento, aí vinha o professor, o diretor da escola, conversar, apaziguar, só que só vinha comigo porque ele mesmo era motorista de caminhão e não ficava, então eu era o pai e mãe desta criança, só vinha comigo...

C. Por um lado era bom que ele num ficava então

A. Nossa senhora, se ficasse 24 horas dentro de casa acho que ele me matava!

C. Ele era bem violento, mesmo?

A. Muito violento.

C. E neste período que você ficou casada com ele você bebia alguma coisa de bebida alcoólica?

A. Pra te falar verdade, bem, comecei a beber logo depois da primeira surra.

C. Logo que vocês casaram? 
Este extrato segue um relato em que diz que sua avó recomendou que se separasse quando soube que ela estava apanhando do marido. Com o discurso dos papéis sociais de gênero, posiciona-se como 'Ana que não podia enfrentar o marido' e com isto justifica sua decisão de continuar casada apesar de apanhar. O discurso dos papéis sociais de gênero associado ao discurso psicológico de que a separação dos pais pode trazer problemas emocionais aos filhos sustentam o posicionamento de 'Ana que era uma mãe preocupada com os filhos'. Este posicionamento também é usado para explicar sua decisão de continuar casada.

Com estes posicionamentos, Ana vai se construindo em nossa conversa como uma mulher que sofreu com o marido, mas que impunha respeito e era preocupada em ser boa mãe.

Falando em amigos, certo dia, uma amiga que estava de mudança para São Paulo, ofereceu-Ihe a gerência do posto telefônico do município. Uma super oportunidade de ganhar muito dinheiro! Ana titubeou a princípio, sabia que era muita responsabilidade, mas depois, motivada pela amiga e pela avó, aceitou.

A. ...Nossa, mas eu não posso ir assim, tô tão feia? "Não, você vai falar com o chefe e pra falar com o chefe você tem que ir bem arrumada". Mas sabe quando você tá flutuando e você não sabe o que tá acontecendo? Foi assim, bem, eu ganhei de bandeja na minha porta! Eu fui e deu tudo certo. Foi firmado um contrato e tinha que ter o fiador, da cidade, alguém que tinha dinheiro, era como alugar uma casa, porque eu ia mexer com o dinheiro da telefônica. Porque na época, todas as contas da cidade, não eram pagas no banco, as contas era eu que recebia no posto, então precisava de um fiador pra garantir que eu não ia sumir com o dinheiro. E ele tava viajando naquela época e eu falei "como eu faço?", ele tinha apelido de Gasolina, "o Gasolina tá viajando" ela falou "O que? Você apanha, passa necessidade e você tá esperando ele chegar pra pedir autorização? 0 contrato tá fechado, minha filha, você vai catar tuas tralhas e vai trazer pra baixo porque a minha já ta saindo. Na sexta ela já tava tirando, e a tarde eu já tinha que entrar com minha. Aí tinha um amigo dele que gostava muito das crianças, ele era casado mas não tinha filho. Ele adotou as crianças com se fosse filho dele, ia todo dia em casa passear com as crianças. Falei 'o que faço?', ele falou 'peraí', falou pro outro 'empresta o caminhãozinho que vou fazer a mudança da Ana'. 'Mudança? Mas perái...' 'Depois eu te explico, agora eu não tenho tempo, tenho que fazer hoje'. Ele que juntou as coisas, porque eu tava em transe, sabe quando você não sabe o que tá acontecendo?

C. Mas fez mudança porque?

A. Da minha casa, porque quem tomava conta de lá tinha que morar lá.

C. $\mathrm{E}$ ai levou tuas coisas e do teu marido?

A. Levou o que tinha na casinha alugada, levou as nossas coisas,. A telefônica dava casa, água e luz, fora o salário e mais $17 \%$ da renda das ligações da cidade.

C. Era um emprego ótimo, então...

A. Ótimo, mas nem juiz ganhava como eu...

(linhas 576-601) 
Este extrato foi retirado de um momento de nossa conversa em que conta sobre o dia em que sua avó e sua amiga lhe procuraram dizendo que fosse se encontrar com o chefe do posto telefônico para entrevista de emprego. Posiciona-se como 'Ana que estava excitada com a oportunidade de um bom emprego', 'Ana que teve sorte por ter sido indicada para o emprego', 'Ana que ficou preocupada por não ter o consentimento do marido' e 'Ana que teve apoio de amigos e familiares para aceitar o emprego novo'. Estes posicionamentos são importantes para justificar sua decisão de aceitar o emprego sem que o marido soubesse. Para que pudesse continuar a se posicionar como 'Ana mulher de respeito' era preciso que outras pessoas legitimassem sua decisão de fazer algo sem o consentimento do marido. Sua decisão também é legitimada quando se posiciona como 'Ana que ganharia muito dinheiro'. Este relato ajuda, em nossa conversa, a construí-la como uma mulher que, por sorte, teve boas oportunidades de emprego e que por dedicar-se com afinco a elas, conseguiu sua autonomia e independência financeira.

O marido, quando ficou sabendo, deu-lhe uma surra e exigiu que ela abandonasse tudo. Ana, com dificuldades para criar os filhos, sabia que esta era uma concessão que não valeria a pena fazer. Novamente enfrentou o marido e ficou responsável pelo gerenciamento de todas as ligações da cidade. Adorava seu trabalho, tinha duas funcionárias, ganhava muito bem e, com isto, conseguiu estudar os filhos e dar a eles uma vida de conforto.

C. E o teu marido, o que ele achou?

A. O que que ele achou? Ele queria me bater e levar as coisas de volta. E eu falei "o que?" Nesta altura, eu tive que aprender no sábado e no domingo, na parte da manhã, o que tinha que aprender do burocrático da telefônica, porque na segunda ela já começava a trabalhar. Aprendi, marquei tudo. Ela falou "qualquer coisa você liga pro seu Ribeiro que ele te dá apoio, ele vai pedir pra alguém vir te orientar". Eu falei "vou fazer o possível pra não ter que pedir ajuda, mas se precisar eu peço". Isto eu tremia que nem vara verde, "ai, será que eu vou dar conta?". E ai ele chegou no domingo... me bateu, "aqui você não fica, você vai voltar pra onde eu te deixei, então, quer dizer, o marido sai, quando volta a mulher já tomou as decisões, já mudou, já ta trabalhando, e o trouxa aqui não ta sabendo de nada." Foi um pandemônio que ele aprontou.

C. Imagino...

A. E porque ele trabalhava de caminhoneiro nesta época, já encostou o caminhão na guia do lado "porque to tirando as minhas coisas". "Tuas coisas não, porque a gente ganhou então são nossas coisas. E pra começo de conversa, você pode tirar porque você vai sozinho, porque eu e as crianças fica, eu não vejo a cor do dinheiro, eu não tenho o que comer dentro de casa, as crianças passam fome, você viaja, e come do bem e do melhor porque o patrão paga a diária, mas você não se preocupa se teus filhos tem leite, quem tá dando leite pros teus filhos, quem tá dando uma fruta, e você acha que eu ia dizer não, eu não posso porque o meu marido tá viajando, mas nem morta eu ia fazer um troço deste, porque pelo menos aqui você não precisa trazer o teu dinheiro, porque pra mim e pros meus filhos eu tenho". E assim, graças a Deus trabalhei quase 14 anos e foi ali que eu ainda consegui levar os quase 16 nas costas (refere-se ao tempo de casada), consegui dar do melhor pros meus filhos, estudo...

(linhas 602-624) 
Neste extrato Ana relata a atitude do marido ao saber de seu novo emprego. Posiciona-se como 'Ana que enfrentou o marido', 'Ana que estava se dedicando para realizar um bom trabalho', 'Ana que estava ansiosa com o novo trabalho', 'Ana que aceitou o trabalho para ter dinheiro para oferecer uma boa vida aos filhos'. Estes posicionamentos são importantes para legitimarem sua decisão de aceitar o emprego e enfrentar o marido sem que deixasse de se posicionar como 'Ana mulher de respeito', já que as decisões que tomou ajudaram-na a ser uma boa mãe e a manterse em um casamento infeliz.

Então, o tempo passou, o sistema telefônico mudou, as pessoas passaram a fazer e receber ligações diretas de suas próprias casas e Ana perdeu seu emprego.

C. E Ana, neste tempo que você tava trabalhando na telefônica você continuava a tomar caipirinha daquele jeito?

A. Tomava.

C. Tomava a tarde?

A. Sempre à tarde.

C. À tarde, final de tarde quase noite ou depois do almoço à tarde toda?

A. Não, à noite.

C. Você ficava sozinha com teus filhos à noite em casa?

A. Ficava

C. Ele não ficava em casa?

A. Ele viajava.

C. E você tomava quanto, mais ou menos?

A. Ah, bem, é como diz, você bebeu o primeiro e o segundo e depois você perde a conta. Eu tomava bastante.

C. Você perdia a conta, então...

A. Perdia a conta, mas nunca deixei de cumprir com a minha obrigação, no serviço, nunca deixei de cumprir com a minha obrigação com filhos, com a casa, porque a minha casa era de tábua bem, e era encerada que parecia sinteco e não era, era naquele escovão de... de ferro... no cabo...

C. E Ana, você bebia tanta caipirinha, no outro dia você não acordava meio quebrada, assim...

A. Não. (fica monossilabiaca quando conversa sobre isto...)

C. Não, não acordava sentindo mal?

A. Acordava bem. E pra mim também era assim, eu nunca fui de dormir muito, podia ir numa festa assim, voltava às 5 horas da manha, 6 horas eu tava de pé, porque eu tinha que fazer um café, tomava um café , a menina vinha tinha que limpar o posto, abrir o posto. Mas eu nunca deixei as minhas obrigações...

C. E nesta época, você achava que você tinha algum problema com bebida ou não?

A. Não.

C. Não? Pra você bebia nesta época porque? O que que você pensa?

A. Ah?

C. Você bebia nesta época porque?

A. Não penso nada. Se você me perguntar o motivo eu não sei.

C. Assim, mas, por falta do que fazer, pra relaxar...

A. Não por falta do que fazer não, bem, porque eu tinha um bom emprego que me ocupava o dia inteiro, 24 horas por dia, eu era responsável, as moças que trabalhavam lá 
eram minha responsabilidade também, eu vendia Avon naquela época, vendia semi-jóia, vendia roupa...

C. Falta do que fazer não era mesmo, você tava cheia de coisa

A. Não, não era, eu sempre fui muito ativa, não gostava de ficar parada, sempre fui muita ativa, com o dinheiro que eu ganhava eu não precisava sair vendendo estas coisas, mas eu gostava.

C. Sempre gostou, né, desde criança

A. Sempre, sempre.

C. Ai no final vocês acabaram se separando então, ai foi quando a telefônica mudou, fechou.

(mudo de assunto pois parece que ela fica ofendida de conversar sobre o uso de álcool)

A. É, já tinha fechado, já tinha mudado o sistema.

(linhas 661- 705)

Neste extrato, resolvi investigar como era o consumo de bebidas alcoólicas de Ana na época em que ela trabalhava no posto telefônico. Frente às minhas perguntas, ela se posiciona como 'Ana que bebia bastante'. Em seguida, utiliza o discurso do senso comum de que a pessoa que tem problema com bebidas alcoólicas deixa de cumprir com suas obrigações. Com o uso deste discurso, posiciona-se como 'Ana que nunca deixou de cumprir com suas obrigações' e, portanto, 'Ana que não tinha problema com bebidas'.

Questiono este posicionamento, posicionando-a como 'Ana que deveria ficar quebrada depois de beber tanto'. Ela não aceita este posicionamento e novamente posiciona-se como 'Ana que nunca deixou de cumprir com suas obrigações' e com isto reafirma seu posicionamento de 'Ana que não tinha problema como bebidas'. Mergulhada nos discursos médico e psicológico de que há causas para o consumo abusivo de bebidas alcoólicas, pergunto sobre o que ela pensa sobre isto. Ela se posiciona como 'Ana que não pensa sobre os motivos pelos quais consome bebidas'. Utilizando novamente os discursos médico e psicológico de que o consumo de bebidas de mulheres está associado com ansiedade e com o tempo livre, posiciono-a como 'Ana que bebia para relaxar ou por não ter o que fazer'. Este posicionamento é recusado com veemência por Ana, que durante toda nossa conversa vem se construindo como uma mulher trabalhadora e que cumpre suas obrigações. Ela então se defende, posicionando-se como 'Ana que trabalhava 24 horas por dia', 'Ana que era responsável', 'Ana que era muito ativa', 'Ana que trabalhava mesmo sem precisar do dinheiro'. Percebo que havia lançado mão de um discurso que desconsiderava todo seu relato e, a fim de reparar este erro, posiciono-a como 'Ana que sempre foi muito ativa'.

Este extrato é muito importante para compreendermos a construção que Ana faz sobre seu consumo de bebidas em nossa conversa. Apesar de dizer que bebia bastante, Ana não considera que seu consumo era problemático, já que cumpria suas obrigações como dona de casa, mãe e trabalhadora. 
Nesta época já havia conseguido o divórcio e com os filhos grandes, resolveu mudarse para São Paulo. E como esta vida é cheia de ironias e surpresas, foi acolhida com amor pela viúva de seu pai. Aventurou-se pela capital em diferentes empregos, deu risada das vezes em que ficou perdida na cidade grande e foi substituir uma amiga em férias no PABX de uma empresa multinacional. Nossa! Ficou encantada pelo trabalho! Em uma multinacional tudo funciona de modo organizado e respeitoso! $\mathrm{E}$ com muito trabalho, via o tempo passar rápido. Disse à amiga que seu sonho seria trabalhar em uma empresa assim. Sonho dito, ditou seu destino: semanas depois, a amiga Ihe ofereceu trabalho na Mercedes Benz, onde Ana ficou por 10 anos, até aposentar-se.

C. E você tinha seguro desemprego? Tinha algum dinheiro pra se manter?

A. Não, porque o hotel me mandou, e eu tinha os meus direitos, naquela época tinha o aviso prévio, naquela época sempre tinha um dinheiro a mais pra gente. Ai com este dinheiro eu dei de entrada uma casa lá em (cidade em que morava), popular, comprei de uma pessoa, e com a outra metade em comprei roupa e então ficava viajando, vendendo roupa, ia de lá pra cá, daqui pra lá, vendi muito, viu.... como diz, não passei fome por estar desempregada não. Ai esta mesma amiga que me aconselhou a fazer o curso da telefônica, ela falou, neste ano que eu fiquei desempregada também, ela me arrumou pra eu cobrir férias na Volkswagen e eu fui cobrir, fiquei 4 meses cobrindo férias lá, mas assim, era só cobrir férias, acabou, acabou e no dia que eu fui agradecer por ter me arrumado este bico e tudo, eu falei, eu ainda vou trabalhar pra uma multinacional, o troço bom, ela falou, mas não eu muito serviço? Porque é serviço pra caramba. Mas o troço bom, é tão bom, porque você chega, você piscou e já acabou o dia, porque você não vê o tempo passar. E ela falou "mas você gostaria de trabalhar numa multinacional?" Lógico, era tudo o que eu queria, além do que o salário é bom, né? Ai a chefe da telefônica da Mercedes bens ligou pra ela, falando que tava precisando de uma telefonista boa, pra começar logo, mas com uma certa experiência. Ela falou, vou te mandar uma que cobriu até ferias na Volkswagen, ah, então me manda amanha. Amanhã não, porque ela tá viajando, mas eu vou ligar pra ela e ela tá de volta já. Eu tinha acabado de chegar e ela me liga, vem que eu tenho um serviço pra você bom, mas eu acabei de chegar, mas volta. Aí deixei a sacola de roupa lá, minha filha, falou, deixa que eu vendo pra senhora. Ai é aquela burocracia, exames, antecedentes criminais, nossa senhora, foi 2 meses e meio nesta ladainha ainda, mas entrei! (diz, triunfante, como uma vitória!)

C. Que beleza!

A. Nossa, quando ela falou você pode vir vai começar tal dia!

C. Você pediu e conseguiu, né?

A. Pedi e consegui, mas a minha sorte, graças a Deus, foi o comentário que fiz com minha amiga, né?

(Linhas 757-784)

C. Ana, e nesta época que você tava em São Paulo, que você ficou na Mercedes, na Telefônica, você tava bebendo ou não?

A. Bebi.

C. Porque você trabalhava das 8 as 18 né, você bebia depois?

A. Depois.

C. Você bebia sozinha, você saia?

A. Não, sozinha.

C. Na hora que você chegava em casa?

A. É. 
C. E você bebia o que?

A. Olha, dependia de como tava o bolso, se dava pra comprar uma coisa melhor, comprava algo mais caro, senão uma cerveja, uma batidinha.

C. E você bebia quanto nesta época?

A. E como eu te disse, eu nunca fiz questão de saber o quanto, o tanto.

C. Entendi.

A. Eu tomava, então, se via que num queria mais, ia deitar, dormir. Bebia enquanto tava trabalhando na Mercedes, quando tava trabalhando, não. Após o serviço, que eu chegava em casa e tudo, tomava lá na minha casa, ai eu comprava na minha casa, tomava em casa.

(linhas 813-830)

No primeiro extrato, Ana conta sobre os diversos empregos e formas que encontrou para ganhar dinheiro quando se mudou para São Paulo. Posiciona-se como 'Ana que se virava para arrumar dinheiro'. Conta então sobre experiência de trabalhar em uma multinacional, posicionando-se como 'Ana que sonhava em trabalhar em multinacional' e fala, emocionada, sobre como conseguiu este emprego depois de uma indicação de uma amiga. Ao terminar este relato, posiciona-se como 'Ana que conseguiu realizar o sonho'. Neste momento, a narrativa de sua vida (de menina oferecida no carteado pelo pai - criança que recebia pinga dos familiares para dormir - que começou a trabalhar desde cedo - que teve que largar os estudos para trabalhar - que casou com um homem violento que traiu sua confiança no dia do casamento - que teve que se virar para sustentar os filhos - que enfrentou o marido para conseguir um bom emprego - que se divorciou e mudou-se para São Paulo que se aventurou em diversos trabalhos em São Paulo) atingiu o ápice, já que havia conseguido vencer, atingir seu sonho maior, orgulhar-se por ter trabalhado e aposentado em uma multinacional. É o final de uma narrativa em que se constrói como uma pessoa que sofreu diversos percalços na vida, mas teve um final feliz, saiu vencedora. Neste momento tenho a impressão de que ela gostaria de terminar a conversa aqui, posicionada como 'Ana que venceu na vida'.

No segundo extrato, insiro novamente o assunto "consumo de bebidas alcoólicas" e Ana, que vinha contando espontaneamente suas batalhas e vitórias na vida, torna-se monossilábica. Posiciona-se como 'Ana que bebia em casa sozinha depois do trabalho', 'Ana que não se preocupava em saber a quantidade que bebia', 'Ana que bebia e ia dormir'. Ana novamente utiliza o posicionamento 'Ana que cumpre suas obrigações' para construir seu consumo como algo que não é problema. Entretanto, o tom desconfiado e desconfortável com que responde às minhas perguntas, parece indicar que na relação comigo, apresentada a ela como psicóloga e pesquisadora sobre mulheres e o uso de bebidas alcoólicas, ela teme ser posicionada de modo não desejado, como 'Ana que tem problema com bebidas'. Não é assim que ela quer ser conhecida, quer ser conhecida como 'Ana que venceu na vida'. 
Como sua família estava em Ribeirão Preto, voltou para o interior, comprou um apartamento em um bom bairro da cidade e passou a viver de sua aposentadoria. Sua mudança foi importante na vida da mãe e da irmã, pois ajudou bastante em momentos em que estas estavam adoecidas. Em casa, tem a companhia de seu filho e de netas, que ficam com ela durante a semana quando trabalham na cidade. Fica inconformada de ver como as coisas mudaram, e revolta-se por ver que as netas, com uma vida tão confortável quando comparada à sua, não aproveitam as oportunidades e não se preocupam com a família. Nestas horas fica meio "embucetada" com a vida e bebe por alguns dias a fio.

C. Ana, mas você achava ou acha que tinha algum problema com bebida que precisava de ajuda ou não?

A. Ah, quer dizer, eu acho que o meu problema com minha bebida a mim prejudica, eu estou sabendo isto, que só prejudica a mim, os meus filhos a quem convive comigo, prejudico? Prejudico porque eles não gostam, porque minha filha não toma nada de álcool, o meu filho ainda toma, uma cervejinha, quando vai num churrasco com os amigos, mas ele também não é de beber e....

C. Você conversa com alguém sobre isto, Ana?

A. Não, não. A única coisa que às vezes eu falo pra minha prima, é "ah, hoje eu vou entornar todas". Ela fala 'é já percebi'.

C. Tem a ver com o dia que você ta meio brava, será?

A. Que eu começo?

C. É.

A. Ah, tem vez que é assim também...

C. Que você tá meio revoltada com alguma coisa, tá meio brava, assim. Pelo jeitinho que você falou, hoje eu vou entornar todas! É aquele dia que a gente tá meio assim...

A. Embucetada... (ri envergonhada)

C. Tudo bem. Não conhecia este termo.

A. É. (risos)

C. É, mas tem a ver com aquele dia que você tá meio assim brava

A. Aquele dia que você quer, ah, sei lá.

(linhas 985-1005)

Este extrato foi retirado de um momento de nossa conversa em que venho tentando construir com ela explicações para seu consumo de bebidas alcoólicas. Já havia oferecido a ela algumas explicações, baseadas no discurso de consumo de álcool para lidar com o estresse e com o tédio. Ela havia discordado destes discursos e resolvi então perguntar se ela considerava que tinha problema com o consumo de bebidas. Ela utiliza o discurso do direito individual sobre a saúde e posiciona-se como 'Ana que ao beber prejudica apenas a si própria'. Com o uso deste discurso, o consumo de bebidas aparece como um direito que tem de decidir sobre seu próprio corpo. Associa a preocupação dos filhos ao fato destes não beberem. Ao me contar sobre suas conversas com sua prima, ofereço a ela o posicionamento 'Ana que bebe quando está brava', ao que ela a princípio concorda parcialmente. Com isto, ao final deste trecho, 
posiciona-se como 'Ana que bebe quando está embucetada'.

Neste extrato, sua descrição de mulher autônoma e independente, e que, portanto pode decidir o que fazer com sua saúde, conflita-se com o de uma mulher na qual o consumo excessivo de bebidas vem prejudicando a saúde e aborrecendo seus filhos. Em outros momentos de nossa conversa, estes posicionamentos discrepantes vão acompanhar seu relato sobre o tratamento. Durante a entrevista percebemos que Ana não se sente tão à vontade com posicionamentos que the enfraqueçam, construindo uma narrativa empolgada sobre sua história de vida e tornando-se monossilábica quando introduzo o tema "consumo de bebidas". Neste extrato, ela utiliza o discurso do direito individual sobre a saúde para dialogar com as vozes preocupadas dos filhos e utiliza também o discurso da intolerância para dizer que as pessoas criticam o que é diferente, e com isto não legitima as vozes dos filhos que a criticam, mas não bebem.

Este extrato mostra também uma negociação nossa na construção do sentido para o consumo de bebidas, que aparece como forma de linguagem comunicando que ela está brava, revoltada, e quer 'jogar tudo para o ar'.

Quando resolve parar de beber, sente-se meio fraca, triste e fica alguns dias de cama. São os poucos momentos em que pára um pouco, já que tem uma vida super ativa, ocupando-se com mil atividades em casa e na rua. Adora pesquisar preços e aproveitar promoções, chegando a ir diversas vezes por dia no mesmo supermercado. Gosta de jogar bingo em companhia da mãe e da irmã. Em casa, limpa, lava, cozinha e inventa, para não ficar parada. Não consegue nem se sentar para terminar de fumar um cigarro.

C. Só pra gente encerrar então, como é teu dia a dia? Mais ou menos, o que você faz durante o dia?

A. Eu, eu só não fico parada, porque eu não consigo. Eu, é..., tô estranhando que eu tô aqui sentada há tanto tempo.

C. (risos)... sentada, sem tomar água, sem ar condicionado... (risos)

A. Não, eu... É a tal historia, tem a minha cadeirinha lá, na pontinha da minha mesa de cozinha, ali eu sento, acedo um cigarro, ai eu lembro disto, lembro daquilo, eu fumo uns 10,12 cigarros por dia no cinzeiro lá, minhas toalhas de mesa não têm uma inteira, tá tudo furadinha, porque eu acendo o cigarro, 'ah, deixa eu fazer isto'. Então eu vou naquela hora que eu lembro.

C. Aí você deixa o cigarro aceso...

A. Deixo o cigarro aceso... Aí de lá eu faço outra coisa, e quando eu volto ou o cigarro caiu na toalha ou já acabou. E, é ali que eu vou pra lá, vou pra cá, e faço uma coisa, faço outra, eu não sei ficar parada e não sei dizer que se não tem nada pra fazer eu vou deitar, assistir televisão, eu não consigo. Agora ultimamente eu tô deitando um pouquinho porque eu tô muito cansada, então eu faço alguma coisa mais pesada, então já me dá aquele cansaço tudo, então eu preciso parar, dar um tempo pra voltar a fazer.

C. Mas em geral são atividades da casa?

A. Tudo, comida, roupa lavada, passada... 
Este extrato é retirado do final de nossa conversa. Convido-a a me contar sobre sua rotina a fim de tentar obter mais informações que me ajudassem a compreender seu consumo de bebidas alcoólicas. Ela posiciona-se como 'Ana que não consegue ficar parada', 'Ana que trabalha muito em casa' e 'Ana que anda meio cansada'. Estes posicionamentos a constroem, em nossa conversa, como a uma mulher que mesmo depois de ter se aposentado continua ativa e cumprindo suas responsabilidades, entretanto, tendo agora que se adaptar ao fato de sentir-se mais cansada.

Falando em cigarro, gostaria de parar de fumar, teve câncer de mama e acha que este pode prejudicá-la mais. Sempre aproveita as oportunidades em que percebe que pode crescer e com isto, resolveu seguir a sugestão dos filhos e procurar ajuda para diminuir ou parar de beber.

C. E aí, Ana, como é que foi, quando você me conta a tua história com álcool eu fico pensando, como é que foi que você resolveu procurar tratamento, como é que você caiu aqui no serviço do hospital?

A. Ah, é porque os meus filhos ficam muito aborrecidos, né, principalmente quando eu entorno um pouco mais, aí eles brigam comigo, aí eu resolvi vir.

C. $E$ isto acontece em que situações de você entornar um pouco mais?

A. É assim, eu tomo normalmente, tudo bem, só que tem um determinado dia lá que eu excedo, aí eu excedi aquele determinado dia, eu vou uns 2 ou 3 dias excedendo...

C. Você dá uma embalada...

A. Dou uma embalada, isto.

C. Aí no outro dia, você acorda e já bebe de manhã, vai embalando durante o dia...

A. Isto.

C. Até que você para.

A. Aí eu paro, mas eu fico ruim, porque abaixa a resistência, aqueles negócio, fico até de cama, aí meus filhos ficam muito bravos. Mas aí também, a hora que eu decido, não, agora chega, porque tem começar de novo, a vida continua, ai eu levanto, vou pra luta, mas eu fico às vezes uma semana de cama...

C. Depois que você pára de beber, se sentindo como, você fica como?

A. Fico cansada, com sono, quero dormir, dormir, dormir. Mas fico na cama e não durmo.

(linhas 871-889)

C. Exato, tinha que levantar às 4 horas da manhã, não tinha como embalar, né?

A. Não.

C. Então, aqui você não tem este compromisso, então será que isto influencia pra ter estes momentos de pico?

A. Então, porque assim, eu nem programo que hoje eu vou embalar, e nem eu percebo que tem alguma coisa que eu vou, que de repente do nada eu volto a começar a embalar.

C. Você não percebe.

A. Não percebo, nem eu programo aquela embalada.

C. Tá. E assim, quando você disse que você procurou o ambulatório, o tratamento, foi por causa dos teus filhos. O que você imagina que teus filhos pensam do teu relacionamento com BA?

A. Eu não imagino, o que eu sei é que eles brigam comigo. 
C. E aí, quando você procurou o tratamento aqui, você procurou porque eles queriam que você viesse, ou você achava que você tinha algum problema, como é que foi?

A. Na época eu resolvi vir, eu falei "deixa eu ir ver se com ajuda...". Minha filha sempre dizia "procura ajuda, se a senhora não consegue parar sozinha, procura ajuda". Aí acabei ficando sabendo que aqui tinha este grupo de ajuda e aí eu vim.

(linhas 968-984)

C. Ana, e você ficou quanto tempo fazendo tratamento aqui no ambulatório?

A. Ah, pra te falar com certeza mesmo, nem lembro.

C. Mas ficou mais de um ano?

A. Ah, não, foi menos, nem sei se chegou há 6 meses.

C. E neste período que você ficou em tratamento você parou de beber um tempo ou não, como é que foi?

A. Não. Consumindo, tentando diminuir.

C. E você sentiu dificuldade de tentar diminuir.

A. Assim, nem sei se eu consegui diminuir, pra falar a verdade, nem sei.

C. E você acha que você queria diminuir, ou você tava lá porque teus filhos falaram pra você ir, você queria deixar eles felizes ou você sentia que você tava se esforçando porque você queria diminuir mesmo.

A. Não eu vim pra tentar resolver, senão de tudo, um pouco.

C. Você queria diminuir um pouco?

A. Queria, mas...

C. E o que que pode ter te atrapalhado nisto de diminuir, Ana?

A. Não, sei, não entendi também a pergunta.

C. Assim, você falou que veio com a proposta de que você queria diminuir um pouco, mas você falou que acha que nem conseguiu diminuir, então você tinha se proposto uma coisa e você falou, eu acho que não consegui isto direito, o que você acha que te atrapalhou conseguir isto, porque você acha que não conseguiu isto?

A. Ah, não sei te definir o quer foi.

C. E se você pensar assim, no teu relacionamento com bebida, deste jeito seria um sucesso, com seria um sucesso o ter relacionamento com bebida?

A. Como assim?

C. Como você consideraria ideal o teu relacionamento com bebida. Assim, deste jeito eu estaria satisfeita, como seria o ideal?

A. Não tenho a mínima idéia bem, de como seria bom... (entristece)

C. Ta. É difícil falar sobre isto, Ana?

A. Ah, é um pouco (segurando muito pra não chorar)

C. Isto te desperta muita coisa, né?

A. Muita magoa (chorando em silêncio)

(linhas 1009-1040)

No primeiro extrato convido-a a me contar sobre o motivo de sua busca por tratamento para o consumo de bebidas alcoólicas. Ela posiciona-se como 'Ana que cede aos pedidos dos filhos' e como 'Ana que bebe excessivamente por dias seguidos'. Sugiro a ela o posicionamento 'Ana que embala no consumo de bebidas'. Ela aceita e então sugiro 'Ana que pára de beber após dias de consumo excessivo'. Ela então se posiciona 'Ana que se sente mal após consumo excessivo por dias', introduzindo neste momento a voz dos filhos que ficam bravos com ela. Estes posicionamentos olhados isoladamente a construiriam como uma mulher que tem pouco controle sobre o consumo de bebidas e que a quantidade excessiva que 
consome vem lhe causando danos emocionais e físicos, tendo, portanto, problemas com este consumo. Entretanto, continua o relato e posiciona-se como 'Ana que quando decide parar de beber, pára' e como 'Ana que se levanta e vai à luta', construindo-se como uma mulher que tem controle sobre o consumo, que consegue parar de beber quando decide que é preciso e que nestes momentos, retoma sua vida produtiva e ativa. E este conflito de posicionamentos que leva a descrições de si discrepantes continua, quando se posiciona como 'Ana que às vezes fica uma semana de cama depois de passar dias bebendo'.

O segundo extrato segue o momento de nossa conversa em que estamos falando sobre seu consumo atual de bebidas alcoólicas e seu consumo quando morava em São Paulo. O posicionamento resultante de nossa conversa era 'Ana que não excedia em São Paulo porque tinha que ir trabalhar'. Com isto sugiro que a explicação de que talvez ela se permita embalar no consumo de bebidas pois sabe que não tem compromissos no outro dia. Ela se posiciona como 'Ana que não prevê que vai se exceder'. Posiciono-a como 'Ana que procurou tratamento para atender o pedido dos filhos' e ela insere a voz dos filhos, dizendo que eles ficam bravos com ela. Utilizo o discurso psicológico da motivação interna e externa, perguntando se ela procurou tratamento por achar que tinha problema ou para atender o pedido dos filhos. Este discurso considera que mudanças têm mais chances de acontecer quando a pessoa tem uma motivação interna (FONTANELLA, 2000). Ela se posiciona como 'Ana que resolveu fazer uma aposta no tratamento' e insere a voz da filha aconselhando-a a procurar ajuda se não conseguisse parar de beber sozinha. Ao apostar que o tratamento poderá ajudá-la a parar de beber, Ana parece estar construindo seu consumo de bebidas como algo problemático, tendo como importantes colaboradores nesta construção as vozes dos filhos. Constrói-se como uma mulher que se importa por estar incomodando os filhos ao exceder-se no consumo de bebidas e que procura o tratamento para ver com consegue parar de beber. E se neste momento eu tivesse dito a ela que a procura pelo tratamento mostra que ela se preocupa com os filhos. Será que isto legitimaria sua preocupação com os filhos e a busca pelo tratamento? No terceiro extrato conversamos sobre o tratamento realizado para o consumo de bebidas alcoólicas. Como já apontado em outros momentos em que conversamos sobre seu consumo, a narrativa de Ana perde a espontaneidade e nossa conversa torna-se um momento de perguntas e respostas. Ana se posiciona como 'Ana que não quer falar sobre o tratamento' enquanto eu me posiciono como 'Clarissa que quer conversar sobre o tratamento'. Com posições discrepantes, parece que falamos línguas diferentes. No início do extrato Ana se posiciona como 'Ana que ficou pouco tempo em tratamento' e 'Ana que não conseguiu diminuir o consumo'. Com o uso do 
discurso psicológico da motivação interna e externa, que privilegia a motivação interna para a efetividade da mudança de comportamento, ofereço a Ana dois posicionamentos 'Ana que queria diminuir o consumo' e 'Ana que procurou o tratamento para seguir o pedido dos filhos'. Ao oferecer estas posições, crio a dicotomia: interno (esforço para diminuir, desejo real) X externo (agradar os filhos, falta de esforço, sem desejo de mudar). A resposta de Ana me diz que as posições não são tão dicotômicas assim: Ana queria diminuir o consumo para agradar os filhos. A posição de 'Ana que queria diminuir o consumo', em possível diálogo com 'Ana que não conseguiu diminuir o consumo de BA' e com o posicionamento 'Ana que venceu' (posicionamento que tem destaque em nossa conversa) parecem conflitar, trazendo a ela profunda tristeza. Ana constrói-se, em nossa conversa, como uma mulher que passou por dificuldades e venceu, entretanto, ao falar sobre o tratamento, Ana passou por ele e não atingiu os objetivos que tinha se proposto, de diminuir o consumo. Este assunto parece chegar aos seus ouvidos como um convite a posicionar-se como 'Ana que fracassou no tratamento', posicionamento pouco confortável para uma pessoa que se constrói como vencedora. Ana se entristece e chora.

Importante destacar que neste último extrato ajudo a construir seu relato de fracasso com o tratamento. Quando ela me disse que não sabia se tinha ficado 6 meses em tratamento, o modo como fala me convida a desvalorizar sua experiência. Deste modo, nos engajamos em uma conversa onde sua busca e sua experiência de tratamento são construídas de modo negativo, são tratadas sem valor, são olhadas a partir do discurso do déficit. E se eu tivesse respondido: "Que ótimo que você ficou 6 meses no tratamento! Vamos pensar no que aprendeu durante este período." Talvez as construções feitas a partir de então fossem outras. Esta colocação poderia ser um convite para olhar para este período como um momento importante, em que teve ganhos.

Entretanto, ao participar dos grupos, sentia que havia aberto uma porta e entrado por engano. Talvez por não gostar de se expor, talvez por não se identificar com histórias de fracos perdedores, talvez por estar satisfeita com sua cervejinha...

C. Ah, foi em grupo. E você sentiu que você ganhou alguma coisa com isto ou não, teve algum ganho?

A. Ah, ganho eu tive, porque você sempre vê alguma coisa nos outros e tudo, né? Agora com relação a mim não, porque eu nunca nem consegui abrir a boca.

C. Não?

A. Eu tava lá, como alguém que abriu a porta e entrou por engano. Porque ali já tinha os determinados, os que começavam a falar, falar, falar. Os homens começavam a falar sempre a mesma historia: o corno, o que não perdoa, porque a mulher fez isto e aquilo. 
Sempre a mesma historia... E sempre eles que falavam e eu nunca abri a boca, nunca conseguir falar nada, o Dr. Miguel nunca perguntou nada pra mim. Então eu pensei "o que que eu vou fazer aqui, escutar história do corno que não perdoa a mulher porque chifrou ele?". Não, não.

C. Ana, e era um grupo que a maioria era homens ou não?

A. A maioria era homens.

C. E você acha que isto influenciou pras conversas irem sempre pra um lado? Se fosse um grupo de mulheres você acha que poderia ser mais interessante?

A. Olha, eu sou meio radical com as coisas, mas eu vou te falar o que penso.

C. Fala, por favor.

A. Lá aconteceu o mesmo que aconteceu no GRUPO-OUTRO. Grupo, terapia em grupo, os exercícios... só que eu vinha de casa, alegre, satisfeita, saltitante, eu entrava aí e eu saía deprimida. Porque você só via coisa ruim, uma mais escabrosa do que a outra. $\mathrm{E}$ você acaba convivendo só com aquilo ali, só com aquilo ali, quando eu saía daí eu saía chorando, ia pra casa deprimida, ficava deprimida o resto da semana, quando começava a melhorar já tinha que voltar, porque era na segunda feira. Isto porque eu não vinha os dias da semana, nem dois.

C. E o que que te deprimia nos grupos?

A. Ah, sempre a conversa no mesmo sentido, e uma pior que a outra, porque morreu, porque isto, porque aquilo. Tudo bem, a gente tem, só que a gente tem que aprender a conviver, tem que aprender a ter fé em Deus, e tentar tirar de letra, né? Agora vem contar historia da prima, da cunhada, da prima-avó...

C. E você falava isto no grupo Ana?

A. Ah, eu não tinha chance.

C. Porque seria interessante, alguma que trouxesse este ponto de vista diferente.

A. Mas eu não tinha chance.

C. Mesmo no grupo aqui que era com mulheres você não se sentir à vontade pra falar?

A. Não porque o tempo é curto, 30, 40 mulheres, quando uma começava a falar era só aquelas histórias. Cada uma, uma, lógico. Mas era só de amputar, de isto, daquilo, sempre. Nunca vinha pra dizer, "ah, sabe aquela amiga que eu falei que tava? Tá curada, já fez mamografia, não tem mais nada, graças a Deus", era só "Morreu"...

C. Mexia na ferida.

A. Só cutucando a ferida.

C. E no grupo de álcool você achava que era a mesma coisa?

A. A mesma coisa, porque tinha um que contava a história da mulher todo dia, todo dia, e era só ele que falava. Aquele negócio, "agora é a vez de fulano", não. Ele tinha que terminar e quando ele terminava, terminava o horário também.

(linhas 1074-1118)

Neste extrato, começo perguntando a Ana sobre os ganhos que teve com o tratamento ao participar de grupo de psicoeducação para alcoolistas. Ana começa se posicionando como "Ana que teve ganhos ao ver outros com o mesmo problema", mas logo depois posiciona-se como "Ana que não teve ganhos por não poder falar no grupo". Ao usar a metáfora de 'alguém que abriu a porta e entrou por engano', posiciona-se como "Ana que não se sentia pertencendo àquele grupo", explicando que alguns participantes monopolizavam o grupo com suas narrativas, narrativas estas com as quais não se identificava, já que construíam posicionamentos de pessoas vitimizadas e fracas, diferentes dos que busca para si. Influenciada pela literatura sobre tratamento para mulheres usuárias de álcool que defende que grupos só de mulheres têm maior efetividade por estas compartilharem demandas diferentes das 
dos homens (ALLAMANI, 2008; CESAR, 2006), pergunto se seria diferente se o grupo fosse só de mulheres. Ana se posiciona como 'Ana que tem idéias radicais quanto ao tratamento' e avisa que vai dizer o que pensa sobre este assunto. Conta então outra experiência de tratamento, em que participou de um grupo só para mulheres que tiveram câncer e neste momento, posiciona-se como 'Ana que se sentia pior ao participar dos grupos'. Questiona o discurso médico/psicológico de grupo como espaço de ventilação das emoções, que nos diz que uma das funções do grupo é propiciar um espaço para que as pessoas possam falar sobre seus medos, fraquezas e anseios e que ao fazerem isto, sentiriam-se melhor e mais aliviadas (VINOGRADOV; YALON, 1992). Explica que nestes encontros as mulheres narravam apenas histórias tristes, de perdas e fracassos e neste momento posiciona-se como 'Ana que acredita que é preciso aprender a conviver com os problemas', 'Ana que acredita que é preciso aprender a ter fé em Deus', 'Ana que acredita que é preciso tentar superar'. Estes posicionamentos estão relacionados com sua construção como uma pessoa vencedora, como alguém que superou as dificuldades da vida. Mais uma vez ela diz não se identificar com histórias que enfraquecem e vitimizam e, portanto, posicionase novamente como 'Ana que não se sentia pertencendo àquele grupo'.

E se logo no começo deste extrato, quando ela me diz que teve ganhos mas nunca conseguiu falar, eu tivesse perguntado: E que ganhos você teve? Talvez tivesse aberto a possibilidade para construir sua experiência de tratamento como algo positivo.

Não gosta de contar aos familiares sobre os momentos difíceis que viveu, incomodase com a comoção. Ana, despede-se, deixando registrado sua vida de sinceridade, dedicação e amor às coisas em que acredita.

C. Você fuma há quanto tempo?

A. Ah, faz trinta e tantos anos.

C. Trinta e tantos anos. Você fuma quantos cigarros por dia, mais ou menos?

A. Eu tava fumando um maço, mas aí, como o doutor da mama falou pra eu diminuir, já que eu não largava, eu consegui diminuir 6 , tem dia que eu consigo diminuir 10 , mas aí no outro dia eu não consigo diminuir. Tô tentando...

C. Você já pensou em parar alguma vez?

A. Ah, já, cada vez que eu penso em parar eu fumo em dobro, aí o prejuízo é maior ainda (risos)

C. (risos) É que eu pensei no remedinho, você falou que precisava de um remedinho pra parar de beber e pra parar de fumar tem um remedinho...

A. Ah, eu só não usei o adesivo, porque, aquele 'fumasil' aquele chiclete, tem mais um outro, eu já usei todos...

C. Você já usou medicação receitada pelo psiquiatra? Porque estes são de farmácia, agora tem uma medicação que ela age mesmo no cérebro tirando a vontade de fumar...

A. É eu tô sabendo que o hospital tava fazendo mas com os funcionários, só. 
C. É tem uma medicação nova agora, eu não sei o preço dele, mas eu sei que tem uma medicação que age tirando a vontade de fumar, sim.

A. Olha, eu digo, porque parar de fumar eu gostaria sim. Agora eu vou te falar sinceramente, a minha cervejinha eu não gostaria de parar não (risos)

C. Ah, que bom que você falou sinceramente. Agora se você pensar no cigarro e na cerveja, o cigarro você acha que você pára porque te prejudica...

A. Ah, eu acho, porque eu já tive problema de circulação, né, cardiovascular, então eu tenho que procurar um cardio agora, o primeiro tratamento eu fiz aqui, eu quero ver se o postinho me encaminha pra eu remarcar.

C. Agora a cerveja você num vê pra que parar, é isto.

A. Sei lá.

C. Você acha que não tem nada que te causa dano, de repente, como o cigarro? o cigarro, você teve um problema na circulação, você acha que é devido ao cigarro, agora a cerveja...

A. A cerveja é mais o psicológico dos meus filhos, porque pra eles faz mal.

C. Mas pra você, se teus filhos morassem longe, não vissem, pra você, você não vê prejuízo?

A. E lógico que prejudica, a bebida também prejudica, mas pra mim eu não vejo.

C. Você vê mais ganhos?

A. Não, não vejo ganho, porque nada do que é vicio é bom.

C. Mas você falou que a cervejinha você não quer largar.

A. (risos) Mas entre a cerveja e o cigarro eu falei que eu prefiro ficar com a cervejinha, mas se pudesse largar eu largava os dois.

C. (rsrsrs) Mas porque, porque deve ter alguma coisa de bom pra você, de tomar sua cervejinha?

A. Porque é gostoso, relaxa... (manhosa)

C. É isto, então, né, relaxa...

A. (risos)

(linhas 1347-1386)

C. O que é interessante é que a trajetória da tua vida me passa a impressão de uma pessoa que vai aproveitando as oportunidades, você foi conseguindo aproveitar e conseguindo aprender e dar um pulo mais pra frente e conseguindo aprender mais. A escola que pra você sempre foi importante e depois você deu estar prioridade para os teus filhos, você quis colocar eles pra estudar, com a tua neta, até hoje você tá aí pensando que ela tinha que ter estudado. E você conseguiu, você fala "eu mantive boas amizades". E isto se reflete pelos anjos que apareceram na tua vida, porque você contou de alguns anjos que apareceram e te abriram uma outra perspectiva de vida, agora estes anjos apareceram porque você teve este potencial de cativar estas pessoas, de mostrar o teu trabalho, e destas pessoas verem que você tinha potencial pra ir lá e assumir a telefônica, pra ir lá e indicar o teu nome pra uma multinacional, você teve esta força muito forte de ir cativando estas pessoas e mostrando tua capacidade, então me parece, uma reta bem ascendente a tua história.

A. Eu acho que tudo o que a gente se propõe a fazer tem que fazer bem feito e com amor. E eu sempre fiz tudo com muito gosto e com amor. Se eu tiver que lavar um banheiro eu faço com capricho e com amor. Se eu tiver que fazer uma comida, eu faço porque eu gosto de fazer, e vou fazer bem feito porque eu vou gastar o mesmo tempo e as mesmas coisas, o mesmo tempo pra fazer uma porcaria pra ninguém comer e o mesmo tempo, as mesmas coisas, o mesmo dinheiro, pra fazer algo que preste que todo mundo vai comer. Então eu acho que tudo o que a gente fazer tem que fazer bem feito, tem que gostar. 
O primeiro extrato foi retirado do final de nossa conversa. Ana havia me dito que gostaria que tivesse um remédio que tirasse a vontade de beber. Quando me conta que fuma e que gostaria de parar de fumar, digo a ela que há remédios que diminuem a vontade de fumar. Ela então avisa: "Vou falar sinceramente" e posicionase como 'Ana que não quer parar de beber'. Sugiro que seu desejo de parar de fumar e de parar de beber talvez estejam associados aos danos que percebe estarem relacionados ao consumo de cada uma destas substâncias. Aceitando meu convite de pensar sobre isto, ela posiciona-se como 'Ana que teve prejuízos por fumar'. Em relação à $\mathrm{BA}$, ofereço a ela o posicionamento 'Ana que não vê motivos para parar de beber'. Pensando sobre os danos causados pelo consumo de BA, ela aponta posições ambivalentes: 'Ana que gostaria de parar de beber porque prejudica os filhos' e 'Ana que não vê prejuízos para si por beber'. Com o discurso da psicologia comportamental de que a manutenção de um comportamento ocorre devido ao reforço, convido-a a pensar sobre os ganhos que tem ao beber e ela utiliza o discurso de consumo de bebidas alcoólicas enquanto vício, trazendo portanto, prejuízos. Posiciona-se como 'Ana que tem vício por bebidas' e 'Ana que não tem ganhos com um vício'. Continuo insistindo em posicioná-la como 'Ana que tem algum ganho com o consumo de bebidas' e ela, mergulhada no discurso do vício, discurso este que tira o agenciamento pessoal já que a pessoa viciada está subjugada (por determinantes psicológicos, biológicos e sociais) à substância, posiciona-se como 'Ana que se pudesse deixaria de fumar e de beber'. Não aceito o discurso do vício e continuo insistindo no discurso de que a decisão de beber vem do fato deste consumo trazer ganhos. Ela aceita o convite e posiciona-se como 'Ana que bebe porque é gostoso e relaxa'. E se neste extrato eu tivesse feito a seguinte colocação: "Você me diz que gostaria de parar de beber porque se preocupa com seus filhos e percebe que isto os deixa preocupados. Você também me diz que gostaria de parar de beber porque se sente muito triste e fraca quando passa dias bebendo." Será que com isto eu não legitimaria suas descrições relativas à mudança do consumo? Será que com isto eu a convidaria a pensar sobre mudança? Ao insistir na busca dos ganhos, será que convido a construir ganhos?

Durante nossa conversa, Ana é construída como uma mulher que sempre batalhou pelo que quis, com grande agenciamento em relação a sua vida. Quando conversamos sobre o consumo de bebidas, influenciada pelos discursos psicológicos e médicos, de que o consumo é influenciado por fatores genéticos e pelo aprendizado, ela constrói seu consumo como determinado por estes fatores $e$, portanto, perde seu agenciamento, construindo seu consumo como vício, ou seja, algo que não se tem controle, que está acima do desejo. Em diversos momentos insisto em contextualizar 
seu consumo, convidando-a a pensar sobre o que estava acontecendo quando bebia excessivamente e também a pensar sobre os ganhos que tem com o consumo. São momentos em que negociamos discursos diferentes sobre o beber, de um lado o discurso do vício determinado por fatores de risco e do outro lado o discurso do consumo como forma de expressar algo e como forma de obter prazer.

Neste segundo extrato, entendendo que estávamos chegando ao final de nossa conversa, venho propondo uma síntese de nossa conversa. Construo sua narrativa como um drama na qual a heroína sai vencedora. Posiciona-a como 'Ana que aproveitou as oportunidades da vida', 'Ana que sempre procurou crescer', 'Ana que cultivou boas amizades', 'Ana que soube mostrar seu potencial'. Ela utiliza os posicionamentos de 'Ana que faz seu trabalho bem feito' e 'Ana que faz as coisas com amor' para explicar sua história de sucesso. 


\section{Convites feitos a partir da conversa com Ana}

Ana fala sobre diversos eventos tristes e sofridos pelos quais passou. Entretanto, ao deixar a sala após terminar a entrevista, descrevi-a da seguinte maneira: "Esta mulher é uma batalhadora, uma guerreira, uma heroína!". Após ler e reler a entrevista optei por iniciar minha crônica descrevendo-a assim: "...uma personagem de um filme sobre a luta armada brasileira na década de 70, ou uma intelectual feminista falando sobre gênero e poder". Tão diferente de tantos estereótipos e discursos sobre mulheres que recebem um diagnóstico de dependência de álcool.

Desde o início de nossa conversa Ana não quis trazer para o centro da narrativa posicionamentos relacionados ao seu consumo de bebidas alcoólicas. Inicia me perguntado se deve contar sobre toda sua vida ou apenas sobre a parte que diz respeito ao consumo de bebidas, indicando que sua vida vai além deste posicionamento de 'mulher que bebe'. A partir de então podemos observar dois tipos de movimentos durante nossa conversa: relatos longos e empolgados de Ana sobre as dificuldades que teve na vida e o modo como as superou; relatos monossilábicos e desinteressados sobre assuntos relacionados ao consumo de bebidas, sempre atendendo a pedidos meus de falar sobre isto, e dando-me às vezes a impressão de que a conversa a violentava.

Apesar de falar sobre eventos difíceis, o modo como alinhavava estes eventos nos lembra a descrição feita por Gergen (1999) das "sagas heróicas". Para o autor, estas narrativas seguem fases progressivas e regressivas, onde a pessoa descreve dificuldades que teve, acompanhadas por vitórias, seguidas por mais dificuldades e por mais vitórias. Seu pai apostou-a no jogo e perdeu, mas a mãe fugiu com ela e teve apoio dos familiares. Sua avó Ihe dava pinga para beber no sítio quando tinha apenas 5 anos, mas cuidava tão bem dela que se mudou para cidade para lhe colocar na escola. Teve que deixar a escola para trabalhar, mas arrumou namorado e casou-se. Sofreu e apanhou do marido, mas arrumou um emprego em que ganhava muito dinheiro. Divorciou-se e perdeu o emprego, mas mudou-se para São Paulo. E é em São Paulo, quando arrumou o tão sonhado emprego em uma multinacional, que pareceu querer chegar ao fim de seu relato. Gergen (1999) nos fala que uma narrativa, para ganhar inteligibilidade, precisa ter um ponto final, que geralmente é carregado de valor, sendo algo desejado ou indesejado. A impressão que tive em nossa conversa é que Ana gostaria de ter encerrado em seu auge, em seu ponto final, em sua conquista por um posto em uma multinacional. Depois disto, como heroína, ainda cumpriu algumas missões, como ajudar irmã e mãe doentes, dar abrigo ao filho e netas, investir na educação das netas. Lutou outras batalhas, como o diagnóstico de câncer e a reclamação dos filhos pelo modo como bebia. Sendo estas duas últimas batalhas ainda não totalmente vencidas, nossa heroína parece 
não querer falar sobre elas. Esta pode ser uma forma de compreendermos os silêncios de Ana frente às minhas questões sobre o consumo de bebidas.

Em nossa conversa, o tema "consumo de bebidas alcoólicas" apenas aparece de modo espontâneo no início, quando conta que seus familiares bebiam bastante e que the davam pinga com açúcar para beber e adormecer. Este relato é importante, pois, aliado ao discurso do determinismo biológico e ao discurso do aprendizado do comportamento de consumo de álcool desde a infância, constroem seu consumo como algo que foi determinado genética e psicologicamente. Este discurso determinista influenciará depois o posicionamento de 'Ana que tem vício por bebidas alcoólicas', o que a leva a descrever experiências de tristeza, mágoa e de impotência frente ao problema. A história de Ana nos convida a olhar para estes dois discursos tão importantes no campo da psiquiatria e de álcool e outras drogas: o discurso do determinismo biológico e do aprendizado social. Como profissionais da área de saúde mental aprendemos que na realização do exame psiquiátrico é preciso investigar se alguém mais da família já apresentou os mesmos sintomas. Caponi $(2009,2007)$, refletindo sobre o trabalho de Foucault, nos coloca que a medicina, no final do século XIX, começa a estabelecer relações entre lesões no corpo e sintomas, construindo assim diagnósticos diferenciais. Entretanto, não consegue aplicar esta mesma lógica à psiquiatria, já que há uma ausência do corpo. A psiquiatria trabalha, portanto, com a noção de "alongamento do corpo", que se refere à procura de patologias e sintomas similares na família, a fim de comprovar a existência de uma patologia e da hereditariedade desta. Com o mesmo objetivo, a avaliação psiquiátrica também investiga a infância e adolescência. Busca conhecer se no passado a pessoa já apresentava sinais que ajudem a comprovar que o comportamento de hoje é uma doença. Com isto, os discursos do determinismo biológico e do aprendizado social, também são usados para legitimar a busca por sinais que nos indiquem que a pessoa é realmente doente, no caso de Ana, que ela realmente seja dependente de álcool. Entretanto, entendendo a linguagem como prática social, qual a utilidade destas descrições? Compreendendo que os discursos da ciência ajudam a construir discursos do senso comum, através, por exemplo, da mídia e dos profissionais de saúde, quais possibilidades estes discursos nos abrem? No caso de Ana, ganham um tom determinista e parecem querer aprisioná-la enquanto usuária. O discurso dos fatores de risco (genético e psicológico), por um lado tão libertador, ao preconizar que sua identificação precoce torna possível prevenir o aparecimento de uma doença, aparece aqui como sendo enfraquecedor, já que lhe ajuda a construir seu consumo de bebidas como comportamento que teve poderosos determinantes, sendo, portanto, difícil de mudar.

Na narrativa de Ana o trabalho aparece como importante estruturador de sua vida, já que deixou a escola para trabalhar, enfrentou o marido para trabalhar, deixou os filhos e mudou-se de cidade para trabalhar. É também a partir do trabalho que, em 
nossa conversa, constrói-se como vencedora. Teve bons empregos e pode criar os filhos e ajudar a família com seu dinheiro. Como já dito anteriormente, a narrativa de sua vida parece ter fim quando relata a conquista do emprego em uma multinacional onde trabalhou por 14 anos, até aposentar-se.

O consumo de bebidas feito por Ana não aparece como problema durante sua vida, já que ela utiliza discursos e posicionamentos que a constroem como uma mulher de respeito, responsável, trabalhadora e independente. Passa a ser construído como problema nos últimos anos, quando mais velha e aposentada, sob os olhares dos filhos, bebe por alguns dias seguidos. A conversa com Ana nos convida a pensar sobre o contexto social influenciando na construção dos sentidos sobre o consumo de álcool. Ana relata que o consumo feito por sua família diminuiu quando estes mudaram para a cidade. Ela explica que o fato de terem vizinhos próximos os constrangia na hora de beber e de brigarem. Seu consumo também parece regulado pelo meio social. Quando trabalhava, bebia apenas à noite, após o trabalho. Depois de aposentada, sem compromissos no dia seguinte, chega a beber por dias a fio. Se por um lado ela utiliza discursos que falam sobre o determinismo genético e psicológico no consumo de bebidas alcoólicas, por outro lado ela relata importantes mudanças no seu consumo e no de sua família que se deram por fatores sociais. A construção do consumo como um problema também aparece em um determinado momento de sua vida, quando se aposenta e volta a morar perto dos filhos, agora adultos. A voz dos filhos irá ajudar a construir o consumo como problema. Para Zinberg (2009) e MacRae (2009) os controles sociais se dão por sanções sociais e rituais sociais. As sanções sociais seriam normas que definem se uma droga dever ser usada e como isto deve acontecer, incluindo aqui tanto as leis e políticas que regulamentam o consumo, como regras compartilhadas informalmente por pequenos grupos. Já os rituais sociais são padrões de comportamento prescritos ao redor da droga, relacionados com o modo de procurar e selecionar a droga, ao contexto de consumo, às atividades empreendidas após o consumo e aos modos de evitar os efeitos indesejados. Para os autores, os rituais servem para apoiar, reforçar e simbolizar as sanções. No caso de Ana, a substância consumida por ela é considerada uma droga lícita, entretanto, o contexto de seu consumo atual (solitário), a freqüência e quantidade (muitas doses por dias a fio) e o grupo com quem se relaciona (filhos que não bebem), constroem este consumo como algo problemático. Poderíamos aqui também hipotetizar que o fato de ser mulher, ter mais de 60 anos e estar fora do mercado de trabalho também contribuiriam para esta construção. Como vimos anteriormente, mulheres mais velhas que bebem parecem ser mais estigmatizadas e rejeitadas pela família (ETTORRE, 2007; ALLAMANI et al., 2000).

Em nossa conversa, Ana é construída como uma mulher de respeito. Para isto, diz que desde cedo aprendeu a respeitar as figuras de autoridade, como a avó e o noivo. 
Manteve seu casamento por muitos anos, mesmo apanhando do marido. Em relação ao consumo de bebidas alcoólicas, preocupa-se em beber dentro de casa e em não dar vexame. Nos dois momentos importantes em que enfrentou o marido, primeiro ao levar uma surra quando foi visitar a mãe e depois ao aceitar o emprego em posto telefônico, tinha justificativas legítimas para isto, a convivência com a mãe e o sustento dos filhos. Desta forma, nestes momentos, desrespeitar o marido não lhe tirou da posição de mulher de respeito. O discurso dos papéis sociais de gênero é importante em sua construção identitária. Parece que ela passou sua vida negociando posicionamentos que Ihe permitissem ser reconhecida como mulher de respeito e ao mesmo tempo tivesse liberdade para gerenciar sua vida.

Ana é construída também como boa mãe e como uma mulher que cumpria com todas suas obrigações: dona de casa, mãe, filha, trabalhadora, amiga... Diferente do que preconizado por alguns estudos sobre consumo de álcool por mulheres (AMES; REBHUN, 1996), o discurso dos papéis sociais de gênero é utilizado para legitimar seu consumo de bebidas. A bebida ajudava-a a manter seu casamento e seu posicionamento de 'Ana boa esposa' e 'Ana mulher de respeito'.

Ana sempre bebeu, mas foi descrita como dependente há poucos anos. Vemos que o uso problemático não veio associado à quantidade e a freqüência do consumo, mas ganhou este sentido nos seus relacionamentos atuais. Foi no relacionamento com os filhos, agora adultos e abstêmios, que Ana foi posicionada como 'Ana que tem problemas com a bebida'. Este posicionamento foi confirmado quando procurou o tratamento e recebeu o diagnóstico de dependência de álcool.

Valença (2008, p.183) fala sobre o "usuário que consegue sustentar outros papéis sociais sem que o consumo de psicoativos o reduza ao papel e à representação exclusivos de usuário". Na época em que não era posicionada como 'Ana que tem problemas com bebidas', era posicionada como 'boa mãe', 'mulher de respeito', 'batalhadora' e 'trabalhadora'. Podemos pensar que a construção de seu consumo como problema se deu no momento em que "perdeu" contextos e relações que possibilitavam estes outros posicionamentos? Importante ressaltar que mais uma vez os critérios diagnósticos da CID-10 não parecem ter sido os determinantes do diagnóstico de dependência. Será então a dependência algo que está no indivíduo, que pode ser avaliada, prevenida e tratada independente de seu contexto e dos relacionamentos? MacRae (2001), expondo o pensamento de Richard Bucher, nos coloca que as substâncias só se tornam "drogas" e o usuário só se torna "dependente" dentro de um contexto de atividades simbólicas e ambiente.

A conversa com Ana também nos convida a pensar sobre o tratamento oferecido, dentre eles o grupo terapêutico. Ana narra experiências ruins com grupos, por não se identificar com o tipo de relato predominante nestes, relatos saturados pelo problema. 
Diz que participar dos grupos a entristecia e desempoderava. Percebemos que posicionamentos que the enfraquecem são colocados à margem de sua narrativa, portanto, fica fácil de entender porque estes grupos que centralizavam estes posicionamentos eram tão desagradáveis a ela. Os grupos são abordagens muito utilizadas hoje em dia e, muitas vezes, trabalha-se com a idéia de que colocar pessoas com o mesmo diagnóstico juntas será terapêutico. É como se o diagnóstico tivesse o poder de igualar as pessoas. Desta forma, o convite feito aos participantes é falar sobre o que eles têm em comum, ou seja, o diagnóstico: como este vem afetando suas vidas, como viver com ele, como lutar contra ele,... As pessoas se engajam em conversar sobre o problema, construindo descrições de si que muitas vezes as reduzem a 'portadoras de tal diagnóstico'.

Os grupos podem ser importantes espaços para a construção de diferentes significados (RASERA; JAPUR, 2001). A presença de diversas pessoas, que não apenas paciente e terapeuta, pode possibilitar novas vozes e novos discursos (MCNAMEE, 2002). Entretanto, ainda temos muito presente a visão de grupo como espaço catártico, em que a ventilação de emoções ajudaria as pessoas a se sentirem aliviadas e, quando feita em grupo, despertaria a sensação de não estar sozinho em sua dor e de se sentir acolhido por iguais (VINOGRADOV; YALON, 1992). Entretanto, Rasera e Japur (2005, p.33) nos lembra que "o contrato grupal é o meio de delimitar algumas condições de produção de sentido". Desta forma, quando o foco deste é o problema, os discursos e vozes convidados para a conversa estarão construindo o problema ao invés de construir outras narrativas que empoderem e que ajudem a pensar em possibilidades. Ana nos conta que frente ao discurso hegemônico de problema, calava-se. Para os profissionais, talvez fosse resistente, e talvez, o abandono do grupo fosse falta de adesão ao tratamento.

Nossa conversa ajuda a ilustrar este tópico. Quando falamos sobre o tratamento, estamos engajadas em descrevê-lo pelo déficit. Ana começa a descrevê-lo desta maneira e aceito o convite, fazendo colocações que auxiliam na construção da narrativa do tratamento que não funcionou. Se eu tivesse feito outras colocações, que valorizassem o tempo em que freqüentou o serviço e que convidassem a falar sobre os ganhos que teve, talvez a narrativa fosse diferente. Talvez construíssemos esta experiência como algo válido e com isto disponibilizaríamos o posicionamento 'Ana que melhorou depois do tratamento'. Talvez minha voz fosse inserida como uma voz que diz que ela aproveitou o tratamento e com isto, talvez tivesse vontade de voltar ao serviço e reduzir o consumo. Talvez...

A conversa com Ana nos convida a pensar sobre a importância de tratamentos e conversas que investiguem a fundo o problema, que busquem suas causas, que incentivem a ventilação da emoção, que se baseiem em teorias de que falar sobre o problema ajuda a resolvê-lo. Ana nos diz que em sua experiência, falar sobre o problema 
ajuda a criá-lo. Ela nos conta que chegava aos grupos sentindo-se feliz e após ouvir relatos sofridos sobre a doença, deixava os grupos sentindo-se fraca e triste. Profissionais que utilizam o discurso psicanalítico poderiam dizer que Ana negava entrar em contato com seu sofrimento e que não aderiu ao tratamento por ser resistente em relação à mudança. Mas Ana nos convida a olhar sob outra perspectiva: não é preciso falar sobre o problema, é preciso aprender a conviver com ele, aprender a ter fé em Deus, aprender a 'tirar de letra'. Se o tratamento tivesse como foco a solução do problema ou a construção de narrativas que a empoderasse, talvez tivesse sido mais interessante para Ana. Se o tratamento valorizasse posicionamentos que a construísse como vencedora, ou pelo menos, que a reconhecesse como heroína, talvez tivesse sido mais interessante.

Nossa conversa também nos convida a olhar para discursos utilizados em saúde, como o da adesão ao tratamento. De posse deste discurso diríamos que Ana não aderiu ao tratamento, trazendo implícito aqui uma visão de paciente que não segue as recomendações dos profissionais de saúde que sabem o que é melhor para ela, sendo, portanto, uma paciente negligente. O discurso da adesão ao tratamento desconsidera outras construções feitas pelas pessoas, valorizando apenas o saber do profissional "expert". Está ancorado ao discurso da medicalização. O profissional, ao fazer uso deste discurso, corre o risco de rotular o paciente ('resistente', 'aquele que não adere ao tratamento') e culpabilizá-lo por não seguir suas orientações, ao invés de manter uma postura curiosa, querendo conhecer quais construções a pessoa vem fazendo ao redor deste tema e quais os motivos que a leva a não seguir determinadas orientações. É um discurso que coloca "um ponto final" na conversa ("Ele não aderiu ao tratamento.") ou que convida a repetição da mesma orientação ("Vamos falar novamente e ver se conseguimos convencê-lo"). O discurso da adesão ao tratamento considera que apenas o profissional é o 'especialista', não valorizando que o paciente é o 'especialista' em sua vida (CAMARGO-BORGES; MISHIMA; MCNAMEE, 2009). Pode levar a uma postura autoritária e desrespeitosa por parte do profissional, que ao invés de manter o diálogo, afasta-o do paciente.

Ana nos diz que aderir ao tratamento significava passar uma hora por semana ouvindo histórias tristes e voltar para casa sentindo-se vitimizada e fraca, precisando de uma semana para se recompor, quando novamente iria ficar por uma hora ouvindo outras histórias tristes. Este mesmo convite, de olhar com atenção para o discurso de adesão ao tratamento, foi feito por Camargo-Borges e Japur (2008). No trabalho destas autoras, usuárias de um serviço de atenção primária relatam não tomar os medicamentos prescritos por médicos quando entendem que não foram bem examinadas ou que a prescrição não foi correta. As autoras sugerem que a não adesão ao tratamento pode ser considerada nestes casos como auto-cuidado, de pacientes protegendo-se de 
uma não escuta médica, de exames mal realizados e de prescrição mal feita. Em nosso estudo, ao não aderir ao tratamento, Ana protege-se de ser posicionada como 'vítima de uma doença', 'alguém com poucas esperanças', 'mulher frágil', posicionamentos estes que a enfraquece e não despertam mudanças.

Entendendo a terapia como uma prática de conversação dialógica, esta será terapêutica quando proporcionar a construção de novos significados. Assim, o terapeuta deve buscar nos relatos histórias que mostrem recursos, habilidades e competências, compreendendo que as histórias que não são contadas, deixam de existir (GRANDESSO, 2000). Em nossa conversa, Ana encontrou a oportunidade de contar suas histórias de sofrimento e de como sobreviveu e venceu. Entretanto, descreve que em suas experiências de tratamento, não encontrava oportunidades para este relato.

Ana termina a conversa dizendo que gostaria de parar de fumar, mas não gostaria de deixar de beber. Valença (2008) nos lembra que muito antes do uso de álcool e drogas ser considerado como expressão do sofrimento humano, era considerado como busca da transcendência. Atualmente, existe contexto discursivo que possibilite que o consumo de bebidas de Ana não seja considerado problema? Frente à hegemonia do discurso médico e do discurso de prevenção de riscos, aliados aqui ao discurso dos papéis sociais de gênero, há espaço para não construir este consumo como problemático? Quais vozes e discursos poderiam fazer coro a esta voz de Ana? Ana nos diz que bebe quando esta 'embucetada'. Etorre (1997) nos lembra que vivemos em uma sociedade que busca controlar as emoções e a consumir as mais diversas substâncias para conquistar tal desejo. Entretanto, em uma sociedade medicalizada, são os profissionais quem sabem quais substâncias podem ser consumidas para aliviar a dor. E se Ana passasse uns três dias dormindo devido a um tratamento que receitasse ansiolíticos? Seria um problema? Ficaria depois mais um dia de cama, sentindo-se envergonhada? Seria criticada pelos filhos? Seria encaminhada ao médico? Ou estaria só cumprindo recomendações médicas?

O discurso da medicalização vem destruindo nossos recursos para lidar com a dor e com o sofrimento. Vem destruindo recursos culturais que ajudavam a lidar com as diversas experiências, a dar sentido a elas, a dar apoio a quem as vivenciava (TESSER, 2006). Diz que é preciso profissionais de saúde para auxiliar a viver. Ana nos diz que não. Que é preciso ter fé, é preciso saber conviver com a dor, é preciso tirar de letra. 



\section{Convite para construir outra versão para a história de Ana}

Ana,

Acabo de fazer diversas leituras sobre nossa conversa. A cada leitura, aumenta minha impressão de que você é uma mulher vitoriosa e com muita coisa para ensinar aos outros.

Ao me contar sobre sua história de vida, fico com a impressão de que você foi muito amada e protegida por sua família. Quando bebê, sua mãe fugiu de casa com você por medo de te perder e, na época, foi acolhida por sua avó e tios. Sua família compreendeu que você, por ser criança, precisava de proteção. Como tinham momentos de desentendimento, queriam te poupar de ter que assistir brigas e gritarias e então, colocavam-Ihe para dormir. Quando sua avó Ihe dava pinga com açúcar ela estava Ihe protegendo de ter que assistir às brigas e com isto, estava demonstrando que te amava e se preocupava com você. Você parece ter sido sempre muito amada por eles. Sua mãe e avó se mudaram para a cidade com o objetivo de te colocar na escola, entendendo que isto te daria um futuro melhor. Em sua história de vida, sua avó e mãe estiveram sempre ao seu lado, mesmo que isto significasse ir contra as expectativas da sociedade. Ao ver que você sofria ao lado do seu ex-marido, sua avó chegou a sugerir que você o abandonasse e fosse morar com ela. Em outros momentos, ela ofereceu sua casa para você ir morar com sua família, tudo para que pudesse ficar mais perto de você e para que pudesse te ver mais feliz. Foi também sua avó, que por amá-la tanto e por confiar em seu potencial, incentivou que você aceitasse o emprego no posto telefônico da cidade e, com isto, garantisse o sustento de sua família e sua independência financeira. Você me conta que teve uma família muito boa, que cumpriu com o que é esperado que uma família faça: proteja seus membros e os incentive a crescer.

Com este apoio, você deslanchou na vida! Aproveitou cada oportunidade que the foi dada. E mostrou ser muito inteligente desde criança. Quando sua avó plantava verduras, você percebeu que aquela era uma oportunidade de vocês ganharem algum dinheiro e pediu a ela se poderia vender as verduras. E então você me diz, que guardava o dinheiro que ganhava pois queria comprar uma máquina de costura. Mostra que desde criança era muito esperta, tinha noção de que era preciso criar oportunidades para ganhar dinheiro e que era preciso economizar para conquistar as coisas que desejava.

Foi também muito inteligente e corajosa quando aceitou o emprego no posto telefônico. Mesmo tendo que enfrentar seu ex-marido, você olhava para o futuro e sabia que este emprego iria garantir melhores condições de vida para você e para seus filhos. Também enfrentou seus medos, quando teve que deixar a vida em uma pequena cidade do interior para tentar a sorte na cidade grande. Foi para São Paulo cheia de esperanças 
e coragem e mostrou sua seriedade e responsabilidade em cada emprego que teve, conseguindo com isto, o trabalho que tanto desejava.

Você me parece uma mulher que sempre esteve à frente de sua época. Sua vida é a vida de uma mulher independente e autônoma. No entanto, mesmo sendo diferente das mulheres que aceitavam tudo passivamente, você sempre se colocou como uma mulher de respeito. Sempre conseguiu cumprir com suas responsabilidades de dona de casa, de mãe, de filha e de trabalhadora.

Com isto, conquistou a confiança das pessoas. Em sua história, percebo que inúmeras vezes você teve apoio de amigos que enxergavam seu potencial, confiavam em sua responsabilidade e, portanto, Ihe davam oportunidades de crescer.

Sempre gostou de ser útil aos outros e ao mudar-se para Ribeirão Preto, pode ajudar sua mãe, sua irmã, seus filhos e netos. Você mostra que se preocupa tanto com o bem estar de seus familiares que, às vezes, deixa de fazer as coisas que gosta para vêlos felizes. Por se preocupar com seus filhos, procurou um serviço para conversar sobre o modo como vinha consumindo bebidas alcoólicas e concordou em freqüentá-lo por 6 meses. Você me disse que procura aprender com todas as experiências e fiquei imaginando o que você deve ter aprendido com esta vivência.

Ao invés de se apegar ao passado, você olha para o futuro. Ao invés de ficar reclamando e falando sobre as coisas que não deram certo, você prefere lutar e ter fé em Deus. Agradeço por ter compartilhado um pouco de sua vida comigo. A forma positiva como você encara as situações e a postura de guerreira com que enfrenta as adversidades, podem ser lições de vida para todos aqueles que te conhecem. 
Capítulo 7

Discursos e histórias 

Trabalhando no campo de estudo de álcool e outras drogas, campo que nos últimos anos vem sendo construído de modo a despertar preocupação aos diversos atores sociais (como mídia, políticos, profissionais de saúde, educadores, assistentes sociais, religiosos, polícia e população geral), convivo com os diversos discursos que constroem este campo. Apesar de serem diversos, percebo que muitos destes têm efeitos em comum, que auxiliam a construir nosso objeto de estudo com algumas características que, por estarem presentes em diferentes discursos, são tomadas como "verdades". Tratarei a seguir de três destes discursos.

Primeiramente, o discurso que trata sobre a legalidade das drogas, classificandoas como lícitas e ilícitas. Constrói todo e qualquer consumo de substâncias ilícitas como um problema e estabelece critérios para o consumo de substâncias lícitas. Um dos efeitos desta classificação é a construção de que as drogas ilícitas causam prejuízos enquanto as lícitas não.

Outro discurso que vem se tornando hegemônico, é o discurso de que determinado consumo é considerado dependência e de que isto é uma doença. Este discurso cresce na medida em que cresce o discurso da medicalização. Ele nos convida a olharmos para algumas pessoas como portadoras desta doença, como se a dependência fosse um mal que estivesse dentro delas e que precisasse ser tratada e curada.

O terceiro discurso divide as drogas entre recreativas e medicamentosas. De acordo com este discurso, todas as substâncias que agem no sistema nervoso central, alterando funções cerebrais e mudando temporariamente a percepção, o humor, a consciência e o comportamento são substâncias psicoativas. Entretanto, algumas destas são consideradas seguras e contribuindo para a saúde, sendo recomendadas por médicos, enquanto outras são vistas como potenciais causadoras de problemas, devendo ter seu consumo prevenido. Vale lembrar que esta divisão também está ancorada no discurso da medicalização, que traz para as mãos do profissional "expert" o controle sobre o uso de substâncias psicoativas. Deste modo, o consumo que causa preocupações é aquele que não é regulado pela figura do profissional. Um dos efeitos deste discurso é a crença de que drogas recomendadas por médicos não levam a conseqüências danosas, enquanto as outras levarão certamente. Este discurso também constrói o usuário de substâncias não prescritas por um profissional como alguém que se expõe a riscos e com possíveis dificuldades para regular seu comportamento.

O convite feito neste estudo para nomear as descrições utilizadas no campo de álcool e outras drogas como "discursos", visa a não naturalização destas. O discurso construcionista social nos convida a olhar para estas "verdades" e problematizá-las, desconstruí-las. Convida-nos a compreender estas descrições como construções realizadas em determinando momento histórico e cultural, sustentadas por outros discursos presentes neste momento, e produzindo efeitos diversos. Convida-nos a olhar 
para estas não como representações de algo que existe, mas como construtoras de realidades e a assumir uma postura crítica acerca destas realidades construídas, ponderando eticamente sobre elas. As classificações de drogas lícitas e ilícitas constroem uma realidade onde a freqüência de consumo de drogas lícitas é maior do que as de ilícitas (por serem de mais fácil acesso, divulgadas pela mídia, entendidas como substâncias "mais fracas"), a tolerância em relação ao consumo das drogas lícitas é maior do que em relação às ilícitas e o usuário de drogas ilícitas é tratado com maior estigma do que o de drogas lícitas. Estes não são dados da realidade representados pelo discurso e sim efeitos deste discurso.

O discurso da dependência enquanto doença também produz efeitos. Parece aumentar a tolerância social em relação a certos comportamentos, que passam a ser entendidos como doença e não como caráter. Também convida as pessoas a buscarem ajuda em serviços de saúde para mudar estes comportamentos e treina profissionais para lidarem com estas pessoas. Outro efeito deste discurso é a cristalização de descrições de si a partir da "doença", enfraquecendo possibilidades de mudança. Pode também convidar a descrever a pessoa que recebeu este diagnóstico como alguém com poucos recursos, estando passivamente submetido à dependência/doença. Percebe-se que o mesmo discurso pode levar a diferentes efeitos e práticas.

A fim de legitimar o status de "doença", muito dinheiro e recursos são investidos em pesquisas que auxiliam a construir esta descrição. Deste modo temos vasta literatura na área, auxiliando na construção do entendimento de que a dependência é uma doença. Se a mesma quantidade de dinheiro e recursos fosse investida a fim de comprovar que a dependência é um modo de vida, será que não teríamos vasta literatura que comprovasse esta descrição? Quais seriam os efeitos do discurso da dependência como modo de vida? E se fosse investido o mesmo dinheiro e recursos para comprovar que este comportamento de consumo de substâncias significa maior aproximação a forças superiores? O leitor deve estar pensando: "Agora ela foi longe demais, isto é impossível". Este exemplo nos mostra que não temos total liberdade para construirmos realidades. Cada novo discurso precisa estar ancorado em outros já utilizados para ser legitimado. Podemos compreender o consumo como aproximação a forças superiores quando olhamos para alguns grupos, como por exemplo, populações indígenas. Temos presentes outros discursos que dão legitimidade para esta construção (população indígena tem outras práticas religiosas, população indígena não é regulada pelos mesmos valores que não-indígenas, população indígena deve manter suas tradições, população indígena é exótica, dentre outros). Entretanto, Ana e Miriam não tinham outros discursos que legitimassem o consumo de bebidas alcoólicas feito por elas. Mirian tenta utilizar o discurso do consumo pelo prazer, mas este não legitima seu comportamento. Ana tenta usar o discurso do direito sobre seu corpo, mas este se enfraquece frente ao discurso da 
maternidade (mães não devem trazer sofrimento aos filhos). Não conseguem legitimar o consumo e são classificadas como dependentes. Talvez por não terem companheiro, talvez por terem mais que 50 anos, talvez por serem de classe média baixa, talvez por beberem sozinhas, talvez por serem mulheres. Será que se Miriam fosse homem teria sido também considerada dependente? Teria sido encaminhada para tratamento? Será que se fosse homem, sua família colaboraria mais? Teria que comprar bebidas cada dia em um lugar diferente? Ouviria críticas do dono do bar porque bebe todo dia? E se Ana fosse mais jovem? Será que se culparia por beber por alguns dias a fio? E se não tivesse filhos? Será que teria procurado um serviço para tratamento?

O consumo de bebidas alcoólicas de nossas colaboradoras não foi sempre construído como problemático. Ana nos diz que quando trabalhava, não considerava como problema o modo como bebia. Miriam nos diz que bebeu com a irmã em diversas situações quando viajaram juntas, entretanto, este consumo também não foi criticado ou considerado desvio. Tanto Ana quanto Miriam cumprem com suas responsabilidades e conseguem manter diversos outros posicionamentos que não os de 'dependentes'. A construção de sentidos de consumo como dependência parece ter se dado de modo diferente do preconizado pelo discurso do senso comum, de que dependente é quem bebe todos os dias (Ana passa dias sem beber), dependente é quem dá vexame (as duas bebem discretamente) e dependente é quem não cumpre suas responsabilidades devido ao consumo (as duas cumprem todas suas atividades e compromissos). O incômodo pelo consumo parece ter sido construído nas relações, de Ana com os filhos que não bebem, ou na falta delas, de Miriam bebendo sozinha em sua casa.

Neste estudo, considerou-se que a importância de desconstruir alguns termos e conceitos utilizados no campo de álcool e outras drogas e nomeá-los como discursos se dá com o intuito de abrir a possibilidade para que façamos uso destes de modo generativo. Se considerarmos que os discursos têm efeitos e produzem realidades, podemos utilizar nas diversas situações os discursos que nos parecem mais generativos. Quais discursos facilitam nosso diálogo com o público leigo? Quais discursos facilitam nosso diálogo com profissionais de saúde? Quais discursos nos aproximam dos usuários? Quais discursos nos possibilitam construir uma relação de ajuda? Quais discursos nos permitem construir uma realidade que possa sustentar a construção do uso abusivo como um problema sem colocar o usuário em uma posição passiva ou submissa? Quais discursos nos permitem construir o problema do uso do álcool sem cristalizar uma descrição do usuário como alguém fraco, moralmente reprovável, passivo e/ou psicologicamente perturbado?

Este é um desafio, mesmo porque, como visto anteriormente, os mesmos discursos produzem diferentes efeitos. É com o seu uso, nos relacionamentos, que estes efeitos ganham contorno. Podemos imaginar, com o uso de experiências prévias, quais 
serão os efeitos, mas podemos também nos surpreender com o sentido que estes ganham em determinada conversa. É preciso, portanto, dar atenção ao que ocorre nas relações, para que possamos utilizar os diversos discursos de modo responsivo e flexível, buscando manter o diálogo como nossos interlocutores.

Para nos auxiliar neste desafio, podemos lançar mão da reflexividade: quais são os discursos que utilizamos dentro deste campo? Quais são os possíveis efeitos destes? Que realidade gostaríamos de ajudar a construir? Como podemos utilizar os diferentes discursos para nos engajarmos nesta construção? Quais discursos nos ajudam a diminuir o preconceito frente a este tema? Podemos utilizar outras vozes e outros discursos para expandir as possibilidades de construção de sentido para este campo? Podemos utilizar outras vozes e outros discursos para nos engajarmos no diálogo com nossos interlocutores (usuários, profissionais, mídia)? Podemos nos engajar na construção de diferentes histórias, buscando outros efeitos e possibilidades?

Em relação ao consumo de bebidas alcoólicas por mulheres, vimos que a literatura apresenta uma riqueza de discursos para a construção deste objeto. Destacamos aqui alguns efeitos dos discursos epidemiológico, biomédico, psicológico, social e de gênero. Este último foi utilizado no diálogo com todos os outros. Um dos efeitos produzidos por este diálogo é a compreensão de que o discurso dos papéis sociais de gênero teria efeitos que influenciariam na construção dos outros discursos. Deste modo, os números da epidemiologia seriam menores para mulheres, que bebem menos devido ao discurso dos papéis sociais de gênero, mas que também teriam mais medo de responder afirmativamente a questões sobre o consumo, devido ao mesmo discurso. As descrições da literatura biomédica também poderiam ser influenciadas pelo discurso de gênero, já que os pesquisadores compartilham de contextos culturais onde este discurso é forte e tradicional. Além disto, este discurso poderia construir a realidade de saúde mais frágil de muitas mulheres, que diferentemente de grande parte dos homens, não têm com quem contar em momentos em que consomem bebidas alcoólicas de modo considerado problemático. O discurso sociológico trabalha de mãos dadas com o discurso de gênero, utilizando-o para justificar as razões das mulheres beberem menos, de serem mais estigmatizadas e de começarem ou não a beber. Um dos efeitos deste discurso é a construção do consumo de bebidas alcoólicas como um passo em direção a igualdade de gêneros ou a emancipação da mulher. A mulher ficaria dependente (de bebidas) ao lutar por ficar independente (de homens)? O discurso psicológico internaliza algumas descrições que podem ocorrer como efeitos do discurso dos papéis sociais de gênero, como auto-imagem negativa, autocrítica elevada, percepção de fraqueza e sentimentos de inadequação. Este discurso nos convida a colocar dentro da mulher, e compreender como sendo parte de sua personalidade, descrições que podem ser efeitos do discurso de 
gênero. Com isto, constrói "personalidades de mulheres dependentes", naturalizando a dependência e colocando-a como parte da constituição da mulher.

Parece-nos então, que para compreendermos de modo diferente o consumo de bebidas alcoólicas feito por mulheres, é importante compreender os efeitos do discurso dos papéis sociais de gênero sobre a mulher e sobre o consumo. Na conversa com as colaboradoras, o discurso dos papéis sociais de gênero também teve importância na construção do consumo. Miriam é construída como uma mulher que fracassou em relação a este discurso, já que não casou ou teve filhos, e o consumo de bebidas pode ser construído como uma conseqüência deste fracasso. O consumo de Ana foi construído como tendo iniciado a fim de ajudá-la a cumprir com o que é esperado pelo discurso dos papéis sociais de gênero, de que a mulher permaneça casada e obediente ao marido.

Com isto, percebemos o quanto este discurso é importante na construção do significado do consumo de bebidas por mulheres. Conhecer as construções realizadas com o uso deste discurso parece ser importante para subsidiar trabalhos preventivos neste campo e para construir uma relação de ajuda com as mulheres que se sentem oprimidas frente às construções de sentido organizadas ao redor do consumo de bebidas alcoólicas.

Este material também ilustra como construímos sentidos sobre o mundo e sobre nós mesmos nos relacionamentos com outras pessoas. Com o relato de nossa conversa, pode-se observar o processo de construção de sentidos sobre a vida, o consumo de bebidas alcoólicas e o tratamento. A história de vida construída ao final de nossa conversa foi pintada a quatro mãos. Na conversa com Ana, talvez motivada pelo convite feito por sua postura, que corporificava a descrição de uma pessoa segura e forte, eu me engajei em ajudá-la a construir uma narrativa de sucesso. Queria que ela deixasse a entrevista sentindo-se ainda mais forte, independente do consumir ou não bebidas. Ela se posicionou como alguém que não tinha problemas com a bebida e eu aceitei este posicionamento. Frente a suas indicações de que não gostaria de conversar sobre temas que the enfraqueciam, respeitei e busquei outras conversas. Aceitei o convite de falar sobre seus sucessos e fiz questão de verbalizar os recursos que vinha usando para conquistá-los. Construímos uma narrativa de sucesso. Diferente de Ana, a postura de Miriam corporificava a descrição de uma pessoa frágil e amedrontada. Aceitei este convite e não me engajei com ela na construção de uma narrativa de sucesso. Em diversos momentos trouxe vozes de autores da literatura de álcool e outras drogas, que me inspiraram a fazer determinadas perguntas, posicionar-me com frustração diante de respostas e oferecer alternativas para seu sofrimento. Miriam também trouxe diversas vozes, como a da irmã e a do dono do bar que criticaram seu consumo e a de médicos que ajudaram a construir um sentido para as razões de seu sofrimento e para seu tratamento. Durante a entrevista, aceitei o convite de Miriam na construção de uma 
narrativa de problema. Algumas vezes tentei empoderá-la e, para isto, fiz coro às vozes dos outros profissionais, dizendo que ela se beneficiaria em voltar para a terapia e em realizar outras atividades sozinha. Nestes momentos, assumi uma postura diretiva, prescritiva e não responsiva, ajudando a construir mais sofrimento. Queria que ela deixasse a entrevista, sentindo-se mais motivada a retornar ao tratamento e a realizar outras atividades.

Em nossos relacionamentos somos co-responsáveis pelos sentidos construídos. Aqui, aceito o convite do discurso construcionista social para o exercício da reflexividade. Em diversos momentos da análise de nossa conversa, fiz a pergunta: "E se eu tivesse falado essa outra coisa? Qual teria sido o 'rumo' de nossa conversa?" O leitor também é convidado a fazer este exercício, com os extratos de minhas entrevistas, ou de entrevistas pessoais, ou de entrevistas de terceiros, ou material clínico ou com outro material que possibilite esta reflexão. Verá como abrimos e fechamos possibilidades com as colocações que fazemos em uma conversa, com os discursos que utilizamos e com os posicionamentos que disponibilizamos.

Esta reflexão nos convida ao engajamento relacional. Em uma relação, com um paciente, por exemplo, não somos mais o 'terapeuta que diagnostica e identifica as características de personalidade do paciente', mas somos figuras importantes na coconstrução de seu problema de saúde, de seu projeto de vida e de sua descrição de si. Diferentes histórias podem ser narradas sobre as pessoas. A história de Miriam foi descrita aqui como "saturada pelo problema". Entretanto, identificamos em seu relato diversas situações que poderiam ser consideradas exceções, por indicarem vida além do problema. Iremos continuar ajudando a construir histórias que apenas listem problemas, déficits e necessidades e constroem pessoas frágeis e doentes, ou podemos começar a listar também os recursos, sucessos e sonhos, e assim construir pessoas com desejos e com potenciais? Quais descrições/histórias nos aproximam, nos auxiliam a manter o diálogo e a estar engajados em uma relação de ajuda?

O discurso construcionista social nos convida a estar atentos ao que acontece quando nos relacionamos. Temos diversas teorias que sustentam técnicas já muito utilizadas na área, como a entrevista motivacional, intervenções breves, prevenção de recaídas, redução de danos, dentre outras, entretanto, o uso destas técnicas não deve estar acima da relação. A postura de flexibilidade do terapeuta para o manejo destes recursos parece importante, a fim de construir com o cliente uma relação de ajuda.

É importante também questionarmos a utilidade do discurso do diagnóstico psiquiátrico. Quais vêm sendo seus efeitos? Ele está ajudando a nos aproximarmos, a ouvirmos, a construirmos possibilidades ou está apenas trazendo um entendimento pronto, baseado em descrições e histórias contadas pelas classificações diagnósticas? 
Será que a história produzida pelo terapeuta ou por determinada teoria é mais importante do que a história produzida pelo paciente?

Deste modo, o discurso construcionista nos convida a compreendermos que para todas as coisas, há diferentes histórias a serem contadas. A história do diagnóstico é uma delas, a história da psicanálise é outra, a história da motivação para mudança é outra, a história da religião é outra, a história do paciente é outra e a história produzida pelo terapeuta é outra. Não existe uma história que seja mais verdadeira que a outra, todos os discursos são modos de contar uma história. Estes discursos serão mais ou menos válidos de acordo com o uso feito nas relações. São úteis na medida em que abrem espaço para mudanças, para fortalecer o paciente e para pensar em outras possibilidades.

Deste modo, valoriza-se a flexibilidade e a responsividade, considerando que devemos manter o diálogo aberto e contínuo com os diferentes atores sociais, em uma postura ética e engajada, de co-responsabilização.

Este estudo apresentou diversos discursos que constroem sentidos sobre o consumo de bebidas alcoólicas por mulheres, assim como também contou diferentes histórias sobre mulheres que fizeram tratamento devido ao modo como bebiam. São discursos que constroem histórias e histórias recheadas por discursos. Neste entrelace de histórias e discursos, estamos todos envolvidos, construindo modos de ser e de viver. 

Referências 

ALLAMANI, A. Alcoholic Beverages, Gender and European Cultures. Substance Use \& Misuse, v. 43, n.8/9, p. 1088-97, 2008.

. et al. Drinking cultures and the position of women in Europe. Substance Abuse, v. 21, n.4, p. 231-247, 2000.

ALLEN, D. Are Alcoholic women more likely to drink premenstrually? Alcohol \& Alcoholism, v. 31. n. 2, p. 145-147. 1996

AMES, G.; REBHUN, L.A. Women, alcohol and work: interactions of gender, ethnicity and occupational culture. Soc Sci Med, v. 43, n.11, p. 1649-1663, 1996.

AUBRY, C.; GAY, M.C.; ROMO, L.; JOFFRE, S. The alcoholic's self-image: a comparative study between men and women. Encephale, v.30, n.1, p. 24-31, jan/feb 2004.

AVDI, E. Negotiating a pathological identity in the clinical dialogue: Discourse analysis of a family therapy. Psychology and Psychotherapy: Theory, Research and Practice, v.78, 493-511, 2005.

AYRES, J.R.C.M. O cuidado, os modos de ser (do) humano e as práticas de saúde. Saúde e sociedade, v.13, n.3,p.16-29, 2004.

.Norma e formação: horizontes filosóficos para as práticas de avaliação no contexto da promoção da saúde. Ciênc. saúde coletiva, v.9, n.3, pp. 583-592, 2004.

BABOR, T.F.; HIGGINS-BIDDLE, J.C.; SAUNDERS, J.B.; MONTEIRO, M.G. AUDIT: teste para identificação de problemas relacionados ao uso de álcool: roteiro para uso em atenção primária. Tradução de Clarissa Mendonça Corradi. Ribeirão Preto: PAI-PAD, 2003.

BATISTA， S.R.; CORRADI-WEBSTER, C.M.; FIGUEIREDO, M.S.L.; FURTADO,E.F. Cuidados en salud mental hacia adolescentes. In: Congreso Internacional de Psicoeducación, 2006, Chile. Anais do Congreso Internacional de Psicoeducación. v. 1. p. 1-2.

BLOOMFIELD, K.; GMEL, G.; WILSNACK, S. Gender, Culture and Alcohol Problems: a Multi-national Study. Alcohol and Alcoholism, v.41, n.1, p.3-7, oct/nov 2006.

BOURDIEU P. L'illusion biographique. Actes de la Recherche en Sciences Sociales, v. 62/63, p. 69-72, 1986.

BOURGOIS, F. Disciplining addictions: the bio-politics of methadone and heroin in the United States. Culture, Medicine and Psychiatry, v. 24. p. 165-195, 2000. 
BRASILIANO, S.; HOCHGRAF, P.B. Drogadição feminina: a experiência de um percurso. In: SILVEIRA, D.X.; MOREIRA, F.G. Panorama atual de drogas e dependências. São Paulo: Ed. Atheneu, 2006, p. 289-95.

BURR, V. Social constructionism. 2a Edição. New York: Routledge, 2003, 225p.

CAMARGO-BORGES, C.; JAPUR, M. Sobre a (não) adesão ao tratamento: ampliando sentidos do autocuidado. Texto Contexto Enferm, v.17, n.1, p. 64-71, 2008

CAMARGO-BORGES, C.; MISHIMA, S.; MCNAMEE, S. Da autonomia à responsabilidade relacional: explorando novas inteligibilidades para as práticas de saúde. Gerais: Revista Interinstitucional de Psicologia, v. 1, n.1, p. 8-19, 2009.

CASTIEL, L.C.; DIAZ, C.A.D. A saúde persecutória: os limites da responsabilidade. Rio de Janeiro: Ed. Fiocruz, 2007.

.; GUILAM, M.C.R. A saúde persecutória: à espera dos riscômetros portáteis. Interface - Comunic, Saúde, Educ, v.11, n.21, p.145-63, 2007.

$461-466,2007$.

; DARDET, C.A. La salud persecutoria. Rev. Saúde Pública, v.41, no.3, p.

CAPONI, S. Michel Foucault e a persistência do poder psiquiátrico. Ciência \& Saúde Coletiva, v. 14, n.1, p.95-103, 2009.

Da herança à localização cerebral: sobre o determinismo biológico de condutas indesejadas. PHYSIS: Rev. Saúde Coletiva, Rio de Janeiro, v. 17, n.2, p. 343-352, 2007.

CARLINI,E.A.; GALDURÓZ,J.C.; NOTO,A.R.; NAPPO, S. A. I Levantamento Domiciliar Sobre o Uso de Drogas Psicotrópicas no Brasil - 2001. São Paulo: CEBRID - Centro Brasileiro de Informações sobre Drogas Psicotrópicas, 2002.

CESAR, B.A.L. Alcoolismo feminino: um estudo de suas peculiaridades. Jornal Brasileiro de Psiquiatria, v. 55, n.3, p. 208-11, 2006.

CORRADI-WEBSTER, C.M.; FURTADO, E.F. Papel dos Serviços de Saúde na Prevenção da Drogadição em Adolescentes de Risco Estudo de Caso. In: Anais do VII Ciclo de Estudos em Saúde Mental, Ribeirão Preto, p. 256-256, 1999.

; FIGUEROA, A.M.; FURTADO, E.F. Os Fatores de Risco e Avaliação da Gravidade do Uso de Substâncias Psicoativas em Adolescentes de Risco: uma discussão conceitual. In: Anais do III Fórum de Psiquiatria do Interior Paulista, Águas de Lindóia, v. 2. p. 23-23, 2000. 
;; LAPREGA, M. R.; FURTADO, E.F. Residentes em psiquiatria têm documentado problemas relacionados ao álcool em pacientes ambulatoriais? Revista de Psiquiatria do Rio Grande do Sul, v. 32, p. 01-05, 2009 (no prelo).

.; MINTO, EC; AQUINO, F.; ABADE, F.; YOSETAKE, L.L.; GORAYEB,R.; LAPREGA, M.R.; FURTADO, E.F. Capacitação de profissionais de Programa de Saúde da Família em estratégias de diagnóstico e intervenções breves para o uso problemático de álcool. Revista Eletrônica Saúde Mental Álcool e Drogas, v. 01, n. 1, p. 1-10, 2005.

.; LAPREGA, M.R.; FURTADO, E.F. Avaliação do desempenho do CAGE com pacientes psiquiátricos ambulatoriais. Revista Latino-Americana de Enfermagem, v. 13 , p. 1213-1218, 2005.

.; MORETTI-PIRES, R.O.; LUIS, M.A.V.; SILVA, E.C. Discursos e práticas sobre o uso problemático de álcool: grupo focal com enfermeiros. In: Encontro de Pesquisadores em Saúde Mental, 10., 2008, Ribeirão Preto, Programa e Resumos, Ribeirão Preto: FIERP, 2008. p.01.

.; ESPER, L.H.; PILLON, S.C. A enfermagem e a prevenção do uso indevido de drogas entre adolescentes. Acta Paulista de Enfermagem, v. 22, p. 331-334, 2009.

COYLE, A. Introduction to qualitative psychological research. In: LYONS, E.; COYLE, A. Analyzing qualitative data in psychology. London: Sage Publications, 2007. Cap.02, p.09-34.

DANTAS, R.O. Tempo de alcoolismo no desenvolvimento de doenças orgânicas em mulheres tratadas no Hospital das Clínicas de Ribeirão Preto, SP, Brasil. Revista de Saúde Pública, v. 19, p. 304-310, 1985.

DE SHAZER, S. Words are originally magic. New York: W.W. Norton \& Company, 1994. 285p.

EPSTON, D.; WHITE, M.; MURRAY, K. Proposta de uma terapia de reautoria: revisão da vida de Rose e comentário. In: MCNAMEE, S.; GERGEN, K.J. A terapia como construção social. Porto Alegre: Artes Médicas, 1998, pág. 117-139.

ETTORRE, E. Women and alcohol: a private pleasure or a public problem? London: The women's Press, 1997. 192p.

Revisioning women and drug use: gender, power and body. London: Palgrave Macmillan, 2007. 166p.

FONTANELLA, B.J.B. Procura de tratamento por dependentes de substâncias psicoativas: um estudo clínico qualitativo. 2000. 350f. Tese (Doutorado em Ciências Médicas) - Faculdade de Ciências Médicas, Universidade Estadual de Campinas, Campinas, 2000. 
FOUCAULT, M. Verdade e poder. In: FOUCAULT, M. Microfísica do Poder. 20a edição. São Paulo: Ed. Paz e Terra S/A, 2004. p. 1-14.

O nascimento da medicina social. In: FOUCAULT, M. Microfísica do Poder. 20a edição. São Paulo: Ed. Paz e Terra S/A, 2004. p. 1-14

FRANK, A.W. What is dialogical research, and why should we do it? Qualitative Health Research, v.15, n.7, p. 964-974, 2005.

FURTADO, E.F.; CORRADI, C.M.; FIGUEROA, A.M. PAI-PAD: Programa de Ações Integradas para Prevenção e Atenção ao Uso de Álcool e Drogas na Comunidade. Ribeirão Preto: FMRP-USP, 1999. 20p. Proposta de Programa.

Pesquisa e Avaliação sobre as Necessidades Assistenciais em Psiquiatria de Adolescentes. In: Anais da XXVII Reunião Anual de Psicologia da Sociedade Brasileira de Psicologia. Ribeirão Preto, 1997.

; CORRADI-WEBSTER, C.M.; LAPREGA， M.R. Implementing brief interventions for alcohol problems in the public health system in the region of Ribeirão Preto, Brazil, evaluation of the PAI-PAD model. Nordic Studies on Alcohol and Drugs, v. 25 , p. 539-551, 2008.

GERGEN, K.J. Realities and relationships: soundings in social construction. Cambridge: Harvard University Press, 1999.

GERGEN, K.J.; KAYE, J. Além da narrativa na negociação do sentido terapêutico. In: MCNAMEE, S.; GERGEN, K.J.A terapia como construção social. Porto Alegre: Ed. Artes Médicas, 1998.

13, n.2/3, p.362-378, 2007.

Relativism, religion, and relational being. Common Knowledge, $v$.

GERGEN, M.; GERGEN,K.J. The social construction of the real and the good. In: GERGEN, M.; GERGEN,K.J. Social construction: a reader. London: SAGE Publications LTD, 2003. Part 01, p.01-06.

GRACIA, T.I. O giro lingüístico. In: IÑIGUEZ I. Manual de análise do discurso em ciências sociais. Petrópolis: Ed. Vozes, 2004.

GRANDESSO, M.A. Sobre a reconstrução do significado: uma análise epistemológica e hermenêutica da prática clínica. São Paulo: Casa do Psicólogo, 2000. 422p.

GUANAES, C. A construção da mudança em terapia de grupo. São Paulo: Ed. Vetor, 2006. p.287. 
HARRÉ, R.; LANGENHOVE, L.V. Positioning Theory. United Kingdom (Oxford): Blackwell Publishers Ltd, 1999. 214p.

HAYNES, G.; DUNNAGAN, T.; CHRISTOPHER, S. Determinants of alcohol use in pregnant women at risk for alcohol consumption. Neurotoxicology and Teratology, v. 25, p. 659-66, 2003.

HERMANS H.J.M. A pessoa como narrador motivado de histórias: teoria da valoração e o método da autoconfrontação. In: GONÇALVES M.M.; GONÇALVES O.F. Psicoterapia, discurso e narrativa: a construção conversacional da mudança. $2^{a}$ Edição. Coimbra: Ed. Quarteto, 2007. Cap. 06, p.157-207.

HERNANDEZ-AVILA, C.A.; ROUNSAVILLE, B.J.; KRANZLER, H.R. Opioid-, cannabis- and alcohol-dependent women show more rapid progression to substance abuse treatment. Drug and Alcohol Dependence, v. 74, p.265-72, 2004.

HOCHGRAF, P.B.; ZILBERMAN, M.L.; ANDRADE, A. Women alcoholics-social, demographic and clinical characteristics in a Brazilian sample. Alcohol and Alcoholism, v. 30, n.4, p. 427-432, jul. 1995.

HOSKING, D.M.; MCNAMEE, S. Transforming Inquiry: Research as Relational Practice, 2009 (Book manuscript in preparation).

HUGHES, T.L.; JOHNSON, T.P.; WILSNACK, S.C.; SZALACHA, L.A. Childhood risk factors for alcohol abuse and psychological distress among adult lesbians. Child Abuse \& Neglect, v. 31, p.769-89, 2007.

IHRA - INTERNATIONAL HARM REDUCTION ASSOCIATION. What is harm reduction? Disponível em: http://www.ihra.net/Assets/2316/1/IHRA_HRStatement.pdf Acessado em: 09 de novembro de 2009.

\section{ILLICH, I. Health as one's own responsibility: No, thank you! 1990}

Fronteira, 1975.

A expropriação da saúde. Nêmesis da Medicina. Rio de Janeiro: Nova

IÑIGUEZ, L. Manual de análise do discurso em ciências sociais. Petrópolis: Ed. Vozes, 2004.

JENNISON, K.M.; JOHNSON, K.A. Parental alcoholism as a risk factor for DSM-IV defined alcohol abuse and dependence in American women: the protective benefits fo dyadic cohesion in marital communication. American Journal of Drug and Alcohol Abuse, v. 27, n.2, p. 349-374, 2001. 
KELLYA, A.B.; HALFORDB, W.K.; YOUNG, R.M. Expectations of the effects of drinking on couple relationship functioning: An assessment of women in distressed relationships who consume alcohol at harmful levels. Addictive Behaviors, v. 27, p. 451-464, 2002.

KERR-CORRÊA, F.; IGAMI, T.Z.; HIROCE, V.; TUCCI, A.M. Patterns of alcohol use between genders: A cross-cultural evaluation. Journal of Affective Disorders, v. 102, p.265-75, 2007.

KESSLER, R.C.; MCGONAGLE, K.A.; ZHAO, S.; NELSON, C.B.; HUGHES, M.; ESHLEMAN, S.; et al. Lifetime and 12-month prevalence of DSM-III-R psychiatric disorders in the United States. Archives of General Psychiatry, v. 51, p.8-19, 1994.

KINGA, A.C.; BERNARDY, N.C.; HAUNER, K. Stressful events, personality, and mood disturbance: Gender differences in alcoholics and problem drinkers. Addictive Behaviors, v. 28, p.171-187, 2003.

KUHN,T.S. On scientific paradigms. In: GERGEN, M.; GERGER,K.J. Social construction: a reader. London, 2003.

LARANJEIRA, R.; PINSKY, I.; ZALESKI, M. 10 Levantamento Nacional sobre Padrões de Consumo de Álcool na População Brasileira. Brasília: Secretaria Nacional Anti-Drogas. 2007.

LANGENHOVE, L.V.; HARRÉ, R. Positioning and the writing of science. In: LANGENHOVE, L.V.; HARRÉ, R. Positioning Theory. Oxford: Blackwell Publishers, 1999.

LIEBLICH, A.; TUVAL-MASHIACH, R.; ZILBER, T. Narrative research: reading, analysis and interpretation. California: SAGE Publications, 1998. p.187.

LYONS, E.; COYLE, A. Analysing qualitative data en psychology. London: SAGE Publication, 2007.

MACEDO, L.R.H.; CORRADI-WEBSTER, C.M.; FURTADO, E.F. Levantamento sobre Diagnósticos Relacionados ao Álcool em Pacientes Psiquiátricos Ambulatoriais.. In: Anais do XX Congresso Brasileiro de Psiquiatria. Florianópolis. p. 19-19, 2002.

MACHADO, C.; MATOS, M. Intervenção narrativa com um grupo de mulheres maltratadas - da desconstrução da posição de vítima à reconstrução de identidades preferenciais. In: GONÇALVES M.M.; GONÇALVES O.F. Psicoterapia, discurso e narrativa: a construção conversacional da mudança. 2a Edição. Coimbra: Ed. Quarteto, 2007. Cap.07., p. 209-234.

MACRAE, E. Aspectos socioculturais do uso de drogas e políticas de redução de danos. Disponível em: www.neip.info. Acesso em 25 de agosto de 2009. 
Abordagens qualitativas na compreensão do uso de psicoativos. In: Tavares, L.A , Almeida, AR. B.MacRAe, E.,Ferreira,O.S. et al (orgs.), Drogas: tempos, lugares e olhares sobre seu consumo. Salvador: EDUFBA; CEETAD/UFBA, 2004, p. 27-48.

Antropologia: Aspectos Sociais, Culturais e Ritualísticos. In: SEIBEL, S. D.; TOSCANO Jr.. A. Dependência de drogas. São Paulo: Editora Atheneu, 2001, p. 25-34.

SIMÕES, J.A. Prohibitionist drug policies and the subculture of cannabis use in two brazilian middle class urban settings. Disponível em: www.neip.info. Acesso em 10 de setembro de 2009.

MADRIGAL, E. Patrones de consumo y dependencia del alcohol y de sustancias psicoactivas en la mujer. In: ORGANIZAÇÃO PANAMERICANA DE LA SALUD. Genero, mujer y salud en las Americas. EUA, 1993, p.163-77.

MANCINELLI, R.; BINETTI, R.; CECCANTI, M. Woman, alcohol and environment: Emerging risks for health. Neuroscience and Biobehavioral Reviews, v. 31, p. 246$53,2007$.

MASTERS, C.; CARLSON, D.S. The process of reconnecting: recovery from the perspective of addicted women. Journal of Addictions Nursing, v.17, p. 205-210, 2006.

MCNAMEE, S. Therapy as social construction. In: STRONG, T.; PARE, D. Furthering talk: advances in the discursive therapies. New York: Kluwer Academic/Plenum Press, 2004. p.1-28.

; GERGEN, K. An invitation to relational responsibility. In: MCNAMEE, S.; GERGEN, K. Relational Responsibility. Thousand Oaks: Sage, 1998. cap. 01, p.03-28.

. The social construction of disorder - From pathology to potential. In: Draft for J.D. Raskin and S.K. Bridges (eds.). Studies in Meaning: Exploring Constructivist Psychology. New York: Pace University Press, 2002, p.1-18.

MERHY, E.E. Um ensaio sobre o médico e suas valises tecnológicas: contribuições para compreender as reestruturações produtivas do setor saúde. Interface Comunicação, Saúde, Educação, v. 4, n.6, p. 109-116, 2000.

MIDANIK, L.; ROOM, R. Contributions of social science to the alcohol field in an era of biomedicalization. Social Science \& Medicine, v.60, p.1107-1116, 2005.

MILLER, W.R.; ROLLNICK S. Entrevista Motivacional: preparando as pessoas para a mudança de comportamento adictivos. Porto Alegre: Ed. Artmed, 2001. $293 p$. 
MINTO, E.C.; CORRADI-WEBSTER, C.M.; GORAYEB,R.; LAPREGA,M.R.; FURTADO, E.F. Intervenções Breves para o uso abusivo de álcool em atenção primária. Epidemiologia e Serviços de Saúde, v. 16, p. 207-220, 2007

MÖLLER-LEIMKÜHLER, A.M. et al. Alcohol dependence and gender-role orientation. Eur Psychiatry, v. 17, p. 1-8, 2002.

MOOS, R.H.; MOOS, B.S.; TIMKO, C. Gender,treatment and self-help in remission from alcohol use disorders. Clinical Medicine \& Research, v. 4, n. 3, p. 163-174, 2006.

MOSCHETA, M. Dependência e generosidade. Disponível em: http://murilomoscheta.blogspot.com/ Acessado em: 10 de novembro de 2009.

NELSON-ZLUPKO L., DORE MM, KAUFFMAN E, KALTENBACH K. Women in Recovery Their Perceptions of Treatment Effectiveness. Journal of Substance Abuse Treatment, v. 13, n.1, p. 51-59, 1996.

NEVE, R.J. et al. Gender differences in drinking behavior in the Netherlands: convergence or stability? Addiction, v. 91, n.3, p. 357-373, mar.1996.

NEVES, A.N.A. As mulheres e os discursos genderizados sobre o amor: a caminho do "amor confluente" ou o retorno ao mito do "amor romântico"? Revista Estudos Feministas, v.15, n.3, p. 609-627, 2007.

NOGUEIRA, C. Análise(s) do discurso: diferentes concepções na prática de pesquisa em psicologia social. Psic.: Teor. e Pesq. v.24 no.2, pp. 235-242, 2008.

NOLEN-HOEKSEMA S. Gender differences in risk factors and consequences for alcohol use and problems. Clinical Psychology Review, v. 24, p. 981-1010, 2004.

.; HILT, L. Possible Contributors to the Gender Differences in Alcohol Use and Problems. The Journal of General Psychology, v.133, n.4, 357-374, 2006.

NUTT, D. Estimating drug harms: a risky business? Centre for Crime and Justice Studies. London, 2009.

OLIVEIRA, T.T.S.S.; CALDANA, R.H.L. Mães psicólogas ou psicólogas mães: vicissitudes na educação dos filhos. Estudos de Psicologia, v. 9, n.3, p. 585-593, 2004.

OLIVEIRA, Z.M.R.; GUANAES, C; COSTA, N.R.A. Discutindo o conceito de "jogos de papel": uma interface com a "teoria do posicionamento". In:ROSSETTI-FERREIRA, M.C. et al. Rede de Significações e o estudo do desenvolvimento humano. Porto Alegre: Artmed, 2004. Cap.3, p.69-80. 
PAI-PAD - PROGRAMA DE AÇÕES INTEGRADAS PARA PREVENÇÃO E ATENÇÃO DO USO DE DROGAS NA COMUNIDADE. Modalidades de treinamento. Disponível em: http://www.fmrp.usp.br/paipad/servicos/treinamento/modalidades_treiname nto.php. Acessado em: 26 de agosto de 2009.

PARLESAK, A.; BILLINGER, M.H.U.; BODE, C.; BODE, J.C; Gastric alcohol dehydrogenase activity in man influence of gender, age, alcohol consumption and smoking in a Caucasian population. Alcohol and Alcoholism, v. 37, n.4, p. 388-93, 2002.

PEGORARO, R.F.; CALDANA, R.H.L. Sofrimento psíquico em familiares de usuários de um Centro de Atenção Psicossocial (CAPS). Interface - Comunic., Saúde, Educ., v.12, n.25, p.295-307, 2008. Sobrecarga de familiares de usuários de um centro de atenção psicossocial. Psicologia em Estudo, Maringá, v. 11, n. 3, p. 569-577, 2006.

PICHOT, T.; SMOCK, S.A. Solution-focused substance abuse treatment. New York: Routledge, 2009, 232p.

PILLON, S. C.; LUIS, M.A.V. Modelos explicativos para o uso de álcool e drogas e a prática da enfermagem. Revista Latino-Americana de Enfermagem, v. 12, n.4, p. $676-82,2004$.

PINHEIRO, S.N.; LAPREGA, M.R.; FURTADO, E.F. Morbidade psiquiátrica e uso de álcool em gestantes usuárias do Sistema Único de Saúde. Revista de Saúde Pública, v.39, n.4, p. 593-8, 2005.

PINTO, J.P. Sobre discurso feminista em publicações: a política do Grupo Transas do Corpo. Estudos Feministas, v.12: 106-114, 2004

POTTER, J.; WETHERREL, M. Discourse and social psychology: beyond attitudes and behaviour. London: Sage Publication Ltd, 1987, 216p.

RASERA, E.F.; JAPUR M. Os sentidos da construção social: o convite construcionista para a psicologia. Paidéia ,v.15, n.30, p. 21-9, 2005.

Contribuições do pensamento construcionista para o estudo da prática grupal. Psicologia: Reflexão e Crítica, v. 14, n.1, p. 201-209, 2001.

ROSSETI-FERREIRA, M.C.; AMORIM, K. S.; SILVA, A.P.S. Rede de Significações: alguns conceitos básicos. In: ROSSETI-FERREIRA, M.C. et al. Rede de significações e o estudo do desenvolvimento humano. Porto Alegre: Ed. Artmed, 2004. Cap.01, p.2333.

ROXBURGH, S. Gender differences in the effect of job stressors on alcohol consumption. Addictive Behaviors, v.23, n.1, p.101-107, 1998. 
RUBIN, A.; STOUT, R.L.; LONGABAUGH, R. Gender differences in relapse situations. Addiction, v.91, p.111-120, dec.1996.

SILVA, A.P.S. Continuidades e descontinuidades de si na narrativa de homens que tiveram envolvimento com o crime. Ribeirão Preto, 2003. Tese (Doutorado) - Faculdade de Filosofia, Ciências e Letras de Ribeirão Preto, Universidade de São Paulo.

SIMÃO, M.O. et al. Alcoolismo feminino: revisão de aspectos relacionados à violência. Revista ABP-APAL, v.19, n.4, p.139-418, out./dez. 1997.

SOKOL, R.J.; CLARREN, S.K. Guidelines for use of terminology describing the impact of prenatal alcohol on the offspring. Alcohol Clin Exp Res, v. 13, n. 4, p. 597$598,1989$.

SOUZA, L.V.; SANTOS, M.A. A família e os transtornos alimentares. Medicina (Ribeirão Preto), v. 39, n.3, p. 403-409, jul/set. 2006.

SPINK, M.J. Práticas discursivas e produção de sentidos no cotidiano: aproximações teóricas e metodológicas. 3a ed., São Paulo: Ed. Cortez, 2004.

; LISBOA, M.S.; RIBEIRO, F.R.G. A construção do tabagismo como problema de Saúde Pública: uma confluência entre interesses políticos e processos de legitimação científica. Interface - Comunic., Saúde, Educ. v.13, n.29, p. 353-365, 2009.

SVIKIS, D.S. et al. Premenstrual symptomatology, alcohol consumption, and family history of alcoholism in women with premenstrual syndrome. Journal of Studies on Alcohol, v. 67, n. 6, p. 833-836, nov. 2006.

TAYLOR, S. Locating and conducting discourse analytic research. In: WETHERREL, M.; TAYLOR, S.; YATES, S. Discourse as data: a guide for analysis. 3a. edição. London: Sage Publications, 2008. Cap.01, p.05-48.

TESSER, C.D. Medicalização social (I): o excessivo sucesso do epistemicídio moderno na saúde. Interface - Comunic, Saúde, Educ, v.9, n.18, p.61-76, 2006.

TESTA, M. PARKS, K.A. The role of women's alcohol consumption in sexual victimization. Aggression and Violent Behavior, v. 1, n. 3, p. 217-234, 1996.

; LIVINGSTON, J.A.; HOFFMAN, J.H. Does sexual victimization predict subsequent alcohol consumption? A prospective study among a community sample of women. Addictive Behaviors, v. 32, p. 2926-39, 2007. 
TOLVANEN, E.; JYLHA, M. Alcohol in life story interviews with Finnish people aged 90 or over: Stories of gendered morality. Journal of Aging Studies, v. 19, p.419-435, 2005.

TOMM, K. Externalización del problema e interalización de la posición como agente. In: WHITE, M. Guias para uma terapia familiar sistemica. Barcelona; Editorial Gedisa, 1994.

TURATO, E.R. Métodos qualitativos e quantitativos na área da saúde: definições, diferenças e seus objetos de pesquisa. Revista Saúde Pública, v.39, n.3, p. 507-14, 2005.

VALENÇA, T. Drogas na cultura de consumo: do estigma ao preço da felicidade. In: Luis, M.A.V. (org.) Os novos velhos desafios da saúde mental. Ribeirão Preto: FIERP. p.183-191, 2008.

VAN TILBURGA, M.A.L.; VINGERHOETSB, A.J.J.M; The effects of alcohol on mood induced by an emotional: a study among women. Journal of Psychosomatic Research, v. 53, p. 805- 9, 2002.

VIEIRA, E.M. A medicalização do corpo feminino. Rio de Janeiro: Editora Fiocruz, 2002.

VINOGRADOV, S. ; YALON, I.D. Manual de psicoterapia de grupo. Porto Alegre, Editora Artes Médicas, 1992.

WALTON, C. Doing discourse analysis. Cap. 08.In: LYONS E, COYLE A. Analysing qualitative data en psychology. London: Sage Publications, 2007. Cap.08, p.117-144.

WHITE, M.; EPSTON, D. Medios narrativos para fines terapéuticos. Buenos Aires: Paidós, 1990. 222 p.

WILLIG, C. Introducing qualitative research in psychology: adventures in theory and method. New York: Open University Press, 2001.

WILSNACK, R.W. et al. Gender differences in alcohol consumption and adverse drinking consequences: cross-cultural patterns. Addiction, v. 95, n.2, p.251-265, feb. 2000.

WILSNACK, R. W.; WILSNACK, S. C.; OBOT, I. S. Why study gender, alcohol and culture? In: OBOT, I.S.; ROOM, R. (eds). Alcohol, Gender and Drinking Problems: Perspectives from Low and Middle Income Countries, Geneva: World Health Organization, pp. 1-23, 2005.

WITTGenstein, L. Philosophical Investigations. In: GeRGen, M.; GERGER,K.J. Social construction: a reader. London, 2003. 
WORLD HEALTH ORGANIZATION. Summary report of a World Health Organization meeting on dissemination of brief interventions for alcohol problems in primary health care: a strategy for developing countries. Alicante: WHO, 2002.20 p. Relatório de Reunião de Trabalho.

ZINBERG, N.E. Drug, Set, and Setting: The Basis for Controlled Intoxicant Use. Disponível em: http://www.druglibrary.org/schaffer/lsd/zinberg.htm Acessado em: 20 de setembro de 2009. 
Apêndice 



\title{
APÊNDICE 1
}

\section{TERMO DE CONSENTIMENTO LIVRE E ESCLARECIDO}

\section{Nome da Pesquisa: MULHERES E CONSUMO DE BEBIDAS ALCOÓlicAS: MUDANÇAS NO DECORRER DA VIDA}

\begin{abstract}
Algumas mulheres consomem bebidas alcoólicas de modo que Ihes preocupa e com isto, procuram um tratamento para este consumo. Sabemos que é difícil para a mulher procurar um tratamento para o uso de álcool. Nosso objetivo é conhecer como se dá o consumo de bebidas alcoólicas para a mulher ao longo de sua vida, levando-se em consideração os motivos que as levaram a começar a beber, os motivos pelas quais ela consumiu estas bebidas nos diversos momentos de sua vida e o por quê dela ter
\end{abstract} resolvido procurar tratamento.

Você está sendo convidada a participar deste estudo. Iremos te fazer algumas perguntas e pedimos a autorização para gravarmos esta conversa. Gostaríamos de esclarecer que: seu nome será mantido em sigilo; as informações que você nos der serão confidenciais e serão usadas apenas para este estudo podendo ser publicadas e/ou apresentadas com objetivo científico, entretanto, não será possível identificar as pessoas envolvidas no estudo. Sua participação é voluntária, sem nenhum tipo de pressão, isto é, a senhora não é obrigada a participar deste estudo e se desejar em qualquer momento não participar deste estudo, sua decisão será respeitada. Não há nenhum risco em participar deste estudo. Prevemos que para a realização da entrevista teremos um total de 1 a 3 encontros de 60 minutos de duração.

As informações que você nos der serão muito úteis para compreendermos melhor como se dá o consumo de álcool na vida de mulheres e com isto melhorar o planejamento dos serviços de saúde voltados a esta população.

Esses são seus direitos ao participar da pesquisa (Resolução 196/96 do Conselho Nacional de Saúde/ Ministério da Saúde)

1. A garantia de receber a resposta a qualquer pergunta ou esclarecimento a qualquer dúvida acerca dos procedimentos, riscos, benefícios e outros relacionados com a pesquisa a que será submetido;

2. A liberdade de retirar o seu consentimento a qualquer momento e deixar de participar no estudo, sem que isso traga prejuízo à continuação de seu atendimento e tratamento habitual nesse serviço;

3. A segurança de não ser identificado e do caráter confidencial de toda informação relacionada com sua privacidade;

4. O compromisso de receber informação atualizada durante o estudo, mesmo que esta afete sua vontade de continuar participando;

5. A disponibilidade de tratamento médico e indenização a que legalmente tem direito, por parte da instituição de saúde, em caso de danos justificados, causados diretamente pela pesquisa;

6. Se existirem gastos adicionais, estes serão absorvidos pelo orçamento da pesquisa.

Considerando as questões acima: 
$\mathrm{Eu}$,

RG: abaixo assinado,

tendo recebidos as informações sobre a pesquisa e sobre meus direitos acima relacionados, declaro estar ciente e devidamente esclarecido e de que consinto em participar do estudo.

Ribeirão Preto, 1

Assinatura do participante da pesquisa:

Se precisar de algum outro tipo de esclarecimento sobre o estudo, você pode entrar em contato com os pesquisadores responsáveis:

Clarissa Mendonça Corradi-Webster Fone para contato: (16) 36024408

(Psicóloga da Escola de Enfermagem de Email: clarissac@usp.br

Ribeirão Preto - USP)

CRP: 06/53151-5

Ana Maria Pimenta Carvalho Fone para contato: (16) 36023427

(Profa. da Escola de Enfermagem de Email:anacar@eerp.usp.br

Ribeirão Preto - USP)

CRP: $06 / 4826$

Erikson Felipe Furtado

Fone para contato: (16) 36022727

(Prof. Faculdade de Medicina de Ribeirão Email: efurtado@fmrp.usp.br Preto - USP)

CRM: SP 82645 



\section{ANEXO}
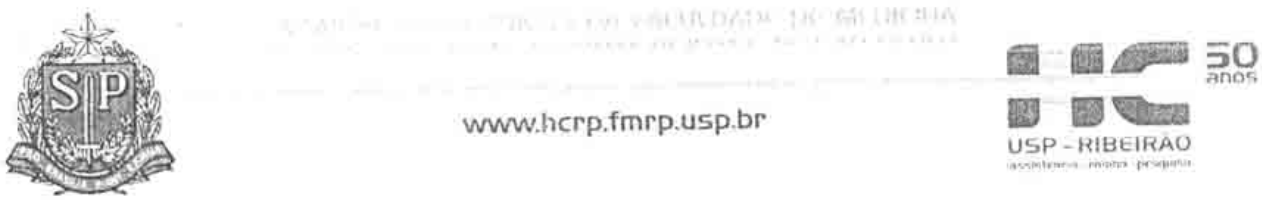

Ribeirāo Preto, 10 de janeiro de 2007

Oficio $\mathrm{n}^{\circ} 82 / 2007$

$\mathrm{CEP} / \mathrm{SPC}$

Prezada Senhora,

O trabalho intitulado "DEPENDÊNCIA DE ÁLCOOL:

CONSTRUÇÃO DO PROBLEMA NA VIDA DE MULHERES”, foi analisado e APROVADO "AD REFERENDUM", bem como o Termo de Consentimento Livre e Esclarecido, de acordo com o Processo HCRP n ${ }^{\circ} 13420 / 2006$.

Atenciosamente.

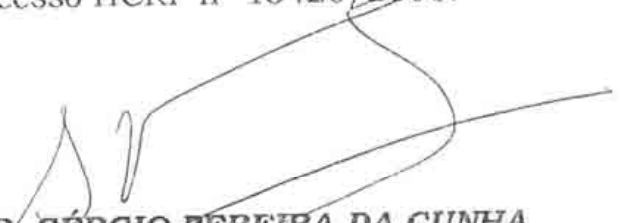

PROF. DR. SÉRGIO PEREIRA DA CUNHA

Coordenador do Comitê de Ética em

Pesquisa do HCRP e da FMRP-USP

llustrissima Senhora

CLARISSA MENDONÇA CORRADI WEBSTER

PROF $^{a}$ DR $^{a}$ AINA MARIA PINENTA CARVALHO (Orientadora)

Escola de Enfermagem de Ribeirão Preto-USP

Depto. de Enfermagem Psiquiâtrica e Ciências Humanas 
